\title{
AVALIAÇÃO DE MÉTODOS PARA DESINFECÇÃO DE ÁGUA, EMPREGANDO CLORO, ÁCIDO PERACÉTICO, OZÔNIO E O PROCESSO DE DESINFECÇÃO COMBINADO OZÔNIO/CLORO.
}

JEANETTE BEBER DE SOUZA

Tese apresentada à Escola de Engenharia de São Carlos, da Universidade de São Paulo, como parte dos requisitos para a obtenção do Título de Doutor em Hidráulica e Saneamento.

Orientador: Prof.Dr Luiz Antonio Daniel

São Carlos - SP

2006 


\section{AGRADECIMENTOS}

Especialmente ao professor Luiz Antonio Daniel exprimo minha apreciação por seu profissionalismo, dedicação à pesquisa, incondicional paciência e simpatia. E, principalmente, agradeço por todos os anos de amigável e valiosa orientação.

Aos amados pais Diva e Antonio que mesmo estando longe, há tantos anos, encontram-se sempre presentes em todos os momentos.

Às queridas irmãs Marta Cristina, Cecília e Rosália e aos lindos sobrinhos: Îsis, Bruna, Tainã e Livia.

Aos tios Vivi, Ebes e Tide que tiveram grande influência em minha vida.

Aos caros e inesquecíveis amigos Luci Sartori, Rodrigo Moruzzi, Renata Moretti, André e Ana Flávia de Oliveira, Marcelo Barroso, Valmir Moraes, Hélio Rodrigues, Adelena Gonçalves Maia e Celane Nery.

Especialmente agradeço à Ivete Vasconcelos Lopes Ferreira pelo companheirismo nas longas horas de laboratório, inúmeros favores prestados, e principalmente pela sincera amizade construída. Guardarei imensa saudade.

Júlio César Trofino, Ana Paula Paim, Elizabeth de Matos Moraes e Maria Ângela Talarico Adorno pelo enorme auxilio prestado em análises de laboratório durante a etapa experimental da pesquisa, profissionalismo e simpatia.

Paulo, Cidinha, Pavi, Sá e Rose pela atenção e simpatia.

Aos professores, funcionários e demais colegas do Departamento de Hidráulica e Saneamento.

Aos professores, funcionários e acadêmicos do Centro de Ciências Agrárias e Ambientais da Universidade Estadual do Centro-Oeste (CAA/UNICENTRO) pelo apoio e colaboração, especialmente ao professor Antônio José de Araújo.

Ao CNPq pela concessão da bolsa de Doutorado. 
Aos meus amados companheiros de todas as horas, Cacá e Pedro. 


\section{SUMÁRIO}

\begin{tabular}{|c|c|}
\hline TóP & PÁGINA \\
\hline LISTA DE FIGURAS & i \\
\hline LISTA DE TABELAS & iv \\
\hline RESUMO & viii \\
\hline ABSTRACT & ix \\
\hline 1- INTRODUÇÃO & 1 \\
\hline 2- OBJETIVOS & 7 \\
\hline 3- REVISÃO DA LITERATURA & 8 \\
\hline $\begin{array}{l}3.1 \text { - Doenças de transmissão hídrica - Patogênicos clássicos e } \\
\text { emergentes }\end{array}$ & 8 \\
\hline $\begin{array}{l}3.2-\text { Desinfecção de água de abastecimento }- \text { Mudança de } \\
\text { paradigma }\end{array}$ & 12 \\
\hline 3.3 - Microrganismos indicadores. & 17 \\
\hline 3.3.1 - Coliformes fecais e Escherichia coli & 21 \\
\hline 3.3.2 - Colifagos & 22 \\
\hline 3.3.3-Clostridium perfringens & 25 \\
\hline 3.4 - Os desinfetantes empregados na pesquisa de Doutorado & 27 \\
\hline 3.4.1 - Mecanismo de ação dos desinfetantes & 27 \\
\hline $\begin{array}{l}\text { 3.4.2 - Inativação de patogênicos e eficácia da desinfecção com } \\
\text { cloro, ácido peracético e ozônio }\end{array}$ & 31 \\
\hline 3.4.3 - Subprodutos da desinfecção & 40 \\
\hline 3.4.4 - Processos combinados de desinfecção & 47 \\
\hline 3.4.4.1 - Subprodutos associados aos processos combinados & 52 \\
\hline 4 - MATERIAL E MÉTODOS & 59 \\
\hline 4.1 - Considerações iniciais & 59 \\
\hline 4.2 - Água de estudo & 59 \\
\hline $\begin{array}{l}4.3 \text { - Cultivo, preservação e quantificação dos microrganismos } \\
\text { indicadores }\end{array}$ & 61 \\
\hline 4.3.1-E. coli & 62 \\
\hline 4.3.1.1 - Quantificação de E. coli & 63 \\
\hline 4.3.2 - Colifagos & 65 \\
\hline 4.3.2.1 - Quantificação dos colifagos & 66 \\
\hline 4.3.3 - C. perfringens & 68 \\
\hline 4.3.3.1 - Quantificação de C. perfringens & 71 \\
\hline $\begin{array}{l}4.4 \text { - Separação das células dos microrganismos dos meios de } \\
\text { cultura }\end{array}$ & 72 \\
\hline 4.5 - Desinfecção com cloro & 72 \\
\hline 4.5.1 - Cloro residual & 73 \\
\hline 4.6 - Desinfecção com ácido peracético & 74 \\
\hline 4.6.1 - Ácido peracético residual & 75 \\
\hline 4.7 - Desinfecção com ozônio & 75 \\
\hline
\end{tabular}


4.7.1 - Ozônio residual

4.8 - Desinfecção Seqüencial: ozônio / cloro

79

79

4.9 - Métodos analíticos, exames, análises físico-químicas e equipamentos

4.9.1 - Carbono orgânico dissolvido (COD) e Absorbância UV$254 \mathrm{~nm}$

4.9.2 - Análises de THM

4.9.3 - Métodos analíticos e equipamentos

80

- RESULTADOS E DISCUSSÃO

5.1 - Desinfecção com cloro

5.1.1 - Inativação de E. coli, colifagos e C. perfringens

5.1.2 - Consumo de cloro

5.1.3 - Carbono Orgânico Dissolvido (COD) e Absorbância UV$254 \mathrm{~nm}$

5.1.4 - Ensaios com cloro para água isenta dos meios de cultura

5.1.5 - Monitoramento de THMs na água de estudo após desinfecção com cloro

5.2 - Desinfecção com ácido peracético

5.2.1 - Inativação de E. coli, colifagos e C. perfringens com ácido peracético

5.2.2 - Influência das características da água de estudo

5.23 - Carbono Orgânico Dissolvido (COD) e Absorbância UV$254 \mathrm{~nm}$

5.3 - Desinfecção com ozônio

5.3.1 - Produção de ozônio

5.3.2 - Inativação de E. coli, colifagos e C. perfringens com ozônio

5.3.3 - Influência das características da água de estudo

5.3.4 - Carbono Orgânico Dissolvido (COD) e Absorbância UV$254 \mathrm{~nm}$

5.4 - Desinfecção combinada: ozônio/ cloro

5.4.1 - Verificação de sinergismo

80

80

81

83

83

83

92

98

5.4.2 - Uso de sinergismo em critérios de projeto

6 - CONCLUSÕES

7 - SUGESTÕES

102

106

109

109

118

119

121

121

122

8 - REFERÊNCIAS BIBLIOGRÁFICAS

ANEXOS

131

132

135

146

149

151

155

156

163




\section{LISTA DE FIGURAS}

TóPICo

PÁGINA

\begin{tabular}{l|c}
\hline Figura 3.1 - Caricatura de Prey - 'A sopa de monstros'. & 9 \\
\hline Figura 4.1 - Foto do equipamento de agitação da água. & 60 \\
\hline Figura 4.2 - Foto do aparelho de radiação UV. & 60 \\
\hline Figura 4.3 - Colônias de coliformes totais e E. coli em placa de Petri. & 64 \\
\hline Figura 4.4 - Placas inoculadas com diferentes tipos de colifagos. & 67 \\
\hline $\begin{array}{l}\text { Figura 4.5 - Jarra de anaerobiose usada para cultivo de C. } \\
\text { perfringens. }\end{array}$ & 70 \\
\hline $\begin{array}{l}\text { Figura 4.6 - Esquema da unidade piloto de ozonização } \\
\text { Figura 5.1 - Inativação de E. coli, colifagos e C. perfringens para 2,0 } \\
\text { mg/L de cloro aplicado (cor baixa). }\end{array}$ & 86 \\
\hline $\begin{array}{l}\text { Figura 5.2 - Inativação de E. coli, colifagos e C. perfringens para 3,0 } \\
\text { mg/L de cloro aplicado (cor baixa). }\end{array}$ & 86 \\
\hline $\begin{array}{l}\text { Figura 5.3 - Inativação de E. coli, colifagos e C. perfringens para 4,0 } \\
\text { mg/L de cloro aplicado (cor baixa). }\end{array}$ & 87 \\
\hline
\end{tabular}

Figura 5.4 - Inativação de E. coli, colifagos e C. perfringens para 5,0 $\mathrm{mg} / \mathrm{L}$ de cloro aplicado (cor baixa).

Figura 5.5 - Inativação de E. coli, colifagos e C. perfringens para 2,0 $\mathrm{mg} / \mathrm{L}$ de cloro aplicado (cor elevada).

Figura 5.6 - Inativação de E. coli, colifagos e C. perfringens para 3,0 $\mathrm{mg} / \mathrm{L}$ de cloro aplicado (cor elevada).

87

Figura 5.7 - Inativação de E. coli, colifagos e C. perfringens para 4,0 $\mathrm{mg} / \mathrm{L}$ de cloro aplicado (cor elevada).

Figura 5.8 - Inativação de E. coli, colifagos e C. perfringens para 5,0 $\mathrm{mg} / \mathrm{L}$ de cloro aplicado (cor elevada).

Figura 5.9 - Cloro residual livre e total em função do tempo de contato, para 2,0 mg/L de cloro aplicado (água cor baixa).

Figura 5.10 - Cloro residual livre e total em função do tempo de contato, para 3,0 mg/L de cloro aplicado (água cor baixa).

Figura 5.11 - Cloro residual livre e total em função do tempo de contato, para 4,0 mg/L de cloro aplicado (água cor baixa).

Figura 5.12 - Cloro residual livre e total em função do tempo de contato, para $5,0 \mathrm{mg} / \mathrm{L}$ de cloro aplicado (água cor baixa).

Figura 5.13 - Cloro residual livre e total em função do tempo de contato, para $2,0 \mathrm{mg} / \mathrm{L}$ de cloro aplicado (água cor elevada).

Figura 5.14 - Cloro residual livre e total em função do tempo de contato, para 3,0 mg/L de cloro aplicado (água cor elevada).

Figura 5.15 - Cloro residual livre e total em função do tempo de contato, para 4,0 mg/L de cloro aplicado (água cor elevada).

Figura 5.16 - Cloro residual livre e total em função do tempo de contato, para 5,0 mg/L de cloro aplicado (água cor elevada).

Figura 5.17 - Variação da concentração de Clorofórmio para as concentrações de cloro aplicadas de 2,0; 3,0; 4,0 e 5,0 mg/L.

88

88

89

89

94

94

95

95

96

96

97

97

107 
Figura 5.18 - Inativação de E. coli, colifagos e C. perfringens para 2,0 $\mathrm{mg} / \mathrm{L}$ de ácido peracético aplicado (cor baixa).

112

Figura 5.19 - Inativação de E. coli, colifagos e C. perfringens para 3,0 $\mathrm{mg} / \mathrm{L}$ de ácido peracético aplicado (cor baixa).

Figura 5.20 - Inativação de E. coli, colifagos e C. perfringens para 4,0 $\mathrm{mg} / \mathrm{L}$ de ácido peracético aplicado (cor baixa).

Figura 5.21 - Inativação de E. coli, colifagos e C. perfringens para 5,0 $\mathrm{mg} / \mathrm{L}$ de ácido peracético aplicado (cor baixa).

Figura 5.22 - Inativação de E. coli, colifagos e C. perfringens para 2,0 $\mathrm{mg} / \mathrm{L}$ de ácido peracético aplicado (cor elevada).

Figura 5.23 - Inativação de E. coli, colifagos e C. perfringens para 3,0 $\mathrm{mg} / \mathrm{L}$ de ácido peracético aplicado (cor elevada).

Figura 5.24 - Inativação de E. coli, colifagos e C. perfringens para 4,0 $\mathrm{mg} / \mathrm{L}$ de ácido peracético aplicado (cor elevada).

Figura 5.25 - Inativação de E. coli, colifagos e C. perfringens para 5,0 $\mathrm{mg} / \mathrm{L}$ de ácido peracético aplicado (cor elevada).

112

Figura 5.26 - Produção de ozônio do equipamento Qualid'or em relação à vazão de oxigênio

Figura 5.27- Inativação de E. coli, colifagos e C. perfringens para 2,0 $\mathrm{mg} / \mathrm{L}$ de ozônio aplicado (cor baixa).

Figura 5.28- Inativação de E. coli, colifagos e C. perfringens para 3,0 $\mathrm{mg} / \mathrm{L}$ de ozônio aplicado (cor baixa).

113

113

Figura 5.29- Inativação de E. coli, colifagos e C. perfringens para 4,0 $\mathrm{mg} / \mathrm{L}$ de ozônio aplicado (cor baixa).

Figura 5.30- Inativação de E. coli, colifagos e C. perfringens para 5,0 $\mathrm{mg} / \mathrm{L}$ de ozônio aplicado (cor baixa).

Figura 5.31 - Inativação de E. coli, colifagos e C. perfringens para 2,0 mg/L de ozônio aplicado (cor elevada).

Figura 5.32- Inativação de E. coli, colifagos e C. perfringens para 3,0 $\mathrm{mg} / \mathrm{L}$ de ozônio aplicado (cor elevada).

114

114

115

Figura 5.33- Inativação de E. coli, colifagos e C. perfringens para 4,0 $\mathrm{mg} / \mathrm{L}$ de ozônio aplicado (cor elevada).

115

Figura 5.34- Inativação de E. coli, colifagos e C. perfringens para 5,0 $\mathrm{mg} / \mathrm{L}$ de ozônio aplicado (cor elevada).

Figura 5.35 - Inativação de E. coli com os processos individuais, ozônio $2,0 \mathrm{mg} / \mathrm{L}$, cloro $2,0 \mathrm{mg} / \mathrm{L}$ e com o processo combinado $2 \mathrm{O}_{3}+$ $2 \mathrm{Cl}_{2} \mathrm{mg} / \mathrm{L}$.

Figura 5.36 - Inativação de E. coli com os processos individuais, ozônio $3,0 \mathrm{mg} / \mathrm{L}$, cloro $2,0 \mathrm{mg} / \mathrm{L}$ e com o processo combinado $3 \mathrm{O}_{3}+$ $2 \mathrm{Cl}_{2} \mathrm{mg} / \mathrm{L}$.

Figura 5.37 - Inativação de E. coli com os processos individuais, ozônio $5,0 \mathrm{mg} / \mathrm{L}$, cloro $2,0 \mathrm{mg} / \mathrm{L}$ e com o processo combinado $5 \mathrm{O}_{3}+$ 122

125

125

126

126 $2 \mathrm{Cl}_{2} \mathrm{mg} / \mathrm{L}$.

Figura 5.38 - Inativação de E. coli com os processos individuais, ozônio $2,0 \mathrm{mg} / \mathrm{L}$, cloro $5,0 \mathrm{mg} / \mathrm{L}$ e com o processo combinado $2 \mathrm{O}_{3}+$ 128 $5 \mathrm{Cl}_{2} \mathrm{mg} / \mathrm{L}$.

Figura 5.39 - Inativação de E. coli com os processos individuais, 
ozônio $2,0 \mathrm{mg} / \mathrm{L}$, cloro $2,0 \mathrm{mg} / \mathrm{L}$ e com o processo combinado $2 \mathrm{O}_{3}+$ $2 \mathrm{Cl}_{2} \mathrm{mg} / \mathrm{L}$.

Figura 5.40 - Inativação de colifagos com os processos individuais, ozônio $3,0 \mathrm{mg} / \mathrm{L}$, cloro $2,0 \mathrm{mg} / \mathrm{L}$ e com o processo combinado $3 \mathrm{O}_{3}+$ 141 $2 \mathrm{Cl}_{2} \mathrm{mg} / \mathrm{L}$.

Figura 5.41 - Inativação de colifagos com os processos individuais, ozônio $5,0 \mathrm{mg} / \mathrm{L}$, cloro $2,0 \mathrm{mg} / \mathrm{L}$ e com o processo combinado $5 \mathrm{O}_{3}+$ $2 \mathrm{Cl}_{2} \mathrm{mg} / \mathrm{L}$.

Figura 5.42 - Inativação de colifagos com os processos individuais, ozônio $2,0 \mathrm{mg} / \mathrm{L}$, cloro $5,0 \mathrm{mg} / \mathrm{L}$ e com o processo combinado $2 \mathrm{O}_{3}+$ $5 \mathrm{Cl}_{2} \mathrm{mg} / \mathrm{L}$.

Figura 5.43 - Inativação de $C$. perfringens com os processos individuais, ozônio $2,0 \mathrm{mg} / \mathrm{L}$, cloro $2,0 \mathrm{mg} / \mathrm{L}$ e com o processo combinado $2 \mathrm{O}_{3}+2 \mathrm{Cl}_{2} \mathrm{mg} / \mathrm{L}$.

Figura 5.44- Inativação de C. perfringens com os processos individuais, ozônio $3,0 \mathrm{mg} / \mathrm{L}$, cloro $2,0 \mathrm{mg} / \mathrm{L}$ e com o processo combinado $3 \mathrm{O}_{3}+2 \mathrm{Cl}_{2} \mathrm{mg} / \mathrm{L}$.

Figura 5.45- Inativação de C. perfringens com os processos individuais, ozônio $5,0 \mathrm{mg} / \mathrm{L}$, cloro $2,0 \mathrm{mg} / \mathrm{L}$ e com o processo combinado $5 \mathrm{O}_{3}+2 \mathrm{Cl}_{2} \mathrm{mg} / \mathrm{L}$.

Figura 5.46- Inativação de $C$. perfringens com os processos individuais, ozônio $2,0 \mathrm{mg} / \mathrm{L}$, cloro $5,0 \mathrm{mg} / \mathrm{L}$ e com o processo combinado $2 \mathrm{O}_{3}+5 \mathrm{Cl}_{2} \mathrm{mg} / \mathrm{L}$. 


\section{LISTA DE TABELAS}

TÓPICO

PÁGINA

Tabela 3.1 - Principais doenças causadas por patogênicos veiculados pela água.

11

Tabela 3.2 - Principais microrganismos indicadores de contaminação fecal.

19

Tabela 3.3 - Microrganismos indicadores de processo, indicadores fecais e organismo índice.

Tabela 3.4 - Dados comparativos de CT para 99\% de inativação de diversos organismos com ozônio e cloro.

Tabela 3.5 - Resumo dos valores de CT para inativação de 99\% de oocistos de Cryptosporidium com ozônio.

Tabela 3.6 - SPDs identificados por cromatografia gasosa e espectrometria de massa na água desinfetada com $\mathrm{NaClO}, \mathrm{ClO}_{2}$ e APA.

Tabela 3.7 - Efeitos sinergísticos observados com os processos combinados.

Tabela 3.8 - Subprodutos associados a processos de oxidação/ desinfecção combinados.

Tabela 4.1 - Informações referentes à cepa de E. coli ATCC 11229.

Tabela 4.2 - Composição do meio TSB.

Tabela 4.3 - Composição do meio TSA modificado.

Tabela 4.4 - Informações referentes à bactéria C. perfringens ATCC 13124.

Tabela 4.5 - Composição do meio DRCM.

Tabela 4.6 - Métodos analíticos, exames, análises e equipamentos empregados durante os ensaios de desinfecção.

Tabela 5.1 - Inativação de E. coli, colifagos e C. perfringens em função do tempo de contato e concentração residual de cloro para água de estudo com cor baixa.

Tabela 5.2 - Inativação de E. coli, colifagos e C. perfringens em função do tempo de contato e concentração residual de cloro para água de estudo com cor elevada.

Tabela 5.3 - Análises de COD e Abs UV 254 nm para desinfecção com cloro (água com cor baixa).

Tabela 5.4 - Análises de COD e Abs UV 254 nm para desinfecção com cloro (água com cor elevada).

Tabela 5.5 - Inativação de E. coli, colifagos e C. perfringens em função do tempo de contato e concentração residual de cloro livre para água de estudo.

20

37

39

44

50

53

62

63

66

69

69

82

84

85

99

99

103 
Tabela 5.6 - Análises de COD e Abs UV 254 nm para desinfecção com cloro e água isenta dos meios de cultura.

105

Tabela 5.7 - Inativação de $E$. coli, colifagos e C. perfringens em função do tempo de contato e concentração residual de ácido peracético para água de estudo com cor baixa.

110

Tabela 5.8 - Inativação de E. coli, colifagos e C. perfringens em função do tempo de contato e concentração residual de ácido peracético para água de estudo com cor elevada.

Tabela 5.9 - Análises de COD e Abs UV $254 \mathrm{~nm}$ para desinfecção com ácido peracético para água com cor baixa.

Tabela 5.10 - Análises de COD e Abs UV $254 \mathrm{~nm}$ para desinfecção com ácido peracético para água com cor elevada.

Tabela 5.11 - Produção de ozônio para diferentes vazões de oxigênio utilizando o método iodométrico.

111

Tabela 5.12 - Inativação de E. coli, colifagos e C. perfringens em função do tempo de contato e concentração efetiva de ozônio para água de estudo com cor baixa.

Tabela 5.13 - Inativação de E. coli, colifagos e C. perfringens em função do tempo de contato e concentração residual de ácido peracético para água de estudo com cor elevada.

Tabela 5.14 - Análises de COD e Abs UV 254 nm para desinfecção com ozônio para água com cor baixa.

Tabela 5.15 - Análises de COD e Abs UV $254 \mathrm{~nm}$ para desinfecção com ozônio para água com cor elevada.

Tabela 5.16 - Combinações dos desinfetantes $\mathrm{O}_{3}$ e $\mathrm{Cl}_{2}$

119

Tabela 5.17 - Inativação de E. coli empregando o processo combinado $\mathrm{O}_{3} / \mathrm{Cl}_{2}$.

Tabela 5.18 - Inativação de colifagos empregando o processo combinado $\mathrm{O}_{3} / \mathrm{Cl}_{2}$.

Tabela 5.19 - Inativação de C. perfringens empregando o processo combinado $\mathrm{O}_{3} / \mathrm{Cl}_{2}$.

Tabela 5.20 - Verificação de sinergismo empregando o processo combinado $\mathrm{O}_{3} / \mathrm{Cl}_{2}$.

ANEXOS

TABELA A 01- Características da água de estudo bruta (cor baixa) e das amostras após a desinfecção com cloro aplicado em concentração de $2,0 \mathrm{mg} / \mathrm{L}$.

TABELA A 02- Características da água de estudo bruta (cor baixa) e das amostras após a desinfecção com cloro aplicado em concentração de 3,0 mg/L.

TABELA A 03 - Características da água de estudo bruta (cor baixa) e das amostras após a desinfecção com cloro aplicado em concentração 4,0 mg/L.

TABELA A 04 - Características da água de estudo bruta (cor baixa) e das amostras após a desinfecção com cloro aplicado em 124 concentração de 5,0 mg/L. 
TABELA A 05 - Características da água de estudo bruta (cor elevada) e das amostras após a desinfecção com cloro aplicado em concentração de $2,0 \mathrm{mg} / \mathrm{L}$.

TABELA A 06 - Características da água de estudo bruta (cor elevada) e das amostras após a desinfecção com cloro aplicado em concentração de 3,0 mg/L .

TABELA A 07 - Características da água de estudo bruta (cor elevada) e das amostras após a desinfecção com cloro aplicado em concentração de 4,0 mg/L .

TABELA A 08 - Características da água de estudo bruta (cor elevada) e das amostras após a desinfecção com cloro aplicado em concentração de 5,0 mg/L .

TABELA A 09 - Características da água de estudo bruta sem meio de cultura e das amostras após desinfecção com cloro aplicado em concentração de 2,0 mg/L .

TABELA A 10 - Características da água de estudo bruta (cor baixa) e das amostras após a desinfecção com ácido peracético aplicado em concentração $2,0 \mathrm{mg} / \mathrm{L}$.

TABELA A 11 - Características da água de estudo bruta (cor baixa) e das amostras após a desinfecção com ácido peracético aplicado em concentração $3,0 \mathrm{mg} / \mathrm{L}$.

165

TABELA A 12 - Características da água de estudo bruta (cor baixa) e das amostras após a desinfecção com ácido peracético aplicado em concentração 4,0 mg/L.

TABELA A 13 - Características da água de estudo bruta (cor baixa) e das amostras após a desinfecção com ácido peracético aplicado em concentração $5,0 \mathrm{mg} / \mathrm{L}$.

TABELA A 14 - Características da água de estudo bruta (cor elevada) e das amostras após a desinfecção com ácido peracético aplicado em concentração $2,0 \mathrm{mg} / \mathrm{L}$.

TABELA A 15 - Características da água de estudo bruta (cor elevada) e das amostras após a desinfecção com ácido peracético aplicado em concentração $3,0 \mathrm{mg} / \mathrm{L}$.

TABELA A 16 - Características da água de estudo bruta (cor elevada) e das amostras após a desinfecção com ácido peracético aplicado em concentração 4,0 mg/L.

TABELA A 17 - Características da água de estudo bruta (cor elevada) e das amostras após a desinfecção com ácido peracético aplicado em concentração $5,0 \mathrm{mg} / \mathrm{L}$.

TABELA A 18 - Características da água de estudo bruta (cor baixa) e das amostras após a desinfecção com ozônio aplicado em concentração $2,0 \mathrm{mg} / \mathrm{L}$.

TABELA A 19 - Características da água de estudo bruta (cor baixa) e das amostras após a desinfecção com ozônio aplicado em concentração 3,0 mg/L. 


\begin{tabular}{|c|c|}
\hline $\begin{array}{l}\text { TABELA A } 20 \text { - Características da água de estudo bruta (cor baixa) e } \\
\text { das amostras após a desinfecção com ozônio aplicado em } \\
\text { concentração 4,0 mg/L. }\end{array}$ & 172 \\
\hline $\begin{array}{l}\text { TABELA A } 21 \text { - Características da água de estudo bruta (cor baixa) e } \\
\text { das amostras após a desinfecção com ozônio aplicado em } \\
\text { concentração } 5,0 \mathrm{mg} / \mathrm{L} \text {. }\end{array}$ & 173 \\
\hline $\begin{array}{l}\text { TABELA A } 22 \text { - Características da água de estudo bruta (cor elevada) } \\
\text { e das amostras após a desinfecção com ozônio aplicado em } \\
\text { concentração } 2,0 \mathrm{mg} / \mathrm{L} \text {. }\end{array}$ & 173 \\
\hline $\begin{array}{l}\text { TABELA A } 23 \text { - Características da água de estudo bruta (cor elevada) } \\
\text { e das amostras após a desinfecção com ozônio aplicado em } \\
\text { concentração 3,0 mg/L. }\end{array}$ & 174 \\
\hline $\begin{array}{l}\text { TABELA A } 24 \text { - Características da água de estudo bruta (cor elevada) } \\
\text { e das amostras após a desinfecção com ozônio aplicado em } \\
\text { concentração } 4,0 \mathrm{mg} / \mathrm{L} \text {. }\end{array}$ & 174 \\
\hline $\begin{array}{l}\text { TABELA A } 25 \text { - Características da água de estudo bruta (cor elevada) } \\
\text { e das amostras após a desinfecção com ozônio aplicado em } \\
\text { concentração } 5,0 \mathrm{mg} / \mathrm{L} \text {. }\end{array}$ & 175 \\
\hline $\begin{array}{l}\text { TABELA A } 26-\text { Número final }(\mathrm{N}) \text { de } E \text {. coli para o processo } \\
\text { combinado } \mathrm{O}_{3} / \mathrm{Cl}_{2} \text {. O número inicial de } E \text {. coli foi de No }=1,0 \times 10^{8} \\
\text { UFC } / 100 \mathrm{~mL} \text {. }\end{array}$ & 175 \\
\hline $\begin{array}{l}\text { TABELA A } 27-\text { Número final }(\mathrm{N}) \text { de colifagos para o processo } \\
\text { combinado } \mathrm{O}_{3} / \mathrm{Cl}_{2} \text {. O número inicial de colifagos foi de No }=2,0 \times 10^{7} \\
\text { UFP } / 100 \mathrm{~mL} \text {. }\end{array}$ & 176 \\
\hline $\begin{array}{l}\text { TABELA A } 28-\text { Número final }(\mathrm{N}) \text { de } C \text {. perfringens de para o processo } \\
\text { combinado } \mathrm{O}_{3} / \mathrm{Cl}_{2} \text {. O número inicial de } C \text {. perfringens foi de No = } \\
1,0 \times 10^{7} \mathrm{NMP} / 100 \mathrm{~mL} \text {. }\end{array}$ & 176 \\
\hline
\end{tabular}




\section{RESUMO}

SOUZA, J.B. (2006). AVALIAÇÃo DE MÉTOdos PARA DESINFECÇÃO DE ÁGUA, EMPREGANDO CLORO, ÁCIDO PERACÉTICO, OZÔNIO E O PROCESSO DE DESINFECÇÃO COMBINADO OZÔNIO/ CLORO. São Carlos, 2006. 176p. Tese (Doutorado) - Escola de Engenharia de São Carlos, Universidade de São Paulo.

Foi realizado estudo de desinfecção comparativo, em condições experimentais similares, entre hipoclorito de sódio, ácido peracético, ozônio e o processo de desinfecção seqüencial ozônio / cloro para águas de estudo com características de cor baixa ( $<5 \mathrm{uH}$ ) e cor elevada ( $>100 \mathrm{uH})$. O desempenho dos desinfetantes foi avaliado segundo a inativação de três microrganismos indicadores, Escherichia colli ATCC 11229, colifagos e Clostridium perfringens ATCC 13124. As concentrações aplicadas de cloro $\left(\mathrm{Cl}_{2}\right)$, ácido peracético e ozônio $\left(\mathrm{O}_{3}\right)$ foram de 2,0; 3,0; 4,0 e 5,0 $\mathrm{mg} / \mathrm{L}$. A desinfecção seqüencial consistiu das seguintes combinações de concentrações em

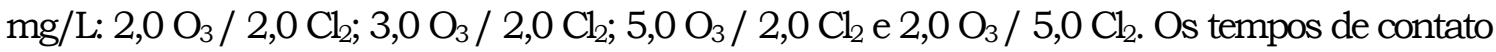
empregados foram de 5, 10, 15 e 20 minutos, tanto para os ensaios individuais, como para a etapa seqüencial. O cloro livre aplicado foi rapidamente transformado em formas de cloro combinado, nos primeiros 5 minutos de contato, para todas as dosagens aplicadas, diminuindo a ação desinfetante do mesmo. Os resultados dos ensaios de desinfecção com ácido peracético indicaram efetiva redução dos microrganismos indicadores empregados, mesmo na presença de elevada concentração de matéria orgânica, proveniente dos meios de cultura. O ozônio foi considerado efetivo para inativação dos três microrganismos indicadores, apresentando melhores resultados que os demais desinfetantes, na inativação dos fagos. Na etapa da desinfecção seqüencial as inativações de $E$. coli, colifagos e $C$. perfringens foram substancialmente superiores às inativações obtidas com ozônio e cloro individuais. Ocorreu sinergismo para E. coli e fagos para todas as dosagens e tempos de contato empregados. Em relação à bactéria esporulada C. perfringens tal fenômeno não foi observado para todos as combinações de ozônio e cloro testadas.

Palauraschave: cloro, ácido peracético, ozônio, desinfecção combinada, microrganismos indicadores. 


\begin{abstract}
SOUZA, J.B. (2006). METHODS EVALUATION FOR WATER DISINFECTION USING CHLORINE, PERACETIC ACID, OZONE AND THE OZONE/CHLORINE COMBINED DISINFECTION PROCESS. São Carlos, 2006. 176p. Tese (Doutorado) - Escola de Engenharia de São Carlos, Universidade de São Paulo.
\end{abstract}

This is the result of a comparative disinfection study, performed in similar experimental conditions, among hypochlorite of sodium, peracetic acid, ozone and the ozone/chlorine sequential disinfection process for waters of study with low color $(<5 \mathrm{uH})$ and high color $>100$ $\mathrm{uH})$ features. The disinfectants performance was evaluated according to the inactivation of three indicators microorganisms: Escherichia coli ATCC 11229, coliphages and Clostridium perfingens ATCC 13124. The applied concentrations of chlorine $\left(\mathrm{Cl}_{2}\right)$, peracetic acid and ozone $\left(\mathrm{O}_{3}\right)$ were of 2,0; 3,0; 4,0 and 5,0 mg/L. The sequential disinfection consisted of the following concentrations combinations in $\mathrm{mg} / \mathrm{L}: 2,0 \mathrm{O}_{3} / 2,0 \mathrm{Cl}_{2} ; 3,0 \mathrm{O}_{3} / 2,0 \mathrm{Cl}_{2} ; 5,0 \mathrm{O}_{3} / 2,0 \mathrm{Cl}_{2}$ and $2,0 \mathrm{O}_{3} / 5,0 \mathrm{Cl}_{2}$. The different times of contact employed were of 5, 10, 15 and 20 minutes, as for the single test, as for the sequential stage. The free chlorine applied was quickly transformed into combined chlorine forms, in the first 5 minutes of contact, for all the dosages applied, reducing its disinfectant action. The disinfection tests results with peracetic acid indicated an effective reduction of the indicators microorganisms employed, even in the presence of a high concentration of organic matters, deriving from the culture medium. The ozone was considered effective for the inactivation of all the three indicators microorganisms, presenting better results than the other disinfectants for the phages inactivation. In the stage of the sequential disinfection, the inactivations of $E$. coli, coliphages and $C$. perfringens were remarkably superior to the inactivations obtained with just ozone and chlorine. It occurred synergism to $E$. coli and phages for all dosages and times of contact employed. Such a phenomenon was not observed in relation to the sporulated bacteria C. perfringens, for all the combinations of ozone and chlorine tested.

Key-words: chlorine, peracetic acid, ozone, combined disinfection, indicators microorganisms. 


\section{1 - INTRODUÇÃO}

O objetivo primário da desinfecção da água é a inativação de bactérias e virus entéricos patogênicos. O cloro exerce predominantemente essa função, contribuindo para a manutenção da qualidade microbiológica da água de consumo há mais de um século. Nas últimas décadas, entretanto, a emergência de patogênicos anteriormente desconhecidos, cepas de microrganismos resistentes a drogas / antibióticos ou que adquiriram novos fatores de virulência, dentre outros, acarretaram em mudanças nos setores de abastecimento de água e saúde pública. Embora algum nível de inativação desses patogênicos seja alcançado com a cloração, pesquisas recentes acompanhadas de documentos sobre surtos de doenças de veiculação hídrica provocadas por esses parasitas, comprovam, na maioria dos casos, a insuficiência da cloração.

Além disso, a meta de se alcançar elevados níveis de desinfecção confronta, freqüentemente, com a possibilidade de formação de subprodutos da desinfecção (SPD) - vários deles suspeitos de causarem câncer em seres humanos. Os primeiros SPD detectados e estudados foram associados com o cloro, embora, atualmente, seja consenso que todos os oxidantes os produzem.

Assim, assegurar desinfecção adequada e limitada formação de subprodutos é o grande desafio da indústria da água de abastecimento.

Muito se tem questionado sobre qual seria o processo de desinfecção “ideal”. CAIRNS (1995) propõe que esse deveria apresentar os seguintes atributos:

- inativar todos os patogênicos, com obtenção de concentração de organismos viáveis abaixo do limite de detecção, ou em níveis que assegurem risco mínimo de transmissão de doenças (axioma: o organismo indicador usado deveria refletir a inativação do organismo mais resistente/ abundante/ infeccioso/ debilitador/ etc);

- ser pouco sensível à variação dos parâmetros físico-químicos da água;

- não produzir subprodutos durante o processo de desinfecção; 
- inativar patogênicos mesmo na presença de material particulado na água;

- impedir eventuais processos de reparo do dano provocado ao organismo pelo desinfetante;

- apresentar custo acessivel e facilidade para ser incorporado às demais etapas de tratamento em que esteja inserido.

Não existe desinfetante "ideal" para toda e qualquer situação, ou capaz de apresentar conjuntamente todos os atributos propostos por CAIRNS (1995). O que deve ocorrer é a avaliação criteriosa e idônea sobre as diversas tecnologias e processos de desinfecção existentes e escolher entre um ou mais processos, os que aplicados isoladamente ou de forma combinada, possam vir a ser os mais eficazes, sob determinadas circunstâncias, às finalidades a que se destinam. Tal é a proposta da USEPA (1999), que admite para algumas situações, a escolha de não apenas um desinfetante, e sim, de uma 'estratégia' de desinfecção.

Nesse contexto, pesquisas sobre processos de desinfecção alternativos ao cloro, bem como o uso diversificado de microrganismos indicadores, despertam interesse e são realizadas em todo o mundo. Por ser algo ainda relativamente novo, estudos referentes às dosagens aplicadas, tempos de contato, possibilidade de formação de subprodutos potencialmente perigosos à saúde humana e efetividade de desinfecção em diferentes grupos de microrganismos constituem vasto e promissor campo para muitas pesquisas.

O ácido peracético é um forte desinfetante com largo espectro de atividade antimicrobiana, é usado em várias indústrias incluindo as de processamento de alimentos, bebidas, médica, farmacêutica, têxtil, de polpa e de papel. Devido às suas propriedades bactericidas, virucidas, fungicidas e esporicidas, seu uso como desinfetante recebe cada vez mais atenção (BALDRY, 1982; BALDRY \& FRENCH, 1989; ALASRI et al., 1992; SANCHEZRUIZ et al., 1995; GASI et al., 1995; RAJALA-MUSTONEN et al., 1997; BLOCK, 2001). Como desinfetante de esgoto o ácido peracético apresenta como vantagens: facilidade de implementação de tratamento (sem a necessidade de 
elevado investimento), largo espectro de atividade mesmo na presença de matéria orgânica heterogênea, ausência de residual ou subprodutos tóxicos e/ou mutagênicos, desnecessária descloração, baixa dependência do pH e curto tempo de contato.

Em água de abastecimento sua utilização é reportada principalmente como pré-desinfetante, sendo que o cloro deve ainda ser usado como desinfetante secundário, para manutenção de residual.

O ozônio é um potente oxidante e desinfetante. Não é muito utilizado no Brasil, mas bastante empregado na Europa e em pequenas instalações de tratamento de água dos EUA (DANIEL, et al. 2001).

Dentre os desinfetantes alternativos ao cloro, o ozônio tornou-se notório nas últimas décadas em função da implementação de padrões cada vez mais restritivos em relação aos subprodutos da cloração, e devido à elevada efetividade do mesmo na inativação de microrganismos patogênicos de difícil inativação como oocistos de Cryptosporidium.

De fato, segundo USEPA (1999), o ozônio não forma subprodutos halogenados (THMs e AHAs), entretanto, pode formar vários outros subprodutos orgânicos e inorgânicos. Ainda, na presença do íon brometo, subprodutos halogenados resultantes da ozonização, análogos aos da cloração, podem ser formados. Sendo que, esses últimos são considerados de maior risco para a saúde humana que os SPD não- brominados.

LANGLAIS (1991) discute que é elevada a complexidade da formação e do controle dos subprodutos da ozonização. O ozônio provoca alterações tanto na formação quanto na concentração dos subprodutos na água final. Sendo que essas modificações são devidas à capacidade que o mesmo possui de: (1) destruir ou formar, imediatamente, subprodutos; (2) destruir ou gerar agentes precursores; (3) alterar determinadas características da água de modo que os processos de tratamento subseqüentes possam ser melhores ou piores na remoção dos subprodutos formados; (4) alterar determinadas características da água de modo que os processos de tratamento subseqüentes possam ser melhores ou piores na remoção dos agentes precursores da formação de subprodutos; e, (5) permitir o uso de menores dosagens de outros 
desinfetantes que porventura sejam usados, ou ainda, permitir alterações do ponto de aplicação dos mesmos.

Entretanto, a principal dificuldade de implementação da ozonização para tratamento de água é a impossibilidade de o ozônio produzir residual que previna eventual contaminação do sistema de distribuição de água. Para ZARPELON \& RODRIGUES (2002), tal fator assume fundamental importância no Brasil, uma vez que, nossos sistemas distribuidores possuem regiões operando com baixa pressão e sujeitos às conseqüências da pressão negativa.

O emprego de dois ou mais desinfetantes, aplicados seqüencialmente ou simultaneamente, caracteriza o processo de desinfecção denominado pela USEPA (1999) de interativo, ou ainda, processo combinado.

Quando o processo interativo produz efeito de inativação de microrganismos adicional ao esperado pelos desinfetantes individuais, tal efeito é denominado Sinergismo.

Vários estudos na literatura reportam a ocorrência de sinergismo durante a desinfecção combinada. Sinergismo foi observado na inativação de E. coli quando exposta simultaneamente ao cloro livre e monocloramina (KOUAME \& HAAS, 1991), na inativação de oocistos de Cryptosporidium parvum e esporos de Clostridium perfringens empregando mistura de oxidantes (VENCZEL, 1997), na inativação de oocistos de Cryptosporidium parvum com a aplicação seqüencial ozônio/cloro livre (DRIEDGER et al., 2000), na inativação de Cryptosporidium e Giardia empregando diversos processos combinados: ozônio/cloro livre, ozônio/monocloramina, cloro livre/monocloramina, dióxido de cloro/cloro livre, dióxido de cloro/monocloramina, ozônio/dióxido de cloro (FINCH et al., 2000).

Além disso, desinfetantes altamente efetivos como ozônio, ácido peracético, radiação UV, etc., que têm seu uso limitado para tratamento de água, por não fornecerem residual ao sistema de distribuição, podem ser combinados a outros, como o cloro, que apresentam essa propriedade. Os processos combinados podem ainda ser otimizados visando obter máxima inativação de microrganismos e mínima formação de SPDs. 
Para a USEPA (1999) a principal limitação quanto ao emprego dos processos combinados refere-se ao fato de que os dados sobre eficiência de inativação ainda estão sendo gerados, de modo que, a maioria das informações disponiveis referem-se a estudos realizados sob condições controladas de laboratório. Informações adicionais são necessárias, especificamente para implementação em escala real.

Entretanto, para KOUAME \& HAAS (1991) a principal limitação da desinfecção combinada é o parco conhecimento concernente ao fenômeno do sinergismo. FINCH et al. (2000), questiona que, além dos mecanismos de ação dos desinfetantes envolvidos, a interferência do $\mathrm{pH}$ e da temperatura são fatores muito relevantes ao processo e que necessitam ser melhor estudados.

No departamento de Hidráulica e Saneamento da Escola de Engenharia de São Carlos da Universidade de São Paulo pesquisas relacionadas ao tema desinfecção de águas e efluentes domésticos são realizadas desde o final da década de 1970.

Dentro dessa temática, os primeiros trabalhos realizados foram: "Desinfecção com radiação ultravioleta" (CAMPOS \& PIZZIRANI, 1977); "Desinfecção de esgotos sanitários com utilização de radiação ultravioleta" (SAMPAIO, 1985); - "Desinfecção de efluentes de esgoto sanitário prédecantado empregando radiação ultravioleta" (DANIEL, 1989); - "Desinfecção de esgotos com radiação ultravioleta” (DANIEL, 1993).

Posteriormente no âmbito do PROSAB, Edital 2, foi realizada a pesquisa Métodos Alternativos de Desinfecção de Água, contemplando o trabalho "Desinfecção de águas com cor e turbidez elevadas: comparação técnica de processos alternativos ao cloro empregando radiação ultravioleta e ácido peracético" (SOUZA, 2000).

Em prosseguimento aos estudos de desinfecção de efluentes seguiram as pesquisas de BILOTTA (2000) - "Estudo comparativo da ação do ozônio e radiação ultravioleta na desinfecção de esgoto sanitário"; DIAS (2001) "Radiação ultravioleta e ozônio aplicados como métodos alternativos de desinfecção de efluentes secundários de esgoto sanitário"; COLETTI (2003) "Inativação de microrganismos indicadores presentes em efluentes secundários 
de esgoto sanitário com radiação ultravioleta"; SARTORI (2004) - "Adequação da qualidade microbiológica de efluentes de esgoto sanitário pela aplicação dos desinfetantes ozônio, permanganato de potássio e ácido peracético" e FERREIRA (2005) - "Fotocatálise heterogênea com $\mathrm{TiO}_{2}$ aplicada ao tratamento de esgoto sanitário secundário".

O presente trabalho enfoca o uso do cloro, ozônio, ácido peracético e do processo combinado ozônio / cloro na desinfecção de água. 


\section{2 - OBJETIVOS}

\section{Objetivo Geral}

- Desinfecção de água, com cloro, ácido peracético, ozônio e o processo combinado ozônio/ cloro, sob condições controladas de laboratório.

\section{Objetivos especificos}

- Inativação dos microrganismos indicadores Escherichia coli, colifagos e Clostridium perfringens com os processos de desinfecção empregados;

- Variar as dosagens e os tempos de contato dos desinfetantes empregados no estudo, e avaliar o efeito desses parâmetros sobre os microrganismos indicadores e sobre a matéria orgânica presente na água de estudo;

- Comparar a resistência dos microrganismos E. coli, colifagos e $C$. perfringens à ação do cloro, ácido peracético, ozônio e processo combinado: ozônio/ cloro;

- Empregando o processo combinado: ozônio/ cloro, determinar a ocorrência ou não de sinergismo na inativação dos microrganismos indicadores $E$. coli, colifagos e C. perfringens. 


\section{3 - REVISÃO DA LITERATURA}

\section{1 - Doenças de transmissão hídrica - patogênicos clássicos e emergentes}

No século XVII o microscopista amador Antony Van Leeuwenhoek (16321723) descobriu 'numa minúscula gota d’água um mundo incrivel e até então desconhecido - o mundo microbiológico', alertando pela primeira vez para as formas microscópicas de vida. Vários anos se passaram e, com o trabalho incansável de cientistas pioneiros, curiosos e perspicazes, as bases da Microbiologia se consolidaram. No entanto, até meados do século XIX acreditava-se ainda que as doenças eram causadas por fatores vagos, tais como o ar ou sangue ruins (PELCZAR, 1996).

A água, especificamente, foi reconhecida como veículo transmissor de doenças somente na segunda metade do século XIX, com o trabalho do médico inglês John Snow ${ }^{1}$.

SCHOENEN (2002) cita que até o fim do século XIX apenas duas doenças graves - cólera e febre tifóide - eram conhecidas serem veiculadas pela água. A partir da descoberta dos patogênicos baseada nos trabalhos de Louis Pasteur (1822-1895), Ferdinand Cohn (1828-1898) e Robert Koch (1842-1910) é que se tomou conhecimento de que muitas doenças podem ser causadas por microrganismos e que também muitos desses podem ser veiculados pela água.

No século XIX, com a industrialização, o rápido crescimento das cidades e a crescente demanda por água, os sistemas de distribuição começaram a ser construídos rapidamente. Entretanto, ainda eram incipientes os conceitos sobre qualidade da água. Tal fato é refletido pela caricatura de Prey "A Sopa de Monstros" (Figura 3.1).

\footnotetext{
${ }^{1}$ Snow comprovou sua teoria em um episódio acontecido em 1854 na cidade de Londres. Após mapear as mortes ocorridas durante a epidemia de cólera, Snow constatou que todas ocorreram num raio de $230 \mathrm{~m}$ nas cercanias da estação de Broad Street. Ao remover a bomba, impediu a comunidade de se abastecer da fonte d'água, resultando na estabilização imediata do número de infectados pela epidemia de cólera (WHITE, 1986 apud DANIEL ${ }^{2}, 2001$ ).

${ }^{2}$ DANIEL, L.A. (2001) -Processos de desinfecção e desinfetantes alternativos na produção de água potável. Luiz Antonio Daniel (coordenador). Rio de Janeiro: RiMA, ABES, 2001. 155p.
} 


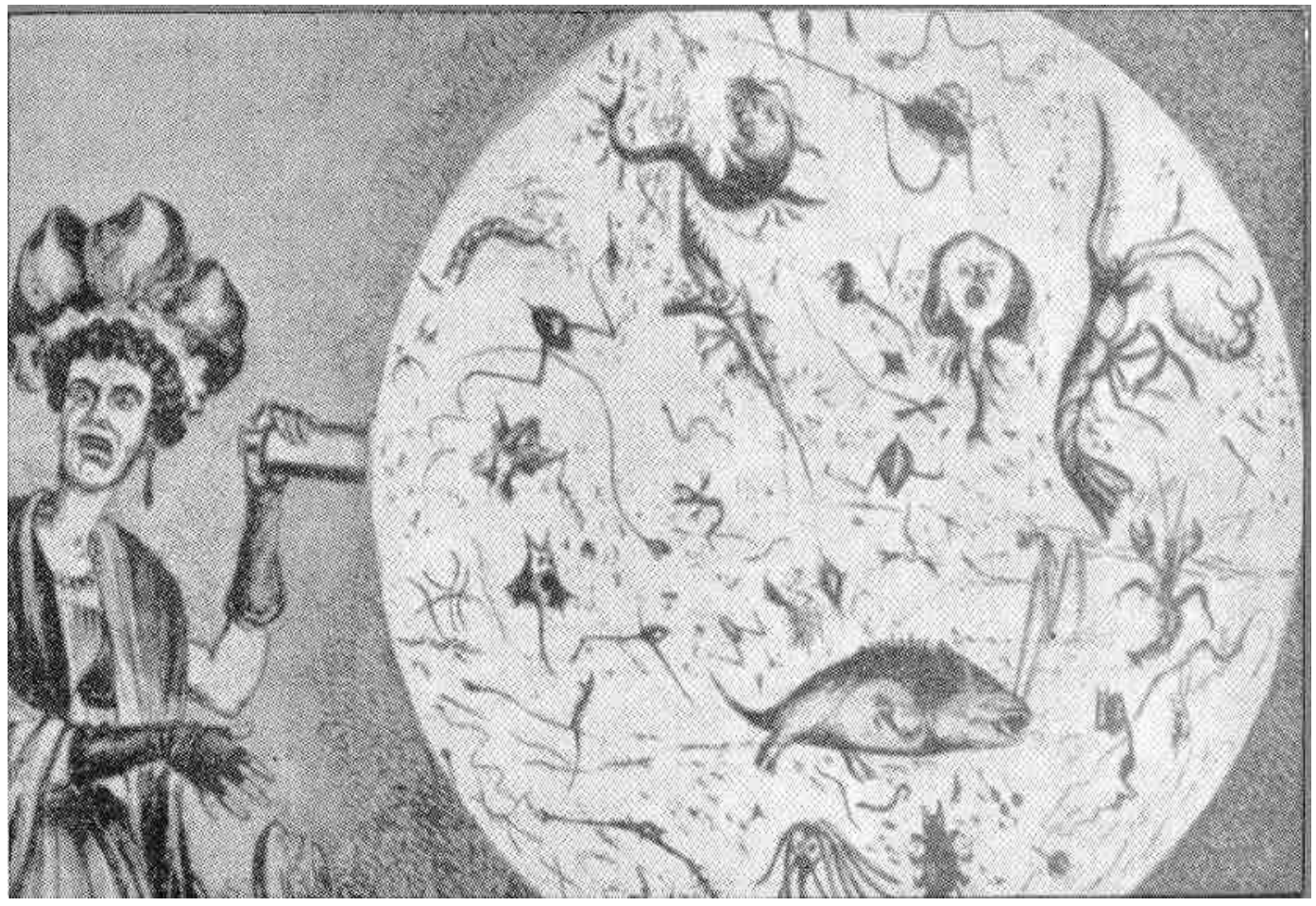

FIGURA 3.1 - Caricatura de Prey - 'A sopa de monstros'.

[Fonte: SHOENEN (2002)].

Com o aumento da incidência de doenças de veiculação hídrica começaram a surgir as primeiras medidas (em grande escala) para o tratamento da água de consumo, destacando a filtração, que era realizada com o objetivo de eliminar turbidez e odores, e a desinfecção, cujo objetivo, ainda baseado em idéias ultrapassadas, era eliminar odores ruins. Assim, a cloração e a ozonização despontaram como os principais processos de desinfecção.

No início do século XX a cloração foi introduzida de maneira mais efetiva, objetivando a diminuição da propagação de doenças pela água, o que indubitavelmente contribuiu para tal fim, destacando como exemplo, a redução do índice de mortalidade por febre tifóide em todo o mundo na época.

A partir de então, desde que a água de abastecimento passou a ser clorada, há mais de um século, a cloração exerceu papel dominante e providenciou segurança microbiológica à água (TRUSSELL, 1999). É um monopólio tradicional que nenhum outro desinfetante jamais igualou. 
Atualmente, a despeito do uso mundialmente difundido do cloro como principal desinfetante de água de abastecimento, surtos de doenças de veiculação hídrica continuam ocorrendo, não apenas em países em desenvolvimento, mas também em países industrializados, nos quais os padrões de higiene são bastante rigorosos e prescritos por severas regulamentações. Exemplos conhecidos foram os surtos de Cryptosporidium parvum em Milwaukee, Estados Unidos, em 1993 e toxoplasmose em Victoria, Canadá, 1994 (SCHOENEN, 2002).

Nas últimas décadas intensificaram-se os surtos de doenças relacionadas à presença de patogênicos denominados "emergentes" na água produzida e distribuída à população. Incluem nesse grupo patogênicos de origem fecal, dentre eles, Campylobacter jejuni, Escherichia coli patogênica, Yersinia enterocolitica, virus entéricos como rotavirus, calicivírus, pequeno virus redondo estruturado, astrovírus, os parasitas Giardia lamblia, Cryptosporidium parvum e microsporídia, assim como, espécies de bactérias ambientais capazes de crescer nos sistemas de distribuição de água e que há poucos anos foram considerados patogênicos relevantes, como, Legionella spp., Aeromonas spp., Mycobacterium spp. e Pseudomonas aeruginosa. Além desses patogênicos, outro grande problema para a indústria da água de abastecimento é a produção de toxinas por cianobactérias presentes em mananciais superficiais (SZEWZYK et al., 2000).

As razões para a 'emergência' desses novos patogênicos são amplamente discutidas na literatura por vários autores. BLACK (1999), SZEWZYK et al. (2000), COHEN (2001), ressaltam que muitos desses patogênicos não são efetivamente novos e podem ter causado doenças por muitos anos, porém, não tinham sido identificados anteriormente por falta de métodos de detecção específicos. Outros não eram associados com a água consumida ou eram conhecidos apenas como patogênicos para animais como, por exemplo, Cryptosporidium, que foi descrito em 1907, reconhecido como patogênico para animais em 1955, mas somente nas últimas décadas foi reconhecido como causador de doenças aos seres humanos. 
Segundo esses mesmos autores, doenças anteriormente desconhecidas ou raras tornaram-se significativas como resultado de mudanças nas atividades das pessoas e/ou das condições sociais, como, mudanças nos hábitos dos usuários de água, com crescente demanda por água aquecida, cujos reservatórios domiciliares propiciam o crescimento de microrganismos como Legionella spp., P. aeruginosa e micobactéria ambiental. Surgimento de cepas de bactérias resistentes a antibióticos, que adquiriram novos fatores de virulência, como a E. coli enteroemorrágica (EHEC); aumento do número de pessoas susceptiveis a infecções, dentre eles, imunodeficientes, transplantados, pessoas que receberam tratamento quimioterápico, etc.

Muito embora, nos últimos anos, novas cepas de patogênicos tenham sido descobertas ${ }^{3}$, acarretando em mudanças importantes nos setores de abastecimento de água e saúde pública, significativa proporção do imenso rol de doenças de veiculação hídrica ainda é causada por patogênicos 'clássicos' como Salmonella typhi e Vibrio cholerae (OMS, 2003).

$\mathrm{Na}$ tabela 3.1 estão listadas algumas doenças conhecidas que podem ser transmitidas pela água, via rota feco-oral.

Tabela 3.1 - Principais doenças causadas por patogênicos veiculados pela água.

\begin{tabular}{ccc}
\hline Bactéria & Vírus & Protozoário \\
\hline Cólera & Poliomielite & Amebíase \\
Febre tifóide & Hepatites A e E & Giardiase \\
Febre paratifóide & Enteroviroses & Criptosporidiose \\
Salmonelose & Rotaviroses & Toxoplasmose \\
Shigelose & Adenoviroses & \\
Yersiniose & Gastroenteropatia pelo agente & \\
Enterite campilobacteriana & Norwalk & \\
Infecção por E.coli (EHEC) & Moléstia de Coxsackie & \\
Leptospirose & & \\
\hline
\end{tabular}

Fonte: Adaptado de SCHOENEN (2002).

\footnotetext{
${ }^{3}$ Segundo dados da OMS (2003) entre os anos de 1972 e 1999, 35 novos agentes causadores de doenças foram descobertos, além disso, muitos ressurgiram após longos períodos de inatividade ou multiplicaramse em áreas onde não eram reportados anteriormente.
} 
Uma exceção do grupo feco-oral é a Leptospirose, doença relacionada com a urina excretada por roedores e que pode causar infecção quando em contato com a pele ou após ingestão. Dentre os patogênicos que podem crescer nos sistemas de distribuição de água estão: Pseudomonas aeruginosa, Legionellae, Atypical mycobacteria, Aeromonas hydrophila, Flavobacteria, Acinetobacter, Yersinia e Amoebae (Acantomoeba, Naegleria). Os patogênicos de transmissão feco-oral são usualmente capazes de sobreviver, mas não se multiplicam em ambientes fora dos organismos animais ou humanos. As duas exceções dessa regra são as bactérias Campylobacter a Yersinia, que podem proliferar mesmo na água tratada (SCHOENEN, 2002).

O fato é que, provocadas por patogênicos denominados clássicos ou emergentes, as doenças de transmissão hídrica continuam entre as principais causas de morbidade e mortalidade em todo o mundo, especialmente nos países em desenvolvimento.

\section{2 - Desinfecção da água de abastecimento - mudança de paradigma}

Atualmente, questões complexas permeiam a indústria da água de abastecimento. O cloro - desinfetante mais usado em todo o mundo para tratamento de água - nas concentrações normalmente empregadas nas ETAs, não é eficaz na inativação de parasitas como Cryptosporidium, Giardia e outros patogênicos emergentes, considerados hoje, de grande relevância no tratamento de água. Assim, como regulamentar tal situação?

Especificamente para o caso de cistos e oocistos de protozoários, de acordo com HELLER (2004), os mesmos devem ser removidos ou inativados em instalações de tratamento de água por meio de dois grupos de processos: processos projetados para remoção de sólidos, já que cistos e oocistos comportam-se como partículas, e - processos de desinfecção, já que estes são formas vivas de microrganismos.

Quanto à remoção física dos patogênicos nos decantadores e filtros, ISAAC (2004) aborda dois fatos que devem ser levados em consideração: as condições operacionais dessas unidades devem ser ótimas (oocistos de 
Cryptosporidium, em especial, apresentam certas características morfológicas que dificultam sua remoção); ainda, os cistos e oocistos removidos irão concentrar-se tanto no lodo dos decantadores quanto na água de lavagem dos filtros. Em regiões em que se tem escassez de água, ou em que o custo para transportar a água do manancial até a ETA seja elevado, faz-se necessário ou interessante, do ponto de vista econômico, a recuperação e a recirculação de água na própria estação. A água de lavagem dos filtros no Estado de São Paulo, por exemplo, é geralmente descartada no sistema de esgoto ou recirculada, após equalização, para o início da estação. O lodo, à exceção das ETAs que já implantaram estações de tratamento de lodo, é lançado no ambiente, e pode comprometer significativamente a qualidade da água à jusante, e a saúde pública, em geral.

Em relação aos processos de desinfecção, HELLER (2004) discute que, em geral, não se espera qualquer inativação de cistos e oocistos com a aplicação de cloro e de monocloramina, sendo possivel alcançar alguma com dióxido de cloro, ozônio e radiação ultravioleta. Os cistos e oocistos de protozoários, sendo que os últimos mais que os primeiros, são muito mais resistentes a qualquer desinfetante químico que bactérias e vírus, exigem, portanto, ao se empregar processos como ozonização ou dióxido de cloro, relação $C T$ muito alta, resultando em elevados custos de tratamento.

Ainda, os oocistos possuem características muito peculiares e usualmente ocorrem em baixas densidades na água, tornando sua quantificação complexa e demorada. Conseqüentemente, os procedimentos disponiveis atualmente, para quantificar sua inativação não são apropriados para monitoramento de rotina da qualidade da água (BAEZA \& DUCOSTE, 2004).

A avaliação da quantidade de patogênicos presentes na água é outro ponto polêmico e questionável no tratamento da água de consumo. Tal avaliação difere conforme a legislação nacional.

No Brasil, os padrões de potabilidade e os procedimentos relativos ao controle e vigilância da qualidade da água para consumo humano foram 
revisados e estabelecidos na Portaria do Ministério da Saúde no 518, de 25 de março de 2004.

$\mathrm{Na}$ Portaria 518/ 2004 não há uma determinação obrigatória para a pesquisa de patogênicos, porém, no Artigo 11 da mesma, recomenda-se “... $a$ inclusão de pesquisa de organismos patogênicos, com o objetivo de atingir, como meta, um padrão de ausência, dentre outros, de enterovírus, cistos de Giardia spp e oocistos de Cryptosporidium sp" (MS, 2004).

Para SZEWZYK et al. (2000) a meta de completa ausência de todos os organismos patogênicos na água de abastecimento é difícil de ocorrer, especialmente mediante os patogênicos emergentes, alguns, inclusive, são capazes de multiplicarem-se no sistema de distribuição de água.

A CETESB, que avalia a qualidade das águas superficiais do Estado de São Paulo, monitorou durante 4 anos (janeiro de 1999 a dezembro de 2002) a concentração dos parasitas Giardia e Cryptosporidium, juntamente com coliformes termotolerantes, enterococos e C. perfringens, com o objetivo de conhecer a ocorrência desses parasitas na água, bem como incluir os resultados num índice de qualidade de água para abastecimento (IAP), introduzido recentemente. Os dados obtidos foram avaliados tendo como referência a legislação americana de monitoramento (ICR - Information Collection Rule), uma vez que, a legislação brasileira não determina o monitoramento desses protozoários ou quaisquer outros patogênicos em águas captadas para consumo humano. De acordo com essa regulamentação, seria necessário monitorar a água tratada em 16 pontos de captação com resultados positivos na primeira fase do estudo, e em 6 desses pontos da segunda fase, uma vez que nesses locais foram detectadas concentrações superiores a 10 cistos de Giardia/L ou 10 oocistos de Cryptosporidium/L (HACHICH, 2004).

Nos EUA, trabalha-se com a visão de risco aceitável. A EPA definiu esse risco como $10^{-4}$ anuais, ou seja, uma infecção em cada 10.000 indivíduos por ano, para doenças adquiridas com o consumo de água tratada. Tal valor conduz ao conceito de nível aceitável. Na água tratada, o nível aceitável de oocistos de C. parvum, por exemplo, é de cerca de 6x10-4 /10L [SZEWZYK et al. (2000), HELLER (2004)]. 
Para CAIRNS (1995) a proposta de "redução do número de patogênicos até o nivel em que seja aceitável o risco de infecção" é bastante controversa e desafiadora, tanto do ponto de vista técnico quanto científico, uma vez que, não há como comparar risco entre doenças diferentes. Além disso, determinados patogênicos têm menor dose infecciosa, são mais resistentes à desinfecção, são mais ou menos letais ou debilitadores. Dessa forma, torna-se extremamente comprometedor assegurar adequada proteção ao consumidor em um caso infortúnio, em que ocorra na água, elevado número de patógenos letais / debilitadores, que apresentam baixa dose infecciosa e elevada resistência à desinfecção.

Aliado ao objetivo primário das ETAs de assegurar a efetividade da desinfecção, está a necessidade de minimização da formação dos subprodutos da desinfecção (SPD), que são associados a potenciais prejuízos à saúde humana.

Os primeiros SPDs identificados na água de consumo foram os THMs, relacionados com a cloração de águas contendo matéria orgânica natural (MON). A partir de então, vários outros subprodutos foram identificados, acarretando em extensivas investigações, diversas regulamentações e documentos referentes aos níveis máximos permitidos, a formação, os maleficios potenciais, e as alternativas de controle dos mesmos.

No Brasil, o valor máximo permitido (VMP) o total de trihalometanos (TTHM) é de 0,1 mg/L. Esse valor é referido no Art. 14 da Portaria 518 MS/2004 em que é apresentada tabela relativa ao padrão de potabilidade para substâncias químicas que representam risco para a saúde.

Dentre as propostas para controle da formação de THMs, ácidos haloacéticos (AHAs), e demais derivados clorados está a substituição do cloro por oxidantes alternativos. No entanto, tal solução levará a outros potenciais subprodutos, uma vez que todos os oxidantes inevitavelmente os produzem. Nas reações de oxi-redução, a massa não pode ser criada nem destruída, logo, algum subproduto será produzido. Vale ressaltar, os subprodutos da cloração são estudados desde a década de 1970 e, ainda assim, considera-se pequeno o 
percentual dos subprodutos halogenados identificados até o presente (OXENFORD, 1996; HARMS, 2002).

O residual desinfetante que o cloro providencia ao sistema distribuidor é outro aspecto relevante a ser levado em consideração. Inclusive, no Brasil, é exigência de lei.

No Artigo 13 da Portaria 518/2004, fica estabelecido que: “após a desinfecção, a água deve conter um teor mínimo de cloro residual livre de 0,5 $\mathrm{mg} / \mathrm{L}$, sendo obrigatória a manutenção de, no mínimo, 0,2 mg/L em qualquer ponto da rede de distribuição, recomenda-se que a cloração seja realizada em pH inferior a 8,0 e tempo de contato mínimo de 30 minutos".

Há que se considerar também a responsabilidade técnica que recai sobre o administrador da ETA:

"Admite-se a utilização de outro agente desinfetante ou outra condição de operação do processo de desinfecção, desde que fique demonstrado pelo responsável pelo sistema de tratamento uma eficiência de inativação microbiológica equivalente à obtida com a condição definida neste artigo" [Parágrafo único, MS (2004)].

Devido a multiplicidade de fatores que envolvem os processos de desinfecção, não há como avaliar pontualmente o desinfetante, ou o tratamento mais adequado. As agências de regulação internacionais admitem que, em muitos casos, o que deve ocorrer é a avaliação de uma estratégia de desinfecção que envolve condições especificas de cada sistema de abastecimento. A escolha da estratégia de desinfecção apropriada, se fundamenta no balanço entre três aspectos principais: água isenta de patogênicos; controle da formação de subprodutos, e manutenção de residual desinfetante no sistema distribuidor (USEPA, 1999).

De acordo com HELLER (2004) "é fundamental que se considere a visão de contexto do problema - do manancial até o ponto de consumo - para se recomendarem as soluções mais seguras".

Em relação aos patogênicos, a segurança quanto à ausência ou presença em níveis seguros, passa por uma visão sistêmica do processo, o que inclui os conceitos de barreiras múltiplas e de boas práticas no abastecimento 
de água, a metodologia de avaliação de riscos e a implementação dos planos de segurança da água, em consonância com o que prevê a Portaria 518 e a terceira edição dos guias de qualidade da água para consumo humano da OMS (HELLER, 2004).

Em relação aos SPDs, segundo OXENFORD (1996) a melhor opção para o controle é a remoção ou redução dos precursores (MON). Para tal, há três diferentes alternativas: o controle dos precursores na fonte, que requer manejo do manancial de captação; a remoção física / química dos precursores, que inclui os processos de coagulação, adsorção e separação em membranas; e a oxidação / transformação que envolve mudança da forma da MON, que inclui ozonização combinada com tratamento biológico (aumento da biodegradabilidade da MON), fotocatálise e outros processos de oxidação. Está claro que o resultado de cada uma dessas opções varia em função da qualidade da água e dos objetivos do tratamento. Custo, complexidade operacional, e fatores ambientais também devem ser avaliados. A remoção dos SPDs após sua formação também é tecnicamente possivel, embora deva ser considerada alternativa secundária.

Para ZARPELON \& RODRIGUES (2002), no caso do Brasil e de outros países em desenvolvimento torna-se imprescindivel, primeiramente, maximizar a proteção à saúde pública através do gerenciamento entre os riscos microbiológicos e os riscos dos contaminantes químicos na água potável; a seguir, a adoção de amplos programas de apoio tecnológico, que induzam ações racionais em sintonia com a capacidade de resposta da estrutura de saneamento existente. Ainda, que se aprofundem as pesquisas sobre os SPDs e outras alternativas de desinfecção para as águas de abastecimento público.

\section{3 - Microrganismos indicadores}

Por limitações de ordem prática, técnica e econômica é impossivel examinar todos os potenciais organismos patogênicos presentes na água. Tradicionalmente são usados microrganismos indicadores para sugerir a ocorrência de contaminação fecal, verificar a eficiência de processos de 
tratamento de água e esgoto e possivel deterioração ou pós-contaminação da água no sistema de distribuição.

Alguns critérios são propostos para a validação dos indicadores: (i) devem estar presentes quando patogênicos estão presentes e ausentes quando patogênicos estão ausentes; (ii) as características de persistência e crescimento de ambos devem ser semelhantes; (iii) patogênicos e indicadores devem ocorrer em niveis constantes para que a contagem dos indicadores seja boa estimativa do número de patogênicos presentes; (iv) preferivelmente, o indicador deve estar presente nas fontes poluidoras em indices mais elevados do que a concentração de patogênicos; (v) o indicador deve ser tão resistente quanto o patogênico às condições ambientais e aos desinfetantes; (vi) o indicador deve ser facilmente quantificável e não patogênico; (vii) os testes para quantificação do indicador devem ser aplicáveis a todos tipos de água; (viii) os testes devem quantificar apenas o organismo indicador e não dar reações falso-positivas (STETLER, 1984).

Não existe microrganismo indicador universalmente aceito. A validade de qualquer indicador é afetada pela sua taxa relativa de remoção e destruição versus a do organismo-alvo, diferenças de resistência ambiental ou mesmo habilidade de multiplicar-se no ambiente, e ainda, vírus, bactérias, protozoários e helmintos não possuem obviamente o mesmo comportamento que um único grupo indicador e, nem certamente em todas as situações (BERG \& METCALF, 1978).

Os indicadores são usados para sugerir a presença de patogênicos, muito embora não exista relação direta entre organismos indicadores e patogênicos entéricos. Em decorrência, por diversas razões, podem ocorrer falhas quanto à presença do indicador e ausência de patogênicos ou vice-versa. Para eliminar a ambigüidade do termo 'indicador microbiológico', são reconhecidos pela OMS, os grupos: (a) Indicador de processo; (b) Indicador fecal e (c) Organismo índice ou modelo.

São apresentados na Tabela 3.2 os principais microrganismos indicadores de contaminação fecal (ou, os mais comumente usados), e na Tabela 3.3 as definições propostas pela OMS (2002). 
Tabela 3.2 - Principais microrganismos indicadores de contaminação fecal.

Coliformes totais (bactérias do grupo coliforme): bacilos gram-negativos, aeróbios ou anaeróbios facultativos, não formadores de esporos, oxidasenegativos, capazes de desenvolver na presença de sais biliares ou agentes tensoativos que fermentam a lactose com produção de ácido, gás e aldeído a $35,0 \pm 0,5{ }^{\circ} \mathrm{C}$ em 24 a 48 horas e que podem apresentar atividade da enzima ßgalactosidase. A maioria das bactérias do grupo coliforme pertence aos gêneros Escherichia, Citrobacter, Klebsiella e Enterobacter, embora vários outros gêneros e espécies pertençam ao grupo. Não são indicadores específicos de poluição fecal.

Coliformes termotolerantes: subgrupo das bactérias do grupo coliforme que fermentam a lactose a 44,5 $\pm 0,2{ }^{\circ} \mathrm{C}$ em 24 horas, tendo como principal representante a Escherichia coli de origem exclusivamente fecal.

Escherichia coli: bactéria do grupo coliforme que fermenta a lactose e manitol, com produção de ácido e gás a $44 \pm 0,2^{\circ} \mathrm{C}$ em 24 horas, produz indol a partir do triptofano, oxidase negativa, não hidrolisa a uréia e apresenta atividade das enzimas $§$-galactosidase e $§$-glucoronidase, sendo considerada o indicador mais específico de contaminação fecal recente e de eventual presença de organismos patogênicos.

Clostridios sulfito redutores (CSR): bacilos gram-positivos, estritamente anaeróbios, imóveis, formadores de esporos, reduzem o sulfito a sulfeto.

Clostridium perfringens: mesmas características dos CSR e ainda fermentam a lactose, manose e sacarose com produção de gás e fermentação turbulenta do leite, reduzem o nitrato, hidrolizam a gelatina, produzem lecitinase e fosfatase ácida. Nem todos os CSR presentes nas águas são indicadores de poluição fecal, apenas C. perfringens são indicadores apropriados.

Bacteriófagos (fagos): são vírus de bactérias, encontrados no meio ambiente. Apropriados para testar a qualidade da água e como modelos de vírus entéricos humano, com maior interesse nos colifagos somáticos, colifagos F-RNA (maleespecific) e os fagos que infectam Bacteroides fragilis.

Fonte: Adaptado da Portaria MS no 518/ 2004. 
Tabela 3.3 - Microrganismos indicadores de processo, indicadores fecais e organismo índice.

\begin{tabular}{ll}
\hline Grupo & Definição \\
\hline & Grupo de organismos usados para demonstrar a \\
Indicador de processo & eficácia de determinado processo. Por exemplo: uso \\
& de bactérias heterotróficas ou coliformes totais para \\
& verificar a efetividade de desinfecção com cloro. \\
& Grupo de organismos que indicam a presença de \\
& contaminação fecal, tais como: coliformes \\
& termotolerantes ou E. coli. No entanto, eles apenas \\
& inferem que patogênicos podem estar presentes. \\
& Grupo ou espécie indicativa da presença ou do \\
comportamento de patogênicos, tais como E. coli \\
Organismo indice ou fecal & como indice de Salmonella e colifagos F-RNA como \\
& modelo de vírus entéricos humano.
\end{tabular}

Fonte: OMS (2002).

Segundo a OMS (2002) nos últimos anos a necessidade de redução do tempo requerido para realização dos exames microbiológicos, o surgimento de novas cepas de patogênicos e os avanços da biologia molecular, tem resultado em numerosos novos métodos de detecção de organismos patogênicos, mais rápidos e específicos. Dentre eles, métodos que empregam substratos cromogênicos (já amplamente usados), métodos imunológicos que usam anticorpos monoclonais e policlonais, método de separação imunomagnética (IMS), métodos baseados em seqüenciamento genético como o PCR (polymerase chain reaction) e o FISH (fluorescence in situ hybridisation) e diversos outros baseados em reconhecimento genético que empregam micro-sensores e biosensores.

Tais métodos são usualmente rápidos, podem detectar desde cepas específicas a grupos de organismos. Já são muito usados na área biomédica e tem potencialidade futura para aplicação no tratamento da água de 
abastecimento, em que poderiam afetar sobremaneira a epidemiologia e a investigação de surtos, em detrimento dos métodos de rotina que testam a qualidade final da água de abastecimento (OMS, 2002). Há que se considerar, entretanto, o custo envolvido na implementação desses novos métodos bem como a capacitação técnica dos laboratórios e profissionais da área.

\subsection{1 - Coliformes fecais e Escherichia coli}

Coliformes fecais são os indicadores usuais de avaliação da qualidade microbiológica de águas. Entretanto, vários estudos têm apresentado falhas quanto ao uso desse grupo, podendo-se citar: (i) baixa sobrevivência fora do trato intestinal, particularmente em ambientes marinhos; (ii) definição incerta como um grupo e (iii) baixa relação com a presença de bactérias patogênicas e vírus. Assim, é importante considerar outros indicadores na avaliação microbiológica das águas, os quais, poderiam exibir relação mais estreita com a presença de patogênicos na água, particularmente aqueles que podem persistir por mais tempo no ambiente.

Membros do grupo coliforme fecal, por exemplo, espécies de Klebsiella e Enterobacter não são específicos das fezes, e mesmo E. coli pode ocorrer em alguns ambientes aquáticos naturais. Assim, E. coli e enterococos são os principais representantes de contaminação fecal em águas de regiões temperadas, e para águas de regiões tropicais, onde $E$. coli pode ocorrer eventualmente sob condições naturais, indicadores alternativos tais como $C$. perfringens devem ser preferidos (OMS, 2002).

Também, conforme CERQUEIRA (1999), o parâmetro coliforme fecal não existe. O que se tem informado como coliformes fecais até hoje pelos laboratórios é a leitura dos coliformes termotolerantes, que incluem a E. coli e espécies dos gêneros Klebsiella e Enterobacter. Desses, apenas a E. coli tem presença garantida nas fezes humanas e de animais homeotérmicos, com percentuais em torno de 96 a 99\%. Os demais gêneros participam com percentuais que variam entre 3 e $8 \%$ em fezes animais a 3 a $4 \%$ em fezes humanas. Tornou-se possivel nos últimos anos, através de testes cromo- 
fluorogênicos baseados em expressões enzimáticas, a detecção simples e rápida de $E$. coli e de outras bactérias específicas para fins de monitoramento de mananciais.

No Brasil, a prática de controle microbiológico de qualidade da água de consumo se fundamenta no controle da presença de bactérias do grupo coliformes (DANIEL, 2001). O padrão microbiológico de potabilidade da água para consumo humano é estabelecido na Portaria MS 518/2004.

As técnicas de detecção de coliformes e E. coli são práticas e relativamente rápidas. São vários os métodos disponíveis, dentre eles, tubos múltiplos, contagem em membranas filtrantes e substratos cromogênicos.

Para CERQUEIRA (1999) as técnicas de detecção e identificação de outros indicadores microbiológicos para funções similares às que são atribuídas aos coliformes fecais devem ser padronizadas e simplificadas, podendo-se assim assegurar ausência de microrganismos patogênicos de maior persistência que essa espécie. Como colifagos, que podem informar sobre a eficiência do tratamento de água na remoção de enterovírus e outros vírus como o da hepatite de veiculação hídrica e C. perfringens que, por ser esporulado, informa sobre poluição fecal mais remota que aquelas indicadas pela presença de E. coli.

\subsection{2 - Colifagos}

Os bacteriófagos ou simplesmente fagos são vírus que infectam bactérias. Foram primeiramente observados em 1915 por Frederic Twort, na Inglaterra, e em 1917 por Felix D'Herelle, na França. D'Herelle os denominou bacteriófagos, que significa "comedores de bactérias". Foram descritos a partir do trato intestinal humano no início dos anos 1900 e seu uso como modelo para indicar presença de bactérias entéricas patogênicas começou na década de 1930 [PELCZAR (1996); BLACK (1999)].

Os fagos que infectam bactérias do grupo coliforme são conhecidos como colifagos. Como os outros vírus, os fagos podem ter sua informação genética na forma de RNA ou DNA, fita dupla ou fita simples. Os fagos designados T2, T4 e 
T6 (T de "tipo") tem o DNA como material genético e os fagos que tem o RNA como material genético são os colifagos F-RNA e adsorvem-se ao flagelo ou aos pili [OMS (2002); BLACK (1999)].

Estudos realizados nas décadas de 1970 e 1980, já sugeriam colifagos como indicadores de qualidade da água e como possíveis modelos de enterovirus após tratamento de água e esgoto [HILTON \& STOTZKY (1973); KOTT et al. (1978); SCARPINO (1978)]. Colifagos e enterovirus são inativados em proporção comparável durante os processos de tratamento. Certos colifagos são tão resistentes quanto alguns enterovírus às condições de estresse ambiental e à cloração e exibem variação sazonal similar aos enterovirus [BERG (1974); KOTT et al. (1974); SIMKOVA \& CERVENKA (1981)]. Entretanto, outras pesquisas reportam que a concentração de colifagos aumenta sob determinadas condições ambientais favoráveis e que colifagos estão presentes na ausência de vírus detectáveis e vice-versa [VAUGHN \& METCALF (1975); DEETZ et al. (1984)].

STETLER (1984) estudou conjuntamente o monitoramento de bactérias indicadoras, enterovirus e colifagos em uma ETA. As concentrações dos colifagos foram determinadas em vários pontos da ETA, incluindo, na água bruta e após as etapas de floculação-sedimentação, filtração em areia e cloração. A quantificação de colifagos foi determinada por ensaio de placa, sendo que para a amostra de água bruta o plaqueamento foi direto e, após as etapas de tratamento, devido às baixas densidades de colifagos e enterovírus encontradas, necessitou-se concentrar as amostras, usando técnica de filtração, eluição e adsorção.

Os dados obtidos pelo autor indicaram que colifagos satisfazem parcialmente os critérios listados para microrganismos indicadores: colifagos e enterovirus apresentaram resistência semelhante; a sazonalidade de ambos também foi semelhante; as concentrações dos fagos na água bruta e após as etapas de tratamento, excederam as concentrações de enterovirus (com exceção da cloração, que causou 100\% de inativação dos virus detectáveis); os processos de tratamento de água removeram / inativaram colifagos e enterovirus em taxas similares; e ainda, colifagos são facilmente quantificados 
por procedimentos tecnicamente simples, econômicos e aplicáveis a vários tipos de qualidade de água. A análise estatística dos dados indicou que os enterovirus isolados foram melhor correlacionados com colifagos do que com coliformes totais, coliformes fecais e estreptococos fecais. O autor concluiu que colifagos tem bom potencial como indicador de enterovírus, em verificação de eficiência de processos de tratamento de água.

STETLER (1984) também avaliou diferentes cepas de bactérias hospedeiras, E. coli A-19, E. coli C (ATCC 13706), E. coli B (ATCC 11303) e E. coli C-3000 (15597) e observou que, com a E. coli C obteve maior recuperação de colifagos. A média de recuperação de colifagos com $E$. coli C foi 2,9 vezes maior do que com E. coli A-19. Ainda, houve flutuação sazonal das concentrações de enterovírus e colifagos ao longo do ano e os dois grupos de vírus seguiram padrão de comportamento similar. Nos meses de outonoinverno os dois grupos foram recuperados em maior número do que nos meses de primavera-verão.

A vantagem dos colifagos como indicador é sua facilidade de enumeração, incluindo reduzido tempo para o resultado final (4 a 6 horas), ainda, as taxas de inativação de colifagos são similares àquelas reportadas para muitos patogênicos. Entretanto, muitos pesquisadores atribuem a maior dificuldade do uso desse indicador ao fato de que sua enumeração requer manutenção de cepa de bactéria hospedeira de boa qualidade. Esta condição pode ser limitante para muitos laboratórios (PAYMENT \& FRANCO, 1993).

Também, de acordo com a OMS (2002) muitas variáveis afetam a incidência, sobrevivência e comportamento dos fagos em águas naturais, dentre elas, as concentrações dos fagos e da bactéria hospedeira, a temperatura e o $\mathrm{pH}$ da água. Ainda, os fagos podem ser recuperados e detectados por meio de muitas técnicas diferentes, além da mesma bactéria hospedeira poder ser usada para a detecção de vários grupos distintos de fagos.

Em relação às cepas hospedeiras dos fagos, LASOBRAS et al. (1997) discorrem que muitas são polivalentes e podem detectar diferentes fagos incluindo os pertencentes a diferentes famílias. Assim, cepas usadas para 
detectar colifagos somáticos, usualmente detectam em conjunto vários bacteriófagos diferentes. Mesmo cepas de E. coli e Salmonella typhimurium, indicadas para detectar preferencialmente os fagos específicos, também detectam fagos somáticos. Estudos reportam que em amostras contendo poluição persistente ou remota são detectados fagos diferentes do que os das amostras de poluição recente, também ocorre diferença quanto aos fagos detectados antes e após os processos de tratamento de água. As observações sugerem que tais variações favorecem alguns tipos particulares de morfologia de fagos.

\subsection{3 - Clostridium perfringens}

Clostrídios Sulfito Redutores são organismos anaeróbios, formadores de esporos sendo que o mais característico é o C. perfringens. Normalmente estão presentes nas fezes (13 a 35\%) embora em menor número do que E. coli. Não são exclusivamente de origem fecal, podem ser encontrados em outras fontes ambientais. Esporos de clostrídios podem sobreviver na água por muito mais tempo do que organismos do grupo coliforme e são bastante resistentes à desinfecção. Dessa forma, a presença dos mesmos em água desinfetada pode indicar deficiências no tratamento, ou ainda, que patogênicos resistentes à desinfecção podem ter sobrevivido e passado pelo tratamento. Devido sua persistência na água - significantemente maior do que patogênicos entéricos são importantes indicadores de contaminação remota, porém, não são recomendados como indicadores fecais nem para monitoramento de rotina em sistemas de tratamento e distribuição de água (OMS, 2002).

PAYMENT \& FRANCO (1993) estudaram C. perfringens e colifagos (somáticos e específicos) como indicadores de cistos de protozoários e de vírus, na verificação da eficiência de processos de tratamento de água. Os autores concluíram que ambos, C. perfringens e colifagos são bons indicadores. Entretanto, C. perfringens foi melhor indicador tanto da inativação de vírus e cistos, como da verificação da eficiência de processos de tratamento. Ainda, os métodos de detecção de C. perfringens são específicos e sensíveis. 
TYRRELL et al. (1995) avaliaram e compararam as taxas de inativação de populações selvagens de coliformes fecais, enterococos, C. perfringens, bacteriófagos específicos e somáticos em efluente secundário. Os desinfetantes usados foram cloro e ozônio. Coliformes fecais foram avaliados quanto à sua confiabilidade como índice de resposta viral aos tratamentos com cloro e ozônio. Sob as condições empregadas na pesquisa, os resultados obtidos indicaram que o indicador coliforme fecal é inadequado para prever resposta viral aos processos de cloração e ozonização. Verificou-se que C. perfringens foi relativamente insensivel à inativação por ambos desinfetantes, sendo que a concentração desse microrganismo ficou estável por prolongado período de tempo.

Atualmente uma constante preocupação para os sistemas produtores de água é a ocorrência de oocistos de Cryptosporidium, devido principalmente aos freqüentes surtos de doenças atribuídos a esses protozoários, à acentuada resistência dos mesmos às condições ambientais adversas e aos desinfetantes rotineiramente empregados para potabilizar água. A detecção de Cryptosporidium é um importante componente para o controle desse patógeno. No entanto, os métodos de detecção de Cryptosporidium em amostras hídricas são de difícil execução, requerem excessiva manipulação laboratorial, geram grande variabilidade de resultados e possibilidade de falsos-positivos (FRANCO, 2004). Assim, é grande o interesse na procura de organismos indicadores substitutos de Cryptosporidium e, que o exame desses possam ser rotineiros e confiáveis.

Esporos de C. perfringens têm sido sugeridos como possivel indicador alternativo ao Cryptosporidium e outros patogênicos altamente resistentes, devido à comprovada resistência desse indicador ao cloro, a outros desinfetantes e condições ambientais adversas. Com o auxílio de métodos simples de filtração em membrana ou tubos múltiplos, um meio seletivo e incubação anaeróbia, torna-se possivel exames de rotina da água para detectar C. perfringens (VENCZEL et al., 1997).

Os mesmos autores compararam a cinética de inativação de oocistos $C$. parvum e esporos de C. perfringens expostos a uma mistura de oxidantes 
(processo MIOX) e também ao hipoclorito de sódio (a dose usada foi de $5 \mathrm{mg} / \mathrm{L}$, para os dois desinfetantes) e temperatura de $25^{\circ} \mathrm{C}$. De maneira geral, a cinética de inativação dos dois microrganismos foi similar, e indicou potencial utilidade de C. perfringens como indicador de parasitas de veiculação hídrica altamente resistentes. Os autores advertiram, entretanto, que estudos adicionais com diferentes doses de MIOX são necessários sob variadas condições de qualidade de água.

\section{4 - Os desinfetantes empregados na presente pesquisa}

Cloro, ácido peracético, ozônio, e a combinação ozônio / cloro foram os processos de desinfecção empregados na pesquisa de Doutorado.

Uma breve revisão da literatura sobre o mecanismo de ação, a inativação de microrganismos, e a formação de subprodutos da desinfecção foi realizada conjuntamente para os desinfetantes cloro, ácido peracético e ozônio. A seguir, o processo combinado é descrito separadamente.

Aspectos gerais como: química básica, propriedades físico-químicas, geração dos oxidantes, considerações de projeto, bem como análise de custo foram suprimidos, com o objetivo de melhor direcionar a revisão para a temática abordada na pesquisa, além da existência de vasta literatura disponível sobre o assunto, inclusive, recentes pesquisas realizadas no Departamento de Hidráulica e Saneamento da EESC/ USP citadas no capítulo1.

\subsection{1 - Mecanismo de ação dos desinfetantes cloro, ácido peracético e ozônio}

"A ação do cloro como desinfetante envolve uma série de fatores, de maneira que não foi possivel até hoje se determinar com precisão sua atuação sobre as bactérias e outros microrganismos. Uma das teorias mais difundidas se refere à reação do ácido hipocloroso (HOCl) com um dos sistemas enzimáticos 
(possivelmente sobre triosefosfato dihidrogenase) que é essencial na oxidação da glucose, processo muito importante para o metabolismo celular bacteriano." "Comprovadamente o ácido hipocloroso exerce maior ação desinfetante que o ion hipoclorito ( $\mathrm{OCl})$, o que se explica pela maior facilidade de penetração do ácido através da parede celular, por ser este uma molécula pequena e neutra. $O$ ion hipoclorito por sua vez tem maior dificuldade em atravessar a parede celular $e$ atingir o sistema enzimático em função de sua carga negativa. Portanto, é possivel que a maior dificuldade na eliminação de formas esporuladas se deva à resistência a penetração do agente desinfetante pelo seu envoltório de proteção." "A necessidade de dosagens mais elevadas de cloro na inativação de vírus favorece a teoria de que a ação bactericida se dê por ação enzimática, sendo os virus desprovidos de enzimas, a sua destruição só é possivel por oxidação direta de matéria protéica, o que exige mais cloro” (ZARPELON \& RODRIGUES 2002).

De acordo com CAIRNS (1995), a cloração provoca a reação da molécula do desinfetante com alguma biomolécula crítica do microrganismo. Sendo que, vários fatores influenciam o sucesso da inativação microbiana, dentre os quais: a elevada dependência do $\mathrm{pH}$ das espécies de cloro $\mathrm{OCl}^{-}$e $\mathrm{HOCl}$; a natureza da superficie celular; o pH intracelular do organismo; o equilibrio entre as espécies de cloro; a temperatura, que influencia as taxas de reação química; e a difusão intracelular que influencia o acesso do desinfetante às biomoléculas críticas. Ainda, a habilidade que o cloro possui de sofrer transformações ao ocorrerem as reações de substituição e de oxidação, dificulta ainda mais a compreensão da química da desinfecção com cloro.

Enfim, a multiplicidade dos mecanismos de reações químicas, dos grupos funcionais reativos, do comportamento dos grupos funcionais das biomoléculas, a variabilidade dos grupos de microrganismos, da superfície celular e do estado fisiológico desses, são fatores que sugerem que durante a cloração não há um mecanismo comum de inativação para todos os microrganismos. Esse mecanismo varia também, conforme a dose de cloro e o pH extracelular no qual os microrganismos se encontram (CAIRNS, 1995).

O ácido peracético (APA), segundo JOLIVET-GOUGEON et al. (1995), provavelmente rompe ligações sulfidricas e sulfúricas nas enzimas, 
conseqüentemente, importantes componentes das membranas são quebrados por rompimento oxidativo. É também provável que o APA tenha capacidade de deslocar funções químicas de transporte da membrana por meio de ruptura ou deslocamento da parede celular, impedindo severamente a atividade celular.

Dentro da célula o APA também pode oxidar enzimas essenciais, prejudicando desse modo caminhos bioquímicos vitais, transporte ativo através das membranas, e os níveis de soluto dentro das células (BALDRY \& FRASER, 1989).

O mecanismo de ação do ozônio contra bactérias, vírus e protozoários é amplamente estudado por vários grupos de pesquisadores. Uma compilação desses estudos encontra-se no manual da USEPA (1999):

A inativação de bactérias pelo ozônio é atribuída a uma reação de oxidação (BRINGMANN4, 1954; CHANG5, 1971). O primeiro ataque parece ser na membrana bacteriana (GIESE \& CHRISTENSEN6, 1954) diretamente nas glicloproteínas ou glicolipídios (SCOTT \& LESCHER7, 1963) ou em certos aminoácidos, como o triptofan (GOLDSTEIN \& McDONAGH8, 1975), e ainda, interromper a atividade enzimática das bactérias. Além da membrana e da parede das células, o $\mathrm{O}_{3}$ pode agir no material nuclear. O ozônio é considerado responsável pela modificação tanto das purinas quanto das pirimidinas dos ácidos nucléicos (GIESE \& CHRISTENSEN, 1954; SCOTT \& LESCHER, 1963).

O primeiro local da ação para inativação de vírus é no capsídio viral (uma partícula viral completa, consistindo em RNA ou DNA, cercada por uma capa de proteína), particularmente suas proteínas (CRONHOLM 9 et al., 1976;

\footnotetext{
${ }^{4}$ BRINGMANN, G. 1954 - Determination of the lethal activity of chlorine and ozone on E. coli. Z. f., Hygiene. 139:130-139.

${ }^{5}$ CHANG, S.L. 1971 - Modern concept of disinfection. J. Sanit. Engin.Division. 97:689-707.

${ }^{6}$ GIESE, A.C. \& CHRISTENSEN, E. 1954 - Effects of ozone on organisms. Physiol. Zool. 27:101.

${ }^{7}$ SCOTT,D.B.M. \& LESHER,E.C. 1963 - Effect of ozone on survival and permeability of E. coli. J. Bacteriol. 85:567-576.

8 GOLDSTEIN, B.D. \& McDONAGH, E.M. 1975- Effect of ozone on cell membrane protein fluorescence in vitro studies utilizing the red cell membrane. Environ. Res. 9:179-186.

${ }^{9}$ CRONHOLM, L.S., et al. 1976. Enteric vírus survival in package plants and the upgrading of the small treatment plants using ozone. Research Report No.98, Water Resources Research Institute, University of Kentucky, Lexington, KY.
} 
RIESSER ${ }^{10}$, 1976). O ozônio parece modificar o capsídio viral usado para fixação na superficie das células. Altas concentrações de ozônio dissociam o capsídio completamente. O mecanismo de inativação do bacteriófago RNA $\mathrm{f}_{2}$ compreende a liberação do RNA desta partícula depois que sua camada protetora é quebrada em muitos pedaços (KIM11 et al., 1980). Esta constatação sugere que $\mathrm{o}_{3}$ desliga a proteína capsídio, libera o RNA e rompe a adsorção ao anfitrião pili. Além disso, o RNA desprotegido pode ser secundariamente inativado pelo desinfetante em questão, em uma taxa menor que a necessária para o caso do RNA dentro do bacteriófago intacto. O mecanismo de inativação do bacteriófago DNA $\mathrm{T}_{4}$ foi considerado bastante semelhante à inativação do RNA: a proteína capsídio é atacada, libera ácido nucléico e o DNA é inativado (SPROUL ${ }^{12}$ et al. 1982). Em contraste, pesquisas com o vírus de mosaico do tabaco (VMT) mostraram que o ozônio tem um efeito específico sobre o RNA. O ozônio foi considerado o responsável pelo ataque à camada de proteína e ao RNA. O RNA danificado liga-se com aminoácidos da camada de proteína. O VMT perde sua infectividade por causa da perda da sua capa proteica.

A observação microscópica da inativação dos protozoários Naegleria e Acanthamoeba mostrou que eles foram rapidamente destruídos e a membrana celular danificada com o ozônio. O ozônio afetou as ligações nos cistos de Naegleria gruberi (PERRINE13 et al., 1984). Dependendo das condições da ozonização, estas ligações são completamente removidas ou parcialmente destruídas. Quanto aos cistos de Giardia muris a hipótese é que o ozônio afeta inicialmente a parede dos cistos, tornando-os mais permeáveis (WICKRAMANAYAKE, 1984). Subseqüentemente, o ozônio aquoso penetra no cisto e danifica a membrana do plasma, e penetração adicional de $\mathrm{O}_{3}$ prejudica o núcleo, os ribossomos, e outros componentes estruturais.

\footnotetext{
${ }^{10}$ RIESSER, V.W., et al.1976. Possible mechanisms of poliovirus inactivation by ozone. Forum on Ozone Disinfection, E. G. Fochtman, R.G. Rice, and M.E. Browning (editors), pp.186-192, International Ozone Institute, Syracuse, NY.

${ }^{11}$ KIM, C.K., et al. 1980. Mechanisms of ozone inactivation of bacteriophage f2. Appl. Environ. Microbiol. 39:210-218.

${ }^{12}$ SPROUL, O.J., et al. 1982. The mechanism of ozone inactivation of wastewater viruses. Water Sci. Technol. 14:303-314.

${ }^{13}$ PERRINE, D., et al. 1984. Actiond l' Ozone sur les trophozoites d' amibes libres pathogens ou non. Bull Soc.Frnac. Parasitol. 3:81.
} 


\subsection{2 - Inativação de patogênicos e eficácia da desinfecção com cloro, ácido peracético e ozônio}

Durante a cloração a inativação microbiana é influenciada por variações da sensibilidade dos microrganismos - em geral, a ordem crescente de dificuldade de desinfecção com cloro compreende bactérias, vírus e protozoários -, e fatores ambientais tais como $\mathrm{pH}$, tempo de contato, mistura, turbidez, substâncias interferentes e concentração de cloro disponível. Em geral, os niveis de inativação de patogênicos mais elevados são obtidos com alta concentração de cloro residual, longo tempo de contato, temperatura elevada, mistura eficiente, turbidez e pH baixos, e ausência de substâncias interferentes [CAIRNS (1995); USEPA, (1999)].

Ainda, a cloração de efluentes contendo amônia forma cloraminas, a qual, usada como desinfetante primário resulta em drástica redução das taxas de inativação microbiana. Experimentos de desinfecção de culturas de laboratório do bacteriófago MS2 com cloraminas produziram inativação menor que $1 \mathrm{log}$, após 4 horas de contato, $2 \mathrm{mg} / \mathrm{L}$ de cloraminas, $15^{\circ} \mathrm{C}$ e $\mathrm{pH} 7$ (CAIRNS, 1995).

RICE et al. (1996) realizaram estudo de inativação de esporos aeróbios selvagens com hipoclorito de sódio. As condições principais do experimento foram: batelada, agitação constante, concentração média de esporos presentes na água do rio de $15.250 \mathrm{UFC} / 100 \mathrm{~mL}$, pH final de 6.86 e temperatura de $23^{\circ} \mathrm{C}$. Após 65 min de exposição ocorreu redução aproximada de 2-log e o CT foi de aproximadamente $114 \mathrm{mg} \cdot \mathrm{min} / \mathrm{L} \quad(\mathrm{C}=$ cloro total disponível). Após 180 min ocorreu 3 log de redução e o CT foi de 315 mg.min/L. Em estudos prévios de inativação empregando culturas puras de esporos de $B$. subtilis, realizados sob condições similares de $\mathrm{pH}$ e temperatura, foi reportado 3-log de redução após $5 \mathrm{~min}$ de exposição e $100 \mathrm{mg} / \mathrm{L}$ de cloro disponível, resultando num CT de $500 \mathrm{mg} / \mathrm{L}$. As culturas puras foram mais resistentes à inativação, e, tal fato foi atribuído à etapa de preparação dos esporos, provenientes de culturas puras, em que são selecionados os esporos mais resistentes na etapa de purificação. Enquanto que, sob condições naturais, os esporos selvagens 
devem existir em diferentes estágios de maturidade e dormência metabólica, além do estresse ambiental a que estão constantemente sujeitos.

Os autores ressaltam que ao se comparar valores CT da literatura devese levar em conta os diferentes oxidantes e microrganismos empregados no estudo, outras variáveis intrínsecas ao experimento, além do próprio método de se calcular o produto CT. Ademais, quando se avalia a inativação de protozoários, os métodos usados para se determinar a viabilidade de cistos e oocistos é outra importante consideração.

O APA possui amplo espectro de atividade antimicrobiana. Diversos estudos a esse respeito encontram-se disponiveis na literatura.

BALDRY (1982) comparou as propriedades antimicrobianas de soluções aquosas de ácido peracético e peróxido de hidrogênio. O ácido peracético exibiu excelentes propriedades antimicrobianas, especialmente sob condições ácidas. Fatores de redução da ordem de $10^{6}$ no número de bactérias vegetativas foram obtidos com 1 minuto de tempo de contato a $25^{\circ} \mathrm{C}$, usando solução contendo 1,3 m.mol/L de ácido peracético. Inativações de bactérias formadoras de esporos e leveduras também ocorreram. No entanto, como esperado, dosagens mais elevadas foram requeridas para inativar bactérias formadoras de esporos do que vegetativas. Por exemplo, em um teste realizado em condições de $\mathrm{pH}$ 5,0 , a dosagem esporicida foi de $13 \mathrm{~m} . \mathrm{mol} / \mathrm{L}$ para 60 minutos de contato, enquanto a dosagem bactericida foi de 0,13 m.mol/L para 30 minutos.

BALDRY \& FRENCH (1989) realizaram experimentos de desinfecção com produtos à base de ácido peracético. Empregaram em laboratório, culturas puras de microrganismos para avaliar as propriedades virucidas e bactericidas desses produtos e obtiveram os seguintes resultados: $25 \mathrm{mg} / \mathrm{L}$ de APA e 5 minutos de contato, foram suficientes para inativações maiores do que 99,999\% de E. coli e S. faecalis. Mesmo na presença de elevada concentração de matéria orgânica, proveniente do meio de cultura das bactérias, dosagem de $100 \mathrm{mg} / \mathrm{dm}^{3}$ de APA e 5 minutos de contato foram requeridos para inativação de $5 \log (99,999 \%)$ dessas bactérias.

A concentração de APA efetiva para inativação dos bacteriófagos MS2 e $\phi$ 174 em água desmineralizada foram respectivamente de 15 e $30 \mathrm{mg} / \mathrm{dm}^{3}$, o 
que resultou em inativações maiores do que $4 \log (99,99 \%)$ em 5 minutos de contato. Na presença de matéria orgânica, a dosagem de aproximadamente $100 \mathrm{mg} / \mathrm{dm}^{3}$ foi efetiva para os bacteriófagos.

Os autores obtiveram ainda que a atividade do APA foi maior sob condição neutra ou medianamente ácida. Dosagens muito mais elevadas de APA, de 750 a $1500 \mathrm{mg} / \mathrm{dm}^{3}$, foram requeridas para inativar 99,99\% de Poliovirus em 15 minutos.

Vários biocidas comumente usados em processos de desinfecção como agentes bactericidas e fungicidas foram testados quanto à sua atividade na inativação de colifagos MS2 e K. O MS2 foi resistente à maioria dos biocidas. Somente os desinfetantes glutaraldeído $(0,5 \%)$ e ácido peracético (1\%) foram eficazes para a inativação de $4 \mathrm{log}$ em 20 minutos de contato. Em contraste, o fago $\mathrm{K}$ foi mais sensivel à maioria dos biocidas (RUSSEL et al., 1994).

BALDRY et al. (1995) realizaram experimentos no Brasil e na Itália, em laboratório e em escala real. Os resultados mostraram que o ácido peracético foi um bom desinfetante (melhor do que o hipoclorito de sódio) para o tratamento de esgoto em países de climas tropical e temperado quente. O ácido peracético demonstrou ser efetivo contra o Vibrio cholera, tendo sua atividade melhorada em temperaturas mais elevadas. Assim, ele se torna provável alternativa para tratamento de esgoto e para controle da cólera em países de clima quente.

Segundo SÁNCHEZ-RUIZ et al., (1995) as vantagens potenciais dos produtos que têm por base o ácido peracético, em detrimento de outros desinfetantes químicos, são a falta de efeitos adversos ao ambiente e a rápida evolução dos mesmos em subprodutos inócuos e facilmente biodegradáveis, tais como ácido acético e oxigênio ativo.

GASI et al., (1995) desinfetaram efluente de lodos ativados empregando ácido peracético em dosagem de $5 \mathrm{mg} / \mathrm{L}$ e tempo de contato de 27 minutos, obtendo remoção de 99,98\%, 99,40\% e 96\% de coliformes totais, coliformes fecais e colifagos, respectivamente. Obtiveram também que a concentração de oxigênio dissolvido no efluente da câmara de contato manteve-se acima da concentração de saturação, evidenciando a decomposição do peróxido de 
hidrogênio em oxigênio e água. Além disso, verificaram que a aplicação de ácido peracético oxida a matéria orgânica, removendo em média 22,5\% de DBO do efluente de lodos ativados estudado. Os ensaios de toxicidade do efluente desinfetado indicaram elevada toxicidade para os microrganismos aquáticos testados - Daphinia similis, Brachydario rerio e Photobacterium phosphorium.

RAJALA-MUSTONEN et al., (1997) estudaram a efetividade do ácido peracético na inativação de colifagos em esgoto e obtiveram os seguintes resultados: com concentração de $50 \mathrm{mg} / \mathrm{L}$ a inativação foi maior do que $5 \mathrm{log}$ para o DNA do fago, e redução maior do que $3 \mathrm{log}$ foi obtida para o RNA do fago, depois de 10 minutos de tempo de contato. Porém, quando a turbidez da água aumentou de 2 para 10 uT, a redução foi de uma ou duas ordens de magnitude menor. Para o RNA-fago, por exemplo, a redução foi 10 vezes mais baixa quando a turbidez aumentou de 2 para 8 uT.

SOUZA (2000) estudou a influência da cor e da turbidez em ensaios de desinfecção empregando ácido peracético e obteve para a dosagem aplicada de $3,5 \mathrm{mg} / \mathrm{L}$ e 15 minutos de contato, inativação de E. coli maior do que $5 \log$ $(99,999 \%)$ para todos os ensaios, independente das características de cor (5 $\mathrm{uH}$ e $20 \mathrm{uH}$ ) e turbidez ( 2 uT e 50 uT) da água utilizada.

Os experimentos de desinfecção realizados com APA confirmam sua elevada atividade contra largo espectro de organismos. Em geral, concentrações mais elevadas de APA são requeridas para a ação esporicida do que bactericida e fungicida (BLOCK, 2001).

Também KITIS (2003) comenta que o APA é um forte desinfetante com largo espectro de atividade antimicrobiana, é usado em várias indústrias incluindo as de processamento de alimentos, bebidas, médica, farmacêutica, têxtil, de polpa e de papel. Devido às suas propriedades bactericida, virucida, fungicida e esporicida, o uso do ácido peracético como desinfetante de esgotos domésticos recebe cada vez mais atenção em países como Inglaterra, Finlândia, Itália, Brasil e Canadá.

VESCHETTI et al. (2002) realizaram estudo comparativo entre ácido peracético e hipoclorito de sódio para desinfecção de esgoto sanitário, proveniente de uma estação de tratamento de lodos ativados convencional. 
Foram avaliados a influência da concentração inicial de ácido peracético $(0,5$ 4,0 mg/L) e do tempo de contato (8 - 38 minutos) na inativação dos microrganismos - coliforme total, coliforme fecal, Streptococcus faecalis, Escherichia coli, Pseudomonas sp., Salmonella sp. e bacteriófagos de E. coli. Os autores avaliaram também as concentrações residuais dos biocidas e formação de compostos orgânicos halogenados (AOXs). O efeito biocida do ácido peracético na inativação de coliformes total e fecal, E. coli, Pseudomonas sp. e Salmonella sp., foi similar ao obtido pelo hipoclorito de sódio, entretanto o ácido peracético foi menos eficiente do que o cloro na redução de Streptococcus faecalis e bacteriófagos. Em ambos os casos, consideráveis concentrações residuais dos dois biocidas foram detectadas ao final do tempo de contato. Nenhuma variação significativa do conteúdo de AOX foi detectada no efluente tratado com ácido peracético, no entanto, o incremento de tais compostos foi verificado em efluentes tratados com cloro.

Para desinfecção de esgotos, o ácido peracético é alternativa interessante, devido aos atributos de facilidade de implementação (sem a necessidade de extensivo custo de investimento) largo espectro de atividade, mesmo na presença de matéria orgânica heterogênea, ausência de residual ou subprodutos tóxicos e/ou mutagênicos, desnecessária descloração, baixa dependência do $\mathrm{pH}$, curto tempo de contato e efetividade de desinfecção de efluentes primários e secundários (KITIS, 2003).

De acordo com o mesmo autor as desvantagens associadas à desinfecção de esgoto com ácido peracético são o aumento do conteúdo orgânico do efluente devido ao ácido acético, advindo daí a potencialidade de recrescimento microbiano (o ácido acético além de estar presente na mistura é também formado após a decomposição do ácido peracético). Outro inconveniente ao uso do APA é seu custo mais elevado em comparação ao cloro, devido particularmente à limitada capacidade de produção do APA em todo o mundo. O custo do produto na Europa (solução de 12\%) é de cerca de US\$ 3 gal-1 $^{-1}$ (US\$ $0.08 \mathrm{~L}^{-1}$ ), aproximadamente de quatro a cinco vezes o custo do hipoclorito de sódio nos Estados Unidos. Entretanto, o autor avalia que, se 
a demanda pelo APA aumentar, especialmente na indústria de tratamento de águas residuárias, o seu custo tende a diminuir.

A utilização do APA em água de abastecimento poderá ter maior aplicação como pré-desinfetante para melhoria da qualidade da água bruta. Com isso, reduz-se a concentração de patógenos, e por ser oxidante, a de matéria orgânica, reduzindo por sua vez o potencial de formação de subprodutos clorados quando se emprega o cloro para desinfecção ou na manutenção de residual desinfetante (DANIEL, 2001).

Também, o ozônio apresenta elevado poder germicida na inativação de grande variedade de organismos patogênicos, incluindo bactérias, vírus e protozoários. Em vista disso, o $\mathrm{O}_{3}$ pode ser usado para proporcionar alto grau de inativação, embora, não é interessante para ser usado como desinfetante secundário porque sua concentração residual decai muito rapidamente (USEPA, 1999).

Segundo LANGLAIS (1991) dentre as bactérias vegetativas a E. coli é uma das mais sensiveis à inativação pelo ozônio, enquanto que, cocos grampositivos (Staphylococcus e Streptococcus), bacilos gram-positivos (Bacillus), e Mycobacteria estão entre as espécies mais resistentes. Ainda, as formas esporuladas são sempre mais resistentes ao ozônio que as formas vegetativas.

Em relação aos vírus, segundo o mesmo autor, esses são, em geral, muito mais resistentes ao ozônio do que bactérias vegetativas, porém não mais resistentes que as bactérias esporuladas, por exemplo, Mycobacteria. Entretanto, os fagos são considerados bastante sensiveis ao ozônio.

Por sua vez, os cistos de protozoários são reconhecidos pela literatura como muito mais resistentes do que as bactérias vegetativas e virus.

WICKRAMANAYAKE et al. (1984) realizaram estudo de inativação de cistos de Giardia lamblia com ozônio. O experimento foi feito em batelada, em água com pH 7.0 e temperaturas de 5 e $25^{\circ} \mathrm{C}$. Para $99 \%$ de inativação dos cistos foram empregados $\mathrm{CT}$ de 0.53 e $0.17 \mathrm{mg} \cdot \mathrm{min} / \mathrm{L}$, para as temperaturas de 5 e $25^{\circ} \mathrm{C}$ respectivamente. Os valores de CT obtidos para desinfecção com o ozônio foram significantemente mais baixos do que os valores reportados na literatura para desinfecção com cloro. 
$\mathrm{Na}$ Tabela 3.4 são apresentados valores de CT da literatura para inativação de organismos com ozônio e cloro.

Tabela 3.4 - Dados comparativos de CT para 99\% de inativação de alguns organismos com ozônio e cloro.

\begin{tabular}{|c|c|c|c|c|c|c|c|}
\hline Organismo & Desinfetante & $\mathrm{pH}$ & $\mathrm{T}\left({ }^{\circ} \mathrm{C}\right)$ & $\begin{array}{c}\text { Dosagem } \\
(\mathrm{mg} / \mathrm{L})\end{array}$ & $\begin{array}{c}\text { Tempo } \\
\text { (min) }\end{array}$ & $\begin{array}{c}\mathrm{CT} \\
\text { (mg.min/L) }\end{array}$ & Referência \\
\hline Cistos de $G$. & Ozônio & 7,0 & 25 & $0,03-0,15$ & $5,5-1,06$ & 0,17 & Wickramanayake et al. \\
\hline \multirow[t]{5}{*}{ lamblia } & & 7,0 & 5 & $0,11-0,48$ & $5,0-0,94$ & 0,53 & (1984) \\
\hline & Cloro & 7,0 & 25 & 1,5 & $<10$ & $<15$ & Wickramanayake et al. \\
\hline & & 7,0 & 5 & $2,0-4,0$ & $45-40$ & $\sim 125$ & (1984) \\
\hline & & & & & & & Jarrol14 et al. (1981) \\
\hline & & & & & & & Jarrol et al. (1981) \\
\hline \multirow[t]{3}{*}{ Poliovirus 1} & Ozônio & 7,2 & 20 & 0,15 & 0,5 & 0,08 & Roy 15 et al.(1982) \\
\hline & & 7,2 & 5 & 0,15 & 1,45 & 0,22 & Roy et al. (1982) \\
\hline & Cloro & 6 & 5 & 0,5 & 4,0 & 2,0 & Scarpino16 et al. (1974) \\
\hline \multirow[t]{2}{*}{ E. coli } & Ozônio & 7,2 & 1 & 0,065 & 0,33 & 0,02 & Katzenelson 17 et al. (1974) \\
\hline & Cloro & 6 & 5 & 0,1 & 0,4 & 0,04 & Scarpino et al. (1974) \\
\hline
\end{tabular}

Fonte: WICKRAMANAYAKE et al. (1984).

Segundo observação dos autores, quando mais de uma dosagem foi usada, o CT médio foi estimado pelo número de amostras testadas. Os dados não são exatamente comparáveis, devido a pequenas variações no $\mathrm{pH}$ e temperatura, entretanto, tais variações não depreciam a validade da comparação.

Os cistos de G. lamblia foram cerca de duas vezes mais resistentes ao ozônio que Poliovirus 1 , em $\mathrm{pH}$ neutro e temperatura de 5 e $25^{\circ} \mathrm{C}$. Nos experimentos com cloro os cistos foram cerca de 60 vezes mais resistentes que os virus, a $5^{\circ} \mathrm{C}$. Os cistos de G. lamblia foram mais resistentes que E. coli ao

${ }^{14}$ JARROL, E.A., et al., 1981. Effect of chlorine on Giardia lamblia cysts viability. Appl. Environ. Microbiol. 41:483-487.

${ }^{15}$ ROY, D., et al., 1982. Comparative inactivation of six enteroviruses by ozone. J. Am. Water Works Assoc. 74:660-664.

${ }^{16}$ SCARPINO, P.V., et al., 1974. Effectiveness of hypochlorous acid and hypochlorite ion in destruction of viruses and bacteria. P. 359-368. In A.J. rubin (ed.) Chemistry of water supply, treatment, and distribution. Ann Arbor Science Publishers, Woburn. Mass.

${ }^{17}$ KATZENELSON, E., et al., 1974. Inactivation kinectics of viruses and bacteria in water by use of ozone. J. Am. Water Works Assoc. 66:725-729. 
ozônio e ao cloro, cerca de 1 e 3 ordens de magnitude, respectivamente, a baixas temperaturas. Ao se empregar ozônio, a estreita faixa de valores de CT para inativação de cistos, virus e bactérias, demonstra que as diferenças de resistência entre esses organismos são menores em relação ao ozônio do que ao cloro. Os dados apresentados na Tabela 3.4 também indicaram que para ambas temperaturas $\left(5\right.$ e $\left.25^{\circ} \mathrm{C}\right)$ o ozônio foi muito mais efetivo do que o cloro na inativação de G. lamblia.

Em relação à temperatura, os resultados do estudo de WICKRAMANAYAKE et al. (1984) indicaram que a resistência dos cistos de $G$. lamblia ao ozônio foi cerca de três vezes maior à $5^{\circ} \mathrm{C}$ do que à $25^{\circ} \mathrm{C}$. Baseado nos dados da Tabela 3.4 concluiu-se que para a inativação de G. lamblia o ozônio, comparado ao cloro, é menos afetado por variações na temperatura.

A eficiência do ozônio para a inativação de oocistos de Cryptosporidium é apresentada na Tabela 3.5 (USEPA, 1999), em que são sumarizados os valores de CT obtidos por diversos pesquisadores, para 99\% de inativação desse organismo.

Os resultados apresentados na Tabela 3.5 indicaram que o $\mathrm{O}_{3}$ é um dos desinfetantes mais efetivos para controlar Cryptosporidium, e que Cryptosporidium muris pode ser ligeiramente mais resistente à ozonização que o Cryptosporidium parvum.

De acordo com USEPA (1999) a variedade dos valores CT para obtenção do mesmo nivel de inativação de Cryptosporidium deve-se, principalmente, aos diferentes métodos de detecção de Cryptosporidium, pH, temperatura, e condições de aplicação do ozônio. 
Tabela 3.5 - Resumo dos valores de CT para inativação de $99 \%$ de oocistos de Cryptosporidium com ozônio.

\begin{tabular}{|c|c|c|c|c|c|c|}
\hline Espécie & Protocolo & $\begin{array}{l}\text { Ozônio } \\
\text { residual } \\
(\mathrm{mg} / \mathrm{L})\end{array}$ & $\begin{array}{l}\text { Tempo } \\
\text { de } \\
\text { contato } \\
\text { (min) }\end{array}$ & $\begin{array}{c}\text { Temperatura } \\
\left({ }^{\circ} \mathrm{C}\right)\end{array}$ & $\begin{array}{c}\mathrm{CT} \\
\text { (mg.min/L) }\end{array}$ & Referência \\
\hline C. baileyi & $\begin{array}{c}\text { Líquido - } \\
\text { batelada ozônio- } \\
\text { batelada } \\
\text { modificado }\end{array}$ & 0,6 e 0,8 & 4 & 25 & $2,4-3,2$ & $\begin{array}{c}\text { Langlais }^{18} \text { et al., } \\
1990\end{array}$ \\
\hline C. muris & Fluxo contínuo & & & $22-25$ & 7,8 & Owens ${ }^{19}$ et al., 1994 \\
\hline C. parvum & $\begin{array}{l}\text { Liquido-batelada } \\
\text { Ozônio-batelada }\end{array}$ & $\begin{array}{l}0,50 \\
0,50\end{array}$ & $\begin{array}{l}18 \\
7,8\end{array}$ & $\begin{array}{c}7 \\
22\end{array}$ & $\begin{array}{l}9,0 \\
3,9\end{array}$ & Finch $^{20}$ et al., 1994 \\
\hline C. parvum & $\begin{array}{l}\text { Líquido-batelada } \\
\text { Ozônio-batelada }\end{array}$ & $\begin{array}{l}0,77 \\
0,51\end{array}$ & $\begin{array}{l}6 \\
8\end{array}$ & ambiente & $\begin{array}{c}4,6 \\
4\end{array}$ & Peeters $^{21}$ et al., 1989 \\
\hline C. parvum & $\begin{array}{l}\text { Líquido-batelada } \\
\text { Ozônio-fluxo } \\
\text { contínuo }\end{array}$ & 1,0 & 5 e 10 & 25 & $5-10$ & Korich et al., 1990 \\
\hline C. parvum & Fluxo contínuo & & & $22-25$ & 5,5 & Owens et al., 1994 \\
\hline
\end{tabular}

Fonte: Adaptado de USEPA (1999).

${ }^{18}$ LANGLAIS, B., et al., 1990. New developments: ozone in water and wastewater treatment. The CT value concept for evaluation of disinfection process efficiency; particular case of ozonation for inactivation of some protozoa, free-living amoeba and Cryptosporidium. Presented at the Int. Ozone Assn. Pan-American Conference, Shreveport, Louisiana, March 27-29.

${ }^{19}$ OWENS, J. H., et al., 1994. Pilot-scale ozone inactivation of Cryptosporidium and Giardia. Conference proceedings, Water Quality Technology Conference, Part II, San Francisco, CA.

${ }^{20}$ FINCH, G.R., et al., 1994. Ozone and chlorine inactivation of Cryptosporidium. Conference proceedings, water Quality Technology Conference, Part II, San Francisco, CA.

${ }^{21}$ PEETERS, J.E. et al. 1989. Effect of disinfection of drinking water with ozone or chlorine dioxide on survival of Cryptosporidium parvum oocysts. Appl. Environ. Microbiol. 55(6):1519-1522. 
Também LANGLAIS (1991) afirma que existem limitações quanto à aplicação dos valores CT reportados na literatura. Dentre eles, a sensibilidade dos microrganismos aos diferentes desinfetantes varia amplamente, dependendo do tipo de microrganismo considerado, e do desinfetante usado. É conveniente recordar ainda que as condições experimentais (em particular, as características físico-químicas da água) são fatores que influenciam sobremaneira a ação desinfetante do ozônio.

\subsection{3 - Subprodutos da desinfecção com cloro, ácido peracético e ozônio}

A cloração está associada numerosos subprodutos. As classes desses compostos incluem: THMs, ácidos haloacéticos (AHAs), halocetonitrilas, halopicrin, cloreto e brometo de cianogênio, cloral hidrato, MX, e outros. Embora, esses sejam apenas uma pequena porcentagem dos haletos orgânicos totais (TOX), o que indica que há vários outros subprodutos orgânicos halogenados que não são detectados. Os THMs e HAAs são considerados os principais subprodutos associados com o cloro e os Mx são considerados os principais mutagênicos (determinados pelo teste Ames).

Segundo SINGER (1999), quando o cloro é adicionado à água bruta, ele reage com a MON presente na água e pode formar, clorofórmio $\left(\mathrm{CHCl}_{3}\right)$, ácidos mono, di, e tricloroacétcio (ClAA, $\mathrm{Cl}_{2} \mathrm{AA}$ e $\left.\mathrm{Cl}_{3} \mathrm{AA}\right)$, e outros subprodutos clorados. Se a água contém brometo, o cloro oxida o brometo a ácido hipobromoso, o qual torna a reagir com a MON e produz, em contrapartida, os subprodutos clorados brominados, como bromofórmio $\left(\mathrm{CHBr}_{3}\right)$, ácidos acéticos brominados (BrAA, $\mathrm{Br}_{2} \mathrm{AA}, \mathrm{Br}_{3} \mathrm{AA}$ ) e outros subprodutos brominados. Enfim, a adição de cloro à água contendo MON e brometo pode levar à formação dos seguintes subprodutos:

$$
\begin{gathered}
\mathrm{HOCl}+\mathrm{Br}^{-}+\mathrm{MON} \Rightarrow \mathrm{CHCl}_{3}+\mathrm{CHBrCl}_{2}+\mathrm{CHBr}_{2} \mathrm{Cl}+\mathrm{CHBr}_{3}+ \\
\mathrm{ClAA}+\mathrm{Cl}_{2} \mathrm{AA}+\mathrm{Cl}_{3} \mathrm{AA}+\mathrm{BrAA}+\mathrm{Br}_{2} \mathrm{AA}+ \\
\mathrm{Br}_{3} \mathrm{AA}+\mathrm{BrClAA}+\mathrm{BrCl}_{2} \mathrm{AA}+\mathrm{Br}_{2} \mathrm{ClAA}
\end{gathered}
$$

Dentre os fatores que afetam a formação dos subprodutos halogenados estão: tipo e concentração da MON, espécie e dosagem de cloro, tempo de 
contato, concentração de brometo, $\mathrm{pH}$, concentração de nitrogênio orgânico e temperatura. O nitrogênio orgânico influencia sobremaneira a formação de halocetonitrilas, halopicrins, e haletos de cianogênio (USEPA, 1999).

SINGER (1999) discutiu o impacto da MON na formação de subprodutos da cloração. No estudo, usou material orgânico hidrofóbico extraído de águas naturais. A formação de THMs e AHAs foi diretamente proporcional à concentração de carbono orgâncio total (COT) na solução sintétcia preparada com diferentes extratos hidrofóbicos. O mesmo comportamento também foi observado para a formação de outros subprodutos. O autor sugere que a desinfecção com cloro deve ser praticada após os processos de pré-tratamento, como coagulação e clarificação, para remoção prévia dos precursores (substâncias húmicas).

WILLIAMS et al. (1997) determinaram os subprodutos da desinfecção com cloro em uma ETA. Examinaram também, os efeitos de outros desinfetantes aplicados (cloramina e ozônio), da variação sazonal (verão e inverno) e da variação espacial (estação de tratamento e sistema de distribuição). Os principais subprodutos detectados em todas as amostras de água tratada foram clorofórmio, ácido dicloroacético e tricloroacétcio. A concentração total de ácidos haloacéticos freqüentemente igualou ou excedeu a concentração de TTHMs. Halocetonitrilas, halopropanonas, cloral hidrato e cloropicrin foram usualmente detectados nas amostras de água tratada, porém em concentrações mais baixas. Os niveis de TTHM foram mais elevados no verão do que no inverno e aumentou no sistema de distribuição para os três processos de tratamento.

KIM et al. (1997) estudaram em escala de laboratório a formação de subprodutos da cloração e da ozonização, em águas contaminadas com traços de compostos orgânicos. Foram empregados 16 compostos orgânicos voláteis e 4 compostos fenólicos. Os subprodutos foram analisados por cromatografia gasosa/ espectrometria de massa. A cloração produziu diclorobenzeno a partir do benzeno, etilbenzeno e estireno. Os compostos 1,2-dicloroetano, 1,2 dicloropropano e fenol produziram 1,1,1-tricloroetano, clorofórmio e clorofenol, 
respectivamente. A ozonização modificou o bromofórmio para dibromometano e, benzaldeído foi produzido a partir do estireno.

A aplicabilidade do APA para o tratamento de águas de abastecimento, processos industrias, especialmente, indústrias alimentícias e águas residuárias, cresceu muito devido às restrições aos compostos organoclorados originados pelos desinfetantes à base de cloro. $O$ ácido peracético não forma compostos halogenados absorviveis (AOX), DEGUSSA (2003).

O APA não é classificado como carcinogênico por instituições internacionais tais como a Agência Internacional de Pesquisa sobre o Câncer (IARC), a EPA, o Programa Nacional Americano de Toxicologia, dentre outras. Segundo essas instituições o APA não pode ser considerado carcinogênico baseado nos dados disponiveis até o presente, os quais são inconclusivos e deficientes (BLOCK, 2001).

O primeiro, e um dos poucos estudos sobre o potencial carcinogênico do APA foi publicado por BOCK 22 et al. (1975) apud BLOCK (2001). Neste estudo, foi aplicado sobre a pele de camundongos (30 fêmeas), 5 vezes por semana, 0,2 mL de APA $1 \%$ em acetona ou $2 \%$ de APA em água. Um grupo controle recebeu volume igual de água sobre a pele. Nenhum dos camundongos do grupo do APA adquiriu câncer de pele. Após 26 semanas, 3 dos 30 camundongos tiveram "tumores de pele", comparativamente com nenhum caso dentre os 30 camundongos do grupo controle. Nenhum camundongo adicional apresentou lesões até o final do experimento, após 66 semanas. Devido não ter sido identificada a morfologia celular dos tumores de pele, os resultados são dificeis de serem interpretados. Tais lesões podem ter sido resultado apenas de irritações no tecido superficial da pele devido à constante aplicação de substância química à mesma.

Segundo BLOCK (2001), esse estudo é considerado simples, contém uma série de deficiências científicas e não encontra na EPA ou outra agência reguladora, padrão necessário para um estudo carcinogênico. Dentre as deficiências estão a falta de estudo histopatológico confirmatório dos tumores de pele, número insuficiente de animais, uso de somente um sexo de 
camundongos e menor duração (66 semanas) do que a normalmente requerida para esse tipo de experimento (104 semanas).

Ainda, no estudo de BOCK 22 et al. (1975) apud BLOCK (2001), foi incluída uma avaliação paralela sobre o potencial promotor de tumores do APA. Nessa parte do estudo, grupos de 30 camundongos (30 fêmeas) foram expostos unicamente a um potente agente carcinogênico, o 7,12-dimetilbenzantraceno (DMBA). Três semanas mais tarde, os camundongos foram tratados 5 vezes por semana, durante 6 semanas, com 0,2 mL de uma solução aquosa de APA a $0,3 \%, 1,0 \%$ e 3,0\%. Um grupo controle tratado com DMBA recebeu água por 66 semanas, e nenhum desenvolveu câncer ou tumores de pele. Cinco dos 30 animais do grupo que recebeu APA a 3\% por 66 semanas, desenvolveram câncer de pele sendo que 24 dos 30 apresentaram tumores de pele. Um dos 30 animais que receberam APA a 1\% teve câncer de pele, e 8 deles apresentaram tumores de pele. Nenhum dos animais do grupo que recebeu APA a 0,3\% teve câncer, porém, 2 dos 30 apresentaram tumores. Nem os tumores nem o câncer foram especificamente diagnosticados. Os autores concluíram que o APA pode ser um promotor de tumor e que a exposição crônica das pessoas a um potente agente carcinogênico, tal como o DMBA, juntamente com elevadas concentrações de APA é extremamente desaconselhável. No entanto, de acordo com os próprios autores, a relevância desses resultados para seres humanos é questionável.

MONARCA et al. (2004) avaliaram a formação de compostos tóxicos e genotóxicos em água superficial destinada ao consumo, após desinfecção com hipoclorito de sódio, dióxido de cloro e ácido peracético. Os biocidas foram adicionados em água pré-filtrada (escala piloto), continuamente, por 20 dias. Durante os experimentos foram realizados testes in vivo (em plantas, peixes e moluscos) e, in vitro (em bactérias, leveduras e células humanas), para avaliar a formação de subprodutos genotóxicos. Para identificar os subprodutos foi usada técnica de cromatografia gasosa e espectrometria de massa (GC/MS), bem como análises microbiológicas para testar a atividade biocida dos desinfetantes e análises químicas para avaliar a qualidade da água.

${ }^{22}$ BOCK F.G., et al., 1975. Cocarcinogenicity of peroxi compounds. J.Natl Cancer Inst., 55:1359-1361. 
Os níveis mais elevados de subprodutos foram detectados na água desinfetada com $\mathrm{NaClO}$, enquanto que os mais baixos, na água desinfetada com APA. No entanto, a atividade bactericida do APA foi a mais baixa dentre os desinfetantes empregados. Segundo nota dos autores, experimentos adicionais em escala piloto e escala real, usando diferentes fontes de água e concentrações mais elevadas de APA, permitiram, posteriormente, melhor avaliação deste desinfetante.

$\mathrm{Na}$ Tabela 3.6 estão sumarizados os subprodutos detectados pelas análises de cromatografia e espectrometria de massa, com os três desinfetantes usados por MONARCA et al. (2004).

Tabela 3.6 - Subprodutos identificados por cromatografia gasosa e espectrometria de massa na água desinfetada com $\mathrm{NaClO}, \mathrm{ClO}_{2}$ e APA.

\begin{tabular}{llll}
\hline \multirow{2}{*}{ SPDs halogenados } & \multicolumn{2}{c}{$\mathrm{ClO}_{2}$} & APA \\
\cline { 2 - 3 } $\begin{array}{lll}\text { Bromofórmio } \\
\text { Ácido dicloroacético }\end{array}$ & \multicolumn{1}{c}{ SPDs halogenados } & SPDs não-halogenados & SPDs não halogenados \\
Ácido dibromoacético & Ácido dibromoacético & Heptanal & Nexanal \\
5-metil-2-furancarboxialdeido & 4,4-dibromo-2-butanona & Nonanal & Decanal \\
3-acetil-dihidro & bromotolueno (2 isômeros) & 2-furancarboxialdeido & 1-metoxi-4- \\
& 1,4-diclorobenzeno & 5-metil-2- & metilbenzeno \\
& & furancarboxialdeido & ácido decanoico \\
\end{tabular}

Fonte: MONARCA et al. (2004).

MONARCA et al. (2000) também verificaram a influência de desinfetantes alternativos ao cloro, tais como dióxido de cloro, ozônio, ácido peracético e radiação UV, na formação de compostos tóxicos e mutagênicos, em esgoto doméstico. As amostras de esgoto eram coletadas antes e após desinfecção, no verão e no inverno, e então adsorvidas em cartuchos de sílica $\mathrm{C}_{18}$. As amostras eram concentradas e testadas quanto à mutagenicidade com 
o teste Ames, e quanto à toxicidade empregando o teste de bioluminescência com a fotobactéria Vibrio fischeri. Para detectar dano ao DNA, foram realizados os teste de genotoxicidade - teste Allium e teste Tradescantia/ micronúcleo. Todos os desinfetantes produziram mutagenicidade, particularmente após tratamento com $\mathrm{ClO}_{2}$ e ozônio. O teste com Allium cepa apresentou resultado positivo apenas para as amostras tratadas com APA no inverno, e o teste com Tradescantia/MCN sempre apresentou resultado negativo. Desinfecção de esgoto bruto com $\mathrm{ClO}_{2}$ e APA acarretou em efeitos tóxicos, verificados por testes com bactérias marinhas.

A ozonização tornou-se particularmente atraente nas últimas décadas, para o tratamento da água, devido a exigências cada vez mais restritivas quanto aos níveis de qualidade da água de consumo. Nos EUA algumas ETAs implementaram a ozonização após o estabelecimento de diretrizes e regulamentos da EPA sobre a segurança da água em relação aos subprodutos da cloração. Em contrapartida, atualmente, vários estudos referentes aos subprodutos da ozonização são realizados.

Por ser um poderoso oxidante, o ozônio reage com os componentes orgânicos e inorgânicos presentes na água natural. Os principais subprodutos da ozonização identificados no tratamento de águas superficiais e subterrâneas são: aldeídos alifáticos de baixo peso molecular, em particular, formaldeído, acetaldeido, dialdeido glioxal, e ceto-aldeído-metil glioxal. Subprodutos da oxidação parcial, com funcionalidade carbonila, como, ácidos glioxílico, cetomalônico e pirúvico. Também são detectados, em estações que empregam ozônio, peróxido de hidrogênio e peróxidos orgânicos (no entanto, assim como os aldeídos, os mesmos podem ser removidos em filtros com biomassa ativa). Ainda, a ozonização da água natural contendo brometo decorre em um complexo ciclo de reações químicas, em que os produtos finais são brometo orgânico e bromato inorgânico (WEINBERG \& GLAZE, 1996).

Segundo LANGLAIS (1991), a complexidade da formação e do controle dos subprodutos da ozonização está relacionada a vários fatores, dentre eles: a extensa variação dos parâmetros que caracterizam a água natural, como a natureza da MON - que serve como material precursor para a formação dos 
subprodutos-, $\mathrm{pH}$, presença de radicais livre, além do próprio objetivo do tratamento, que estabelece as condições da ozonização. Ainda, a formação dos subprodutos da ozonização na água natural pode ocorrer por meio de ambos os mecanismos de reação do ozônio na água - tanto a oxidação direta dos compostos pelo ozônio molecular, quanto a oxidação dos compostos pelos radicais livres hidroxila, produzidos durante a decomposição do ozônio.

Assim, a diversidade e a concentração dos subprodutos da ozonização, que podem ser gerados numa ETA, variam consideravelmente de um sistema de tratamento de água para outro.

CHANG et al. (2002) empregaram pré-ozonização visando reduzir a formação de subprodutos da desinfecção. A água bruta usada no estudo era proveniente de um reservatório eutrofizado poluído por fertilizantes. Os resultados indicaram que a pré-ozonização reduziu de 9 a 54\% a concentração de carbono orgânico dissolvido, resultando em mais de 40\% a redução da formação dos subprodutos da desinfecção, especialmente o PFTHM. Os principais contribuintes para a formação dos subprodutos foram os ácidos húmicos e fúlvicos. Quando o ácido fúlvido foi pré-ozonizado, o aldeído resultante diminuiu. Baseado nos resultados de redução de COD, PFTHM e PFAOX a pré-ozonização foi considerada um método proficuo.

O ozônio reage com os componentes presentes na água bruta, como os ácidos húmicos, e forma numerosos subprodutos. No entanto, o padrão geral reportado pela maioria dos estudos é de que os subprodutos da ozonização parecem ser menos tóxicos do que os da cloração, que forma, dentre outros, clorohidroxifuranonas e THMs. Entretanto, a química do ozônio em solução aquosa, e seus efeitos sobre a saúde são muito complexos. As reações que ocorrem durante a ozonização são altamente dependentes da dose de $\mathrm{O}_{3}$ e do $\mathrm{pH}$. Isto explica as diferenças de resultados obtidos em experimentos sob variadas condições de operação. 


\subsection{4 - Processos combinados de desinfecção}

O uso combinado de duas ou mais substâncias ativas, sejam, agentes químicos, drogas, antibióticos, quimioterápicos, etc, é reconhecido por diversos setores, dentre eles o farmacêutico, visando melhorar a efetividade das substâncias químicas seja contra as doenças ou microrganismos causadores de doenças.

De acordo com LEHMANN (2001), a maioria dos agentes desinfetantes possui espectro de atividade muito diferenciado no que se refere à inativação dos diversos grupos de organismos existentes. Alguns atuam preferencialmente contra bactérias gram-positivas, outros, contra bactérias gram-negativas, enquanto que um terceiro grupo age melhor contra fungos, leveduras, etc. Ao invés de aumentar a concentração de um único agente desinfetante com a finalidade de expandir seu espectro de atividade, existe a opção de se adicionar um desinfetante secundário que possua atividade complementar, reduzindo-se a concentração dos agentes químicos aplicados.

O processo em que dois ou mais desinfetantes são usados seqüencialmente ou simultaneamente para produzir efeito sinergístico visando melhorar a efetividade da desinfecção é reconhecido pela USEPA (1999) como desinfecção interativa. Entretanto, a desinfecção combinada pode ser menos efetiva do que o processo individual; esse efeito depressivo é denominado antagonismo. Se a combinação dos desinfetantes não alterar a efetividade do processo, a interação é dita aditiva.

$\mathrm{Na}$ desinfecção de água de abastecimento, segundo USEPA (1999), os processos combinados são uma tendência promissora devido, principalmente, à crescente necessidade de produção de água de excelente qualidade tanto no que se refere à inativação de patogênicos quanto de minimização da formação de subprodutos da desinfecção.

Quanto à forma de aplicação dos desinfetantes, a desinfecção combinada pode ser: 
- seqüencial - os desinfetantes são aplicados um após o outro, em seqüência, como desinfetantes primário e secundário. Por exemplo, algumas ETAs empregam a alternativa de cloro livre, ozônio, dióxido de cloro, etc, como oxidantes primários seguidos por cloro livre ou monocloraminas para desinfecção final.

- simultânea - dois ou mais desinfetantes são aplicados simultaneamente em um tanque ou reator de mistura, objetivando a desinfecção primária. Compreende também os processos de mistura de oxidantes gerados no local.

BERENBAUM (1985) desenvolveu um método para testar o tipo de interação que pode ser obtida ao se empregar agentes químicos combinados. KOUAME \& HAAS (1991) adaptaram o modelo de BERENBAUM (1985), e propuseram um modelo matemático (Equação 1) para determinar a interação que pode ocorrer quando dois ou mais agentes desinfetantes são usados em combinação:

$$
\sum_{i=1}^{n} \frac{x_{i}}{y_{i}}=1
$$

$X_{i}$ : concentração do agente individual na combinação

$Y_{i}$ : concentração dos agentes que individualmente podem produzir o mesmo efeito do que quando combinados

i: agente individual

$\mathrm{n}$ : número total de agentes

A equação é interpretada da seguinte forma:

- no caso de interação sinergística a soma é menor do que 1

- no caso de interação antagônica a soma é maior do que 1

- no caso de aditividade a soma é igual a 1 (a interação é nula) 
Ocorre sinergismo quando a combinação dos desinfetantes providencia maior inativação microbiana do que a obtida somando-se os efeitos individuais de cada desinfetante separadamente. A magnitude do efeito sinergístico é igual à diferença entre a inativação alcançada pelos desinfetantes combinados e a soma das inativações alcançadas pelos desinfetantes individualmente (USEPA, 1999).

KOUAME \& HASS (1991) obtiveram efeito sinergístico na inativação de E. coli quando ambos, cloro livre e monocloramina, foram aplicados em um reator de mistura completa a $20^{\circ} \mathrm{C}$ e $\mathrm{pH}=8$. Os autores notaram que o efeito sinergístico aumentou com o aumento do tempo de residência e observaram que o dano subletal causado por um desinfetante proporcionou maior sensibilidade da E. coli ao segundo desinfetante. Observaram ainda que é de importância prática a coexistência de cloro livre e monocloramina em um único sistema e o respectivo aumento de efetividade que isso provoca. Assim, para dosagens relativamente mais baixas de produtos químicos, maiores inativações podem ser esperadas.

FINCH et al. (2000) estudaram diferentes alternativas de desinfecção combinada para verificar a inativação de microrganismos patogênicos de veiculação hídrica. Os autores observaram grande potencialidade dos processos combinados para o controle dos parasitas Giardia muris e Cryptosporidium parvum, embora não tenham observado nenhum efeito sinergístico sobre esporos aeróbios de Bacillus cereus. Tal fato foi atribuído a diferenças bioquímicas específicas dos esporos em relação aos parasitas encistados.

De maneira geral, os autores obtiveram os melhores resultados de inativação dos parasitas encistados com o ozônio como desinfetante primário. No entanto, especificamente para a inativação de Cryptosporidium, o impacto mais significativo foi obtido com a combinação ozônio / dióxido de cloro. A combinação ozônio / cloro livre foi tão efetiva quanto a combinação ozônio / monocloramina. Dióxido de cloro seguido por cloro livre também foi um processo bastante efetivo. E, cloro livre foi tão efetivo quanto monocloramina quando ambos eram usados como desinfetantes secundários. 
Em relação à inativação de Cryptosporidium, para todas as combinações dos desinfetantes empregados, a temperatura baixa e o $\mathrm{pH}$ elevado causaram efeito adverso sobre o sinergismo. No caso de inativação de Giardia observouse sinergismo em condições de temperatura baixa, porém, o pH elevado afetou negativamente a inativação. Os autores admitem que são necessários mais trabalhos para se avaliar os efeitos do $\mathrm{pH}$ e da temperatura ao se empregar processos combinados de desinfecção.

Além disso, muitas das particularidades referentes ao comportamento dos oxidantes químicos sobre os parasitas encistados estão relacionadas com os mecanismos de inativação. Pesquisas nessa área são importantes para a indústria da água de abastecimento, não apenas no que se refere aos processos combinados, mas também para os que empregam os desinfetantes isoladamente.

Na Tabela 3.7 encontram-se sumarizados alguns resultados observados por FINCH et al. (2000). 
Tabela 3.7- Efeitos sinergísticos observados com os processos combinados.

\begin{tabular}{|c|c|c|c|c|c|c|c|c|c|c|}
\hline \multirow{4}{*}{$\begin{array}{c}\text { Desinfetantes } \\
\text { cmbinados }\end{array}$} & \multicolumn{5}{|c|}{ Cryptosporidium } & \multicolumn{3}{|c|}{ Giardia } & \multicolumn{2}{|c|}{$\begin{array}{l}\text { Bacillus } \\
\text { cereus }\end{array}$} \\
\hline & \multicolumn{2}{|c|}{$5^{\circ} \mathrm{C}$} & \multicolumn{3}{|c|}{$22^{\circ} \mathrm{C}$} & \multicolumn{3}{|c|}{$5^{\circ} \mathrm{C}$} & \multicolumn{2}{|c|}{$22^{\circ} \mathrm{C}$} \\
\hline & \multicolumn{2}{|c|}{$\mathrm{pH}$} & \multicolumn{3}{|c|}{$\mathrm{pH}$} & \multicolumn{3}{|c|}{$\mathrm{pH}$} & \multicolumn{2}{|c|}{$\mathrm{pH}$} \\
\hline & 6 & 8 & 6 & 8 & 11 & 6 & 8 & 11 & 6 & 8 \\
\hline Ozônio-cloro livre & - & - & Sim & - & - & Sim & Sim & Não & Não & Não \\
\hline Ozônio-monocloramina & - & - & - & Sim & - & - & Sim & Sim & - & - \\
\hline Cloro livre-monocloramina & - & - & - & Sim & - & - & Sim & Não & - & - \\
\hline Dióxido de cloro-cloro livre & Não & Não & Sim & Sim & Não & Sim & $\operatorname{Sim}$ & - & - & Não \\
\hline Dióxido de cloro-monocloramina & Não & Não & $\operatorname{Sim}$ & $\operatorname{Sim}$ & Não & - & Não & Não & - & - \\
\hline Ozônio-dióxido de cloro & - & - & - & Sim & - & - & & - & - & - \\
\hline
\end{tabular}

Fonte: FINCH et al. (2000).

Nota do autor: (-) não realizado; "Sim" indica que foi observado sinergismo com a combinação dos desinfetantes e "Não" indica que não foi observado sinergismo com a combinação dos desinfetantes.

DRIEDGER et al. (2000) observaram sinergismo na inativação de $C$. parvum com a desinfecção seqüencial ozônio / cloro livre. A taxa de decaimento inicial dos esporos com a desinfecção combinada foi aproximadamente seis vezes e meio mais rápida quando comparada com o tratamento sem pré-ozonização, sob as mesmas condições. Em relação ao $\mathrm{pH}$, maior sinergismo foi observado para $\mathrm{pH}$ 6,0 do que $\mathrm{pH} 7,5$, e nenhum sinergismo foi observado para o $\mathrm{pH}$ 8,5. A taxa de inativação secundária com cloro livre diminuiu conforme aumentou o $\mathrm{pH}$.

VENCZEL et al. (1997) avaliaram o sistema de desinfecção alternativo que consistiu de uma mistura oxidante, produzida eletroquimicamente, denominada MIOX, para inativação de oocistos de C. parvum e esporos de $C$. perfringens. A eficácia da mistura dos oxidantes foi comparada com a do cloro livre. Os experimentos foram feitos em batelada em solução tampão - meio isento de componentes que exerciam demanda de oxidantes - em pH 7,0 e $25^{\circ} \mathrm{C}$. A solução MIOX foi consideravelmente mais efetiva do que o cloro livre na inativação de ambos microrganismos. Para a dose de $5 \mathrm{mg} / \mathrm{L}$ da mistura de 
oxidantes obteve-se inativação de $C$. parvum e $C$. perfringens maior do que 3 $\log _{10}(>99,9 \%)$ em $4 \mathrm{~h}$ de contato. Com o cloro livre nenhuma inativação de $C$. parvum foi observada desde 4 até $24 \mathrm{~h}$ de contato. No entanto, $1.4 \log _{10}$ de inativação de esporos de C. perfringens foi observado após 4 h de contato.

Um trabalho diferenciado foi realizado por BAEZA \& DUCOSTE (2004) que empregaram microesferas fluorescentes para simular a inativação de oocistos de C. parvum em um sistema de desinfecção que empregava processo combinado. O experimento foi realizado em batelada e incluiu ozônio como desinfetante primário e cloro livre como desinfetante secundário. Foi empregada técnica de citometria para verificar mudanças na distribuição da intensidade de fluorescência das microesferas, devido à exposição aos oxidantes. A "taxa de sobrevivência" $\left(\mathrm{N} / \mathrm{N}_{\circ}\right)$ das microesferas foi previamente calibrada, e selecionou-se uma intensidade limite de fluorescência para indicar a inativação dos oocistos de C. parvum. Ao se empregar os dois desinfetantes em seqüência foi desencadeado efeito sinergístico nas microesferas fluorescentes. A superfície do poliestireno das microesferas foi danificada devido à exposição ao ozônio e permitiu a difusão do cloro para o interior das microesferas, degradando uma camada de tintura existente no interior do polimero. A taxa de decaimento da intensidade de florescência das microesferas foi de 4 a 10 vezes mais rápida quando as microesferas eram expostas à desinfecção seqüencial. O experimento foi realizado, sob condições similares, com os dois desinfetantes isoladamente.

Os autores expõem que, a principal desvantagem do uso dessa técnica em escala real é o elevado custo das microesferas, mas recomendam seu uso em escala piloto, inclusive para validar modelos de caracterização e otimização dos processos de desinfecção em uma ETA.

\subsubsection{1 - Subprodutos associados aos processos combinados}

As concentrações e os tipos de subprodutos associados aos processos combinados de desinfecção dependem, entre outros fatores, dos desinfetantes primário e secundário empregados (no caso da desinfecção seqüencial), da 
mistura de oxidantes usada (aplicação simultânea) e da qualidade da água. Certamente, nenhum processo combinado é aplicável a todas as situações.

De acordo com USEPA (1999):

- A cloração da água bruta sem prévia remoção da matéria orgânica natural (MON), combinada com a cloração para manutenção de residual desinfetante, produz elevados níveis de subprodutos halogenados, enquanto que a pré-oxidação com ozônio ou dióxido de cloro pode reduzir a formação desses.

- O ozônio pode reduzir a formação de subprodutos halogenados em águas contendo baixas concentrações de brometo, entretanto, aumenta o conteúdo da matéria orgânica biodegradável (MOB) e pode levar ao crescimento bacteriano no sistema de distribuição. A remoção do carbono orgânico assimilável com filtração biológica reduz o potencial de crescimento bacteriano no sistema distribuidor.

- O uso de cloraminas como desinfetante secundário, em substituição ao cloro, reduz a formação de subprodutos clorados, entretanto, as cloraminas produzem seus próprios subprodutos, como o cloreto de cianogênio e o brometo de cianogênio.

- A opção pelo ozônio deve ser considerada cuidadosamente, porque ele produz aldeídos, aldocetoácidos, e ácidos carboxílicos, que, no entanto, podem ser removidos em filtros biológicos. A ozonização de águas contendo brometos leva à formação de subprodutos orgânicos brominados e bromato.

$\mathrm{Na}$ Tabela 3.8 estão sumarizadas algumas alternativas de processos combinados, bem como alguns dos subprodutos associados a cada uma destas opções. 
Tabela 3.8 - Subprodutos associados a alguns processos de oxidação/ desinfecção combinados.

\begin{tabular}{|c|c|c|c|c|}
\hline \multicolumn{3}{|c|}{ Alternativa } & \multirow[b]{2}{*}{$\begin{array}{c}\text { Subprodutos que } \\
\text { podem ser formados }\end{array}$} & \multirow[b]{2}{*}{ Comentário } \\
\hline Pré-oxidação & $\begin{array}{c}\text { Desinfecção } \\
\text { primária }\end{array}$ & $\begin{array}{l}\text { Desinfecção } \\
\text { secundária }\end{array}$ & & \\
\hline \multirow[t]{2}{*}{ Cloro } & \multirow[t]{2}{*}{ Cloro } & \multirow[t]{2}{*}{ Cloro } & $\mathrm{XSPDs}^{*}$ & $\begin{array}{l}\text { Máxima formação de } \\
\text { XSPDs comparado às } \\
\text { demais alternativas } \\
\text { propostas. Os principais } \\
\text { componentes são THMs e } \\
\text { AHAs. }\end{array}$ \\
\hline & & & Aldeídos & $\begin{array}{l}\text { Formados em } \\
\text { concentrações } \\
\text { relativamente baixas. }\end{array}$ \\
\hline \multirow[t]{2}{*}{ Cloro } & \multirow[t]{2}{*}{ Cloro } & \multirow[t]{2}{*}{ Cloramina } & $\begin{array}{l}\text { XSPDs } \\
\text { Cloreto de } \\
\text { cianogênio } \\
\text { Brometo de } \\
\text { cianogênio }\end{array}$ & $\begin{array}{l}\text { A formação de } \\
\text { pode ocorrer, } \\
\text { significantemente } \\
\text { reduzida em comparação } \\
\text { à alternativa cloro/ } \\
\text { cloro/ cloro. }\end{array}$ \\
\hline & & & Aldeídos & $\begin{array}{l}\text { Formados em } \\
\text { concentrações } \\
\text { relativamente baixas. }\end{array}$ \\
\hline \multirow{3}{*}{$\begin{array}{l}\text { Dióxido de } \\
\text { cloro }\end{array}$} & \multirow{3}{*}{ Dióxido de cloro } & \multirow{3}{*}{ Cloro } & XDBPs & $\begin{array}{l}\text { A formação de } \text { XDBPs } \\
\text { pode ser reduzida } \\
\text { dependendo do ponto de } \\
\text { aplicação do cloro }\end{array}$ \\
\hline & & & $\begin{array}{c}\text { Aldeídos, ácidos } \\
\text { carboxílicos, ácidos } \\
\text { maleicos }\end{array}$ & $\begin{array}{l}\text { Formados em } \\
\text { concentrações } \\
\text { relativamente baixas. }\end{array}$ \\
\hline & & & Clorito, clorato & $\begin{array}{l}\text { O clorito é o principal } \\
\text { subproduto do dióxido de } \\
\text { cloro. }\end{array}$ \\
\hline
\end{tabular}




\begin{tabular}{|c|c|c|c|c|}
\hline \multirow{3}{*}{$\begin{array}{l}\text { Dióxido de } \\
\text { cloro }\end{array}$} & \multirow{3}{*}{ Dióxido de cloro } & \multirow{3}{*}{ Cloramina } & XDBPs & $\begin{array}{l}\text { A formação de XDBPs } \\
\text { (especialmente THMs e } \\
\text { AHAs) é minimizada pela } \\
\text { supressão do uso do } \\
\text { cloro livre. }\end{array}$ \\
\hline & & & $\begin{array}{c}\text { Aldeídos, ácidos } \\
\text { carboxílicos, ácidos } \\
\text { maleicos }\end{array}$ & $\begin{array}{l}\text { Formados } \\
\text { concentrações } \\
\text { relativamente baixas. }\end{array}$ \\
\hline & & & Clorito, clorato & $\begin{array}{l}\text { O clorito é o principal } \\
\text { subproduto do dióxido de } \\
\text { cloro. }\end{array}$ \\
\hline \multirow{2}{*}{$\begin{array}{c}\text { Permanganato } \\
\text { de potássio }\end{array}$} & \multirow[t]{2}{*}{ Cloro } & \multirow[t]{2}{*}{ Cloro } & XDBPs & $\begin{array}{l}\text { A formação de } \text { XDBPs } \\
\text { pode ser reduzida } \\
\text { dependendo do ponto de } \\
\text { aplicação do cloro }\end{array}$ \\
\hline & & & Aldeídos & $\begin{array}{l}\text { Formados em } \\
\text { concentrações } \\
\text { relativamente baixas. }\end{array}$ \\
\hline \multirow[t]{2}{*}{$\begin{array}{c}\text { Permanganato } \\
\text { de potássio }\end{array}$} & \multirow[t]{2}{*}{ Cloro } & \multirow[t]{2}{*}{ Cloramina } & $\begin{array}{l}\text { XDBPs } \\
\text { Cloreto de } \\
\text { cianogênio } \\
\text { Brometo de } \\
\text { cianogênio }\end{array}$ & $\begin{array}{l}\text { A formação de XDBPs } \\
\text { pode ser reduzida em } \\
\text { comparação à alternativa } \\
\text { permanganato de } \\
\text { potássio/ cloro/ cloro. }\end{array}$ \\
\hline & & & Aldeídos & $\begin{array}{l}\text { Formados } \\
\text { concentrações } \\
\text { relativamente baixas. }\end{array}$ \\
\hline Ozônio & Ozônio & Cloro & XDBPs & $\begin{array}{l}\text { A formação de certos } \\
\text { XDBPs pode aumentar } \\
\text { ou diminuir comparado à } \\
\text { alternativa cloro/ cloro/ } \\
\text { cloro. Subprodutos } \\
\text { brominados podem ser } \\
\text { preocupantes } \\
\text { brometos se } \\
\text { presentes na água bruta. }\end{array}$ \\
\hline
\end{tabular}




\begin{tabular}{|c|c|c|c|c|}
\hline & & & $\begin{array}{l}\text { Bromato, aldeídos, } \\
\text { ácidos carboxílicos }\end{array}$ & $\begin{array}{l}\text { Embora formados em } \\
\text { concentrações } \\
\text { relativamente elevadas, } \\
\text { quantidade significativa } \\
\text { da matéria orgânica } \\
\text { biodegradável pode ser } \\
\text { removida em filtros } \\
\text { biológicos. }\end{array}$ \\
\hline & & & $\begin{array}{l}\text { XDBPs } \\
\text { Cloreto de } \\
\text { cianogênio } \\
\text { Brometo de } \\
\text { cianogênio }\end{array}$ & $\begin{array}{l}\text { A formação de } \text { XDBPs } \\
\text { (especialmente } \\
\text { minimizada } \\
\text { supressão do cloro livre. }\end{array}$ \\
\hline Ozônio & Ozônio & Cloramina & $\begin{array}{l}\text { Bromato, aldeídos, } \\
\text { ácidos carboxílicos }\end{array}$ & $\begin{array}{l}\text { Embora formados em } \\
\text { niveis } \\
\text { elevados, relativamente } \\
\text { significativa da matéria } \\
\text { orgânica biodegradável } \\
\text { pode ser removida em } \\
\text { filtros biológicos. }\end{array}$ \\
\hline Peroxônio & Cloro ou ozônio & Cloro & XSPDs & $\begin{array}{l}\text { A formação de certos } \\
\text { XSPDs pode aumentar ou } \\
\text { diminuir comparado à } \\
\text { alternativa cloro/ cloro/ } \\
\text { cloro. }\end{array}$ \\
\hline
\end{tabular}




\begin{tabular}{|c|c|c|c|c|}
\hline & & & $\begin{array}{l}\text { Bromato, aldeídos, } \\
\text { ácidos carboxílicos }\end{array}$ & $\begin{array}{l}\text { Embora formados em } \\
\text { concentrações } \\
\text { relativamente elevadas, } \\
\text { quantidade significativa } \\
\text { da matéria orgânica } \\
\text { biodegradável pode ser } \\
\text { removida em filtros } \\
\text { biológicos. Ainda a } \\
\text { formação de bromato } \\
\text { pode aumentar com o } \\
\text { peroxônio. }\end{array}$ \\
\hline & & & $\begin{array}{c}\text { XSPDs } \\
\text { Cloreto de } \\
\text { cianogênio } \\
\text { Brometo de } \\
\text { cianogênio }\end{array}$ & $\begin{array}{l}\text { A formação de XSPDs } \\
\text { pode diminuir comparado } \\
\text { à alternativa peroxônio/ } \\
\text { cloro/ cloro }\end{array}$ \\
\hline Peroxônio & Cloro ou ozônio & Cloramina & $\begin{array}{l}\text { Bromato, aldeídos, } \\
\text { ácidos carboxílicos }\end{array}$ & $\begin{array}{l}\text { Embora formados em } \\
\text { concentrações } \\
\text { relativamente elevadas, } \\
\text { quantidade significativa } \\
\text { da matéria orgânica } \\
\text { biodegradável pode ser } \\
\text { removida em filtros } \\
\text { biológicos. Ainda, a } \\
\text { formação de bromato } \\
\text { pode aumentar com o } \\
\text { peroxônio. }\end{array}$ \\
\hline \multirow[t]{2}{*}{ Cloro } & \multirow[t]{2}{*}{ UV } & \multirow[t]{2}{*}{ Cloramina } & $\begin{array}{c}\text { XSPDs } \\
\text { Cloreto de } \\
\text { cianogênio } \\
\text { Brometo de } \\
\text { cianogênio }\end{array}$ & $\begin{array}{l}\text { Pode formar XSPDs } \\
\text { devido à pré-oxidação. }\end{array}$ \\
\hline & & & Aldeídos & Concentrações baixas \\
\hline
\end{tabular}




\begin{tabular}{|c|c|c|c|c|}
\hline \multirow{2}{*}{$\begin{array}{c}\text { Permanganato } \\
\text { de potássio }\end{array}$} & \multirow[t]{2}{*}{ UV } & \multirow[t]{2}{*}{ Cloramina } & XSPDs & $\begin{array}{lr}\text { Concentrações } & \text { muito } \\
\text { baixas devido } & \text { aos } \\
\text { oxidantes } & \text { menos } \\
\text { reativos. } & \end{array}$ \\
\hline & & & $\begin{array}{c}\text { Aldeídos, ácidos } \\
\text { carboxílicos }\end{array}$ & $\begin{array}{l}\text { Concentrações muito } \\
\text { baixas devido aos } \\
\text { oxidantes menos reativos }\end{array}$ \\
\hline
\end{tabular}

"XSPDs - subprodutos halogenados da desinfecção.

Fonte: USEPA (1999).

Também, subprodutos não identificados até o presente podem ocorrer dependendo da combinação de oxidantes empregada. DIETRICH \& HOEHN (1991) apud OXENFORD (1996) apresentaram que o dióxido de cloro seguido por cloro livre levou à detecção de odor de "urina de gato" na torneira das casas de consumidores; para alguns o odor foi comparável à "querosene". Os autores acreditam que o cloro reagiu com o clorito para produzir dióxido de cloro livre no sistema de distribuição. O dióxido de cloro, por sua vez, reagiu com substâncias presentes no ar das tubulações do sistema de distribuição causando o odor.

TENG \& VEENSTRA (1996) estudaram o potencial de formação de subprodutos de quatro processos de desinfecção: cloro livre, cloramina, préozonização/ cloro livre e pré-ozonização/ cloramina. O estudo enfocou a influência das características dos precursores no potencial formador dos subprodutos. Os autores obtiveram que os processos de cloraminação e préozonização/ cloramina controlaram a formação de THM. O menor PFTHM foi alcançado com a pré-ozonização/ cloramina. No processo de cloraminação, ocorreu maior produção de ácido tricloroacético (ATCA) e ácido dicloroacético (ADCA) em geral, para a faixa de massa molecular entre 10.000 a 100 . 


\section{4 - MATERIAL E MÉTODOS}

\section{1 - Considerações iniciais}

O trabalho experimental consistiu de ensaios de desinfecção em escala de laboratório em batelada, em que se empregou os desinfetantes cloro, ácido peracético, ozônio e o processo combinado ozônio / cloro para águas de estudo com cor baixa e cor elevada com o objetivo de avaliar e comparar a ação dos desinfetantes na inativação dos microrganismos indicadores $E$. coli, colifagos e C. perfringens. Ainda, avaliar a ação dos referidos desinfetantes sobre a matéria orgânica presente na água de estudo e a formação de THM nos processos em que se empregou cloro.

As concentrações dos desinfetantes e os tempos de contato usados foram escolhidos baseado em ensaios-testes mediante valores que não acarretassem na inativação total dos microrganismos indicadores empregados. Todos os ensaios de desinfecção foram realizados em duplicata.

\section{2 - Água de estudo}

Devido à natureza comparativa dos experimentos desejava-se obter reprodutibilidade da água de estudo para os diferentes processos de desinfecção empregados. Assim, a água foi preparada no Laboratório Avançado de Tratamento e Reúso de Águas (LATAR) sob condições estritamente controladas. Usou-se água do poço artesiano que abastece o campus da EESCUSP. Os parâmetros temperatura, pH, alcalinidade e turbidez da água do poço não foram modificados. A água proveniente do poço passava por um reator de radiação ultravioleta, para eliminação de microrganismos que porventura estivessem presentes na água, como coliformes totais que foram detectados em exames prévios realizados na água do poço antes dos ensaios de desinfecção.

O reator de radiação UV da marca GERMETEC, modelo GPJ-36-1, consistia de uma câmara cilindrica de aço inoxidável (1000 x 290 x 150 mm), possuindo em seu interior uma lâmpada da marca GERMILAMP de arco 
voltaico de vapor de mercúrio de baixa pressão, protegida por um bujão de quartzo. A água entrava pela conexão inferior do reator, circulava pelo aparelho e saía pela conexão superior do mesmo. A seguir, a água era coletada em um recipiente de plástico, com capacidade de 20L para subseqüente mistura com os componentes que eram adicionados à água.

A agitação vigorosa da água era feita por cerca de 30 minutos, por meio de equipamento mecânico constituído de estator em forma de placa soldada na extremidade do eixo de aço inoxidável, o qual era acionado por motor elétrico com dispositivo que permitia a variação da rotação. A agitação da água era essencial para a mistura completa dos microrganismos adicionados. $\mathrm{O}$ aparato empregado para preparação da água, o reator UV e o equipamento de agitação são apresentados na Figura 4.1, e na Figura 4.2 o equipamento de radiação UV, em detalhe.

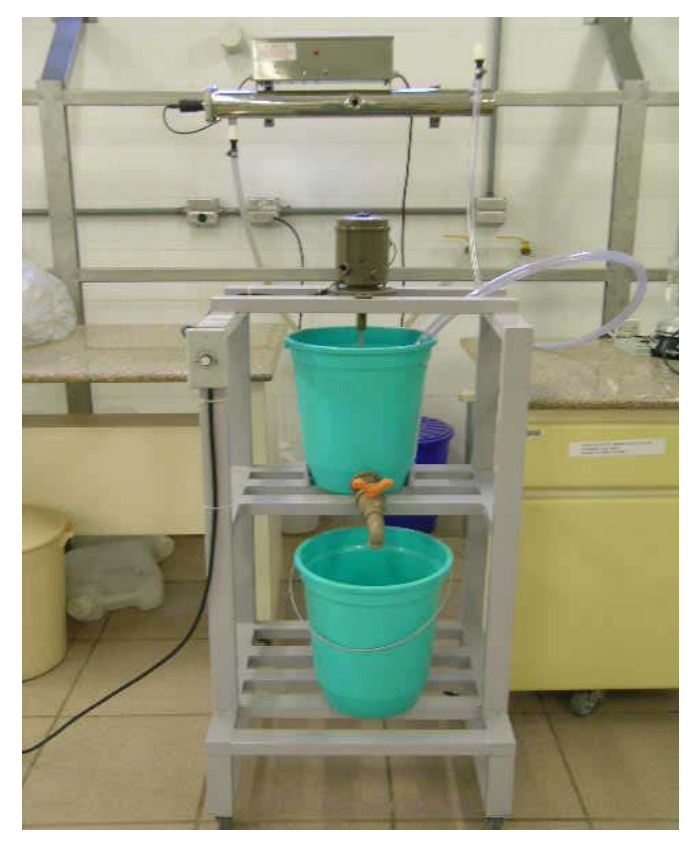

Figura 4.1- Foto do equipamento de agitação da água.

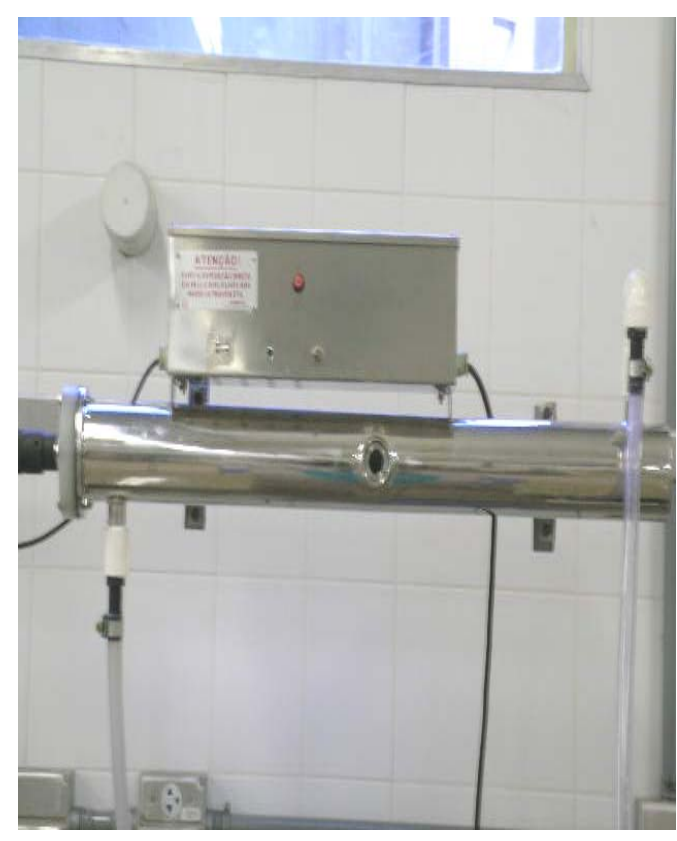

Figura 4.2 - Foto do aparelho de radiação UV. 
Foram estudadas águas com características de cor baixa (menor que $5 \mathrm{uH}$ ) e cor elevada (maior que $100 \mathrm{uH}$ ). Para obtenção de cor, adicionava-se à água substância húmica extraída de solo turfoso preparada por BENINI (2003) em cujo trabalho está descrita a metodologia usada para a extração da substância húmica bem como sua caracterização.

Os microrganismos indicadores usados na pesquisa eram cultivados

com antecedência e adicionados à água de estudo no momento do experimento.

\section{3 - Cultivo, preservação e quantificação dos microrganismos indicadores}

Os microrganismos indicadores empregados nesse trabalho foram $E$. coli (indicadora de bactérias), colifagos (indicadores de vírus) e C. perfringens (indicadora de protozoários). As cepas de bactérias usadas foram E. coli ATCC 11229, C. perfringens ATCC 13124 e E. coli CIP 55.30 como hospedeira dos fagos, todas adquiridas da Fundação Tropical de Pesquisa e Tecnologia "André Tosello" situada em Campinas, SP. As cepas eram recebidas reativadas em ágar nutriente inclinado em duplicata. Os colifagos foram isolados de esgoto sanitário proveniente do reator anaeróbio de leito expandido (RALEX) situado no campus da EESC-USP.

A preservação de uma coleção de culturas para pronta disponibilidade é uma tarefa dificil. O método das freqüentes transferências em meios de cultura adequados, como mais comumente feito, requer não só grande gasto de tempo e material, como também envolve a possivel perda das características biológicas e culturais dos organismos. Isso sem mencionar as perdas que ocorrem por contaminação e secagem do substrato (PELCZAR, 1996).

Existem vários métodos para manter as culturas e, ao mesmo tempo, preservá-las o mais próximo possivel de seu estado original com a finalidade de prevenir perdas de valiosas propriedades bioquímicas. O método empregado na pesquisa foi o da preservação da cultura em substrato-ágar e subseqüente transferência de inóculos para tubos de ensaio contendo meios de cultura especificos, sendo essas transferências feitas periodicamente para meios de 
fabricação recente. No entanto, microrganismos conservados dessa maneira apresentam consideráveis variações em morfologia e comportamento, assim, a fim de minimizar tais efeitos e para evitar o surgimento de células mais resistentes, a cada 3 meses novos colifagos eram isolados de esgoto sanitário e novas culturas de bactérias, reativadas em slants, eram solicitadas da Fundação Tropical de Pesquisas e Tecnologia André Tosello.

\subsection{1 - Escherichia coli}

Algumas características referentes à cepa de E.coli ATCC 11229 estão apresentadas na Tabela 4.1 .

Tabela 4.1 - Informações referentes à bactéria E. coli ATCC 11229 .

\begin{tabular}{|c|c|}
\hline Espécie & Escherichia coli \\
\hline Coleção & ATCC 11229 \\
\hline Grupo & Gram-negativa, Entérica \\
\hline Metabolismo & anaeróbia facultativa \\
\hline Morfologia & Bacilos \\
\hline Tamanho $(\mu \mathrm{m})$ & 0,4 a 1,5 por 1,0 a 6,9 \\
\hline Habitat & intestino humano e de animais de sangue quente \\
\hline Patogenicidade & $\begin{array}{l}\text { na maioria dos casos inócua, podendo eventualmente } \\
\text { ocorrer diarréia e infecções no trato digestivo e urinário, } \\
\text { bem como no sistema nervoso central }\end{array}$ \\
\hline
\end{tabular}

Fonte: SHANG23 et al., 1996; HALABY24, 1998 apud SHANG \& BLATCHLEY (2000).

O meio de cultura usado para crescimento e manutenção da cepa de E.coli ATCC 11229 foi o Tryptic Soy Broth (TSB), Difco 0370-17. A composição do meio TSB está apresentada na Tabela 4.2.

${ }^{23}$ SHANG et al (1996). Evaluation of DBNPA/ chlorine for municipal wastewater disinfection. Final Project Report submitted to Dow Chemical (Midland, MI) by School of Civil Engineering, Purdue University, West Lafayette, IN.

${ }^{24}$ HALABY, T.N. (1998). Bacterial responses to physical disinfectants. Mater's Thesis, Purdue University, west Lafayette, IN. 
Tabela 4.2 - Composição do meio TSB.

\begin{tabular}{|c|c|}
\hline $\begin{array}{c}\text { Bacto tryptone } \\
\text { (digestão pancreática de } \\
\text { caseina) }\end{array}$ & $17,0 \mathrm{~g}$ \\
\hline $\begin{array}{c}\text { Bacto soytone } \\
\text { (digestão papaíca de soja) }\end{array}$ & $3,0 \mathrm{~g}$ \\
\hline Bacto dextrose & $2,5 \mathrm{~g}$ \\
\hline Cloreto de sódio & $5,0 \mathrm{~g}$ \\
\hline Fosfato dipotássico & $2,5 \mathrm{~g}$ \\
\hline
\end{tabular}

Dissolveram-se $30 \mathrm{~g}$ de TSB em um litro de água destilada aquecendo-se até dissolução completa dos componentes, sem, entretanto, deixar atingir temperatura de ebulição. O mesmo era esterilizado em autoclave a $121^{\circ} \mathrm{C}$ e $103,3 \mathrm{kPa}$ por 15 minutos, o $\mathrm{pH}$ final foi em torno de 7,3 a $25^{\circ} \mathrm{C}$.

A repicagem da cepa de E.coli ATCC 11229 foi realizada com o auxílio de uma alça de platina em que se transferia pequena porção do inóculo original para $10 \mathrm{~mL}$ de TSB. Incubava-se a $36 \pm 1^{\circ} \mathrm{C}$ por $24 \pm 1 \mathrm{~h}$. No dia seguinte, transferia-se o pré-inóculo para $90 \mathrm{~mL}$ de meio TSB contendo $10 \%$ de glicerol (o glicerol era adicionado com a finalidade de não danificar as células que seriam posteriormente congeladas). Após $1 \frac{1}{2}$ hora em estufa a $36 \pm 1^{\circ} \mathrm{C}$, homogenizava-se e distribuia-se a suspensão bacteriana em flaconetes estéreis tipo eppendorfs e armazenava-se em congelador a $-4^{\circ} \mathrm{C}$.

A concentração bacteriana em cada eppendorf era verificada na ocasião dos ensaios.

\subsubsection{1 - Quantificação de E. coli}

Para quantificação de E.coli foi utilizada a técnica de filtração em membranas, usando o meio Chromocult ${ }^{\circledR}$ Coliform Agar (Merck Cat.No.1.10426) que determina simultaneamente a presença de coliformes totais e E.coli. Para o teste, um volume de $100 \mathrm{~mL}$ de amostra era filtrado em membrana estéril de porosidade 0,45 $\mu \mathrm{m}$, marca Gelman GN-6. Após a 
filtração as membranas contendo as células bacterianas eram colocadas em placas de Petri contendo o referido meio e incubadas a $36 \pm 1^{\circ} \mathrm{C}$ por $24 \pm 1 \mathrm{~h}$. Nesta técnica as colônias que apresentaram coloração salmão / vermelha eram reconhecidas como coliformes totais (sem E. coli) e coloração azul-escura / violeta como E. coli.

$\mathrm{Na}$ figura 4.3 estão representadas colônias de coliformes totais e E. coli em placa de Petri.

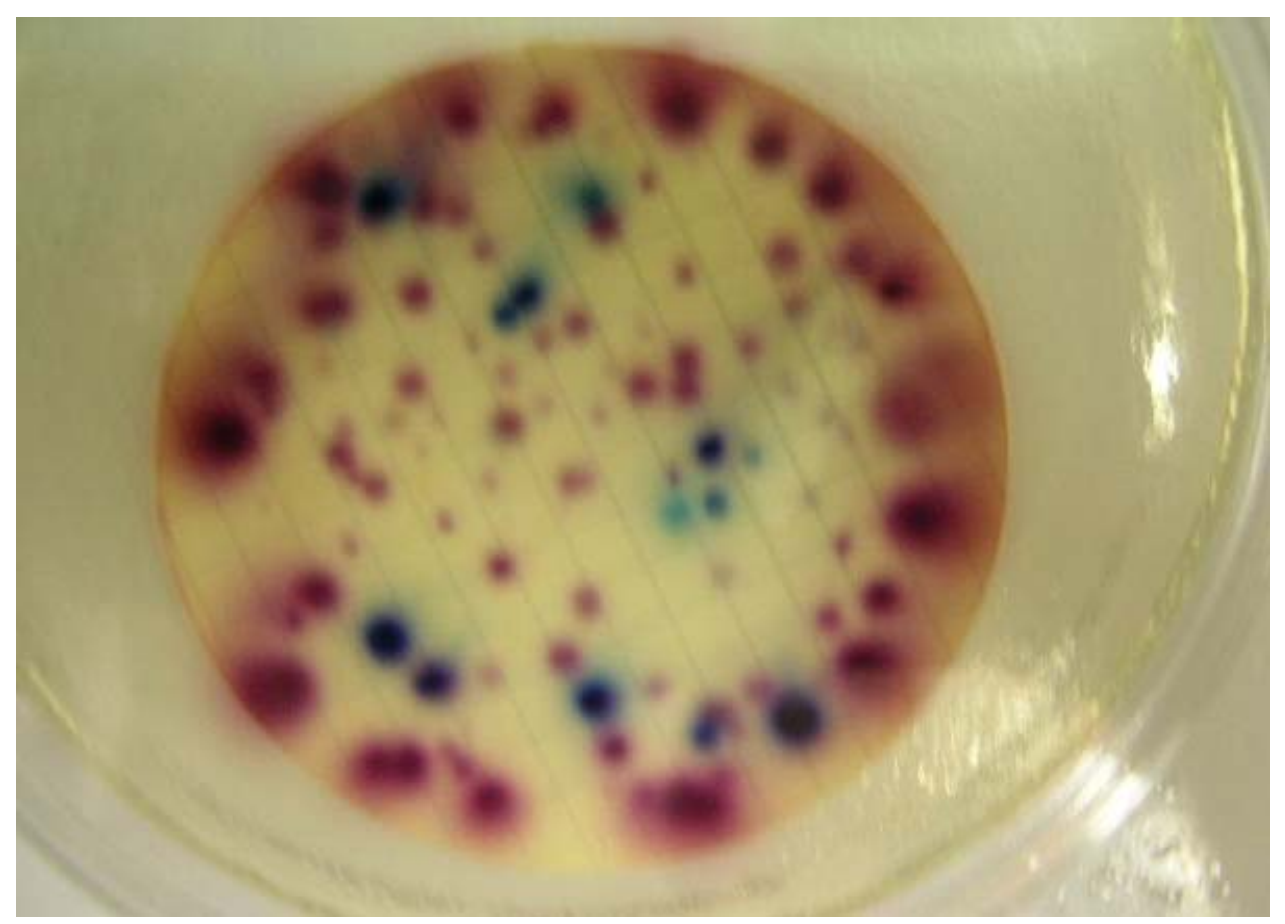

Figura 4.3 - Colônias de coliformes totais e E. coli em placa de Petri.

Conforme EPA (2002) a técnica de filtração em membranas usando Chromocult ${ }^{\circledR}$ coliform Agar é baseada na detecção de três enzimas: $\beta$ galactosidase, a qual é específica do grupo coliforme total, $\beta$-glucuronidase e triptofanase, ambas características de E. coli. Para detecção de $\beta$-galactosidase, o meio contém o substrato enzimático cromogênico 6-cloro-3-indolil-3- $\beta$-Dgalactopiranoside (SALMON-GAL). Sob hidrólise por $\beta$-D galactosidase, SALMON-GAL libera o composto cloroindigo que indica as colônias de coloração salmão / vermelha. Para a detecção de $\beta$-glucuronidase, o meio contém outro substrato enzimático cromogênico, 5-bromo-4-cloro-3-indoxil- $\beta$ - 
D-glucuronic ácido, sal cyclohexylammonium (X-GLUC). Sob hidrólise por $\beta$ glucuronidase, X-GLUC libera o composto cromogênico bromocloroindigo que indica as colônias de coloração azul-clara / turquesa. A E.coli produz ambos $\beta$ galactosidase e $\beta$-glucuronidase que age em ambos SALMON-GAL e X-GLUC respectivamente. A hidrólise simultânea desses substratos cromogênicos forma colônias de coloração azul-escura / violeta, que são facilmente distinguíveis de outros coliformes.

\subsection{2 - Colifagos}

Os colifagos empregados como indicadores de vírus nessa pesquisa foram isolados de esgoto sanitário.

$\mathrm{O}$ isolamento dos fagos era realizado a partir de diluições seriadas da amostra de esgoto até aproximadamente 10-4. A seguir, em tubos de ensaio contendo 5,5 mL de TSA modificado adicionava-se $5 \mathrm{~mL}$ da diluição escolhida, mais $1 \mathrm{~mL}$ da cepa de E.coli CIP 55.30, hospedeira apropriada para os fagos. Incubava-se em estufa a $36 \pm 1^{\circ} \mathrm{C}$ por 6 horas. Com auxílio de uma alça de platina removia-se as placas de lise e colocava-as em tubos de ensaio contendo o meio TSB, incubando a seguir por 24 horas. No dia seguinte, centrifugava-se a $3000 \mathrm{rpm}$ e depois filtrava-se (no sobrenadante é que ficam os fagos). Os tubos de ensaio contendo os fagos isolados eram guardados em geladeira a $4{ }^{\circ} \mathrm{C}$ por períodos de aproximadamente 2 meses. Ao final desse tempo descartava-se o material estoque porventura remanescente e procedia-se novo isolamento dos fagos.

Os meios usados para isolamento e quantificcação dos fagos foram o TSB (Tabela 4.2) e o TSA (Tryptic Soy Agar) modificado, cuja composição está apresentada na Tabela 4.3. 
Tabela 4.3 - Composição do meio TSA modificado.

\begin{tabular}{|l|l|}
\hline TSA (Difco 236950) & $40 \mathrm{~g}$ \\
\hline Nitrato de amônia - $\mathrm{NH}_{4} \mathrm{NO}_{3}$ p.a. & $1,6 \mathrm{~g}$ \\
\hline Nitrato de estrôncio - $\mathrm{Sr}\left(\mathrm{NO}_{3}\right)_{2}$ & $0,21 \mathrm{~g}$ \\
\hline
\end{tabular}

Os componentes apresentados na Tabela 4.3 eram adicionados em 1,0 L de água destilada e levados ao aquecimento até completa dissolução, sem atingir a temperatura de ebulição. Distribuia-se volumes de 5,5 mL do meio em tubos de ensaio, autoclavando a seguir a $121^{\circ} \mathrm{C}$ por 15 minutos. $\mathrm{O} \mathrm{pH}$ final do meio ficou em torno de 7,3 .

\subsubsection{1 - Quantificação dos colifagos}

O método de ensaio viral empregado foi o ensaio de placa. Segundo esse método são realizadas diluições seriadas da amostra a ser examinada e uma alíquota de cada diluição é inoculada em uma placa contendo uma camada bacteriana susceptivel. Ocorre a infecção e novos fagos são produzidos a partir de cada célula de bactéria infectada, lisando a célula. Estes fagos, então, infectam as células susceptiveis vizinhas e as lisam. Após a incubação e alguns ciclos de lise, tornam-se visiveis sobre a camada bacteriana áreas claras, chamadas placas (Figura 4.4). 


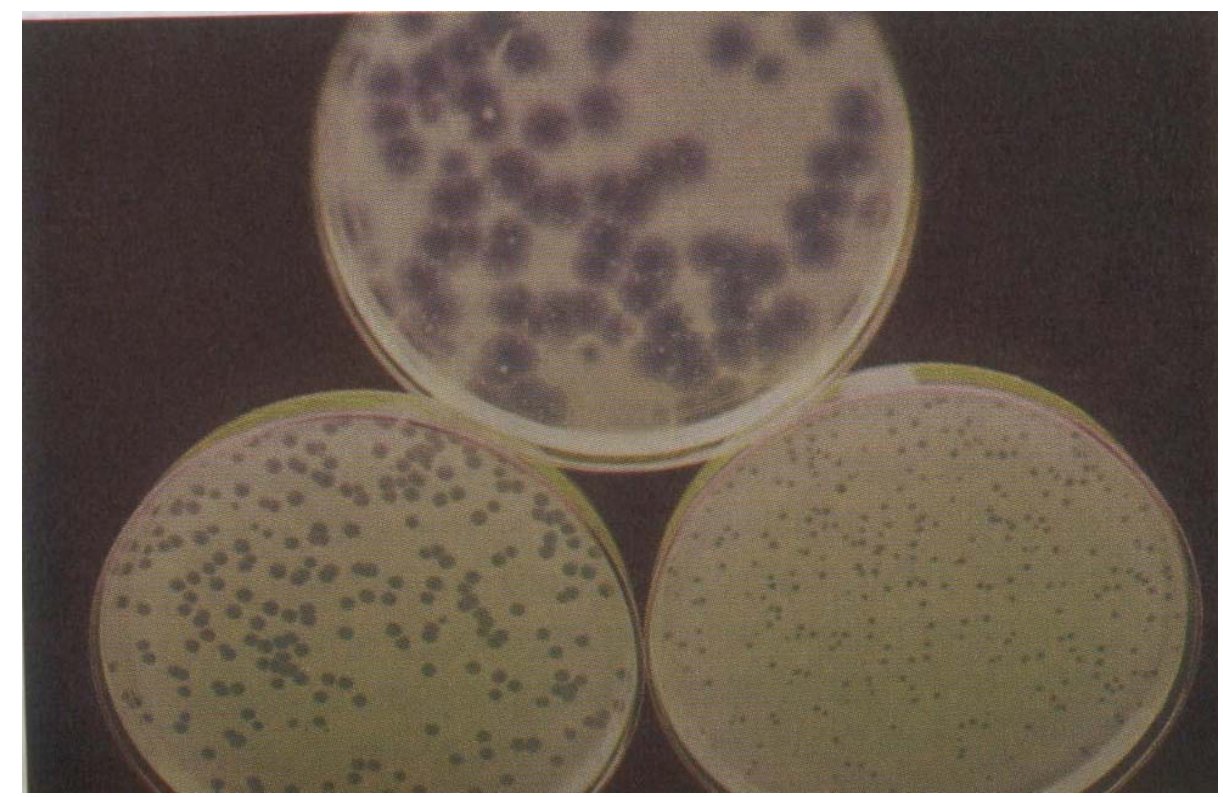

Figura 4.4 - Placas inoculadas com diferentes tipos de colifagos. A placa superior com o fago lambda, a placa do lado esquerdo inferior com o fago T4, a placa direita com fago T2. Fonte: BLACK (1999).

Cada placa representa um fago infectivo. Assim, através da contagem do número de placas e da multiplicação deste número pelo fator de diluição, estima-se o número de fagos na amostra. Algumas vezes, dois ou mais fagos ficam dispostos muito perto um do outro e formam uma única placa, por outro lado, nem todos os fagos são infectivos. Assim, a contagem do número de placas se aproxima, mas não é necessariamente igual ao número de fagos infectivos na suspensão. Por essa razão essas contagens são referidas como unidades formadoras de placas (UFP) e não como número de fagos (BLACK, 1999).

A metodologia seguida para o ensaio de placa foi a Norma CETESB L5.225, cujo procedimento compreendeu as etapas:

- quatro tubos de ensaio com TSA modificado foram fundidos em banhomaria a $44,5^{\circ} \mathrm{C}$;

- descongelou-se os frascos contendo a bactéria hospedeira em banhomaria a $44,5^{\circ} \mathrm{C}$ por 5 minutos; 
- levou-se a amostra a ser examinada ao banho-maria $\left(44,5^{\circ} \mathrm{C}\right)$ por 5 minutos, sendo realizadas diluições para as amostras em que se esperava mais de 1000 colifagos/100 mL;

- para cada um dos quatro tubos com TSA modificado transferiu-se $5 \mathrm{~mL}$ da amostra ou de sua diluição e $1 \mathrm{~mL}$ da suspensão da bactéria hospedeira E. coli CIP 55.30;

- os tubos de ensaio eram homogeneizados, e seus conteúdos vertidos em placas de Petri;

- as placas eram homogeneizadas em movimentos circulares em forma de oito e incubadas em estufa a $36^{\circ} \mathrm{C}$ durante 4 a 6 horas.

Após 4 ou 6 horas em estufa a $36^{\circ} \mathrm{C}$ as placas foram retiradas para contagem. A contagem pode ser auxiliada por um contador de colônias. Vale ressaltar que todo o trabalho foi feito sob assepsia.

O número de colifagos é obtido pela somatória da contagem das placas de lise nas 4 placas de Petri utilizadas por amostra. O resultado é expresso como número de unidades formadoras de placa (UFP/100 mL).

\subsection{3 - C. perfringens}

A cepa de C. perfringens ATCC 13124 foi adquirida da Fundação Tropical de Pesquisas e Tecnologia "André Tosello" e recebida reativada em slants AS (Agar sangue) em duplicata. Algumas informações referentes à cepa de C. perfringens ATCC 13124 são apresentadas na Tabela 4.4. 
Tabela 4.4 - Informações referentes à bactéria C. perfringens ATCC 13124.

\begin{tabular}{|l|l|}
\hline Espécie & Clostridium perfringens \\
\hline Coleção & ATCC 13124 \\
\hline Grupo & Gram-positivo \\
\hline Metabolismo & Anaeróbio obrigatório \\
\hline Morfologia & Bacilos curtos \\
\hline Tamanho $(\mu \mathrm{m})$ & 0,6 a 2,4 por 1,3 a 19,0 \\
\hline Habitat & $\begin{array}{l}\text { largamente distribuído no meio ambiente, no solo, habitante do } \\
\text { trato intestinal de pessoas saudáveis e animais (gado, porcos, } \\
\text { aves e peixes). }\end{array}$ \\
\hline Patogenicidade & $\begin{array}{l}\text { Pode causar intoxicação alimentar quando ingeridas em grande } \\
\text { quantidade, devido a enterotoxina, formada durante o processo } \\
\text { de esporulação dentro do intestino, além de infecção em vários } \\
\text { órgãos e tecidos como gangrena gasosa, infecções intra- } \\
\text { abdominais, cutâneas e do tecido sub-cutâneo. }\end{array}$ \\
\hline
\end{tabular}

Fonte: Adaptado da Norma CETESB L5.213 e Manual das Doenças Transmitidas por Alimentos (2002).

O inóculo original era repicado em meio de cultura denominado DRCM, meio diferencial enriquecido para clostrídios e incubado em estufa a $36 \pm 1{ }^{\circ} \mathrm{C}$, em jarra de anaerobiose (sistema GasPak), por 48 h. A composição do meio DRCM está apresenta na Tabela 4.5.

Tabela 4.5 - Composição do meio DRCM

\begin{tabular}{|l|l|}
\hline COMPONENTE & QUANTIDADE \\
\hline Peptona & $10,0 \mathrm{~g}$ \\
\hline Extrato de carne purificado (em pó) & $10,0 \mathrm{~g}$ \\
\hline Acetato de sódio hidratado & $5,0 \mathrm{~g}$ \\
\hline Extrato de levedura & $1,5 \mathrm{~g}$ \\
\hline Amido solúvel & $1,0 \mathrm{~g}$ \\
\hline Glicose & $1,0 \mathrm{~g}$ \\
\hline L-cisteína & 0,5 \\
\hline Água destilada & $1000 \mathrm{~mL}$ \\
\hline
\end{tabular}


A jarra de anaerobiose empregada para o cultivo de $C$. perfringens faz parte do denominado sistema anaeróbio GasPak ${ }^{\mathrm{TM}}$. Na Figura 4.5 é apresentada a foto da jarra de anaerobiose empregada, em seu interior um tubo de ensaio com cultura de C. perfringes pronta para uso.

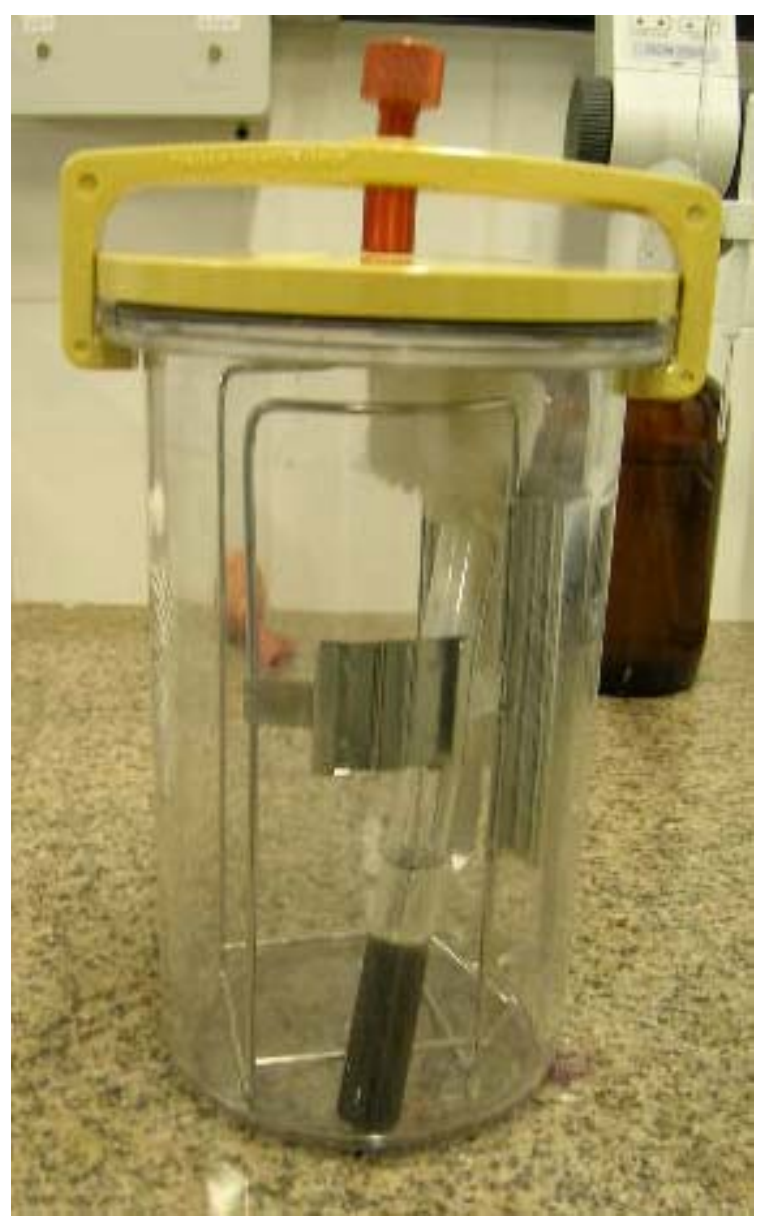

Figura 4.5 - Jarra de anaerobiose usada para cultivo de C. perfringens. No interior da jarra, tubo de ensaio com cultura de $C$. perfringens.

Os dois componentes básicos do sistema anaeróbio GasPak ${ }^{\mathrm{TM}}$ são o envelope gerador de hidrogênio e dióxido de carbono, além de um catalisador de paládio em temperatura ambiente. Adiciona-se água ao envelope GasPak ${ }^{\mathrm{TM}}$ produzindo-se hidrogênio. O hidrogênio reage com o oxigênio na superficie do catalisador para formar água e, conseqüentemente, uma condição de anaerobiose. Também é componente do sistema GasPak ${ }^{\mathrm{TM}}$ uma tira de 
indicador de anaerobiose (solução de azul de metileno) que muda de azul para incolor na ausência de oxigênio, denotando a anaerobiose.

\subsubsection{1 - Quantificação de C. perfringens}

Para quantificação de C. perfringens, foi usada técnica de tubos múltiplos em que se determinou o número mais provável (NMP) de microrganismos. Conforme essa técnica, duas etapas, denominadas respectivamente de presuntiva e confirmativa são necessárias para obtenção do resultado final. $\mathrm{Na}$ etapa presuntiva as bactérias pesquisadas reduzem o sulfito adicionado (solução de citrato férrico a 7\% e solução de sulfito de sódio a 4\%) ao meio de cultura DRCM, formando sulfeto e provocando o enegrecimento ou a turvação do meio. Os tubos em série de 5 inoculados com volumes de 1,0 $\mathrm{mL}$ das amostras de água eram incubados em anaerobiose a $36 \pm 1^{\circ} \mathrm{C}$ por 48 horas.

A etapa confirmativa consistia na transferência de cada cultura dos tubos de DRCM com resposta positiva para um tubo contendo meio de cultura denominado "Litmus milk" (leite desnatado e tornassol), os tubos eram incubados em anaerobiose a $36 \pm 1^{\circ} \mathrm{C}$ por 48 horas. Os clostrídios sulfitoredutores fermentam o leite provocando a coagulação do caseinogênio. Durante o processo, a lactose é fermentada com produção de ácido e grande quantidade de gás, o que provoca o rompimento dos coágulos. A produção de ácido era evidenciada pela coloração rosa do indicador de $\mathrm{pH}$, o tornassol.

Para obtenção de ambiente anaeróbio nas etapas presuntiva e confirmativa era adicionado a cada tubo de ensaio ao final da inoculação, vaselina liquida em volume suficiente para formar camada com aproximadamente $2 \mathrm{~cm}$ de espessura.

A metodologia para quantificação de C. perfringens seguiu a Norma CETESB/L5.213 (1993). 


\section{4 - Separação das células dos microrganismos dos meios de cultura}

Realizou-se um ensaio - teste de desinfecção com cloro, em que a água de estudo estava isenta dos meios de cultura usados para crescimento e manutenção das cepas de microrganismos empregados, com o objetivo de diminuir a demanda pelos oxidantes, especialmente do cloro, provocada pela matéria orgânica inerente a esses meios de cultura.

O procedimento para separação das células dos microrganismos de seus respectivos meios de cultura compreendeu as etapas de centrifugação das culturas de microrganismos em meio líquido a 300 x G, a retirada do sobrenadante com assepsia e homogeneização do pellet com solução salina de cloreto de sódio 0,9\%. Em seguida, repetia-se a operação centrifugando-se novamente, até que o sobrenadante ficasse completamente claro. Após mais ou menos três "lavagens" o pellet ficava como uma solução muito diluída de leite.

\section{5 - Desinfecção com cloro}

Os ensaios de desinfecção com cloro foram realizados em instalação de batelada, empregando béqueres de vidro de borossilicato de $2 \mathrm{~L}$ de capacidade, sobre agitadores magnéticos.

Foi empregado hipoclorito de sódio $(\mathrm{NaOCl})$, que foi diluído em água destilada estéril para obtenção de solução de $1000 \mathrm{mg} / \mathrm{L}$. Vale ressaltar que essa água não exerceu demanda de cloro, o que foi verificado pelo método utilizado para a medição de cloro residual, o DPD colorimétrico.

Os ensaios foram realizados em quatro béqueres de vidro, dispostos sobre agitadores magnéticos. A água de estudo previamente preparada era distribuída em volumes de 1,0 L em cada béquer. Adicionavam-se volumes da solução de hipoclorito de sódio (1000 mg/L) de forma a se obter as dosagens de: 2,$0 ; 3,0 ; 4,0$ e 5,0 mg/L de cloro aplicado. Os tempos de contato de 5; 10; 15 e 20 minutos eram cronometrados a partir do momento da aplicação do

cloro na água. Imediatamente após cada tempo de contato, um volume de aproximadamente $10 \mathrm{~mL}$ era retirado da amostra para medição do cloro 
residual e ao restante da amostra no béquer contendo cloro era adicionado tiossulfato de sódio $(3 \%)$ na proporção de $0,1 \mathrm{~mL}$ para cada $100 \mathrm{~mL}$ de amostra (STANDARD METHODS FOR THE EXAMINATION OF WATER AND WASTEWATER 19a edição, 1995), a fim de neutralizar o cloro residual excedente.

Para cada par dosagem - tempo de contato, eram retiradas amostras para as análises físico-químicas e exames microbiológicos, sendo as amostras coletadas em frascos plásticos, que a cada ensaio de desinfecção eram lavados abundantemente com água de torneira e a seguir com água destilada e retiradas amostras em frascos estéreis (autoclavados) para os exames microbiológicos.

As amostras de água bruta para as análises físico-químicas e exames microbiológicos eram retiradas antes dos ensaios de desinfecção.

\subsection{1 - Cloro residual}

As análises de cloro residual livre e total foram feitas pelo método DPD colorimétrico proposta pelo manual Hach DR 2000 Spectrophotometer Handbook e que também se encontra em STANDARD METHODS FOR THE EXAMINATION OF WATER AND WASTEWATER, 19a edição (1995). O cloro residual total e livre foram medidos respectivamente pelos reagentes DPD-cloro total AccuVac ${ }^{\circledR}$, Cat.25030-25 e DPD-cloro livre AccuVac ${ }^{\circledR}$, Cat 25020-25, ambos da HACH.

O método DPD colorimétrico é uma versão colorimétrica do método DPD titulométrico, porém, é baseado nos mesmos princípios. Ao invés da titulação com o padrão sulfato ferroso amoniacal (FAS), como no método titulométrico, um procedimento colorimétrico é usado. O cloro em amostra como ácido hipocloroso ou ion hipoclorito (cloro livre ou cloro livre disponível) imediatamente reage com indicador DPD (N,N-dietil-p-fenilenediamina) para formar uma coloração vermelha, a qual é proporcional à concentração de cloro. É necessário citar que deverá haver compensação para cor e turbidez pelo uso de amostra como "branco". 


\section{6 - Desinfecção com ácido peracético}

Os ensaios de desinfecção com ácido peracético foram realizados em instalação de batelada, de maneira análoga aos ensaios com cloro.

O produto usado para desinfecção com ácido peracético foi o PROXITANE 1512 adquirido da empresa Thech Desinfecção (Peróxidos) - São Paulo, SP.

Segundo descrição fornecida pelo fabricante, o PROXITANE 1512 é uma solução que varia de incolor a levemente amarelada, de odor forte e característico, constituída de ácido peracético, peróxido de hidrogênio, ácido acético e veículo estabilizante.

Em sua formulação comercial o produto apresenta a seguinte especificação:

\begin{tabular}{l|l}
\hline Ácido peracético & Mín 15\% \\
\hline Peróxido de hidrogênio & Mín 23\% \\
\hline Ácido acético & Máx 16\% \\
\hline Veículo estabilizante & $100 \%$ \\
\hline
\end{tabular}

O Proxitane 1512 foi diluído em água destilada estéril, de modo a se obter concentração final de $1000 \mathrm{mg} / \mathrm{L}$ de ácido peracético.

Da solução de $1000 \mathrm{mg} / \mathrm{L}$ eram retiradas aliquotas de forma a se obter as concentrações desejadas para os ensaios de desinfecção. O preparo da solução de $1000 \mathrm{mg} / \mathrm{L}$ era feito no momento do experimento.

Para confirmação da concentração da solução (1000 mg/L) usou-se o Kit Vacu-vials ${ }^{\circledR}$ (CHEMetrics), método colorimétrico de leitura fotométrica.

Para neutralizar o ácido peracético, após os tempos de contato especificados para os ensaios de desinfecção, foi utilizada solução de tiossulfato de sódio $3 \%$ na proporção de $0,1 \mathrm{~mL}$ para cada $100 \mathrm{~mL}$ de amostra. As dosagens e os tempos de contato, definidos após testes preliminares foram respectivamente: 2,$0 ; 3,0 ; 4,0$ e 5,0 mg/L e 5; 10; 15 e 20 minutos.

O procedimento adotado para os ensaios de desinfecção com ácido peracético foi análogo ao procedimento adotado para os ensaios com cloro. 
As análises físico-químicas e os exames microbiológicos foram realizados para a água bruta e após os ensaios de desinfecção.

\subsection{1 - Ácido peracético residual}

O ácido peracético residual foi medido usando o Kit Vacu-vials ${ }^{\circledR}$ (CHEMetrics), método colorimétrico de leitura fotométrica.

O método utilizado - o DDPD - desenvolvido e patenteado pela CHEMetrics, é uma derivação menos susceptivel à presença de interferentes que o método DPD.

$\mathrm{Na}$ metodologia DDPD a amostra é tratada com excesso de iodeto de potássio. O ácido peracético oxida o iodeto a iodo. Então, o iodo oxida o DDPD,

uma forma metil substituída do DPD, para formar um complexo púrpura de intensidade de cor em proporção direta com a concentração de ácido peracético.

\section{7 - Desinfecção com ozônio}

Os ensaios de desinfecção com ozônio foram realizados em batelada em unidade piloto instalada no Laboratório de Tratamento de Resíduos Orgânicos (LTR) junto ao Departamento de Hidráulica e Saneamento, EESC/USP.

O desenho esquemático da unidade piloto de ozonização é apresentado na Figura 4.6. 
(b)

(a)

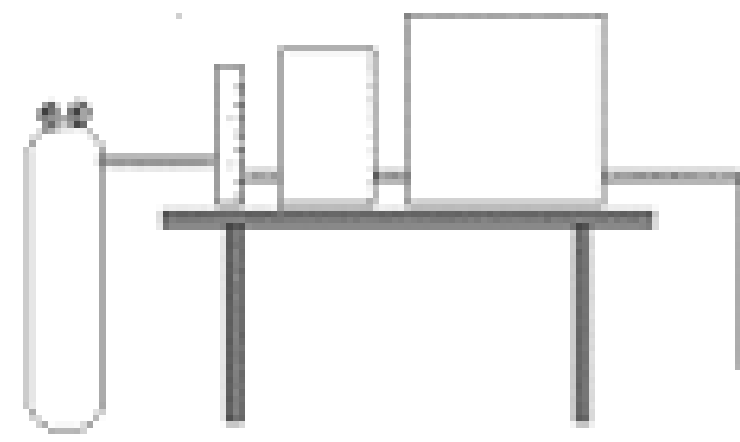

(e)

(c)

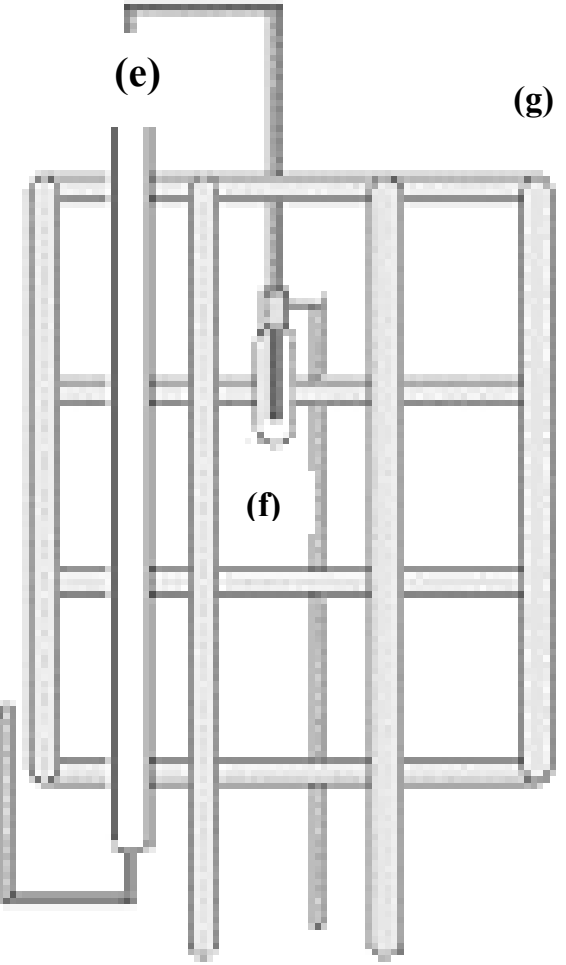

Figura 4.6 - Esquema da unidade piloto de ozonização.

Fonte: DIAS (2001).

A unidade piloto de ozonização era constituída por:

a) cilindro de oxigênio puro (98\%);

b) rotâmetro, para controle da vazão de oxigênio, com coluna de vidro graduada e um marcador esférico que flutuava na escala em função da vazão ajustada. A vazão variava de 0 a $400 \mathrm{~L} / \mathrm{h}$.

c) câmara de refrigeração, modelo Belliere, com serpentina interna imersa em água a $4{ }^{\circ} \mathrm{C}$;

d) gerador de ozônio modelo laboratorial, marca Qualid'or, nas dimensões $50 \mathrm{~cm}$ x $50 \mathrm{~cm}$ x $30 \mathrm{~cm}$, com capacidade máxima de produção de 8 $\mathrm{g} \mathrm{O}_{3} / \mathrm{h}$,

e) duas colunas de contato, em paralelo, uma para a água de estudo e outra para o KI, em acrílico, com $2 \mathrm{~m}$ de altura e $52 \mathrm{~mm}$ de diâmetro interno. 
As colunas possuiam na parte superior e inferior registros de esfera para preenchimento da coluna com a água de estudo e coleta da água ozonizada respectivamente. Ainda, na parte inferior da coluna, pedra porosa para difusão do ozônio.

f) frasco lavador de gás, em vidro, com capacidade para 1 L. Era preenchido com $600 \mathrm{~mL}$ de solução de iodeto de potássio (KI) a 2\% para avaliar a concentração de off-gas liberado após cada ensaio de ozonização.

g) grade metálica para fixação das colunas e do frasco lavador.

A água de estudo era adicionada à coluna de ozonização por meio de funil adaptado à parte superior da coluna. Eram empregados $2 \mathrm{~L}$ de água por ensaio. A distribuição do ozônio na fase líquida se dava por meio de uma pedra porosa situada na parte inferior da coluna. O ozônio que escapava da coluna de ozonização era destruído em solução de iodeto de potássio (2\%) na coluna paralela.

As dosagens aplicadas de ozônio foram obtidas ajustando-se o tempo de contato e a vazão de ar dada pelo rotâmetro. As dosagens aplicadas de ozônio foram de 2,0; 3,0; 4,0 e 5,0 mg/L e os tempos de contato empregados foram de $5 ; 10 ; 15$ e 20 minutos.

As dosagens efetivas de ozônio foram calculadas pela Equação (4.1):

Dosagem efetiva de ozônio $\left(\mathrm{mg} \mathrm{O}_{3} / \mathrm{L}\right)=$ Dose aplicada $-\left(\mathrm{O}_{3}\right.$ residual + off-gas $)$ (4.1)

Para obtenção das dosagens aplicadas de ozônio foi necessária a construção da curva de produção de ozônio dada pelo aparelho gerador. Tal produção foi quantificada variando-se a vazão de gás que passava pela coluna de contato contendo $\mathrm{KI}$ a $2 \%$ empregando titulometria com tiossulfato de sódio $(0,025 \mathrm{~N})$. As vazões de oxigênio adotadas para a confecção da curva foram de $5,10,20,30,60,100,150,200$ e $300 \mathrm{~L} / \mathrm{h}$ e o tempo de contato foi fixado em 10 minutos.

A produção de ozônio foi calculada usando a Equação (4.2): 


$$
P\left(g / h \mathrm{O}_{3}\right)=\frac{N_{\mathrm{Na}_{2} \mathrm{~S}_{2} \mathrm{O}_{3}} x \Delta V_{\mathrm{Na}_{2} \mathrm{~S}_{2} \mathrm{O}_{3}} x V K I x 14,4}{V_{\mathrm{am}} \times t}
$$

$\mathrm{N}$ Na2S2O3: normalidade do tiossulfato de sódio;

$\Delta \mathrm{V}$ Na2s2O3: volume de tiossulfato consumido na titulação da amostra - volume de tiossulfato consumido na titulação do branco;

$\mathrm{V}_{\mathrm{KI}}$ : volume de iodeto de potássio ozonizado;

$\mathrm{V}_{\mathrm{am}}$ : volume de amostra de iodeto de potássio titulada $(\mathrm{mL})$;

t: tempo de aplicação do ozônio (min).

A dosagem de ozônio foi calculada pela Equação 4.3.

$$
D=\frac{P_{x} t_{x} 100}{6 x V}
$$

P: produção de ozônio na coluna em g/h;

t: tempo de aplicação do ozônio em minutos;

$\mathrm{V}$ : volume da água ozonizada na coluna (L);

D: dosagem de ozônio $\left(\mathrm{mg} \mathrm{O}_{3} / \mathrm{L}\right)$

A partir da curva que relacionava a produção $(\mathrm{P})$ com a vazão de oxigênio (Q) determinava-se a vazão de oxigênio necessária para obtenção das dosagens aplicadas de ozônio.

Após os tempos de contato especificados, coletavam-se alíquotas da água ozonizada para realização das análises físico-químicas e dos exames microbiológicos. Do frasco lavador extraíam-se amostras para medição do ozônio que não reagiu. 


\subsection{1 - Ozônio residual}

A fração de ozônio excedente capturada no frasco lavador (off-gas) foi determinada pelo método iodométrico e a fração de ozônio residual presente na amostra foi determinada pelo método índigo colorimétrico, empregando espetrofotômetro HACH DR 2010. Os métodos iodométrico e índigo encontramse descritos em STANDARD METHODS FOR THE EXAMINATION OF WATER AND WASTEWATER (1995).

\section{8 - Desinfecção seqüencial: Ozônio / Cloro}

Os ensaios de desinfecção seqüencial: ozônio / cloro foram realizados em batelada, de maneira análoga aos ensaios com os dois desinfetantes individuais. O ozônio foi o desinfetante primário usado. A água de estudo ozonizada era coletada a partir da coluna de contato, em béqueres estéreis. $\mathrm{O}$ ozônio não foi neutralizado com qualquer agente redutor, antes da aplicação do cloro. Optou-se por não empregar agentes redutores, pois, em escala real, numa ETA, por exemplo, tal, seria inviável, tanto por motivos de ordem prática quanto econômica. Além disso, o ozônio é reconhecido por deixar residual extremamente instável na água.

Após os tempos de contato estabelecidos previamente para o estudo, o cloro, por deixar residual persistente na água, era inativado com tiossulfato de sódio (3\%) na proporção de 0,1 mL de tiossulfato para cada $100 \mathrm{~mL}$ de amostra clorada.

A desinfecção combinada ozônio / cloro foi realizada somente para a água de estudo com cor baixa. Os ensaios individuais foram realizados para as doses aplicadas de ozônio de 2,0; 3,0 e 5,0 mg/L; as doses de cloro foram de 2,0 e 5,0 mg/L; e a desinfecção seqüencial consistiu das seguintes combinações: $2,0 \mathrm{O}_{3}+2,0 \mathrm{Cl}_{2} ; 3,0 \mathrm{O}_{3}+2,0 \mathrm{Cl}_{2} ; 5,0 \mathrm{O}_{3}+2,0 \mathrm{Cl}_{2}$ e 2,0 $\mathrm{O}_{3}+5,0$ $\mathrm{Cl}_{2} \mathrm{mg} / \mathrm{L}$. Os tempos de contato empregados foram de 5, 10, 15 e 20 minutos de contato, tanto para os ensaios individuais como para a etapa seqüencial, sendo que, para a etapa seqüencial os tempos referidos foram divididos em 
intervalos aproximadamente iguais entre os dois desinfetantes, de forma que o tempo de contato final para a desinfecção combinada fosse de $5 ; 10 ; 15$ e 20 minutos.

Os exames microbiológicos (E. coli, colifagos e C. perfringens) foram realizados para a água de estudo sem a adição dos desinfetantes (água bruta), após as aplicações individuais do ozônio e do cloro e após a etapa de desinfecção seqüencial.

\section{9 - Métodos analíticos, exames, análises físico-químicas e equipamentos}

Após os ensaios de desinfecção foram realizadas as análises de $\mathrm{pH}$, alcalinidade, COD, Absorbância $254 \mathrm{~nm}$, concentrações residuais dos desinfetantes e THMs para alguns dos experimentos de desinfecção com cloro.

Para a água bruta, além das análises referidas anteriormente, foram monitorados os parâmetros cor e turbidez da água.

\subsection{1 - Carbono orgânico dissolvido (COD) e Absorbância UV- 254 nm}

Para as análises de COD e absorbância UV-254 nm amostras de $50 \mathrm{~mL}$ eram filtradas em membranas de nitrato de celulose de 0,45 $\mathrm{mm}$ de tamanho de poro, para remover o material particulado e a seguir acidificadas com ácido clorídrico.

O conteúdo de COD foi medido em equipamento SHIMADZU 5000 A. Para eliminação do carbono inorgânico todas as amostras eram purgadas com nitrogênio puro por 10 a 15 minutos, os resultados são expressos em mgC.L-1. Após as análises de COD as amostras já filtradas e acidificadas eram analisadas visando à absorção de luz no comprimento de onda de $254 \mathrm{~nm}$, em espectofotômetro SHIMADZU 160 A. 


\subsection{2 - Análises de THM}

As concentrações de THMs foram determinadas por cromatografia gasosa. O equipamento utilizado foi o cromatógrafo a gás HP 5890, equipado com detector de captura de elétrons e coluna HP-5 $30 \mathrm{~m}$ x 0,32 mm x 0,25 $\mu \mathrm{m}$. Para a realização das análises de THM seguiu-se o Método 551.1 (USEPA) modificado por HAUTMAN \& MUNCH (1997).

Em frascos de vidro de $60 \mathrm{~mL}$, devidamente calibrados, colocava-se $1 \mathrm{~g}$ da mistura denominada tampão seco, composta de $1 \% \quad \mathrm{Na}_{2} \mathrm{HPO}_{4}$ e $99 \%$ $\mathrm{KH}_{2} \mathrm{PO}_{4}$, com o objetivo de acidificar e preservar a amostra. Adicionava-se a amostra, preenchendo completamente os frascos $(60 \mathrm{~mL})$. Com auxílio de uma pipeta calibrada retirava-se $10 \mathrm{~mL}$ da amostra, descartando-a. A seguir, adicionava-se: $100 \mu \mathrm{L}$ do padrão interno, que consistia de solução de brometo de pentafluortolueno; $10 \mathrm{mg} / \mathrm{L} \mathrm{em} \mathrm{metanol;} \mathrm{5,0} \mathrm{mL}$ de $\mathrm{n}$-pentano que foi o solvente de extração empregado; e $10 \mathrm{~g}$ de sulfato de sódio anidro $\left(\mathrm{Na}_{2} \mathrm{SO}_{4}\right)$ que foi o sal de extração empregado.

Os frascos eram fechados com tampa de butila com teflon e lacrados. Agitava-se vigorosamente durante 2 minutos em agitador de tubos.

Com o auxílio de uma seringa, mantida no freezer, injetava-se $1 \mu \mathrm{L}$ da fase orgânica no cromatógrafo. O volume era retirado diretamente do frasco lacrado através da tampa de butila.

Os 4 THMs: o triclorometano (TCM), bromodiclorometano (BDCM), dibromoclorometano (DBCM) e tribromometano (TBM) foram monitorados após 20 minutos, 24 horas, 6, 12 e 30 dias.

A etapa de cromatografia das análises de THM foram realizadas no Laboratório de Processos Biológicos (LPB) da EESC-USP pelas técnicas Elisabeth de Matos Moraes e Maria Ângela Talarico Adorno.

\subsection{3 - Métodos analíticos e equipamentos}

Os métodos analíticos empregados para a realização dos exames e análises, bem como os equipamentos utilizados na pesquisa, estão sumarizados na Tabela 4.6. 
Tabela 4.6 - Métodos analíticos, exames, análises e equipamentos empregados durante os ensaios de desinfecção.

\begin{tabular}{|c|c|}
\hline PARÂMETRO & DESCRIÇÃO DO MÉTODO \\
\hline $\begin{array}{l}\text { Cloro residual livre e } \\
\text { total }\end{array}$ & $\begin{array}{l}\text { Método DPD colorimétrico, com utilização de kit da HACH } \\
\left(A C C U V A C^{\circledR}\right) \text { e leitura em espectrofotômetro DR } 2000\end{array}$ \\
\hline Ácido peracético & método colorimétrico - Kit Vacu-vials ${ }^{\circledR}$ (CHEMetrics) \\
\hline Ozônio residual & $\begin{array}{l}\text { Método iodométrico (titulometria) e método índigo } \\
\text { colorimétrico, empregando espetrofotômetro } \mathrm{HACH} \text { DR } \\
2010\end{array}$ \\
\hline Cor & $\begin{array}{l}\text { Filtração da amostra e leitura em espectrofotômetro DR } \\
4000 \text { em comprimento de onda } 455 \mathrm{~nm} \text {. }\end{array}$ \\
\hline Filtração & $\begin{array}{l}\text { Para filtração das amostras, quando exigida ou } \\
\text { recomendada pelos métodos analíticos, utilizou-se } \\
\text { membrana de nitrato de celulose com poros de } 0,45 \mu \mathrm{m} \text { de } \\
\text { diâmetro. }\end{array}$ \\
\hline Turbidez & Turbidimetro, marca HACH, modelo $2100 \mathrm{P}$ \\
\hline E. coli & $\begin{array}{l}\text { Técnica de filtração em membranas usando o meio } \\
\text { Chromocult }{ }^{\circledR} \text { Coliform Agar (Merck Cat.No.1.10426) }\end{array}$ \\
\hline Colifagos & $\begin{array}{l}\text { Contagem de unidades formadoras de placas (UFP/100 } \\
\mathrm{mL} \text { ) em placas de Petri. }\end{array}$ \\
\hline C. perfringens & $\begin{array}{l}\text { Técnica do número mais provável de unidades formadoras } \\
\text { de colônia (UFC/ } 100 \mathrm{~mL})\end{array}$ \\
\hline Alcalinidade & Titulométrico. \\
\hline $\mathrm{pH}$ & Pote \\
\hline Temperatura & Termômetro de vidro. \\
\hline $\begin{array}{l}\text { Absorvância em } \\
\text { comprimento de onda } \\
\text { de } 254 \mathrm{~nm}\end{array}$ & $\begin{array}{l}\text { Espectrofotômetro UV visível marca SHIMADZU, modelo } \\
160 \text { A (as amostras eram filtradas e acidificadas com ácido } \\
\text { clorídrico) }\end{array}$ \\
\hline COD & $\begin{array}{l}\text { Analisador de carbono orgânico total, marca SHIMADZU, } \\
\text { modelo TOC-5000 A. }\end{array}$ \\
\hline THM & $\begin{array}{l}\text { Cromatógrafo a gás HP 5890, equipado com detector de } \\
\text { coluna de elétrons e coluna HP-5 } 30 \mathrm{~m} \times 0,32 \mathrm{~mm} \times 0,25 \\
\mu \mathrm{m} \text {. }\end{array}$ \\
\hline
\end{tabular}




\section{5 - RESULTADOS E DISCUSSÃO}

\section{1 - Desinfecção com cloro}

Nos ensaios de desinfecção com cloro, estudou-se o efeito da concentração de 2,0; 3,0; 4,0 e 5,0 mg/L e tempos de contato de 5, 10, 15 e 20 minutos na inativação dos microrganismos E. coli, colifagos e C. perfringens realizados para duas águas de estudo, uma com cor baixa (aproximadamente 5 $\mathrm{uH}$ ) e outra com cor elevada (aproximadamente $100 \mathrm{uH}$ ).

\subsection{1 - Inativação de $E$. coli, colifagos e C. perfringens}

Os resultados de inativação de E. coli, colifagos e C. perfringens obtidos nos ensaios de desinfecção com cloro para a água de estudo com cor baixa estão apresentados na Tabela 5.1 e para a água de estudo com cor elevada na Tabela 5.2. Para cada concentração de cloro aplicado - 2,0; 3,0; 4,0 e 5,0 mg/L - nos progressivos tempos de contato de 5, 10, 15 e 20 minutos foram quantificadas as concentrações finais $(\mathrm{N})$ dos microrganismos indicadores: $E$. coli (UFC/100 mL), colifagos (UFP/100 ml) e C. perfringens (NMP/100 mL). A concentração inicial (No) de microrganismos adicionados à água foi variável conforme a água de estudo. 
Tabela 5.1 - Inativação de E. coli, colifagos e C. perfringens em função do tempo de contato e concentração residual de cloro para água de estudo com cor baixa.

\begin{tabular}{|c|c|c|c|c|c|c|c|c|}
\hline \multirow{2}{*}{$\begin{array}{c}\text { Cloro } \\
\text { aplicado } \\
(\mathrm{mg} / \mathrm{L})\end{array}$} & \multirow{2}{*}{$\begin{array}{c}\text { Tempo } \\
\text { de } \\
\text { contato } \\
\text { (min) }\end{array}$} & \multicolumn{2}{|c|}{ E. coli } & \multicolumn{2}{|c|}{ Colifagos } & \multicolumn{2}{|c|}{ C. perfringens } & \multirow{2}{*}{$\begin{array}{c}\text { Cloro } \\
\text { residual } \\
\text { combinado } \\
(\mathrm{mg} / \mathrm{L})\end{array}$} \\
\hline & & (N/No) & Inativação & (N/No) & Inativação & (N/No) & Inativação & \\
\hline \multirow{4}{*}{2,0} & 5 & $1,0 \times 10^{-2}$ & 2,00 & $1,0 \times 10^{-2}$ & 1,00 & $5,0 \times 10^{-2}$ & 1,30 & 1,96 \\
\hline & 10 & $1,0 \times 10^{-2}$ & 2,00 & $1,0 \times 10^{-2}$ & 1,00 & $6,0 \times 10^{-2}$ & 1,22 & 1,66 \\
\hline & 15 & $1,0 \times 10^{-2}$ & 2,00 & $1,0 \times 10^{-2}$ & 1,00 & $5,0 \times 10^{-2}$ & 1,30 & 1,93 \\
\hline & 20 & $1,0 \times 10^{-2}$ & 2,00 & $1,0 \times 10^{-2}$ & 1,00 & $6,0 \times 10^{-2}$ & 1,22 & 1,96 \\
\hline \multirow{4}{*}{3,0} & 5 & $9,0 \times 10^{-2}$ & 1,04 & $1,0 \times 10^{-2}$ & 2,00 & $4,0 \times 10^{-2}$ & 1,39 & 2,76 \\
\hline & 10 & $4,0 \times 10^{-2}$ & 1,39 & $1,2 \times 10^{-2}$ & 1,92 & $3,0 \times 10^{-2}$ & 1,52 & 2,57 \\
\hline & 15 & $5,0 \times 10^{-4}$ & 3,30 & $1,0 \times 10^{-2}$ & 2,00 & $1,0 \times 10^{-2}$ & 2,00 & 2,57 \\
\hline & 20 & $3,0 \times 10^{-4}$ & 3,52 & $5,0 \times 10^{-3}$ & 2,30 & $1,0 \times 10^{-2}$ & 2,00 & 2,48 \\
\hline \multirow{4}{*}{4,0} & 5 & $1,9 \times 10^{-1}$ & 0,72 & $3,8 \times 10^{-1}$ & 0,43 & $4,0 \times 10^{-2}$ & 1,39 & 3,75 \\
\hline & 10 & $2,5 \times 10^{-3}$ & 2,60 & $4,5 \times 10^{-2}$ & 1,35 & $4,0 \times 10^{-2}$ & 1,39 & 3,63 \\
\hline & 15 & $5,0 \times 10^{-4}$ & 3,30 & $8,2 \times 10^{-1}$ & 0,08 & $2,0 \times 10^{-2}$ & 1,69 & 3,64 \\
\hline & 20 & $1,0 \times 10^{-2}$ & 2,00 & $9,5 \times 10^{-1}$ & 0,02 & $4,0 \times 10^{-2}$ & 1,39 & 3,45 \\
\hline \multirow{4}{*}{5,0} & 5 & $1,0 \times 10^{-2}$ & 2,00 & ND & ND & 1,0 & 0 & 4,54 \\
\hline & 10 & $1,0 \times 10^{-2}$ & 2,00 & ND & ND & $6,0 \times 10^{-2}$ & 1,22 & 4,25 \\
\hline & 15 & $1,0 \times 10^{-2}$ & 2,00 & ND & ND & $1,4 \times 10^{-1}$ & 0,85 & 4,26 \\
\hline & 20 & $1,0 \times 10^{-2}$ & 1,15 & ND & ND & $4,4 \times 10^{-1}$ & 0,36 & 4,46 \\
\hline
\end{tabular}

Inativação:- $\log (\mathrm{N} / \mathrm{No})$; N: número de microorganismos no instante t; No: número de microrganismos no instante $\mathrm{t}=0$.

ND: não detectado, ou menor que o limite de detecção do método empregado. 
Tabela 5.2 - Inativação de E. coli, colifagos e C. perfringens em função do tempo de contato e concentração residual de cloro para água de estudo com cor elevada.

\begin{tabular}{|c|c|c|c|c|c|c|c|c|}
\hline \multirow{2}{*}{$\begin{array}{c}\text { Cloro } \\
\text { aplicado } \\
(\mathrm{mg} / \mathrm{L})\end{array}$} & \multirow{2}{*}{$\begin{array}{c}\text { Tempo } \\
\text { de } \\
\text { contato } \\
\text { (min) }\end{array}$} & \multirow[b]{2}{*}{ (N/No) } & coli & \multicolumn{2}{|c|}{ Colifagos } & \multicolumn{2}{|c|}{ C.perfringens } & \multirow{2}{*}{$\begin{array}{c}\text { Cloro } \\
\text { residual } \\
\text { combinado } \\
(\mathrm{mg} / \mathrm{L})\end{array}$} \\
\hline & & & Inativação & (N/No) & Inativação & & Inativação & \\
\hline \multirow{4}{*}{2,0} & 5 & $5,0 \times 10^{-2}$ & 1,30 & $1,5 \times 10^{-2}$ & 1,82 & $6,6 \times 10^{-2}$ & 1,18 & 1,39 \\
\hline & 10 & $7,0 \times 10^{-3}$ & 2,15 & $1,5 \times 10^{-2}$ & 1,82 & $5,6 \times 10^{-2}$ & 1,25 & 1,39 \\
\hline & 15 & $5,0 \times 10^{-3}$ & 2,30 & $1,5 \times 10^{-2}$ & 1,82 & $2,2 \times 10^{-2}$ & 1,65 & 1,36 \\
\hline & 20 & $1,3 \times 10^{-3}$ & 2,89 & $5,0 \times 10^{-3}$ & 2,30 & $1,6 \times 10^{-2}$ & 1,80 & 1,31 \\
\hline \multirow{4}{*}{3,0} & 5 & $3,0 \times 10^{-2}$ & 1,52 & $1,0 \times 10^{-1}$ & 1,00 & $3,0 \times 10^{-1}$ & 0,52 & 2,44 \\
\hline & 10 & $1,0 \times 10^{-2}$ & 2,00 & $1,0 \times 10^{-1}$ & 1,00 & $1,1 \times 10^{-1}$ & 0,96 & 2,40 \\
\hline & 15 & $5,0 \times 10^{-3}$ & 2,30 & $7,0 \times 10^{-2}$ & 1,15 & $1,1 \times 10^{-1}$ & 0,96 & 1,91 \\
\hline & 20 & $3,0 \times 10^{-2}$ & 1,52 & $3,3 \times 10^{-3}$ & 2,48 & $5,0 \times 10^{-2}$ & 1,30 & 1,88 \\
\hline \multirow{4}{*}{4,0} & 5 & $4,0 \times 10^{-2}$ & 1,40 & $3,5 \times 10^{-2}$ & 1,46 & $6,6 \times 10^{-2}$ & 1,18 & 3,32 \\
\hline & 10 & $2,0 \times 10^{-2}$ & 1,70 & $2,1 \times 10^{-2}$ & 1,68 & $6,6 \times 10^{-2}$ & 1,18 & 3,23 \\
\hline & 15 & $1,1 \times 10^{-2}$ & 1,96 & $1,6 \times 10^{-2}$ & 1,80 & $6,6 \times 10^{-2}$ & 1,18 & 2,78 \\
\hline & 20 & $9,0 \times 10^{-3}$ & 2,05 & $2,5 \times 10^{-2}$ & 1,60 & $6,6 \times 10^{-2}$ & 1,18 & 2,60 \\
\hline \multirow{4}{*}{5,0} & 5 & $3,0 \times 10^{-2}$ & 1,52 & $7,5 \times 10^{-4}$ & 3,12 & $6,0 \times 10^{-2}$ & 1,22 & 3,81 \\
\hline & 10 & $2,0 \times 10^{-2}$ & 1,70 & $4,9 \times 10^{-4}$ & 3,31 & $2,0 \times 10^{-2}$ & 1,70 & 3,99 \\
\hline & 15 & $2,0 \times 10^{-3}$ & 2,70 & $2,4 \times 10^{-4}$ & 3,61 & $6,6 \times 10^{-2}$ & 1,18 & 3,47 \\
\hline & 20 & $1,0 \times 10^{-3}$ & 3,00 & $4,9 \times 10^{-5}$ & 4,31 & $6,6 \times 10^{-2}$ & 1,18 & 3,52 \\
\hline
\end{tabular}

Inativação: - $\log (\mathrm{N} / \mathrm{No})$; $\mathrm{N}$ : número de microorganismos no instante t; No: número de microrganismos no instante $\mathrm{t}=0$.

ND: não detectado.

A partir das frações sobreviventes de E. coli, colifagos e C. perfringens, obtidas experimentalmente, foram construídos os gráficos de inativação dos microrganismos indicadores relacionando $\log \mathrm{N} / \mathrm{N}_{0}$ em função do produto C.t concentração residual de cloro combinado (C) pelo tempo de contato $(t)$ usando como origem o tempo $t=0$ correspondente ao tempo de aplicação do 
cloro na água. As Figuras 5.1 a 5.4 referem-se à água de estudo com cor baixa e as Figuras de 5.5 a 5.8 à água de estudo com cor elevada.

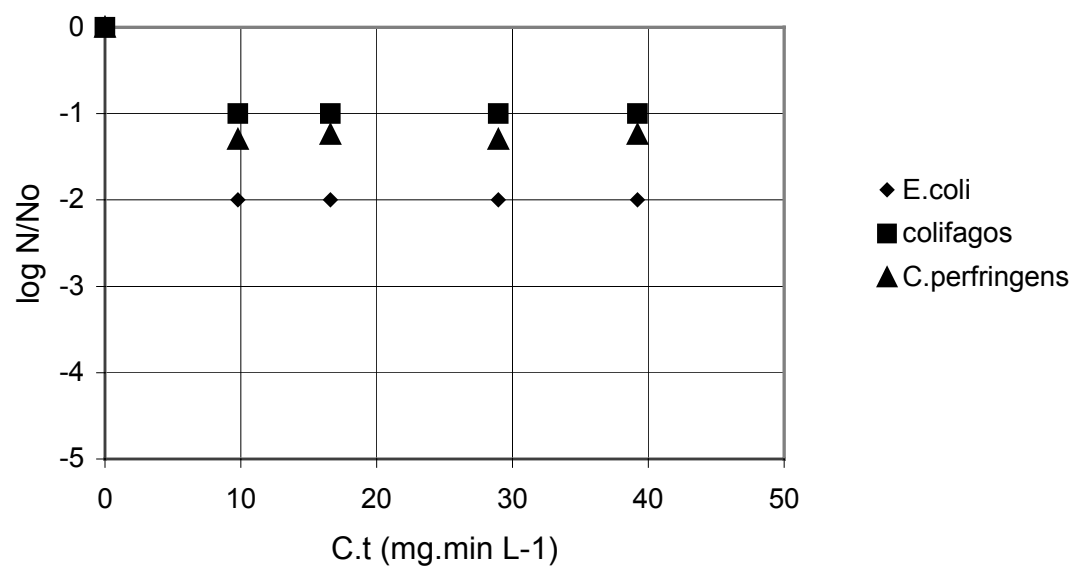

Figura 5.1- Inativação de E. coli, colifagos e C.perfringens para 2,0 mg/L de cloro aplicado (cor baixa).

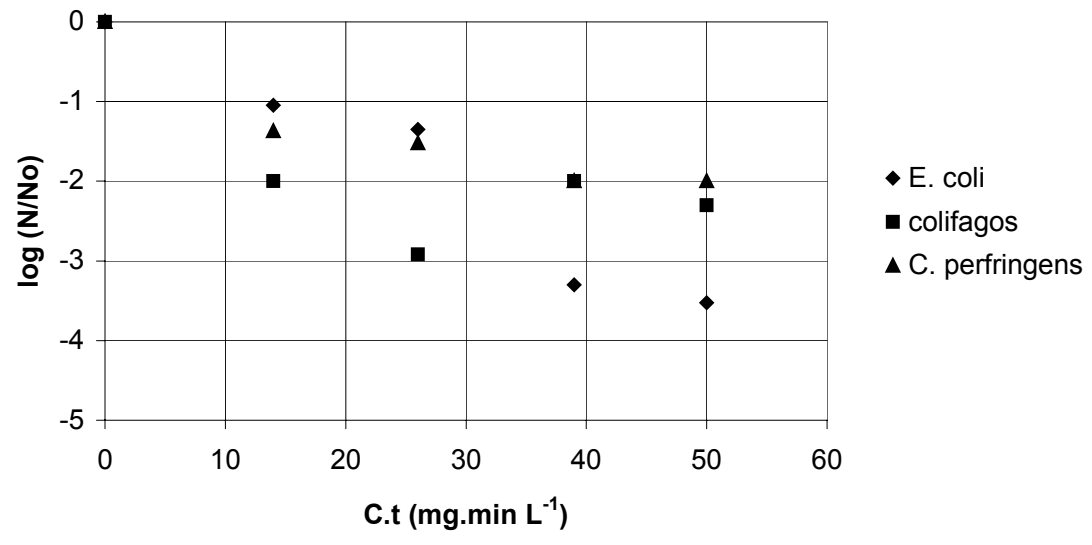

Figura 5.2 - Inativação de E. coli, colifagos e C.perfringens para 3,0 mg/L de cloro aplicado (cor baixa). 


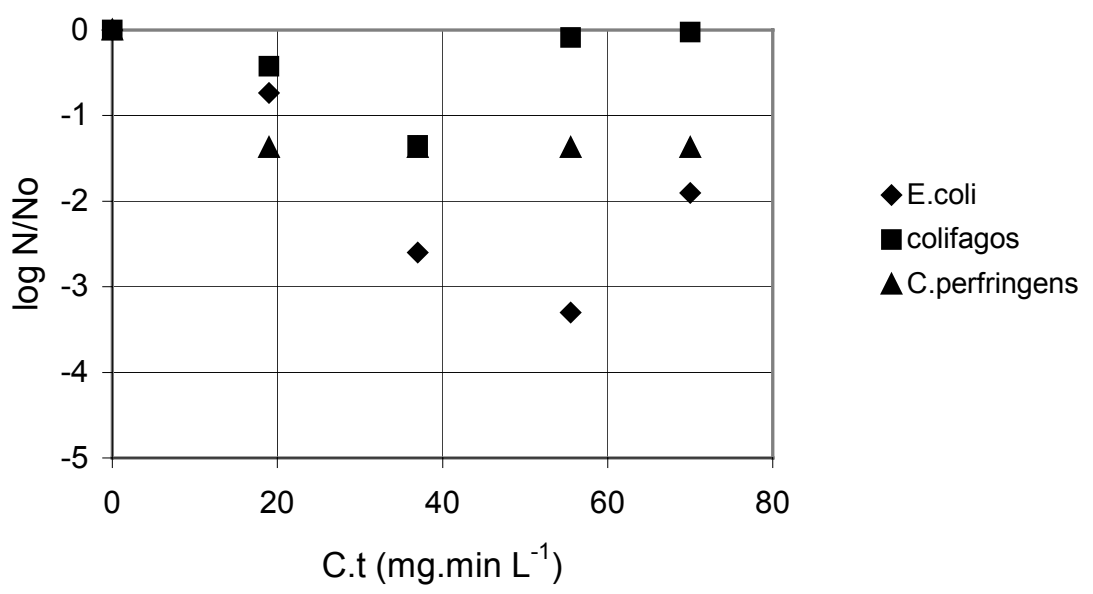

Figura 5.3 - Inativação de E.coli, colifagos e C.perfringens para 4,0 mg/L de cloro aplicado (cor baixa).

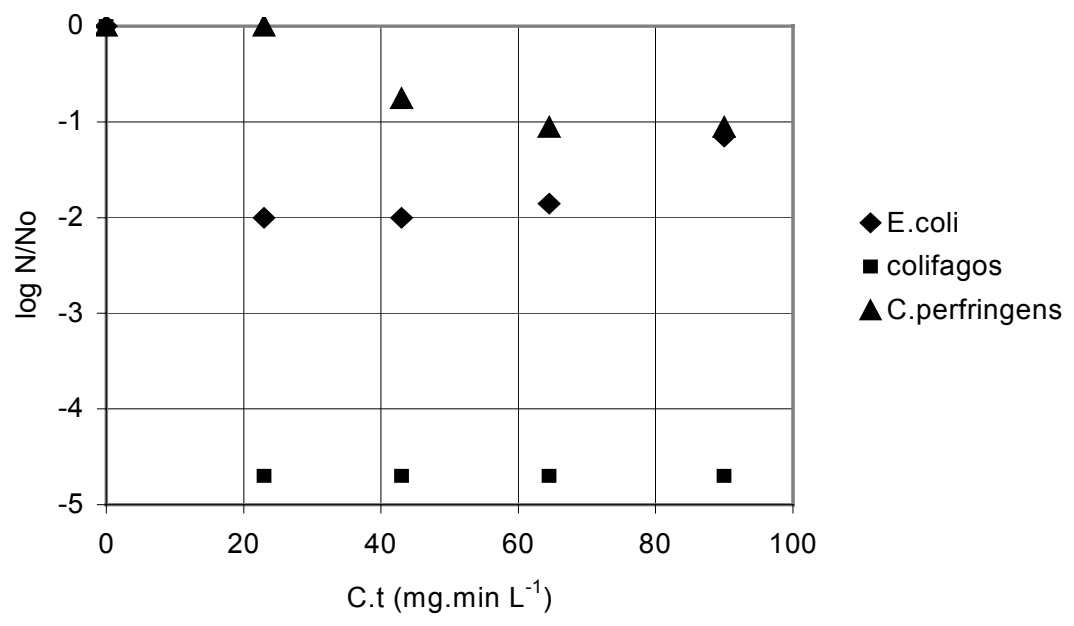

Figura 5.4 - Inativação de E. coli, colifagos e C.perfringens para 5,0 mg/L de cloro aplicado (cor baixa). 


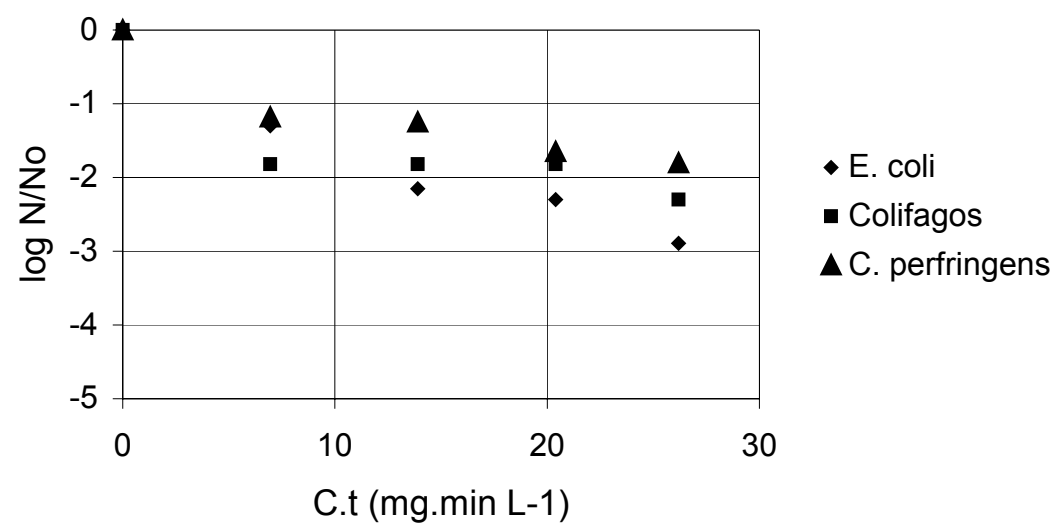

Figura 5.5 - Inativação de E. coli, colifagos e C.perfringens para 2,0 mg/L de cloro aplicado (cor elevada).

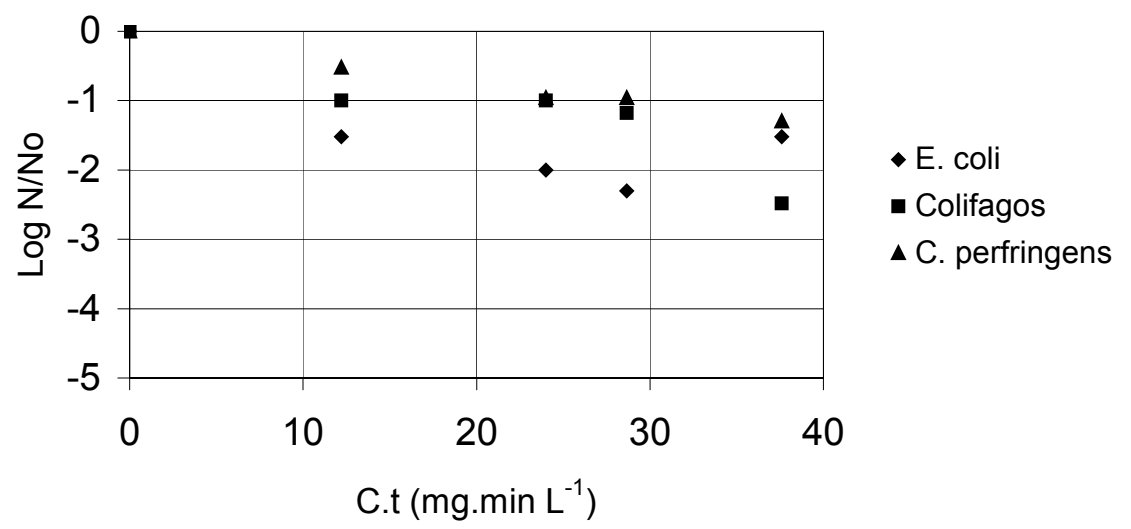

Figura 5.6 - Inativação de E. coli, colifagos e C.perfringens para 3,0 mg/L de cloro aplicado (cor elevada). 


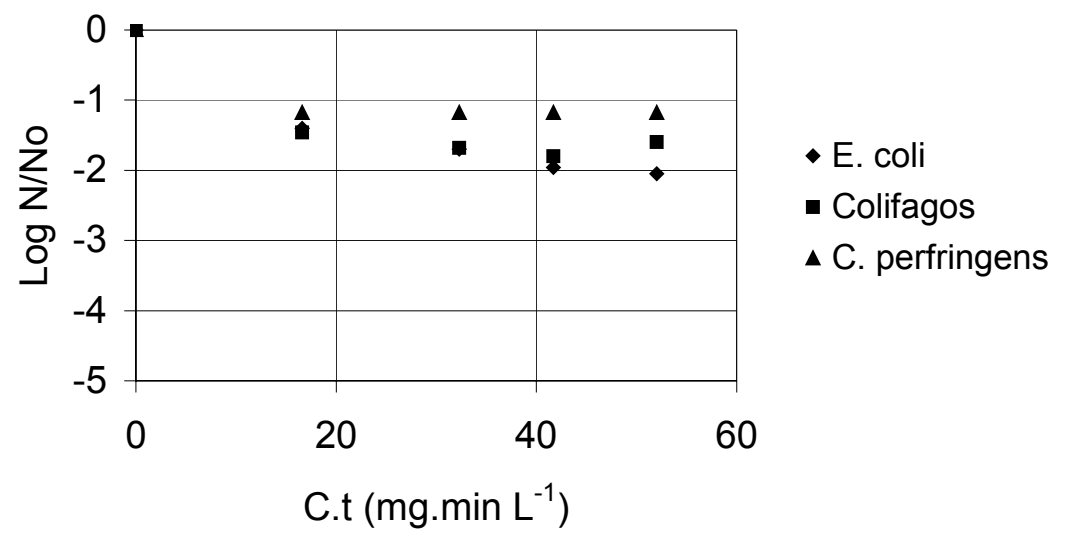

Figura 5.7 - Inativação de E.coli, colifagos e C.perfringens para 4,0 mg/L de cloro aplicado (cor elevada).

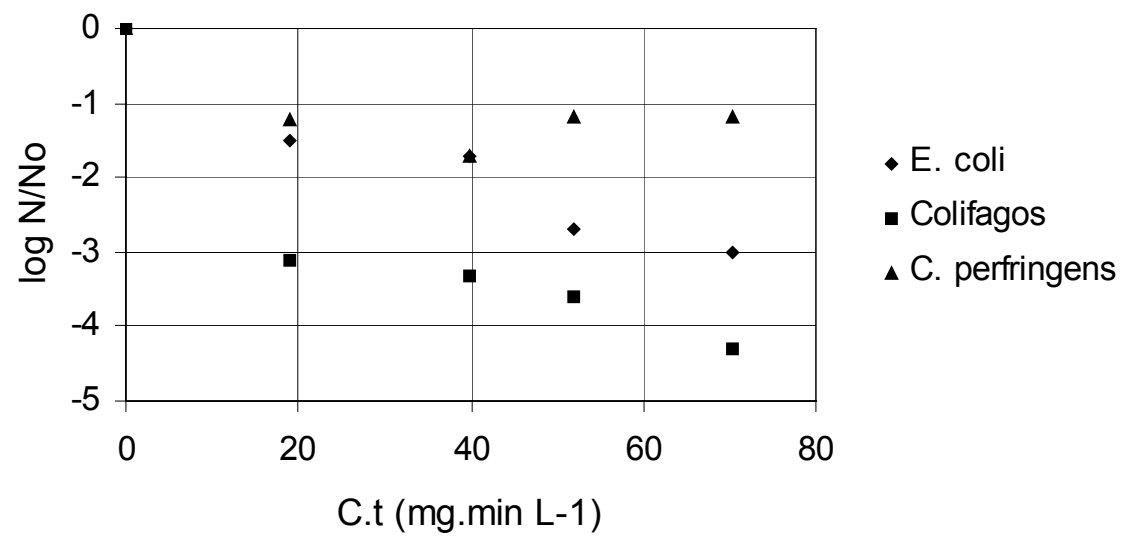

Figura 5.8 - Inativação de E.coli, colifagos e C.perfringens para 5,0 mg/L de cloro aplicado (cor elevada). 


\section{Água com cor baixa $(\approx 5 \mathrm{uH})$ :}

Para a concentração de $2,0 \mathrm{mg} / \mathrm{L}$ de cloro aplicado a inativação de $E$. coli e colifagos foi de 2,0 log e 1,0 log, respectivamente, independente do tempo de contato. C. perfringens apresentou inativações de 1,24 log para os tempos de contato e 10 e 20 minutos e 1,30 log para os tempos de 5 e 15 minutos.

Para a concentração de cloro aplicado de 3,0 mg/L obteve-se 3,52 log de inativação de E.coli em 20 minutos de contato, 2,92 log de inativação de colifagos em 10 minutos de contato e 2,00 log de inativação de C. perfringens para os tempos de contato de 15 e 20 minutos. Foram as maiores inativações obtidas para os três microrganismos nas concentrações de cloro e tempos de contato empregados para a água de estudo com cor baixa.

Para $4 \mathrm{mg} / \mathrm{L}$ de cloro aplicado a maior inativação de E. coli foi de 3,30 log para o tempo de contato de 15 minutos, para os fagos foi de 1,35 log para tempo de 10 minutos e para C. perfringens, foi de 1,69 log para o tempo de 15 minutos.

A maior concentração de cloro aplicada, $5 \mathrm{mg} / \mathrm{L}$, não foi a mais efetiva para a inativação da bactéria $E$. coli, com apenas 2,00 log de inativação para os três primeiros tempos de contato empregados, e inativação de 1,15 log para o tempo de contato de 20 minutos.

Por sua vez, para os fagos, a dosagem aplicada de $5 \mathrm{mg} / \mathrm{L}$ de cloro, foi bastante efetiva, atingindo inativações maiores que o limite de detecção do método empregado. Ou seja, dos fagos adicionados à água de estudo $5 \times 10^{4} \mathrm{UFP} / 100 \mathrm{~mL}-100 \%$ foram inativados para essa dosagem nos tempos de contato empregados.

A inativação de C. perfringens não foi significativa para essa última dosagem em qualquer tempo de contato empregado. 


\section{Água com cor elevada ( $\approx 100 \mathrm{uH})$ :}

Para a dose de cloro aplicada de $2,0 \mathrm{mg} / \mathrm{L}$ o maior tempo de contato $(20$ minutos) foi o mais efetivo para as inativações de E. coli $(2,89 \mathrm{log})$, fagos $(2,30$ log) e C. perfringens $(1,80 \mathrm{log})$.

Para a dose de $3,0 \mathrm{mg} / \mathrm{L}$ a maior inativação de $E$. coli foi de 2,30 log para o tempo de contato de 15 minutos. As maiores inativações de fagos $(2,48$ log) e C. perfringens (1,30 log) ocorreram para o tempo de contato de 20 minutos.

Para a dose de $4 \mathrm{mg} / \mathrm{L}$ os maiores tempos de contato também foram mais efetivos para obtenção das inativações de $E$. coli mais elevadas, sendo que a maior inativação observada foi de 2,05 log para o tempo de contato de 20 minutos. A maior inativação de fagos foi de 1,80 log, obtida para o tempo de 15 minutos, e a população de C. perfringens permaneceu estável ao longo dos tempos de contato empregados, com inativação de 1,18 log.

Também para a dose de $5 \mathrm{mg} / \mathrm{L}$ as maiores inativações de $E$. coli e fagos foram obtidas para os tempos de contato mais elevados. Exceto para a bactéria C. perfringens em que se verificou pequeno decaimento em sua inativação para os maiores tempos de contato de 15 e 20 minutos.

De modo geral, para as duas águas de estudo observou-se grande variabilidade nos resultados de inativação de E.coli, colifagos e C. perfringens nos ensaios com cloro para as diferentes dosagens e tempos de contato empregados. O aumento das concentrações de cloro aplicadas ao longo dos tempos de contato, não significou necessariamente em melhoria nas eficiências de inativação dos microrganismos indicadores.

Ocorreu que maiores concentrações de cloro aplicadas em tempos de contato superiores foram muitas vezes menos eficientes na inativação microbiana. 


\subsection{2 - Consumo de cloro}

A grande variabilidade, os desvios nos resultados obtidos, bem como a baixa capacidade de inativação verificadas nos ensaios com cloro foram possivelmente devido à matéria orgânica adicionada à água de estudo proveniente dos meios de cultura usados para crescimento e/ou preservação dos microrganismos indicadores - e a conseqüente competição entre as reações de oxi-redução e de substituição quando o cloro é aplicado na água.

Foi adicionado em $10 \mathrm{~L}$ de água de poço, $3 \mathrm{~mL}$ de suspensão bacteriana de E. coli em seu meio de cultivo TSB, em concentrações de aproximadamente $10^{6}$ a $10^{7}$ organismos / mL, $3 \mathrm{~mL}$ de suspensão bacteriana de C. perfringens em seu correspondente meio DRCM, em concentrações semelhantes $\left(\begin{array}{ll}10^{6} & \text { a } 10^{7}\end{array}\right.$ organismos/ $\mathrm{mL}$ ) e $3 \mathrm{~mL}$ de suspensão de colifagos em meio TSB nas concentrações de aproximadamente $10^{5}$ a $10^{6}$ organismos $/ \mathrm{mL}$, além de aliquotas variáveis de solução de substância húmica para a geração de cor.

O rápido e intenso consumo de cloro livre, verificado para a água de estudo em questão, foi atribuído ao material orgânico inerente aos meios de cultura empregados — material rico em nutrientes necessários ao crescimento celular, e adicionados à água como suspensões de microrganismos — além da substância húmica extraída de solo turfoso.

De fato, verificou-se pequena atividade antimicrobiana do cloro, especificamente nesse estudo, vale ressaltar, e atribuiu-se tal resultado ao comportamento tomado pelo cloro quando adicionado à água com alta concentração de matéria orgânica. Ressalvadas as diferenças inerentes a cada estudo, os resultados obtidos foram comparados com outros sobre cloração de culturas puras.

SHANG \& BLATCHLEY (2000) estudaram o destino e a distribuição do cloro em soluções aquosas de culturas puras de bactérias. As soluções foram submetidas à cloração em diferentes concentrações iniciais de cloro livre. As concentrações residuais de cloro foram determinadas pelos métodos de titulação DPD/FAS e espectrometria de massa (MIMS). Curvas de cloração ao 
breakpoint 'falso-positivas' foram observadas, provavelmente devido à formação de compostos cloro-orgânico-nitrogenados. O cloro livre foi observado em quantidades similares pelos dois métodos, DPD/FAS e MIMS, após a demanda ter sido satisfeita pelo material celular das bactérias na solução. Os resultados indicaram a existência de cloramina residual na forma de cloramina orgânica, sendo que esses compostos são geralmente reconhecidos como agentes antimicrobianos pouco efetivos. Além disso, investigações confirmaram que as células das bactérias foram a fonte dos compostos orgânico contendo nitrogênio. A cinética da cloração de suspensões de culturas puras de bactérias foi também estudada e indicou rápido consumo inicial de cloro livre e posteriormente consumo mais lento, com formação de traços de cloramina inorgânica.

No presente trabalho, foram medidos simultaneamente o cloro livre residual e o cloro total residual, ambos pelo método DPD colorimétrico. O cloro combinado residual foi calculado como a diferença entre as concentrações residuais de cloro total e cloro livre. Assim, não foram determinadas sob quais formas (monocloramina, dicloroamina ou tricloroamina) o cloro combinado estava presente nas amostras.

Para o cálculo do C.t empregado nos gráficos de inativação dos microrganismos, foi usada a concentração de cloro residual combinado.

Os resultados dos residuais de cloro livre e total ao longo dos tempos de contato $5,10,15$ e 20 minutos para as concentrações de cloro aplicadas 2,0; 3,$0 ; 4,0$ e $5,0 \mathrm{mg} / \mathrm{L}$, para as duas águas de estudo, cor baixa e cor elevada, estão apresentados nas Figuras 5.9 a 5.16. 


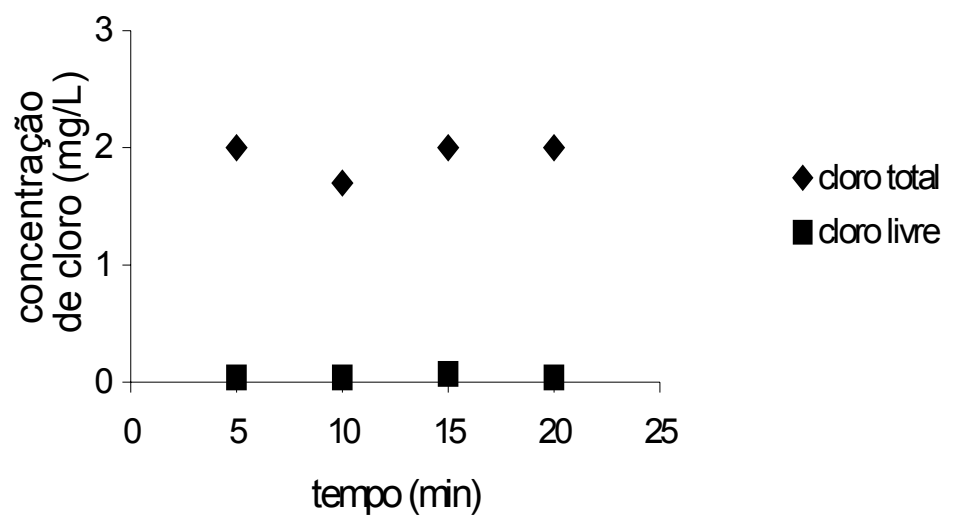

Figura 5.9- Cloro residual livre e total em função do tempo de contato, para 2,0 mg/L de cloro aplicado (água cor baixa).

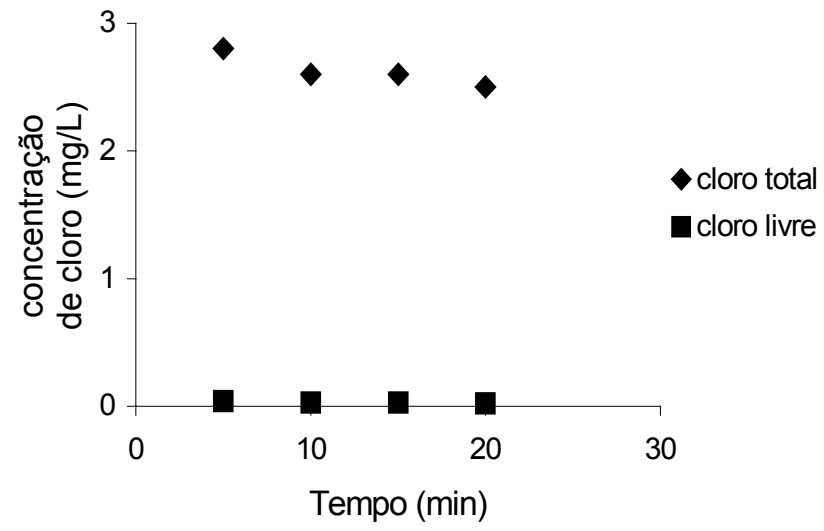

Figura 5.10- Cloro residual livre e total em função do tempo de contato, para 3,0 mg/L de cloro aplicado (água cor baixa). 


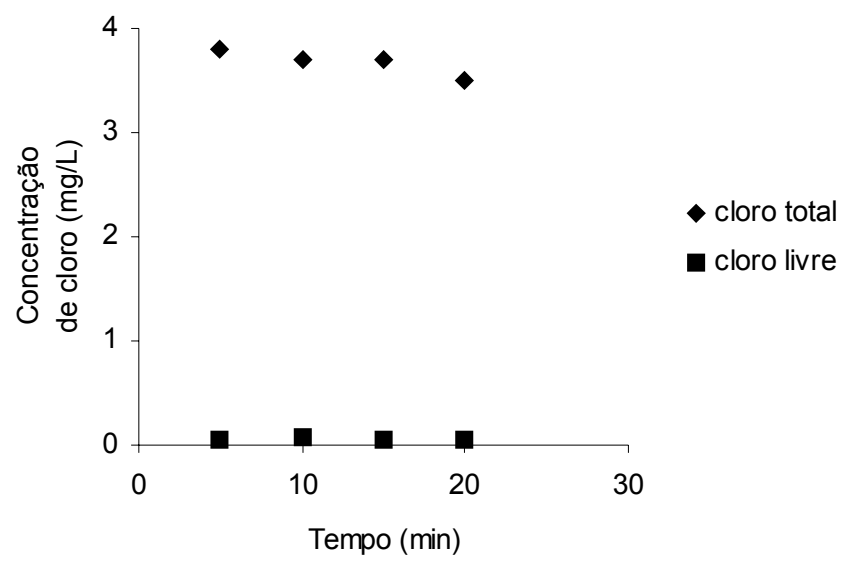

Figura 5.11- Cloro residual livre e total em função do tempo de contato, para 4,0 mg/L de cloro aplicado (água cor baixa).

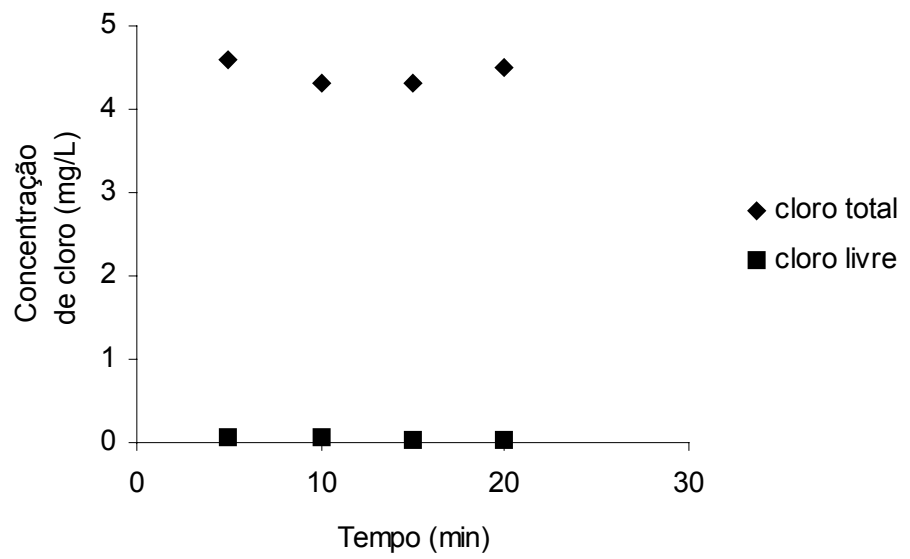

Figura 5.12- Cloro residual livre e total em função do tempo, para 5,0 mg/L de cloro aplicado (água cor baixa). 


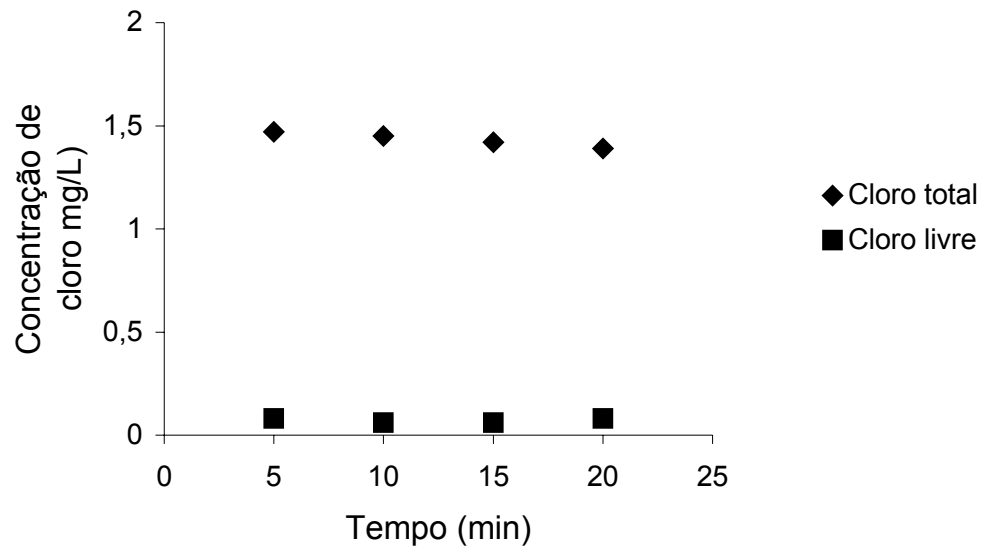

Figura 5.13- Cloro residual livre e total em função do tempo, para 2,0 mg/L de cloro aplicado (água cor elevada).

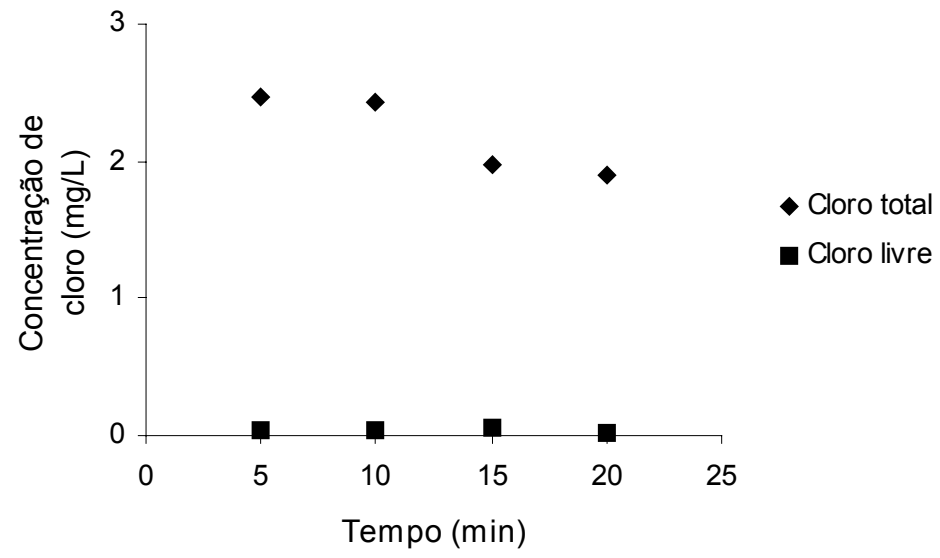

Figura 5.14- Cloro residual livre e total em função do tempo, para $3,0 \mathrm{mg} / \mathrm{L}$ de cloro aplicado (água cor elevada). 


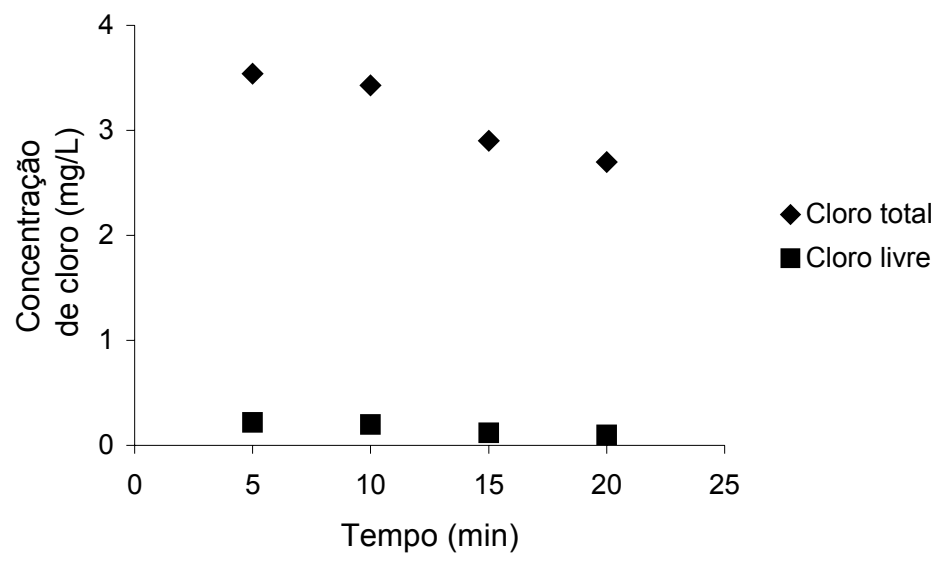

Figura 5.15- Cloro residual livre e total em função do tempo, para 4,0 mg/L de cloro aplicado (água cor elevada).

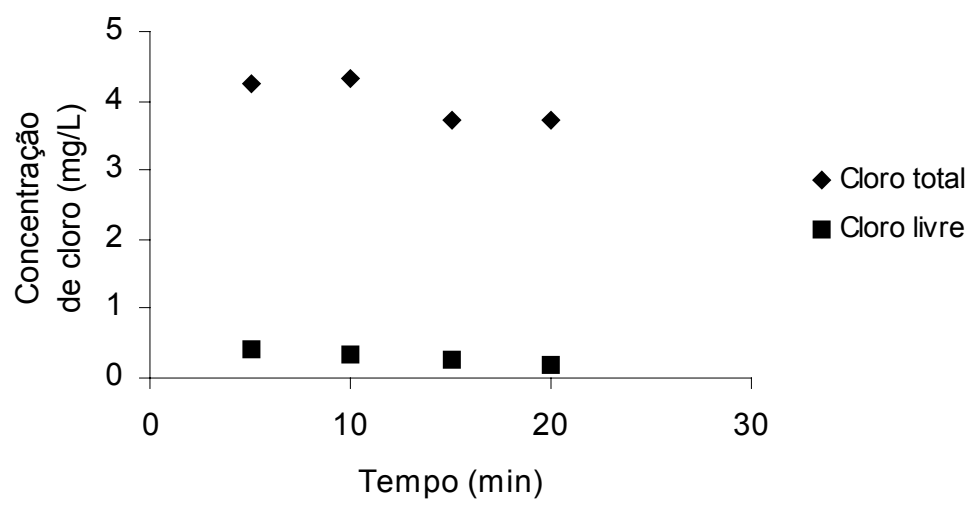

Figura 5.16- Cloro residual livre e total em função do tempo, para 5,0 mg/L de cloro aplicado (água cor elevada).

Os resultados apresentados nas Figuras 5.9 a 5.16 possibilitam concluir sobre o elevado consumo de cloro livre e a transformação do cloro aplicado em cloro combinado (verificado pelas medidas dos residuais de cloro total e cloro livre).

Provavelmente, o principal fator responsável por esta reação tenha sido a presença dos compostos orgânico-nitrogenados nos meios de cultura e nas células dos microrganismos que, segundo a literatura, quando adicionados à 
água em altas concentrações, como foi o caso do experimento, exercem significativa demanda de cloro.

A pequena atividade de inativação do cloro observada nesse estudo deveu-se à transformação de quase todo o cloro aplicado em formas de cloro combinado que, reconhecidamente, possuem menor capacidade de inativação de microrganismos.

\subsection{3 - Carbono Orgânico Dissolvido (COD) e Absorbância UV - 254 nm}

As amostras de água bruta e desinfetada eram filtradas antes das análises de carbono orgânico, assim, entende-se que a melhor denominação para os resultados seja carbono orgânico dissolvido e não carbono orgânico total (COT). Também para as análises de absorbância UV-254 nm as amostras eram filtradas anteriormente. Os resultados das análises de COD e Abs UV $254 \mathrm{~nm}$ para os ensaios de desinfecção com cloro para as duas águas de estudo são apresentados nas Tabelas 5.3 e 5.4, respectivamente. 
Tabela 5.3 - Análises de COD e Abs UV-254 nm para desinfecção com cloro (água com cor baixa).

\begin{tabular}{c|c|c|c|c|c|c|c|c}
\hline \multirow{2}{*}{$\begin{array}{c}\mathrm{T} \\
(\mathrm{min})\end{array}$} & \multicolumn{2}{|c|}{$\mathrm{Cl}_{2}: 2 \mathrm{mg} / \mathrm{L}$} & \multicolumn{2}{c|}{$\mathrm{Cl}_{2}: 3 \mathrm{mg} / \mathrm{L}$} & \multicolumn{2}{c|}{$\mathrm{Cl}_{2}: 4 \mathrm{mg} / \mathrm{L}$} & \multicolumn{2}{c}{$\mathrm{Cl}_{2}: 5 \mathrm{mg} / \mathrm{L}$} \\
\cline { 2 - 9 } & $\mathrm{COD}$ & $\begin{array}{c}\mathrm{UV} \\
(\mathrm{mg} / \mathrm{L})\end{array}$ & $\begin{array}{c}\mathrm{COD} \\
(\mathrm{mg} / \mathrm{L})\end{array}$ & $\begin{array}{c}\mathrm{UV} \\
254 \mathrm{~nm}\end{array}$ & $\begin{array}{c}\mathrm{COD} \\
(\mathrm{mg} / \mathrm{L})\end{array}$ & $\begin{array}{c}\mathrm{UV} \\
254 \mathrm{~nm}\end{array}$ & $\begin{array}{c}\mathrm{COD} \\
(\mathrm{mg} / \mathrm{L})\end{array}$ & $\begin{array}{c}\mathrm{UV} \\
254 \mathrm{~nm}\end{array}$ \\
\cline { 2 - 9 } & $\mathrm{AB}: 5,632$ & $\mathrm{AB}: 0,026$ & $\mathrm{AB}: 8,186$ & $\mathrm{AB}: 0,071$ & $\mathrm{AB}: 23,66$ & AB: 0,047 & AB: 4,652 & AB: 0,027 \\
\hline 5 & 10,96 & 0,067 & 5,700 & 0,116 & 25,59 & 0,143 & 7,160 & 0,179 \\
10 & 11,33 & 0,073 & 9,762 & 0,128 & 25,60 & 0,149 & 5,105 & 0,164 \\
15 & 9,434 & 0,073 & 6,908 & 0,136 & 26,16 & 0,142 & 6,208 & 0,161 \\
20 & 10,17 & 0,070 & 11,28 & 0,125 & 26,02 & 0,140 & 6,200 & 0,177 \\
\hline
\end{tabular}

AB: água bruta

Tabela 5.4 - Análises de COD e Abs UV-254 nm para desinfecção com cloro (água cor elevada).

\begin{tabular}{|c|c|c|c|c|c|c|c|c|}
\hline \multirow{3}{*}{$\begin{array}{c}\mathrm{T} \\
(\mathrm{min})\end{array}$} & \multicolumn{2}{|c|}{$\mathrm{Cl}_{2}: 2 \mathrm{mg} / \mathrm{L}$} & \multicolumn{2}{|c|}{$\mathrm{Cl}_{2}: 3 \mathrm{mg} / \mathrm{L}$} & \multicolumn{2}{|c|}{$\mathrm{Cl}_{2}: 4 \mathrm{mg} / \mathrm{L}$} & \multicolumn{2}{|c|}{$\mathrm{Cl}_{2}: 5 \mathrm{mg} / \mathrm{L}$} \\
\hline & $\begin{array}{c}\text { COD } \\
(\mathrm{mg} / \mathrm{L})\end{array}$ & $\begin{array}{c}\mathrm{UV} \\
254 \mathrm{~nm}\end{array}$ & $\begin{array}{c}\text { COD } \\
(\mathrm{mg} / \mathrm{L})\end{array}$ & $\begin{array}{c}\mathrm{UV} \\
254 \mathrm{~nm}\end{array}$ & $\begin{array}{c}\text { COD } \\
(\mathrm{mg} / \mathrm{L})\end{array}$ & $\begin{array}{c}\mathrm{UV} \\
254 \mathrm{~nm}\end{array}$ & $\begin{array}{c}\text { COD } \\
(\mathrm{mg} / \mathrm{L})\end{array}$ & $\begin{array}{c}\text { UV } \\
254 \mathrm{~nm}\end{array}$ \\
\hline & AB: 32,31 & AB: 0,123 & AB: 28,68 & AB: 0,245 & AB: 31,23 & AB: 0,248 & AB: 28,38 & AB: 0,257 \\
\hline 5 & 30,25 & 0,174 & 33,53 & 0,304 & 32,43 & 0,294 & 30,20 & 0,344 \\
\hline 10 & 27,09 & 0,195 & 35,05 & 0,305 & 35,02 & 0,302 & 30,04 & 0,346 \\
\hline 15 & 29,91 & 0,225 & 25,73 & 0,290 & 26,73 & 0,295 & 28,48 & 0,355 \\
\hline 20 & 30,07 & 0,240 & 29,88 & 0,293 & 30,02 & 0,297 & 28,74 & 0,344 \\
\hline
\end{tabular}

AB: água bruta

Os elevados valores de COD para a água bruta devem-se à matéria orgânica proveniente dos meios de cultura e substância húmica adicionadas à água de estudo.

A água de estudo com cor elevada $(\approx 100 \mathrm{uH})$ apresentou valores de COD ainda mais elevados em comparação aos da água com cor baixa $(\approx 5 \mathrm{uH})$, denotando que, além da matéria orgânica proveniente dos meios de cultura, a parcela referente à substância húmica também foi significativa para o aumento do conteúdo de carbono na água de estudo. 
Verificou-se aumento nas concentrações de COD e absorbância UV-254 $\mathrm{nm}$ após aplicação do cloro. Observou-se que os valores de UV-254 nm seguiram proporcionalmente os de COD.

O aumento do COD e da absorbância UV-254 nm para os ensaios com cloro foi atribuído às características da matéria orgânica presentes na água de estudo, além da especulação de que a oxidação do material particulado promoveu diminuição do tamanho das partículas fazendo com que as mesmas passassem pelas membranas filtrantes. Desse modo, o carbono foi mais facilmente detectado pelas análises de COD.

Também, o cloro pode ter reagido com a matéria orgânica produzindo subprodutos que contêm carbono em sua composição, sendo os mesmos detectados pelas análises de COD.

Reconhecidamente, é grande a importância das análises de quantificação de matéria orgânica no tratamento de águas, seja na otimização dos processos de tratamento, tendo em vista remoção de cor, eficiência dos processos de coagulação/floculação além do monitoramento dos compostos orgânicos precursores da formação de subprodutos da desinfecção (FERREIRA FILHO, 2001).

Segundo FERREIRA FILHO (2001) 'com relação à formação de compostos orgânicos halogenados, subprodutos da desinfecção, os resultados de COT e UV$254 \mathrm{~nm}$ devem ser analisados, preferencialmente, de forma conjunta. Isto porquê a análise de COT fornece qual a concentração total de carbono contido na amostra, não fazendo distinção com relação à natureza dos compostos orgânicos, bem como qual seu grau de reatividade com os agentes oxidantes $e$ desinfetantes aplicados ao processo de tratamento de água. Embora alguns compostos orgânicos possam ser quantificados na análise de COT como, por exemplo, os alcanos, álcoois, carboidratos e aminoácidos, os mesmos não apresentam valores de UV-254 $\mathrm{nm}$ pelo fato de não possuírem grupos cromóforos capazes de absorverem radiação ultravioleta'.

Ainda, segundo o mesmo autor, 'como a formação de trihalometanos e ácidos haloacéticos ocorre preferencialmente através de reações de oxidação e substituição do cloro com compostos orgânicos que apresentam alto grau de 
aromaticidade e instauração que, por sua vez, são capazes de absorverem radiação ultravioleta, determinada água bruta com baixa concentração de COT mas, alto valor de UV-254 nm pode apresentar grande potencial de formação de compostos orgânicos subprodutos da desinfecção, ainda que apresente um baixo valor de COT. O inverso também pode ocorrer, ou seja, água com alto valor de COT pode apresentar baixa formação potencial de subprodutos da desinfecção, uma vez que os mesmos sejam de cadeia simples, com baixo grau de aromaticidade, grau de insaturação e densidade de grupos funcionais fenólicos'.

Segundo SINGER et al. (1999), foi reportado por vários grupos de investigadores que a formação de subprodutos halogenados da desinfecção, resultado da cloração de água de abastecimento, é diretamente proporcional ao conteúdo de carbono aromático dos constituintes orgânicos. Devido às substâncias húmicas possuírem maior conteúdo de carbono aromático do que substâncias não húmicas, as primeiras são predominantes para a formação de subprodutos, assim, o controle dos mesmos, está diretamente relacionado com a remoção das substâncias húmicas antes da adição do cloro. A absorbância específica em $254 \mathrm{~nm}$ serve como parâmetro para avaliar o conteúdo de carbono aromático dos constituintes orgânicos.

CHANG et al. (1998) comentam que alguns compostos comumente encontrados na água, tais como, lignina, tanino, substâncias húmicas e vários compostos aromáticos, absorvem fortemente a radiação ultravioleta, sendo que existe grande correlação entre absorção UV, conteúdo de carbono orgânico, cor, precursores de trihalometanos e outros subprodutos da desinfecção. O consumo de cloro pode ser razoável indicador da formação de subprodutos. Então, a dose de cloro, o tempo de contato, TOC e UV-254 nm devem ter impacto significativo para o desenvolvimento de modelos estatísticos de estimativa de THMs. 


\subsection{4 - Ensaio com cloro para água de estudo isenta dos meios de cultura}

Para examinar a eficácia bactericida de desinfetantes são comumente realizados estudos de inativação em que são usadas suspensões de bactérias com alta densidade celular. Esses experimentos objetivam simplificar a interpretação de resultados experimentais, pois permitem obter especificamente a inativação de microrganismos sob condições estritamente controladas de laboratório, sem a interferência das complexas condições ambientais associadas às águas naturais e residuárias. Sob essas condições, o comportamento dose-resposta pode ser estabelecido para o par microrganismodesinfetante como função exata da dosagem do desinfetante e do tempo de exposição.

$\mathrm{Na}$ maioria dos experimentos desse tipo, culturas puras de bactérias, provenientes de culturas estoques, são inoculadas em meios específicos de crescimento, sob determinadas condições de incubação. As células são então separadas por centrifugação (por exemplo) de seus meios de crescimento e em seguida re-suspensas em solução isenta de matéria orgânica e nutrientes. Dizse que as suspensões bacterianas foram "lavadas". Assim, o material orgânico dos meios de crescimento que interferem e/ou interagem com os desinfetantes, são separados dos organismos de interesse, facilitando as análises de interação organismo/desinfetante.

Apesar de SHANG \& BLATCHLEY (2000) afirmarem que, a água de estudo inoculada com as suspensões de bactérias "lavadas", contendo, porém, alta concentração de células, ainda exerce elevada demanda de cloro, pois, as células bacterianas também são fonte de compostos orgânicos / nitrogenados.

A partir do exposto e da observação do elevado consumo de cloro que a água de estudo com os meios de cultura exerceu nessa pesquisa, pretendeu-se realizar os experimentos de desinfecção posteriores com a água de estudo sem os meios de cultura.

Foi realizado ensaio de desinfecção com cloro para a água de estudo sem os meios de cultura. O procedimento de separação das células dos meios de cultura, ou de "lavagem" das suspensões de microrganismos, encontra-se 
descrito no Capítulo 4. Empregou-se dosagens aplicadas de cloro de 2,0 e 5,0 $\mathrm{mg} / \mathrm{L}$ e tempo de contato de 20 minutos.

Para esse experimento a água de estudo foi preparada com cor baixa (3 $\mathrm{uH}$ ). As demais características físico-químicas da água estão apresentadas na tabela A-9 (Anexo).

Os resultados de inativação de E. coli, colifagos e C. perfringens estão apresentados na Tabela 5.5 .

Tabela 5.5 - Inativação de $E$. coli, colifagos e C. perfringens em função do tempo de contato e concentração residual de cloro livre para água de estudo.

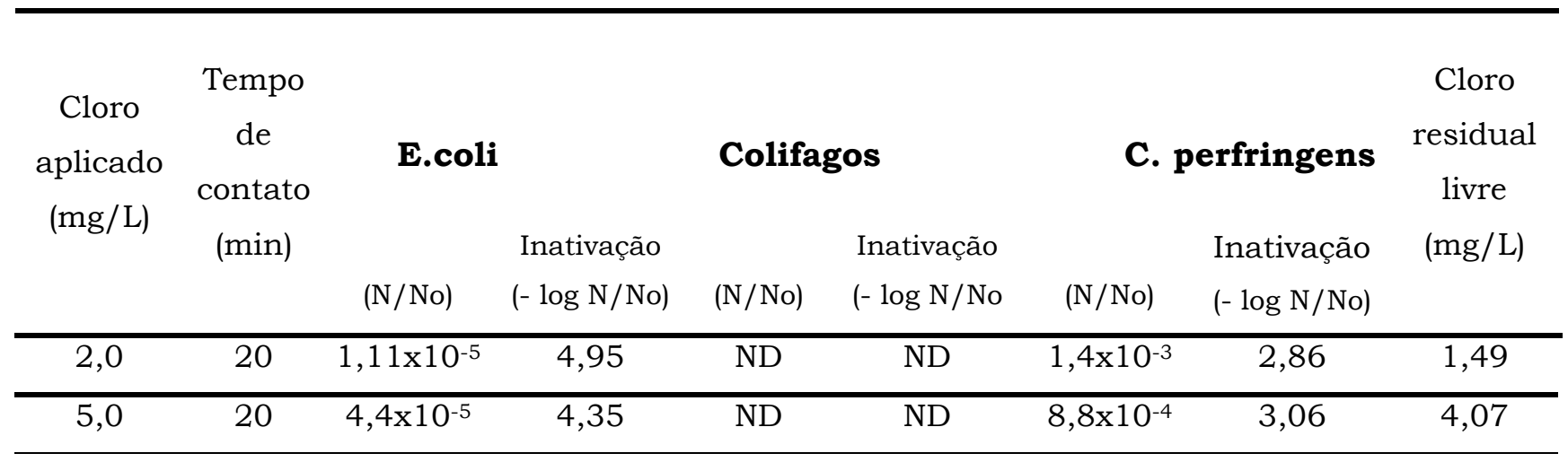

Inativação: $-\log (\mathrm{N} / \mathrm{No})$; $\mathrm{N}$ : número de microorganismos no instante t; No: número de microrganismos no instante $\mathrm{t}=0$.

ND: não detectado.

De fato, verificou-se que, inativações mais elevadas de E. coli e $C$. perfringens foram alcançadas para a água de estudo sem os meios de cultura, em relação à água de estudo com os meios de cultura, para as mesmas dosagens de cloro aplicadas e tempos de contato.

Além de ter sido consideravelmente reduzido o consumo do cloro aplicado, é interessante notar que, para esse ensaio, o cloro residual detectado foi cloro livre, e, em valores elevados. Aliás, atribuiu-se ao cloro residual livre as inativações mais elevadas obtidas, visto que é sob essa forma, que o cloro é mais efetivo para a desinfecção.

Enquanto que, nos ensaios de desinfecção para água de estudo com os meios de cultura, todo o cloro aplicado era rapidamente transformado em cloro 
combinado, para a água de estudo isenta dos meios de cultura, a demanda de cloro foi consideravelmente menor.

Entretanto, os colifagos, empregados como indicadores de vírus, não foram detectados nos experimentos em que se empregou a água de estudo sem os meios de cultura. Nesse caso, a sigla ND (não detectado) não se refere ao fato de os fagos terem sido 100\% inativados como já ocorreu anteriormente, e sim pela ausência dos mesmos na água bruta de estudo. Vale ressaltar que para todos ensaios de desinfecção as amostras eram coletadas em duplicata e os resultados ora apresentados compreendem sua média, admitindo-se, portanto que, a ausência dos fagos na água de estudo sem os meios de cultura, não foi devido a possiveis falhas inerentes aos procedimentos dos exames microbiológicos.

Os virus são agentes infecciosos muito pequenos, e, não são células (BLACK,1999), dessa forma, o procedimento de separação das células dos meios de cultura, e re-suspensão em solução livre de nutrientes, típico das suspensões bacterianas, não foi possivel para os colifagos.

Embora tenham sido realizadas algumas tentativas, após a centrifugação das suspensões que continham os colifagos não se formava o "pellet", característico das suspensões que contém células, no fundo do tubo de ensaio.

Como a proposta da pesquisa era examinar a efetividade dos desinfetantes para a inativação dos três indicadores, E. coli, colifagos e $C$. perfringens conjuntamente (adicionados na mesma água de estudo) para todos os ensaios de desinfecção, e como não foi possível a retirada do meio de cultura dos fagos, optou-se por trabalhar com todos os microrganismos em seus respectivos meios de cultura.

$\mathrm{Na}$ Tabela 5.6 estão apresentados os resultados das análises de COD e UV-254 nm para a água de estudo preparada sem os meios de cultura, tanto da água bruta como da água desinfetada com cloro nas dosagens de 2,0 e 5,0 $\mathrm{mg} / \mathrm{L}$ e tempo de contato de 20 minutos. 
Tabela 5.6 - Análises de COD e Abs UV-254 nm para desinfecção com cloro e água isenta dos meios de cultura.

\begin{tabular}{c|c|c|c|c|}
\hline \multirow{2}{*}{$\mathrm{T}(\min )$} & \multicolumn{2}{|c|}{$\mathrm{Cl}_{2}: 2 \mathrm{mg} / \mathrm{L}$} & \multicolumn{2}{c|}{$\mathrm{Cl}_{2}: 5 \mathrm{mg} / \mathrm{L}$} \\
\cline { 2 - 5 } & $\mathrm{COD}(\mathrm{mg} / \mathrm{L})$ & $\begin{array}{c}\mathrm{UV} \\
254 \mathrm{~nm}\end{array}$ & $\begin{array}{c}\mathrm{COD} \\
(\mathrm{mg} / \mathrm{L})\end{array}$ & $\begin{array}{c}\mathrm{UV} \\
254 \mathrm{~nm}\end{array}$ \\
\cline { 2 - 5 } & $\mathrm{AB}: 3,248$ & $\mathrm{AB}: 0,009$ & $\mathrm{AB}: 3,248$ & $\mathrm{AB}: 0,009$ \\
\hline 20 & 4,892 & 0,006 & 4,313 & 0,008 \\
\hline
\end{tabular}

Nota-se a diminuição do conteúdo orgânico da água, representado pelos valores mais baixos de COD e de UV-254 nm, em relação à água de estudo contendo os meios de cultura.

Os valores de COD e de UV-254 nm aumentaram após a desinfecção com cloro conforme observado nos ensaios anteriores.

Admite-se que a condição primordial para validação de estudos sob condições de laboratório é que os experimentos tenham reprodutibilidade e os resultados possam ser verificados. Em experimentos de desinfecção, para que tal ocorra, segundo a literatura, alguns requisitos devem ser satisfeitos:

- os microrganismos devem ser cultivados sob condições definidas, e, antes de serem empregados nos experimentos de desinfecção devem ser 'lavados' e homogeneamente distribuídos na água de estudo.

- no procedimento de lavagem, todas as substâncias que podem reagir com os desinfetantes (nutrientes e matéria orgânica presentes nos meios de cultura) devem ser removidas.

- para se obter a distribuição homogênea dos microrganismos-teste na suspensão, todos os agregados devem ser eliminados. 
- ainda, o desinfetante deve ser homogeneamente distribuído, o que requer mistura ótima da água. Se esses requisitos não forem satisfeitos a reprodutibilidade dos resultados torna-se prejudicada.

Entretanto, as condições encontradas na prática são completamente diferentes.

Em relação a essa discussão SCHOENEN (2002) apresenta os seguintes argumentos:

"A transmissão feco-oral dos patógenos pela água não segue qualquer regra pré - definida. Assim, não se pode esperar que os patogênicos estejam em suspensão na água como células individuais e que a água natural esteja isenta de substâncias interferentes aos desinfetantes. Admite-se que os microrganismos sejam transportados por particulas e circundados por substâncias protetoras, e que essas particulas protegem os microrganismos da ação dos desinfetantes. A água pode conter inúmeras substâncias que reagem com os desinfetantes quimicos. Ainda, a intensa mistura requerida nos ensaios de laboratório, pode ser algo difícil de ser alcançado na prática".

\subsection{5 - Monitoramento de THMs na água de estudo após desinfecção com cloro}

A produção de clorofórmio, bromodiclorometano, dibromoclorometano e bromofórmio foi monitorada para a água de estudo com cor elevada após a cloração.

O monitoramento de THMs foi realizado paralelamente aos exames microbiológicos e análises físico-químicas realizadas após os ensaios de desinfecção com cloro. Assim, as concentrações aplicadas de cloro foram as mesmas usadas anteriormente: 2,$0 ; 3,0 ; 4,0$ e 5,0 mg/L.

Entretanto, a água de estudo escolhida para monitoramento dos THMs foi somente a água com cor elevada, em virtude da maior quantidade de substância húmica adicionada. 
Os tempos de contato definidos para realização das análises de THMs foram de 20 minutos (tempo máximo empregado nos ensaios de inativação dos microrganismos) 24 horas, 6, 12 e 30 dias.

As características da água de estudo bruta, bem como os resultados das análises físico-químicas antes e após a cloração estão apresentados nas Tabelas A5 a A8 em anexo.

Os THMs foram determinados por cromatografia gasosa com detector de captura de elétrons.

Como resultado da análise dos cromatogramas gerados foi construída a Figura 5.17.

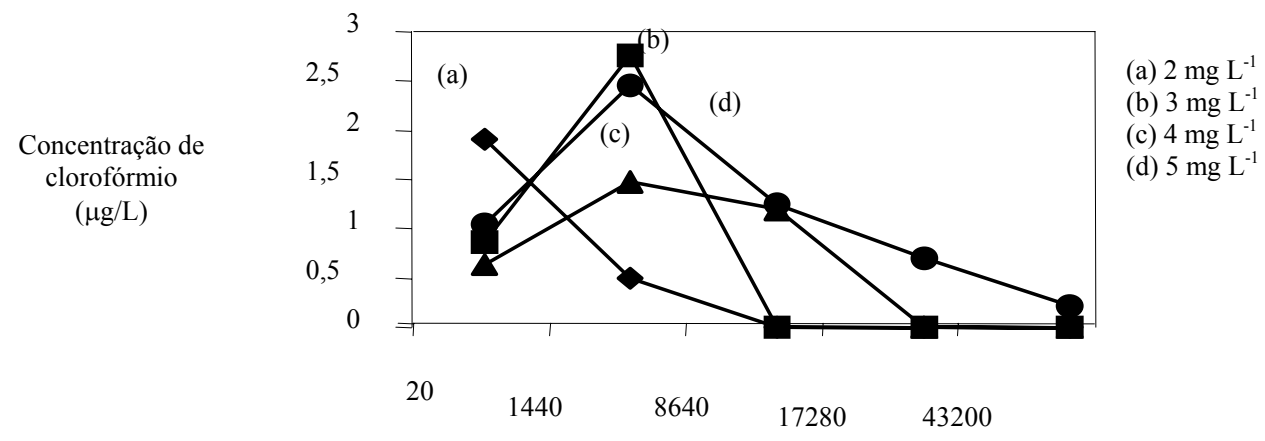

Tempo de incubação (min)

Figura 5.17 - Variação da concentração de clorofórmio para as concentrações de cloro aplicadas de 2,0; 3,0; 4,0 e 5,0 mg/L.

Observou-se que, o triclorometano ou o clorofórmio foi o composto predominantemente detectado nas amostras de água clorada, enquanto que as outras três espécies de THM monitoradas não foram detectadas. Esse fato foi atribuído à ausência de compostos brominados presentes na água.

Para a concentração de $2,0 \mathrm{mg} / \mathrm{L}$ de cloro aplicado ocorreu rápida formação inicial de clorofórmio, ou seja, para essa dosagem a detecção da concentração de clorofórmio mais elevada ocorreu para o tempo de contato de 20 minutos, após esse tempo, esse valor diminuiu até tender a zero. Este efeito 
presumivelmente foi associado com a perda do clorofórmio por evaporação ou formação de outros subprodutos da desinfecção com cloro.

Para as demais dosagens de cloro aplicados - 3,0; 4,0 e 5,0 mg/L - a concentração máxima de clorofórmio foi alcançada após o período de incubação de 24 horas (1440 minutos).

Observou-se ainda que, a máxima concentração de clorofórmio detectada foi de $2,7 \mu \mathrm{g} \mathrm{\textrm {L } ^ { - 1 }}$.

De maneira geral, constatou-se que o aumento da concentração de clorofórmio apresentou relação com o aumentou da concentração de cloro, e sua concentração aumentou no decorrer do tempo, de 1 a 6 dias, sendo que, após esse tempo diminuiu até tender a zero, no trigésimo dia.

O monitoraramento da formação de THMs em águas cloradas geralmente são realizados durante intervalo de tempo de 24 horas (MUTTAMARA et al., 1995). Após esse tempo existe pouca informação na literatura concernente aos THMs gerados.

A formação de THMs em condições naturais não é instantânea. Em algumas circunstâncias a formação dos mesmos pode completar-se em menos de uma hora, em outras, é possivel que se exijam vários dias antes que ocorra a máxima produção de THMs.

A reação é mais rápida quando se eleva a temperatura e o $\mathrm{pH}$, e em presença de brometos. Assim, grande parte dos THMs com possibilidade de chegar ao consumidor são produzidos no sistema de distribuição de água, onde o contato do cloro livre com os precursores ocorre por um longo período de tempo (ZARPELON \& RODRIGUES, 2002). 


\section{2 - Desinfecção com ácido peracético}

Nos ensaios de desinfecção com ácido peracético estudou-se o efeito das concentrações aplicadas de 2,0;3,0;4,0 e 5,0 mg/L de ácido peracético e tempos de contato de 5, 10, 15 e 20 minutos na inativação de $E$. coli, colifagos e C. perfringens.

Foram empregadas duas águas de estudo: com cor baixa (aproximadamente $5 \mathrm{uH}$ ) e com cor elevada (aproximadamente $100 \mathrm{uH}$ ).

Além dos exames microbiológicos de E. coli, colifagos e C. perfringens, foram avaliados e monitorados os seguintes parâmetros físico-químicos da água de estudo: pH, temperatura, alcalinidade, COD, Abs $254 \mathrm{~nm}$ e concentração residual de ácido peracético.

Todos os resultados referentes ao No - número inicial de microrganismos adicionados à água bruta e $\mathrm{N}$ - número final de microrganismos, bem como o monitoramento das análises físico-químicas realizadas, referentes aos ensaios de desinfecção com ácido peracético estão apresentados no Anexo nas Tabelas A10 - A13 (para a água de estudo com cor baixa) e A14-A17 (para água de estudo com cor elevada).

Entretanto, conforme o desencadeamento da discussão alguns dos resultados são sumarizados e apresentados no corrente texto.

\subsection{1 - Inativação de E. coli, colifagos e C. perfringens com ácido peracético}

Os resultados de inativação de $E$. coli, colifagos e $C$. perfringens com ácido peracético para água de estudo com cor baixa estão apresentados na Tabela 5.7 e para água de estudo com cor elevada na Tabela 5.8. 
Tabela 5.7 - Inativação de E. coli, colifagos e C. perfringens em função do tempo de contato e concentração residual de ácido peracético para água de estudo com cor baixa.

\begin{tabular}{|c|c|c|c|c|c|c|c|c|}
\hline \multirow{2}{*}{$\begin{array}{c}\text { Ácido } \\
\text { peracético } \\
\text { aplicado } \\
(\mathrm{mg} / \mathrm{L})\end{array}$} & \multirow{2}{*}{$\begin{array}{l}\text { Tempo } \\
\text { de } \\
\text { contato } \\
\text { (min) }\end{array}$} & \multirow{2}{*}{$\begin{array}{l}\text { E. coli } \\
\qquad(\mathrm{N} / \mathrm{No})\end{array}$} & \multirow{2}{*}{ Inativação } & \multicolumn{2}{|l|}{ Colifagos } & \multicolumn{2}{|c|}{ C. perfringens } & \multirow{2}{*}{$\begin{array}{c}\text { Ácido } \\
\text { peracético } \\
\text { residual } \\
(\mathrm{mg} / \mathrm{L})\end{array}$} \\
\hline & & & & (N/No) & Matrvaçao & (N/No) & Inativaçao & \\
\hline \multirow{4}{*}{2,0} & 5 & $5,0 \times 10^{-4}$ & 3,30 & $2,6 \times 10^{-1}$ & 0,59 & $1,3 \times 10^{-2}$ & 1,88 & 1,28 \\
\hline & 10 & $1,3 \times 10^{-4}$ & 3,90 & $2,0 \times 10^{-1}$ & 0,70 & $6,7 \times 10^{-3}$ & 2,18 & 1,26 \\
\hline & 15 & $1,5 \times 10^{-5}$ & 4,82 & $1,0 \times 10^{-1}$ & 1,00 & $6,7 \times 10^{-3}$ & 2,18 & 1,18 \\
\hline & 20 & $1,0 \times 10^{-5}$ & 5,00 & $2,0 \times 10^{-2}$ & 1,70 & $6,7 \times 10^{-3}$ & 2,18 & 1,03 \\
\hline \multirow{4}{*}{3,0} & 5 & $4,0 \times 10^{-3}$ & 2,40 & $1,1 \times 10^{-1}$ & 0,95 & $\overline{1,00}$ & 0,00 & 2,28 \\
\hline & 10 & $4,0 \times 10^{-3}$ & 2,40 & $8,0 \times 10^{-2}$ & 1,08 & $3,1 \times 10^{-1}$ & 0,51 & 1,96 \\
\hline & 15 & $2,0 \times 10^{-4}$ & 3,70 & $6,0 \times 10^{-2}$ & 1,22 & $1,5 \times 10^{-1}$ & 0,81 & 1,87 \\
\hline & 20 & $2,0 \times 10^{-4}$ & 3,70 & $5,0 \times 10^{-2}$ & 1,33 & $1,5 \times 10^{-1}$ & 0,81 & 1,74 \\
\hline \multirow{4}{*}{4,0} & 5 & $3,5 \times 10^{-4}$ & 3,46 & $2,5 \times 10^{-2}$ & 1,60 & $3,7 \times 10^{-1}$ & 0,43 & 2,65 \\
\hline & 10 & $4,0 \times 10^{-4}$ & 3,40 & $2,0 \times 10^{-2}$ & 1,70 & $7,3 \times 10^{-2}$ & 1,13 & 2,47 \\
\hline & 15 & $4,2 \times 10^{-5}$ & 4,38 & $1,4 \times 10^{-2}$ & 1,85 & $1,0 \times 10^{-1}$ & 1,00 & 2,43 \\
\hline & 20 & $3,2 \times 10^{-5}$ & 4,49 & $1,0 \times 10^{-2}$ & 2,00 & $1,7 \times 10^{-1}$ & 0,78 & 2,42 \\
\hline \multirow{4}{*}{5,0} & 5 & $3,0 \times 10^{-4}$ & 3,52 & $3,0 \times 10^{-1}$ & 0,52 & $3,0 \times 10^{-1}$ & 0,52 & 3,27 \\
\hline & 10 & $9,0 \times 10^{-5}$ & 4,05 & $1,0 \times 10^{-1}$ & 1,00 & $5,0 \times 10^{-2}$ & 1,30 & 3,14 \\
\hline & 15 & $7,0 \times 10^{-5}$ & 4,15 & $5,0 \times 10^{-2}$ & 1,30 & $2,7 \times 10^{-2}$ & 1,57 & 2,80 \\
\hline & 20 & $1,0 \times 10^{-5}$ & 5,00 & $3,0 \times 10^{-2}$ & 1,52 & $3,3 \times 10^{-2}$ & 1,48 & 2,73 \\
\hline
\end{tabular}

Inativação: - $\log (\mathrm{N} / \mathrm{No})$; $\mathrm{N}$ : número de microorganismos no instante $\mathrm{t}$; No: número de microrganismos no instante $\mathrm{t}=0$. 
Tabela 5.8 - Inativação de E. coli, colifagos e C. perfringens em função do tempo de contato e concentração residual de ácido peracético para água de estudo com cor elevada.

\begin{tabular}{|c|c|c|c|c|c|c|c|c|}
\hline $\begin{array}{c}\text { Ácido } \\
\text { peracético } \\
\text { aplicado } \\
(\mathrm{mg} / \mathrm{L})\end{array}$ & $\begin{array}{l}\text { Tempo } \\
\text { de } \\
\text { contato } \\
\text { (min) }\end{array}$ & E. coli & Inativação & Colifagos & Inativação & C. perfring & Inativação & $\begin{array}{c}\text { Ácido } \\
\text { peracético } \\
\text { residual } \\
(\mathrm{mg} / \mathrm{L})\end{array}$ \\
\hline \multirow{4}{*}{2,0} & 5 & $3,5 \times 10^{-2}$ & 1,45 & $2,3 \times 10^{-1}$ & 0,64 & $4,5 \times 10^{-1}$ & 0,34 & 1,11 \\
\hline & 10 & $2,3 \times 10^{-4}$ & 3,65 & $2,3 \times 10^{-1}$ & 1,64 & $2,0 \times 10^{-2}$ & 1,70 & 0,70 \\
\hline & 15 & $5,0 \times 10^{-6}$ & 5,30 & $1,0 \times 10^{-2}$ & 2,00 & $8,0 \times 10^{-2}$ & 1,09 & 0,66 \\
\hline & 20 & $5,0 \times 10^{-6}$ & 5,30 & $2,5 \times 10^{-3}$ & 2,60 & $4,5 \times 10^{-2}$ & 1,34 & 0,47 \\
\hline \multirow{4}{*}{3,0} & 5 & $3,8 \times 10^{-4}$ & 3,42 & $6,9 \times 10^{-2}$ & 1,16 & $2,8 \times 10^{-1}$ & 0,55 & 1,55 \\
\hline & 10 & $1,9 \times 10^{-4}$ & 3,72 & $9,0 \times 10^{-3}$ & 2,04 & $2,8 \times 10^{-1}$ & 0,55 & 1,18 \\
\hline & 15 & $6,3 \times 10^{-5}$ & 4,20 & $1,3 \times 10^{-3}$ & 2,88 & $5,0 \times 10^{-2}$ & 1,30 & 1,05 \\
\hline & 20 & $6,3 \times 10^{-6}$ & 5,20 & $4,0 \times 10^{-4}$ & 3,39 & $2,5 \times 10^{-2}$ & 1,60 & 1,06 \\
\hline \multirow{4}{*}{4,0} & 5 & $3,0 \times 10^{-5}$ & 4,52 & $5,0 \times 10^{-2}$ & 1,30 & $1,6 \times 10^{-1}$ & 0,79 & 2,10 \\
\hline & 10 & $1,0 \times 10^{-5}$ & 5,00 & $3,0 \times 10^{-2}$ & 1,52 & $8,0 \times 10^{-2}$ & 1,09 & 2,27 \\
\hline & 15 & $2,0 \times 10^{-6}$ & 5,69 & $3,0 \times 10^{-2}$ & 1,52 & $8,0 \times 10^{-2}$ & 1,09 & 2,36 \\
\hline & 20 & $1,0 \times 10^{-6}$ & 6,00 & $5,0 \times 10^{-3}$ & 2,30 & $4,0 \times 10^{-2}$ & 1,39 & 2,20 \\
\hline \multirow{4}{*}{5,0} & 5 & $5,0 \times 10^{-6}$ & 5,30 & $2,5 \times 10^{-3}$ & 2,60 & $6,2 \times 10^{-3}$ & 2,21 & 2,80 \\
\hline & 10 & $4,0 \times 10^{-6}$ & 5,40 & $5,5 \times 10^{-4}$ & 3,25 & $7,7 \times 10^{-5}$ & 4,11 & 2,74 \\
\hline & 15 & $1,0 \times 10^{-6}$ & 6,00 & $2,0 \times 10^{-4}$ & 3,70 & $7,7 \times 10^{-5}$ & 4,11 & 2,52 \\
\hline & 20 & $1,0 \times 10^{-6}$ & 6,00 & $1,0 \times 10^{-5}$ & 5,00 & $7,7 \times 10^{-5}$ & 4,11 & 2,37 \\
\hline
\end{tabular}

Inativação: - $\log (\mathrm{N} / \mathrm{No})$; N: número de microorganismos no instante t; No: número de microrganismos no instante $t=0$.

Com os resultados de inativação dos microrganismos E. coli, colifagos e C. perfringens obtidos experimentalmente, foram construidas as Figuras 5.18 a 5.25 que são os gráficos de $\log \mathrm{N} / \mathrm{N}_{0}$ em função do produto C.t-concentração residual de ácido peracético $(C)$ pelo tempo de contato $(t)$. 


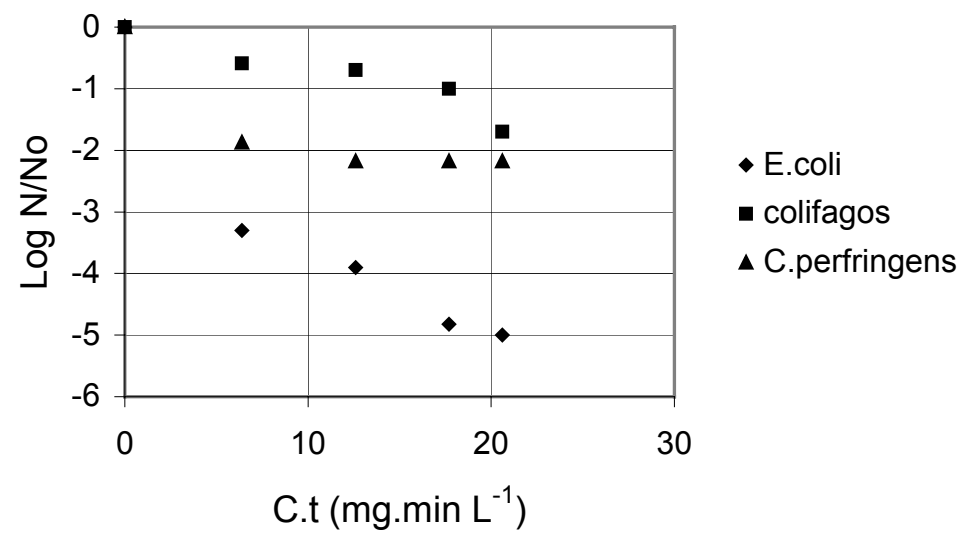

Figura 5.18- Inativação de $E$. coli, colifagos e $C$. perfringens para $2,0 \mathrm{mg} / \mathrm{L}$ de ácido peracético aplicado (cor baixa).

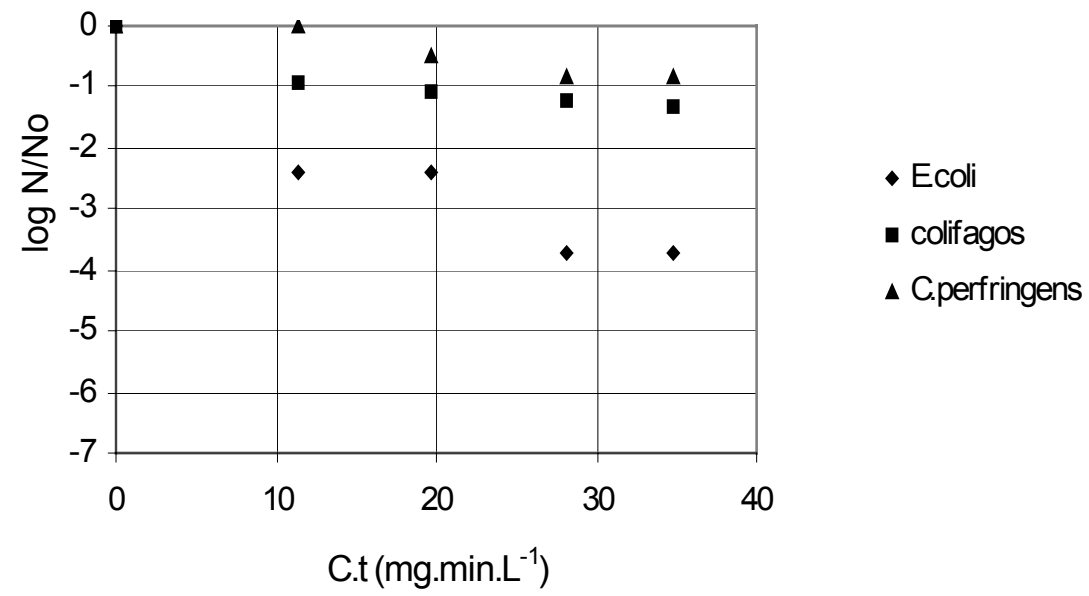

Figura 5.19- Inativação de E. coli, colifagos e C. perfringens para 3,0 mg/L de ácido peracético aplicado (cor baixa). 


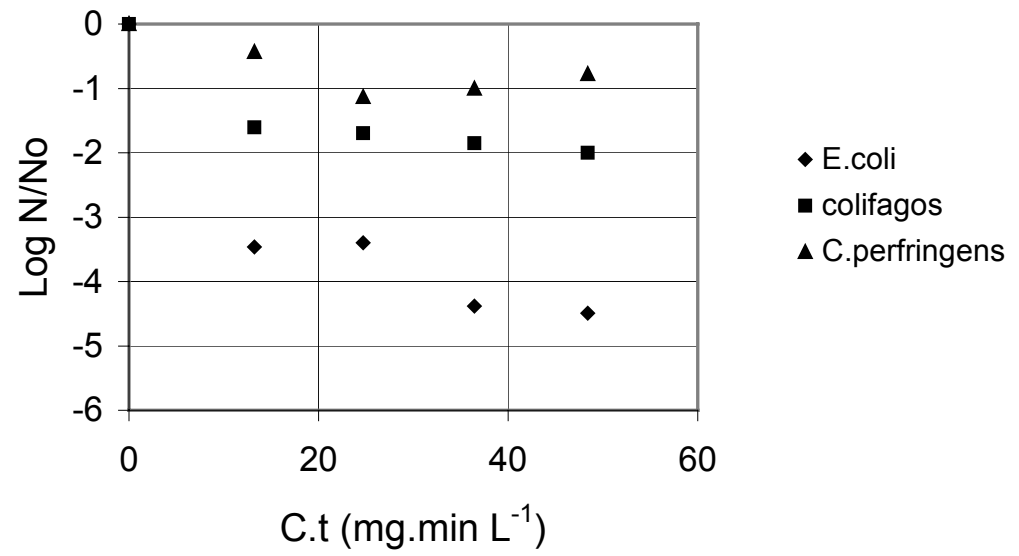

Figura 5.20- Inativação de $E$. coli, colifagos e C. perfringens para 4,0 mg/L de ácido peracético aplicado (cor baixa).

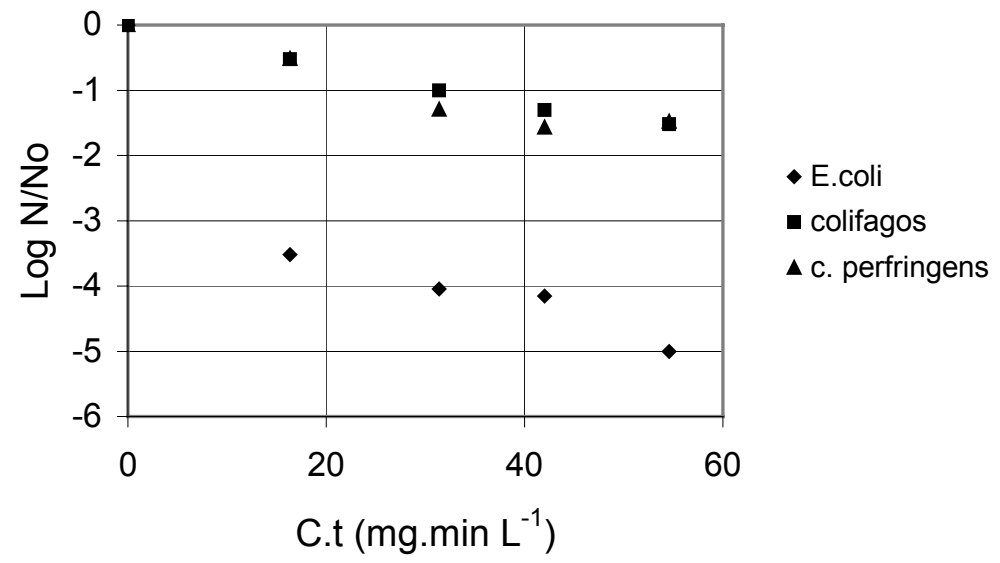

Figura 5.21- Inativação de $E$. coli, colifagos e $C$. perfringens para 5,0 mg/L de ácido peracético aplicado (cor baixa). 


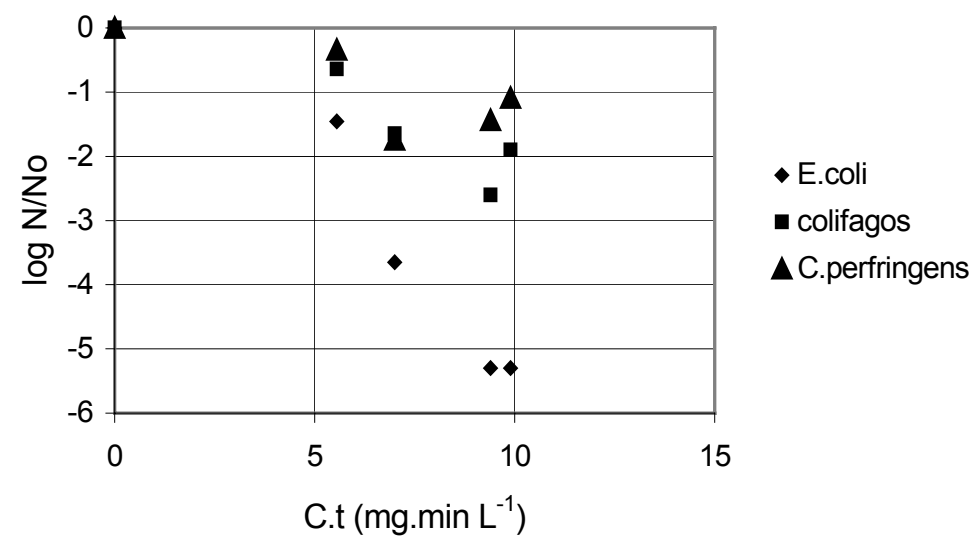

Figura 5.22- Inativação de $E$. coli, colifagos e $C$. perfringens para $2,0 \mathrm{mg} / \mathrm{L}$ de ácido peracético aplicado (cor elevada).

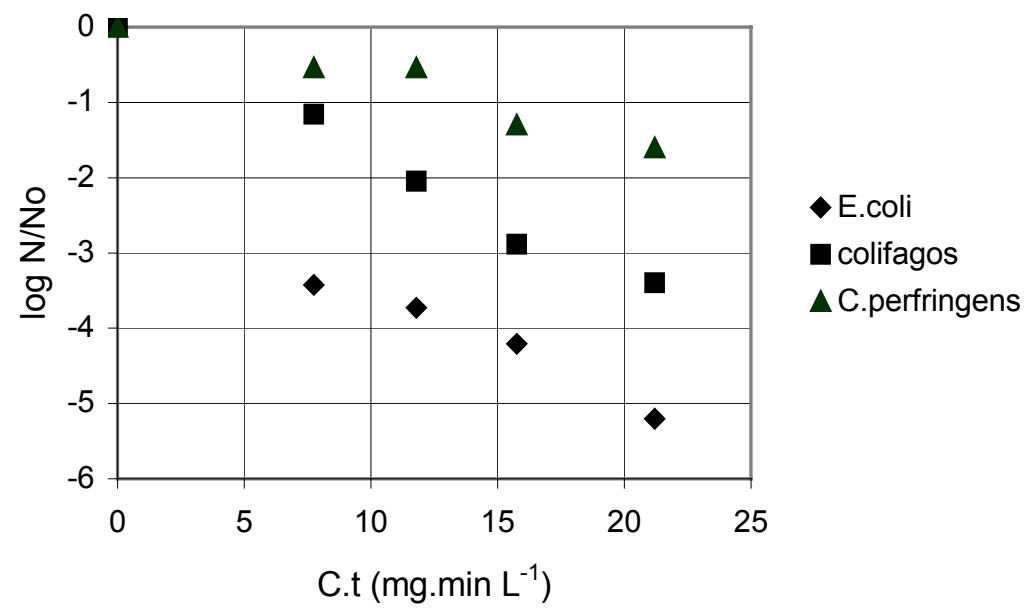

Figura 5.23- Inativação de E. coli, colifagos e C. perfringens para 3,0 mg/L de ácido peracético aplicado (cor elevada). 


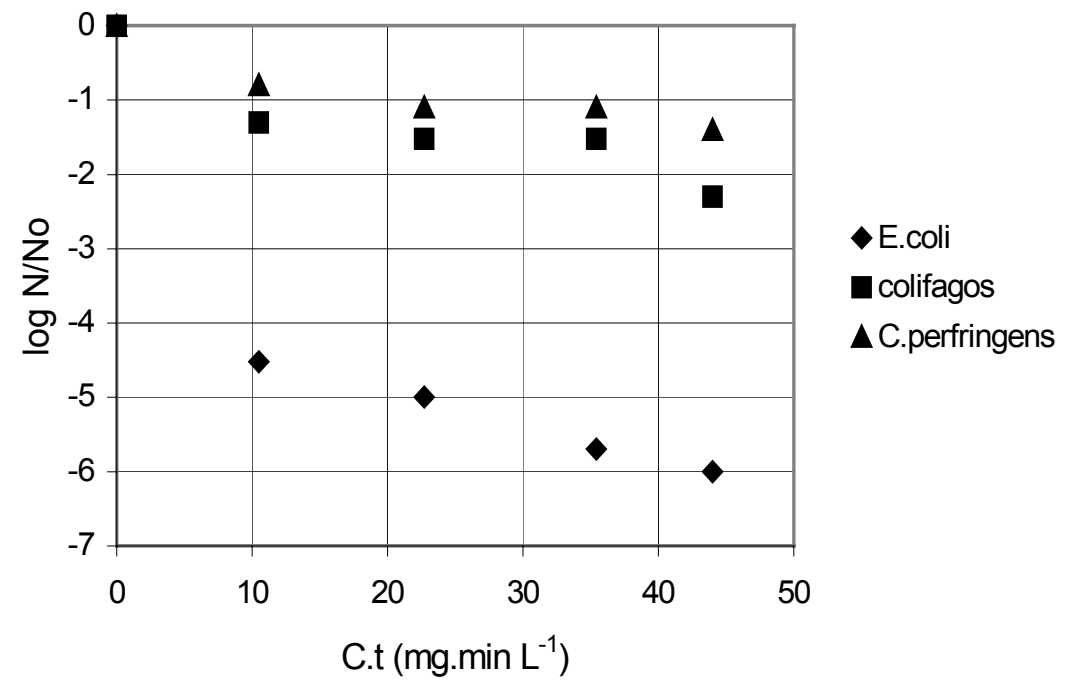

Figura 5.24- Inativação de E. coli, colifagos e C. perfringens para 4,0 mg/L de ácido peracético aplicado (cor elevada).

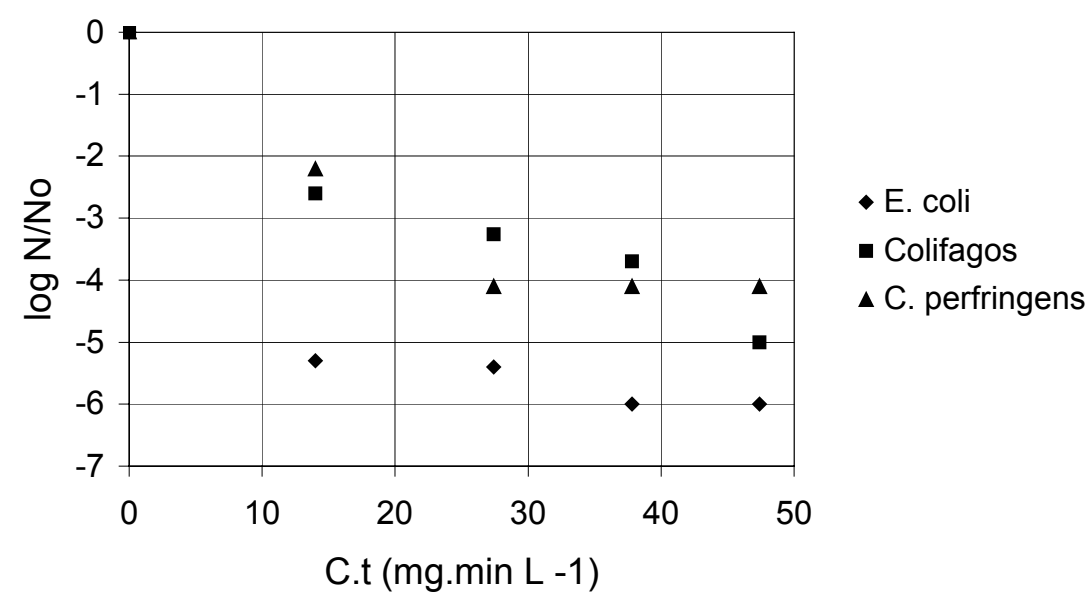

Figura 5.25- Inativação de $E$. coli, colifagos e $C$. perfringens para 5,0 mg/L de ácido peracético aplicado (cor elevada).

De maneira geral, para as duas águas de estudo, os resultados dos ensaios de desinfecção com ácido peracético indicaram efetiva inativação dos microrganismos indicadores empregados, mesmo na presença de elevada concentração de matéria orgânica. 
Para a E. coli, mesmo com a menor concentração de ácido peracético aplicado - 2,0 mg/L -, para a água de estudo com cor baixa, obteve-se 5 log de inativação para o tempo de contato de 20 minutos; e para água com cor elevada 5,30 log de inativação de E. coli para os tempos de contato de 15 e 20 minutos.

Para a dosagem aplicada de 5,0 mg/L, para a água com cor baixa, obtiveram-se inativações maiores que 4 log para os tempos de contato de $5 ; 10$ e 15 minutos, sendo que, para a água com cor elevada e mesma dosagem aplicada, inativações de E. coli da ordem de $6 \log$ foram obtidas para os tempos de contato de 15 e 20 minutos.

Os indicadores virais, colifagos, foram menos eficientemente inativados pelo ácido peracético que a bactéria $E$. coli.

Especialmente para a água com cor baixa, inativações consideradas muito baixas que variaram de 0,52 a 2 log ocorreram, mesmo para as maiores dosagens aplicadas e tempos de contato empregados.

Para água com cor elevada, dosagem de 2,0 mg/L de APA e 5 minutos de contato, apenas 0,64 log de inativação foi obtido, sendo que, para a mesma concentração e tempo de contato de 20 minutos, obteve-se 2,60 log de inativação. No entanto, para a mesma água com $5 \mathrm{mg} / \mathrm{L}$ de APA aplicado, 3,69 e 5 log foram obtidos para os tempos de contato de 15 e 20 minutos, respectivamente.

Também, a elevada resistência de C. perfringens à desinfecção com ácido peracético foi observada pelos resultados obtidos. Para a água com cor baixa, as inativações variaram de 0 a 2,18 log para as dosagens e tempos de contato empregados. Para a água com cor elevada, apenas 0,34 log de inativação foi obtida para 2,0 mg/L e 5 minutos de contato.

No entanto, para 5,0 mg/L de APA aplicado e 5 minutos de contato 2,21 $\log$ de inativação foi obtido; para essa mesma concentração e tempos de contato de 10, 15 e 20 minutos o número final de C.perfringens foi zero o que pode significar inativações maiores que $4 \mathrm{log}$. 
SARTORI (2004) desinfetou efluente de esgoto sanitário com APA e verificou que a $E$. coli foi menos resistente ao indicador viral colifagos e à bactéria $C$. perfringens.

Para o valor de Ct igual a $300 \mathrm{mg} \cdot \mathrm{min} / \mathrm{L}$, por exemplo, a inativação de $E$. coli foi de até 4 log em média, enquanto que para colifagos foi de $2 \log$ e para $C$. perfringens foi de 0,63 log. A inativação de $E$. coli esteve entre 99,6\% e 99,999\%. A inativação de colifagos ficou entre 94,2\% e 99,7\%. Verificou-se, portanto, que o APA teve maior poder bactericida (desde que a bactéria não seja esporulada) que virucida. $\mathrm{E}$, em relação à bactéria esporulada $C$. perfringens obteve-se eficiência de inativação entre 64,3\% a 96,6\%.

BALDRY \& FRENCH (1989) obtiveram que $25 \mathrm{mg} / \mathrm{L}$ de ácido peracético rapidamente inativou E.coli e $S$. faecalis resultando em inativações do número de bactérias maiores que $10^{-5}(99,999 \%)$ em 5 minutos de tempo de contato. Mesmo na presença de grande quantidade de matéria orgânica (4 g/L) proveniente do extrato de levedura do meio de cultura, 100mg/L de ácido peracético foi requerido para obter $5 \log$ de inativação das bactérias.

As concentrações efetivas de ácido peracético para inativar os bacteriófagos MS2 e $\Phi x 174$ em água desmineralisada foram de 15 e $30 \mathrm{mg} / \mathrm{L}$ respectivamente, resultando em inativações logarítmicas maiores que 4 (99,99\%) em 5 minutos de contato. Na presença de matéria orgânica, aproximadamente $100 \mathrm{mg} / \mathrm{L}$ de ácido peracético foi efetivo para inativar os bacteriófagos. Concentrações mais elevadas de ácido peracético, 750 a 1500 mg/L foram requeridas para obtenção de 99,99\% de inativação de Poliovírus em 15 minutos de tempo de contato.

GASI et al. (1995) realizaram estudo de desinfecção de efluentes de lodos ativados com ácido peracético e analisaram aspectos relativos à eficiência do processo em relação aos microrganismos: coliformes totais (CT), coliformes fecais $(\mathrm{CF})$, C.perfringens e colifagos. "Para remover 3,7 log de CF foram necessários 5,0 mg/L de aplicação de ácido peracético e tempo de contato de 27 minutos. As remoções de colifagos observadas para 27 minutos de tempo de contato foram de 94\% e 96\% para dosagens de ácido peracético de 3 e $5 \mathrm{mg} / \mathrm{L}$ respectivamente. Tal fato indica que o produto tem menor poder virucida que 
bactericida. Observou-se ainda, pequena redução da densidade de $C$. perfringens $27 \%$ para dosagem de $3 \mathrm{mg} / \mathrm{L}$ e $62 \%$ para dosagem de $5 \mathrm{mg} / \mathrm{L}$ ”.

\subsection{2 - Influência das características da água de estudo}

Fatores como concentração do desinfetante, tempo de contato, $\mathrm{pH}$, temperatura, alcalinidade, presença ou não de material em suspensão e particulado na água, podem afetar a eficiência da desinfecção.

A temperatura da água de estudo foi monitorada, e esteve entre 22 e $24^{\circ} \mathrm{C}$ para todos os ensaios de desinfecção com APA.

Segundo STAMPI25 et al. (2001) apud KITIS (2003) o APA pode ser efetivo numa extensa faixa de temperatura. Entretanto, em geral, similarmente a outros desinfetantes químicos, ocorre aumento de inativação microbiana conforme seja aumentada a temperatura da água durante desinfecção com APA.

De acordo com DEGUSSA (2003), na faixa de $0^{\circ} \mathrm{C}$ a $37^{\circ} \mathrm{C}$ a eficácia do APA é quase que independente da temperatura. Praticamente não há outros desinfetantes que sejam tão efetivos em faixas de temperatura tão amplas.

Quanto ao pH, segundo KITIS (2003), o APA é afetado pelo pH, e apresenta maior atividade em $\mathrm{pH}$ baixo.

$\mathrm{Na}$ presente pesquisa não se modificou o $\mathrm{pH}$ da água de estudo. Trabalhou-se com seu $\mathrm{pH}$ natural que variou de 6,0 a 7,6.

Após a desinfecção com APA não se observou mudança significativa nos valores de $\mathrm{pH}$ que variaram de 6,5 a 7,7.

Também, SARTORI (2004) reportou que o tratamento com APA não modificou significativamente o $\mathrm{pH}$ do efluente (variação média de 0,14 unidades de $\mathrm{pH}$ ) sendo que os valores estiveram entre 7,34 e 7,70. A autora observa ainda que outros pesquisadores obtiveram pouca ou nenhuma alteração do pH, após desinfecção com APA, mesmo ao trabalharem com dosagens elevadas de APA.

\footnotetext{
${ }^{25}$ STAMPI, S. et al. (2001). Evaluation of the efficiency of peracetic acid in the disinfection of sewage
} effluents. J. Appl. Microbiol, 91:833-8. 
Observou-se que a diferença entre cor baixa e cor elevada das duas águas estudadas não interferiu nos resultados de inativação dos microrganismos empregadas.

Um aspecto relevante apontado por BALDRY et al. (1991), também observado na presente pesquisa, foi a verificação de que a presença de matéria orgânica na forma de extrato de levedura, não afetou negativamente a eficiência do ácido peracético conforme ocorreu com o cloro.

Ao contrário do que ocorreu com o cloro, os residuais de APA foram considerados ainda elevados após os tempos de contato empregados.

A alcalinidade apresentou valores entre 83,83 e 111,77 $\mathrm{mg} \mathrm{CaCO}_{3} / \mathrm{L}$, sendo que, pela variação dos valores apresentados não foi possível concluir sobre a interferência, positiva ou negativa, dessa variável na eficiência de inativação dos microrganismos.

\subsection{2 - COD e Abs UV $254 \mathrm{~nm}$}

Os resultados das análises de COD e Abs UV - $254 \mathrm{~nm}$ para os ensaios de desinfecção com ácido peracético para as duas águas de estudo estão apresentados nas Tabelas 5.9 e 5.10 .

Tabela 5.9 - Análises de COD e Abs UV-254 nm para desinfecção com ácido peracético para água com cor baixa.

\begin{tabular}{c|c|c|c|c|c|c|c|c}
\hline \multirow{2}{*}{$\begin{array}{c}\mathrm{T} \\
(\mathrm{min})\end{array}$} & \multicolumn{2}{|c|}{ APA: $2 \mathrm{mg} / \mathrm{L}$} & \multicolumn{2}{c|}{ APA: $3 \mathrm{mg} / \mathrm{L}$} & \multicolumn{2}{c|}{ APA: $4 \mathrm{mg} / \mathrm{L}$} & \multicolumn{2}{c}{ APA: $5 \mathrm{mg} / \mathrm{L}$} \\
\cline { 2 - 9 } & $\begin{array}{c}\mathrm{COD} \\
(\mathrm{mg} / \mathrm{L})\end{array}$ & $\begin{array}{c}\mathrm{UV} \\
254 \mathrm{~nm}\end{array}$ & $\begin{array}{c}\text { COD } \\
(\mathrm{mg} / \mathrm{L})\end{array}$ & $\begin{array}{c}\text { UV } \\
254 \mathrm{~nm}\end{array}$ & $\begin{array}{c}\text { COD } \\
(\mathrm{mg} / \mathrm{L})\end{array}$ & $\begin{array}{c}\text { UV } \\
254 \mathrm{~nm}\end{array}$ & $\begin{array}{c}\text { COD } \\
(\mathrm{mg} / \mathrm{L})\end{array}$ & $\begin{array}{c}\text { UV } \\
254 \mathrm{~nm}\end{array}$ \\
\cline { 2 - 9 } & AB: 18,76 & AB: 0,072 & AB: 4,592 & AB: 0,052 & AB: 17,28 & AB: 0,054 & AB: 5,254 & AB: 0,016 \\
\hline 5 & 21,02 & 0,117 & 4,749 & 0,141 & 19,92 & 0,243 & 21,81 & 0,359 \\
10 & 19,91 & 0,142 & 4,360 & 0,248 & 20,43 & 0,289 & 29,39 & 0,300 \\
15 & 20,99 & 0,129 & 4,726 & 0,147 & 20,30 & 0,270 & 26,04 & 0,375 \\
20 & 20,25 & 0,140 & 4,362 & 0,158 & 20,12 & 0,284 & 22,49 & 0,093 \\
\hline
\end{tabular}

$\mathrm{AB}=$ água bruta 
Tabela 5.10 - Análises de COD e Abs UV-254 nm para desinfecção com ácido peracético para água com cor elevada.

\begin{tabular}{c|c|c|c|c|c|c|c|c}
\hline \multirow{2}{*}{$\begin{array}{c}\mathrm{T} \\
(\mathrm{min})\end{array}$} & \multicolumn{2}{|c|}{ APA: $2 \mathrm{mg} / \mathrm{L}$} & \multicolumn{2}{c|}{ APA: $3 \mathrm{mg} / \mathrm{L}$} & \multicolumn{2}{c|}{ APA: 4 mg/L } & \multicolumn{2}{c}{ APA: $5 \mathrm{mg} / \mathrm{L}$} \\
\cline { 2 - 9 } & $\begin{array}{c}\mathrm{COD} \\
(\mathrm{mg} / \mathrm{L})\end{array}$ & $\begin{array}{c}\mathrm{UV} \\
254 \mathrm{~nm}\end{array}$ & $\begin{array}{c}\text { COD } \\
(\mathrm{mg} / \mathrm{L})\end{array}$ & $\begin{array}{c}\text { UV } \\
254 \mathrm{~nm}\end{array}$ & $\begin{array}{c}\text { COD } \\
(\mathrm{mg} / \mathrm{L})\end{array}$ & $\begin{array}{c}\text { UV } \\
254 \mathrm{~nm}\end{array}$ & $\begin{array}{c}\mathrm{COD} \\
(\mathrm{mg} / \mathrm{L})\end{array}$ & $\begin{array}{c}\text { UV } \\
254 \mathrm{~nm}\end{array}$ \\
\cline { 2 - 9 } & AB: 30,13 & AB: 0,352 & AB: 28,68 & AB: 0,284 & AB: 15,53 & AB: 0,208 & AB: 14,53 & AB: 0,190 \\
\hline 5 & 32,08 & 0,406 & 32,05 & 0,381 & 28,63 & 0,305 & 24,03 & 0,260 \\
10 & 32,97 & 0,405 & 31,76 & 0,382 & 28,67 & 0,291 & 15,89 & 0,225 \\
15 & 32,28 & 0,414 & 30,47 & 0,429 & 27,19 & 0,293 & 25,24 & 0,266 \\
20 & 32,78 & 0,400 & 31,15 & 0,378 & 18,76 & 0,298 & 25,28 & 0,258 \\
\hline
\end{tabular}

$\overline{\mathrm{AB}}=$ água bruta.

Os valores de COD para a água bruta variaram de 4,592 a 18,76 mg/L para a água com cor baixa e de 14,53 a $30,13 \mathrm{mg} / \mathrm{L}$ para a água com cor elevada.

Os valores de COD e Abs $254 \mathrm{~nm}$ da água bruta foram considerados elevados, embora tenham ocorrido exceções para as dosagens de 3 e $5 \mathrm{mg} / \mathrm{L}$ de APA.

Tais resultados são atribuídos à matéria orgânica proveniente dos meios de cultura e à substância húmica (SH) adicionadas à água de estudo. Acreditase que a SH teve sua contribuição uma vez que, para a água com cor elevada os valores de COD e Abs $254 \mathrm{~nm}$ foram maiores do que para a água com cor baixa.

Verificou-se aumento significativo dos parâmetros COD e UV-254 nm após aplicação do ácido peracético para todos os ensaios, exceto para a dosagem aplicada de APA de $3 \mathrm{mg} / \mathrm{L}$, cujas amostras desinfetadas apresentaram valores baixos de $\mathrm{COD}$, em relação às demais amostras. $\mathrm{O}$ ocorrido foi considerado anomalia e não foi possivel explica-lo.

O aumento do COD e da absorbância UV-254 nm após desinfecção com ácido peracético, é compreensivel, visto que o mesmo decompõe-se em ácido acético que contém carbono em sua composição.

SARTORI (2004) ao desinfetar efluente de esgoto sanitário com ácido peracético observou aumento do conteúdo orgânico do efluente. Em relação ao COT, a 
adição de APA aumentou o COT entre 1,00 e 1,42 mg/L. E para a DQO a adição de APA causou aumento médio de 14 a $23 \mathrm{mg} / \mathrm{L}$ na DQO.Aliás, segundo Kitis (2003), essa é a maior desvantagem da desinfecção com ácido peracético "o aumento do conteúdo orgânico no efluente, podendo provocar recrescimento microbiano, pois o ácido acético além de estar na mistura do ácido peracético também é formado após a decomposição do produto”.

\section{3 - Desinfecção com ozônio}

\subsection{1 - Produção de ozônio}

Antes de se realizarem os ensaios de desinfecção com ozônio foi necessário quantificar a produção de ozônio, gerada pelo equipamento Qualid'or. Os resultados obtidos estão relacionados na Tabela 5.11. Na Figura 5.26 está representada a produção de ozônio em relação a vazão de oxigênio. A equação (1) foi obtida por regressão múltipla e relaciona a produção de ozônio com a vazão de oxigênio.

$$
\begin{aligned}
& Y=7 \times 10^{-5} X^{2}+0,0201 X \\
& \mathrm{R}^{2}=0,8831
\end{aligned}
$$

$\mathrm{X}$ : Vazão de oxigênio $(\mathrm{L} / \mathrm{h})$

Tabela 5.11 - Produção de ozônio para diferentes vazões de oxigênio utilizando o Método Iodométrico.

\begin{tabular}{cc}
\hline Vazão de oxigênio $(\mathbf{L} / \mathbf{h})$ & Produção de ozônio $(\mathbf{g} / \mathbf{h})$ \\
\hline 0 & 0 \\
10 & 0,558 \\
20 & 0,552 \\
40 & 0,746 \\
60 & 0,978 \\
80 & 1,088 \\
100 & 1,241 \\
130 & 1,298 \\
160 & 1,557 \\
\hline
\end{tabular}




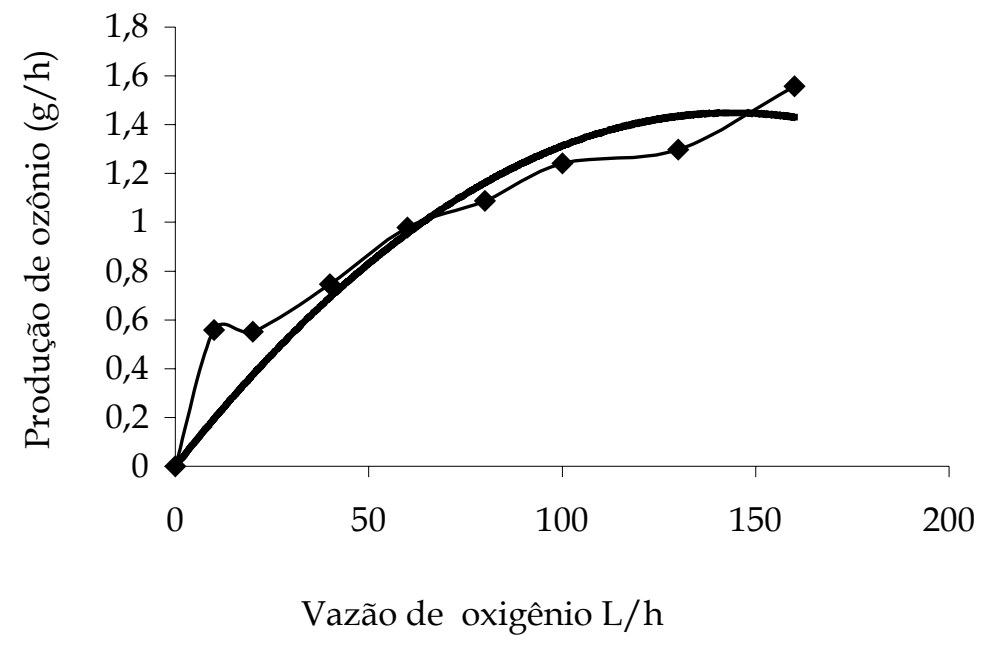

Figura 5.26 - Produção de ozônio do equipamento Qualid'or em relação à vazão de oxigênio.

\subsection{2 - Inativação de E. coli, colifagos e C. perfringens com ozônio}

Os resultados de inativação de E. coli, colifagos e C. perfringens com ozônio para a água de estudo com características de cor baixa estão apresentados na Tabela 5.12 e para a água de estudo com características de cor elevada na Tabela 5.13.

Para cada concentração de ozônio aplicado 2,0; 3,0; 4,0 e 5,0 mg/L nos progressivos tempos de contato $5 ; 10 ; 15$ e 20 minutos foram quantificadas as concentrações finais de E. coli (UFC/100 mL), colifagos (UFP/100 mL) e C. perfringens (NMP/100 mL) dos microrganismos indicadores. A concentração inicial de microrganismos adicionados à água foi variável conforme a água de estudo. 
Tabela 5.12 - Inativação de E. coli, colifagos e C. perfringens em função do tempo de contato e concentração efetiva de ozônio, para a água de estudo com cor baixa.

\begin{tabular}{|c|c|c|c|c|c|c|c|c|}
\hline \multirow{2}{*}{$\begin{array}{l}\text { Ozônio } \\
\text { aplicado } \\
\text { (mg/L) }\end{array}$} & \multirow[t]{2}{*}{$\begin{array}{c}\text { Tempo } \\
\text { (min) }\end{array}$} & & $\begin{array}{l}\text { lii } \\
\text { nativação }\end{array}$ & Col & $\begin{array}{l}\text { agos } \\
\text { Inativação }\end{array}$ & C. per & $\begin{array}{l}\text { ringens } \\
\text { Inativação }\end{array}$ & \multirow{2}{*}{$\begin{array}{c}\text { Concentração } \\
\text { efetiva de } \\
\text { Ozônio }(\mathrm{mg} / \mathrm{L})\end{array}$} \\
\hline & & $(\mathrm{N} / \mathrm{No})$ & & $(\mathrm{N} / \mathrm{No})$ & & (N/No) & & \\
\hline \multirow{4}{*}{2,0} & 5 & $3,0 \times 10^{-2}$ & 1,52 & $2,3 \times 10^{-1}$ & 0,65 & $6,8 \times 10^{-1}$ & 0,17 & 0,20 \\
\hline & 10 & $2,5 \times 10^{-2}$ & 1,60 & $2,3 \times 10^{-1}$ & 0,65 & $4,0 \times 10^{-2}$ & 1,40 & 0,20 \\
\hline & 15 & $1,1 \times 10^{-2}$ & 1,95 & $3,3 \times 10^{-1}$ & 0,49 & $4,0 \times 10^{-2}$ & 1,40 & 0,20 \\
\hline & 20 & $8,0 \times 10^{-3}$ & 2,10 & $1,0 \times 10^{-1}$ & 1,00 & $4,0 \times 10^{-2}$ & 1,40 & 0,20 \\
\hline \multirow{4}{*}{3,0} & 5 & $6,0 \times 10^{-3}$ & 2,22 & $3,6 \times 10^{-1}$ & 0,43 & $6,9 \times 10^{-1}$ & 0,16 & 0,60 \\
\hline & 10 & $3,0 \times 10^{-3}$ & 2,52 & $4,7 \times 10^{-2}$ & 1,32 & $6,9 \times 10^{-1}$ & 0,16 & 0,70 \\
\hline & 15 & $1,0 \times 10^{-3}$ & 3,00 & $6,8 \times 10^{-3}$ & 2,16 & $1,2 \times 10^{-1}$ & 0,92 & 0,80 \\
\hline & 20 & $1,0 \times 10^{-4}$ & 4,00 & $2,0 \times 10^{-3}$ & 2,68 & $6,0 \times 10^{-2}$ & 1,22 & 0,90 \\
\hline \multirow{4}{*}{4,0} & 5 & $2,0 \times 10^{-3}$ & 2,70 & $1,2 \times 10^{-4}$ & 3,92 & $3,5 \times 10^{-1}$ & 0,45 & 1,44 \\
\hline & 10 & $1,4 \times 10^{-3}$ & 2,85 & $1,2 \times 10^{-4}$ & 3,92 & $5,7 \times 10^{-2}$ & 1,24 & 1,45 \\
\hline & 15 & $8,0 \times 10^{-4}$ & 3,10 & $8,0 \times 10^{-6}$ & 5,10 & $1,4 \times 10^{-3}$ & 2,85 & 1,54 \\
\hline & 20 & $4,5 \times 10^{-4}$ & 3,35 & $4,0 \times 10^{-6}$ & 5,40 & $1,4 \times 10^{-3}$ & 2,85 & 1,54 \\
\hline \multirow{4}{*}{5,0} & 5 & $6,0 \times 10^{-4}$ & 3,22 & $6,0 \times 10^{-3}$ & 2,22 & $2,0 \times 10^{-2}$ & 1,75 & 2,30 \\
\hline & 10 & $1,6 \times 10^{-4}$ & 3,80 & $2,5 \times 10^{-3}$ & 2,60 & $2,0 \times 10^{-2}$ & 1,75 & 2,36 \\
\hline & 15 & $2,2 \times 10^{-4}$ & 3,66 & $1,0 \times 10^{-3}$ & 3,00 & $2,0 \times 10^{-2}$ & 1,75 & 2,39 \\
\hline & 20 & $4,0 \times 10^{-4}$ & 3,40 & $5,0 \times 10^{-4}$ & 3,30 & $2,0 \times 10^{-2}$ & 1,75 & 2,42 \\
\hline
\end{tabular}

Inativação: - $\log (\mathrm{N} / \mathrm{No})$; $\mathrm{N}$ : número de microrganismos no instante t; No: número de microrganismos no instante $t=0$. 
Tabela 5.13 - Inativação de $E$. coli, colifagos e C. perfringens em função do tempo de contato e concentração efetiva de ozônio, para a água de estudo com cor elevada.

\begin{tabular}{|c|c|c|c|c|c|c|c|c|}
\hline $\begin{array}{l}\text { Ozônio } \\
\text { aplicado } \\
(\mathrm{mg} / \mathrm{L})\end{array}$ & $\begin{array}{l}\text { Tempo } \\
\text { (min) }\end{array}$ & (N/No) & $\begin{array}{l}\text { nativação } \\
\text { nit }\end{array}$ & Colifagos & Inativação & $\begin{array}{l}\text { C.perf } \\
\text { (N/No) }\end{array}$ & $\begin{array}{l}\text { ringens } \\
\text { Inativação }\end{array}$ & $\begin{array}{c}\text { Concentração } \\
\text { efetiva de } \\
\text { Ozônio (mg/L) }\end{array}$ \\
\hline \multirow{4}{*}{2,0} & 5 & $4,0 \times 10^{-3}$ & 2,37 & $5,7 \times 10^{-4}$ & 3,24 & $1,0 \times 10^{-1}$ & 1,00 & 0,34 \\
\hline & 10 & $8,5 \times 10^{-5}$ & 4,06 & $5,1 \times 10^{-4}$ & 3,29 & $1,0 \times 10^{-1}$ & 1,00 & 0,32 \\
\hline & 15 & $4,2 \times 10^{-5}$ & 4,37 & $2,3 \times 10^{-4}$ & 3,64 & $1,0 \times 10^{-1}$ & 1,00 & 0,35 \\
\hline & 20 & $1,4 \times 10^{-5}$ & 4,85 & $5,7 \times 10^{-5}$ & 4,24 & $1,0 \times 10^{-1}$ & 1,00 & 0,39 \\
\hline \multirow{4}{*}{3,0} & 5 & $4,0 \times 10^{-2}$ & 1,40 & $7,0 \times 10^{-3}$ & 2,15 & $1,0 \times 10^{-1}$ & 1,00 & 0,62 \\
\hline & 10 & $1,4 \times 10^{-2}$ & 1,88 & $6,7 \times 10^{-3}$ & 2,18 & $1,0 \times 10^{-1}$ & 1,00 & 0,62 \\
\hline & 15 & $6,7 \times 10^{-3}$ & 2,18 & $5,2 \times 10^{-5}$ & 4,29 & $1,0 \times 10^{-1}$ & 1,00 & 0,64 \\
\hline & 20 & $3,4 \times 10^{-3}$ & 2,48 & $7,4 \times 10^{-5}$ & 4,13 & $8,1 \times 10^{-4}$ & 3,09 & 0,64 \\
\hline \multirow{4}{*}{4,0} & 5 & $1,5 \times 10^{-3}$ & 2,82 & $1,5 \times 10^{-2}$ & 1,82 & $5,6 \times 10^{-2}$ & 1,25 & 1,46 \\
\hline & 10 & $1,5 \times 10^{-3}$ & 2,82 & $1,3 \times 10^{-2}$ & 1,89 & $3,2 \times 10^{-2}$ & 1,49 & 1,44 \\
\hline & 15 & $1,1 \times 10^{-3}$ & 2,96 & $6,0 \times 10^{-4}$ & 3,22 & $3,2 \times 10^{-2}$ & 1,49 & 1,42 \\
\hline & 20 & $7,0 \times 10^{-4}$ & 3,15 & $2,0 \times 10^{-4}$ & 3,70 & $3,2 \times 10^{-2}$ & 1,49 & 1,52 \\
\hline \multirow{4}{*}{5,0} & 5 & $1,0 \times 10^{-3}$ & 3,00 & $8,3 \times 10^{-4}$ & 3,08 & $1,0 \times 10^{-2}$ & 2,00 & 2,17 \\
\hline & 10 & $2,0 \times 10^{-3}$ & 2,70 & $8,3 \times 10^{-4}$ & 3,08 & $1,0 \times 10^{-2}$ & 2,00 & 2,84 \\
\hline & 15 & $7,0 \times 10^{-3}$ & 2,15 & $8,3 \times 10^{-5}$ & 4,08 & $1,0 \times 10^{-2}$ & 2,00 & 2,80 \\
\hline & 20 & $1,0 \times 10^{-3}$ & 3,00 & $8,3 \times 10^{-5}$ & 4,08 & $1,0 \times 10^{-2}$ & 2,00 & 2,78 \\
\hline
\end{tabular}

Inativação: - $\log (\mathrm{N} / \mathrm{No})$; $\mathrm{N}$ : número de microrganismos no instante t; No: número de microrganismos no instante $\mathrm{t}=0$.

A partir das frações sobreviventes de E. coli, colifagos e C. perfringens, obtidas experimentalmente, foram construídos os gráficos de inativação dos microrganismos indicadores $\log \mathrm{N} / \mathrm{N}_{0}$ em função do produto C.t - concentração efetiva de ozônio $(C)$ pelo tempo de contato $(t)$, usando como origem o tempo $t=$ 0 correspondente ao tempo de aplicação do ozônio na água.

Os resultados da inativação dos indicadores com ozônio para a água de estudo com cor baixa estão apresentados nas Figuras 5.27 a 5.30 . 


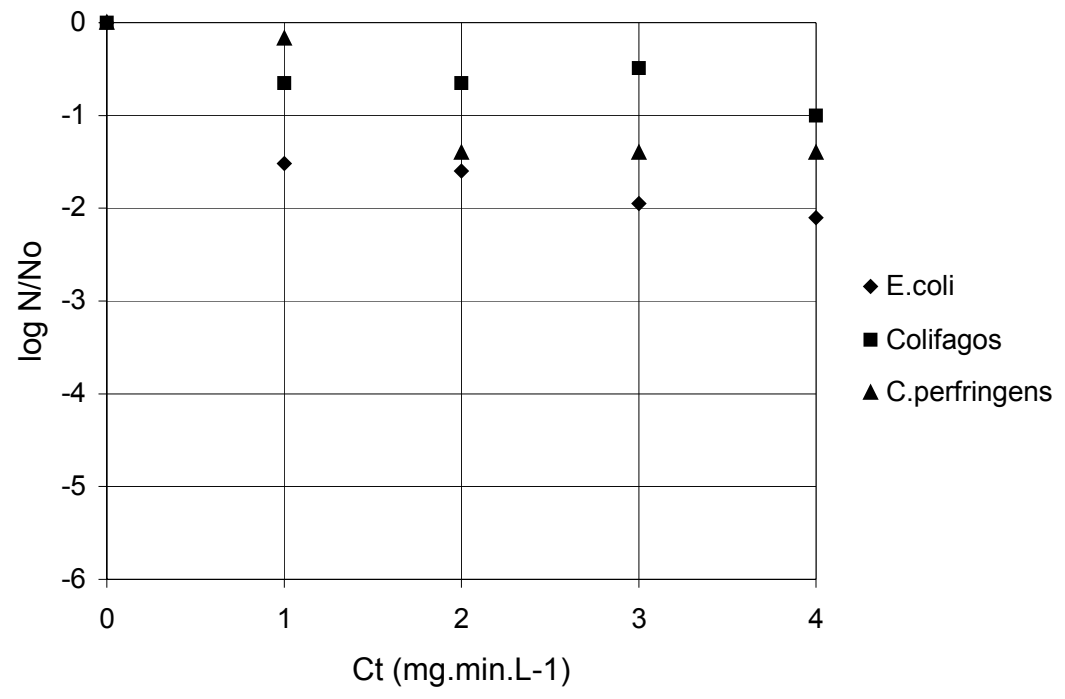

Figura 5.27 - Inativação de E. coli, colifagos e C. perfringens para 2,0mg/L de ozônio aplicado e água de estudo com cor baixa.

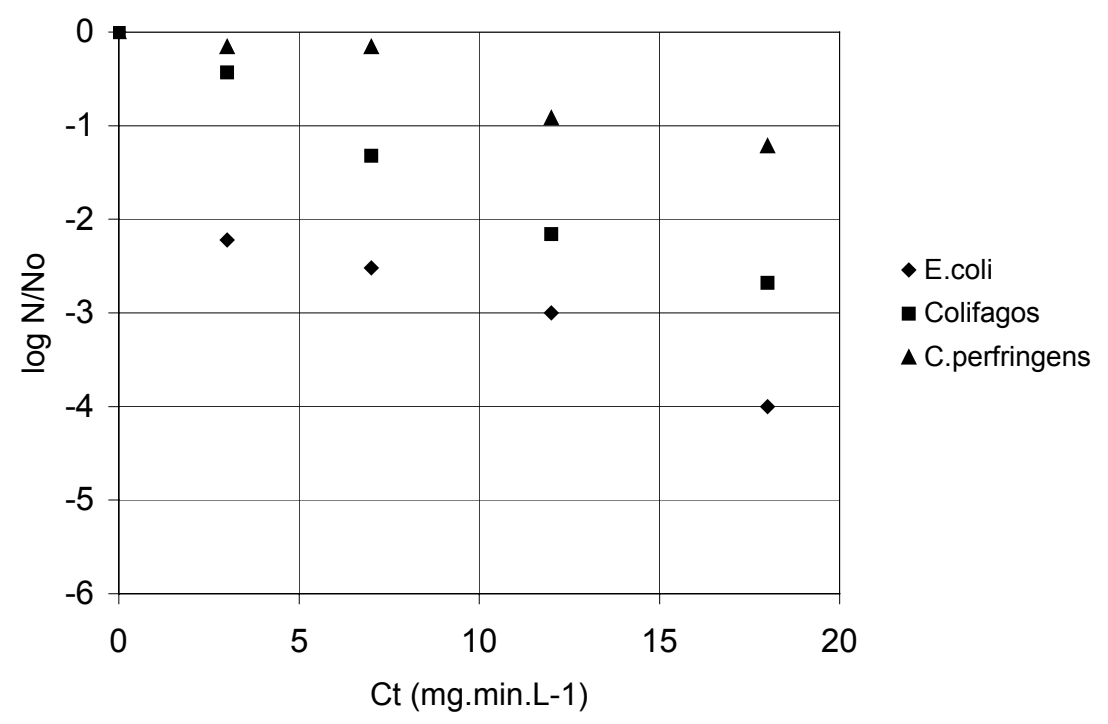

Figura 5.28 - Inativação de E. coli, colifagos e C. perfringens para 3,0mg/L de ozônio aplicado e água de estudo com cor baixa. 


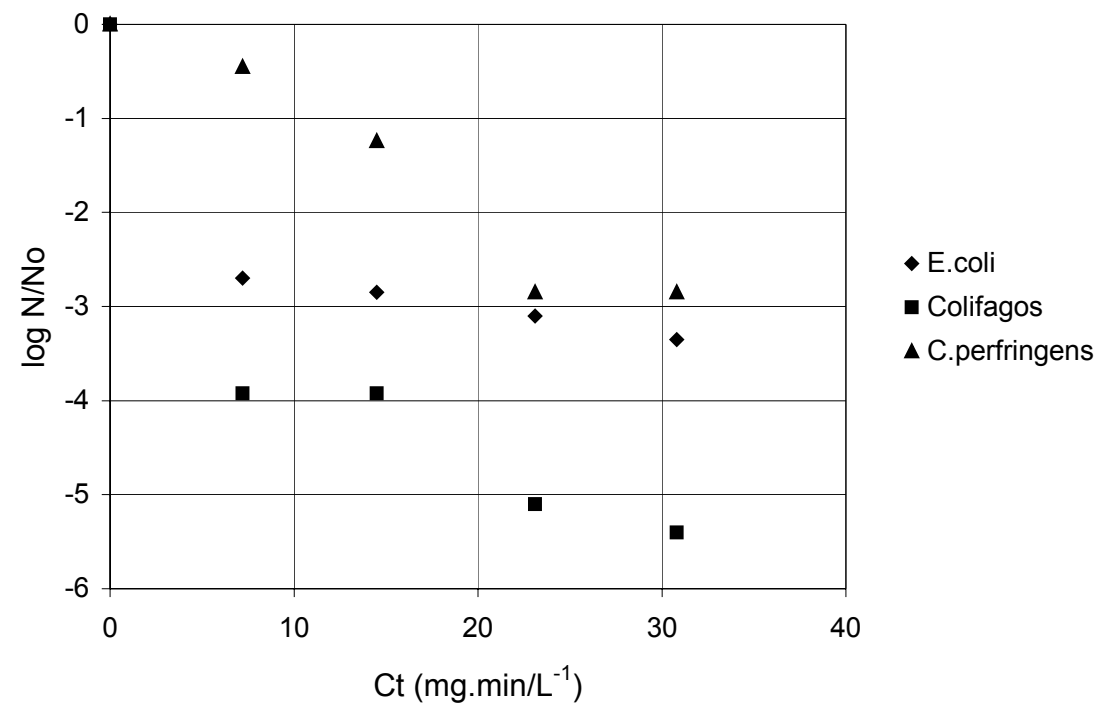

Figura 5.29 - Inativação de E. coli, colifagos e C. perfringens para 4,0mg/L de ozônio aplicado e água de estudo com cor baixa.

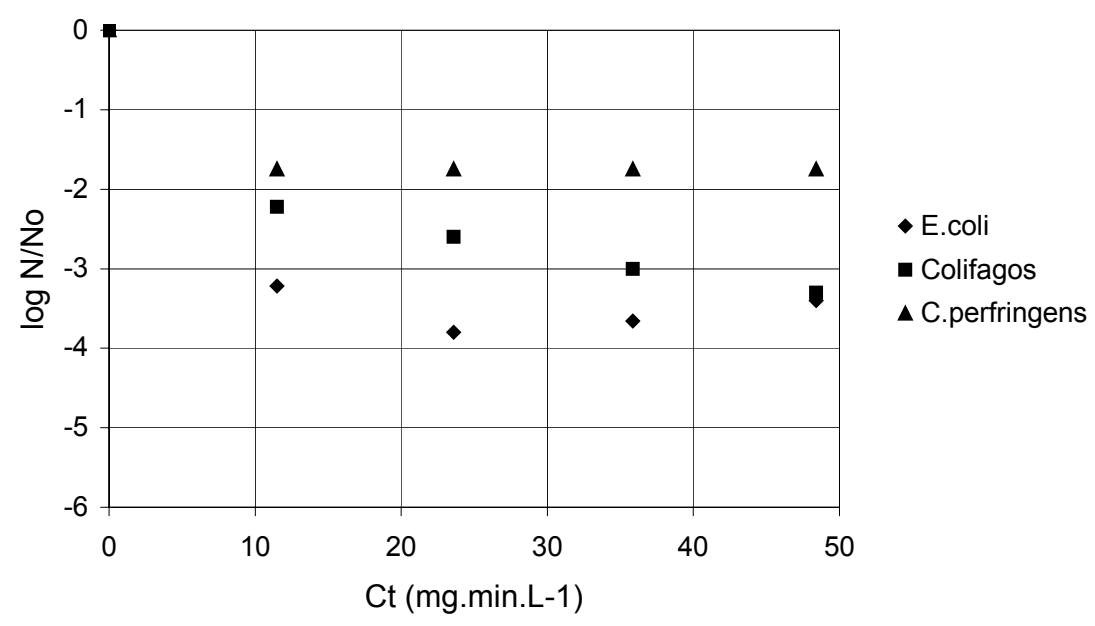

Figura 5.30 - Inativação de E. coli, colifagos e C. perfringens para 5,0mg/L de ozônio aplicado e água de estudo com cor baixa. 
Para a água de estudo com cor baixa, com exceção de alguns resultados, a resistência dos microrganismos indicadores ao ozônio seguiu a ordem crescente E. coli, colifagos, C. perfringens.

Obteve-se 4 log de inativação de $E$. coli para a dose de $\mathrm{O}_{3}$ aplicado de 3 $\mathrm{mg} / \mathrm{L}$ e tempo de contato de 20 minutos ( $\mathrm{Ct}=18 \mathrm{mg} \cdot \mathrm{min} / \mathrm{L}$ ). A menor inativação de E. coli foi de 1,52 log obtida para a dose de $\mathrm{O}_{3}$ aplicada de 2 $\mathrm{mg} / \mathrm{L}$ e 5 minutos de contato $(\mathrm{Ct}=1 \mathrm{mg} \cdot \mathrm{min} / \mathrm{L})$. Geralmente, ocorreu correlação entre as maiores inativações de E. coli, as doses aplicadas e tempos de contato mais elevados.

Em relação aos colifagos a menor inativação de 0,16 log foi obtida para a dose de $\mathrm{O}_{3}$ aplicado de $3 \mathrm{mg} / \mathrm{L}$ e 5 minutos de contato ( $\mathrm{Ct}=3 \mathrm{mg} \cdot \mathrm{min} / \mathrm{L}$ ) e a maior inativação de 5,40 log, para a dose aplicada de $4 \mathrm{mg} / \mathrm{L}$ e tempo de contato de 20 minutos ( $\mathrm{Ct}=30,8 \mathrm{mg} \cdot \mathrm{min} / \mathrm{L}$ ). Para esse microrganismo ocorreu menor correlação - em relação à E. coli - entre a dose aplicada, o tempo de contato e as inativações observadas.

Para C. perfringens a menor inativação observada foi de 0,16 log para a dose de $\mathrm{O}_{3}$ aplicada de $2 \mathrm{mg} / \mathrm{L}$ e tempos de contato de 5 e 10 minutos. A maior inativação observada foi de 2,85 log para os tempos de contato de 15 e 20 minutos ( $\mathrm{Ct}=23,1$ e 30,8 mg.min/L, respectivamente). Para a dose de $\mathrm{O}_{3}$ aplicada de $5 \mathrm{mg} / \mathrm{L}$ e todos os tempos de contato empregados, a população dessa bactéria permaneceu estável na ordem de $10^{5} \mathrm{NMP} / 100 \mathrm{~mL}$.

A elevada resistência dessa bactéria ao ozônio é reportada por TYRRELL et al. (1995) que observaram que esporos de C. perfringens foram relativamente insensiveis à inativação com ozônio.

Também, SARTORI (2004) desinfetou efluentes secundários de esgoto sanitário com ozônio e obteve eficiências de inativação de C. perfringens que variaram de 75,00 a 99,67\%, embora, a população de C. perfringens tenha permanecido estável, na ordem de aproximadamente $10^{4} \mathrm{NMP} / 100 \mathrm{~mL}$, mesmo com o aumento do tempo de contato e da dose de ozônio consumida, denotando a relativa resistência dessa bactéria à desinfecção com ozônio.

Os resultados da inativação dos microrganismos com ozônio para a água de estudo com cor elevada estão apresentados nas Figuras 5.31 a 5.34. 


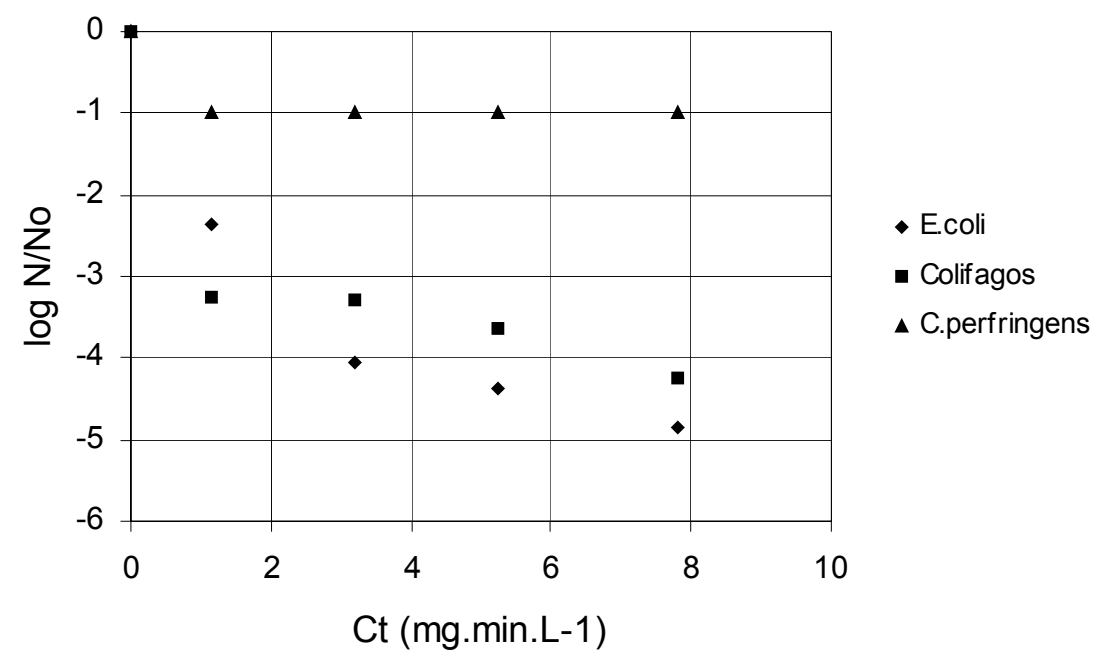

Figura 5.31 - Inativação de E. coli, colifagos e C. perfringens para 2,0mg/L de ozônio aplicado e água de estudo com cor elevada.

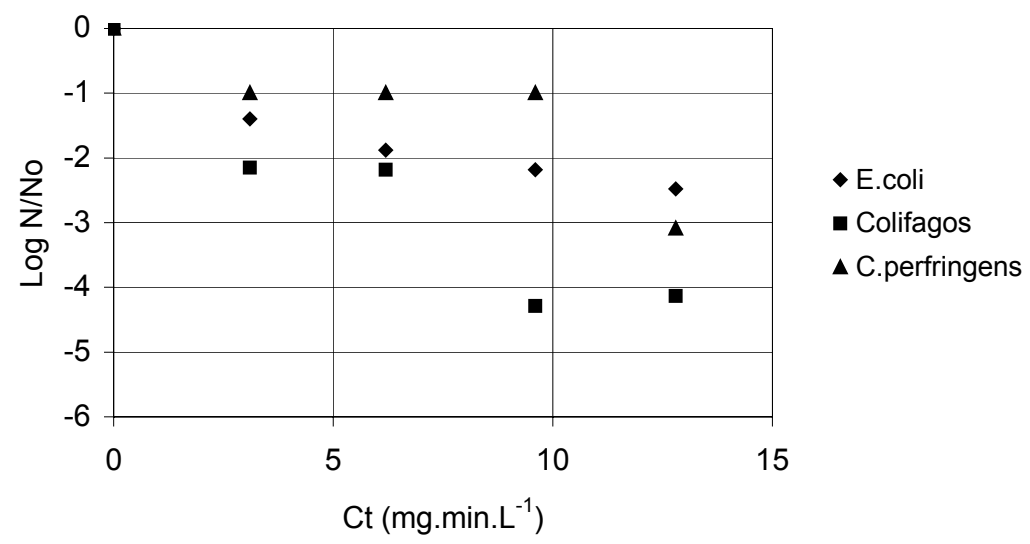

Figura 5.32 - Inativação de E. coli, colifagos e C. perfringens para 3,0mg/L de ozônio aplicado e água de estudo com cor elevada. 


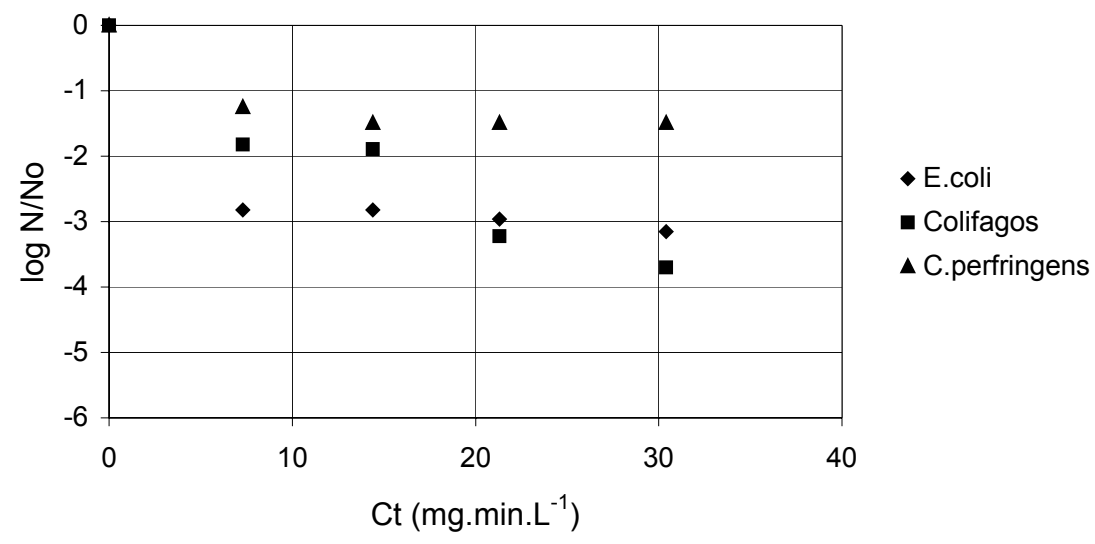

Figura 5.33 - Inativação de E. coli, colifagos e C. perfringens para 4,0mg/L de ozônio aplicado e água de estudo com cor elevada.

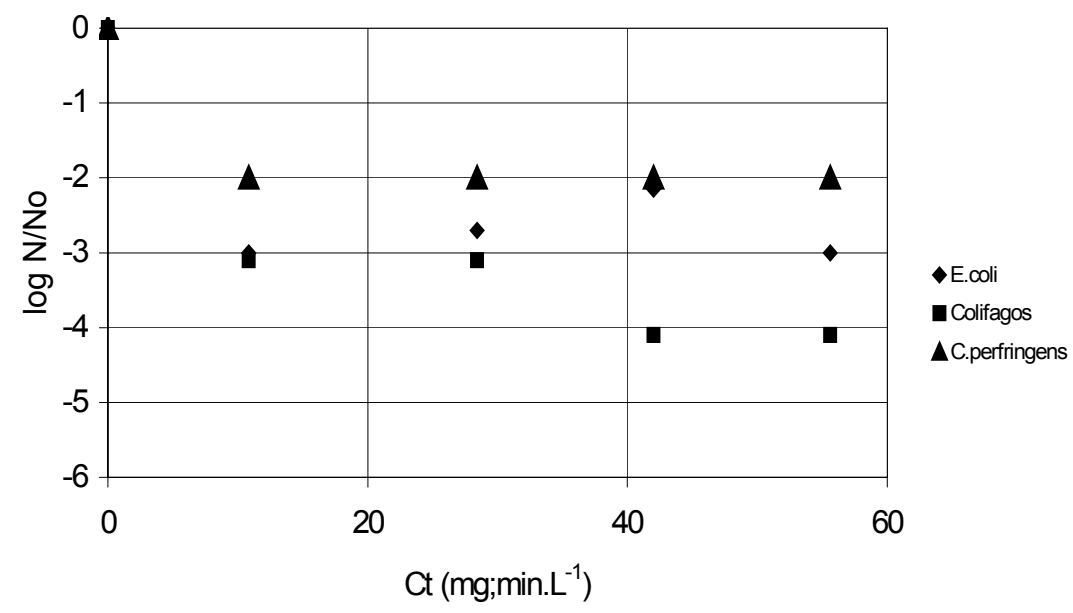

Figura 5.34 - Inativação de E. coli, colifagos e C. perfringens para 5,0mg/L de ozônio aplicado e água de estudo com cor elevada.

As taxas de inativação dos indicadores foram similares para as duas águas de estudo, denotando que não houve influência da cor sobre efetividade da ozonização. 
Para os experimentos realizados com a água de estudo com cor elevada a ordem de inativação dos indicadores com ozônio seguiu: colifagos $<E$. coli< C. perfringens, o que confirma alguns estudos reportados na literatura.

Inativações de colifagos maiores do que $4 \mathrm{log}$ foram obtidas para algumas dosagens e tempos de contato empregados. A maior inativação foi de 4,29 log, obtida para a dose de $\mathrm{O}_{3}$ aplicado de $3 \mathrm{mg} / \mathrm{L}$ e 15 minutos de contato $(\mathrm{Ct}=9,6 \mathrm{mg} \cdot \mathrm{min} / \mathrm{L})$. A menor inativação observada foi para a dosagem aplicada de $4 \mathrm{mg} / \mathrm{L}$ e 5 minutos de contato ( $\mathrm{Ct}=7,3 \mathrm{mg} \cdot \mathrm{min} / \mathrm{L})$.

Também para a bactéria $E$. coli obteve-se até 4 log de inativação para algumas dosagens aplicadas e tempos de contato empregados. Entretanto, para esses últimos experimentos (água com cor elevada), geralmente, as porcentagens de inativação para essa bactéria foram menores do que para os colifagos. A maior inativação de E. coli foi de 4,85 log, obtida para a dosagem aplicada de $2 \mathrm{mg} / \mathrm{L}$ e 20 minutos de contato ( $\mathrm{Ct}=7,8 \mathrm{mg} \cdot \mathrm{min} / \mathrm{L}$ ). A menor inativação observada foi de 1,40 log para a dose de $3 \mathrm{mg} / \mathrm{L}$ e tempo de contato de 5 minutos $(\mathrm{Ct}=3,1 \mathrm{mg} \cdot \mathrm{min} / \mathrm{L})$.

TYRRELL et al. (1995) compararam cloro e ozônio na inativação de bactérias e virus provenientes de efluentes secundários de esgoto sanitário. Com a cloração observaram redução maior do que 100 vezes nas densidades de coliformes fecais e enterococos. Entretanto, redução menor do que 10 vezes foi observada nas densidades dos dois grupos de bacteriófagos testados (específicos e somáticos). Em contraste, o tratamento com ozônio resultou em redução maior do que 100 vezes nas densidades dos bacteriófagos específicos e somáticos, enquanto que a redução de bactérias vegetativas foi menor do que 30 vezes para ambos indicadores. Os autores concluíram que o ozônio é muito efetivo como virucida, porém, é menos efetivo que o cloro na eliminação de bactérias vegetativas.

SARTORI (2004) verificou que o ozônio foi eficiente desinfetante viral, especialmente quando comparado ao ácido peracético e permanganato de potássio. Valores de até $100 \%$ de inativação de colifagos foram obtidos quando se empregou ozônio como desinfetante com $\mathrm{Ct}=270 \mathrm{mg} \cdot \mathrm{min} / \mathrm{L}$. 
Para a bactéria $C$. perfringens os resultados não diferiram muito dos anteriores (água de estudo com cor baixa). Obteve-se geralmente de 1 a 2 log de inativação para todas as dosagens de ozônio aplicadas e tempos de contato empregados. Para a dose aplicada de $\mathrm{O}_{3}$ de $5 \mathrm{mg} / \mathrm{L}$ observou-se 2 log de inativação para todos os tempos de contato empregados, assim, valores mais elevados de Ct não contribuíram para aumentar a porcentagem de inativação dessa bactéria. A sua população remanescente foi da ordem de $10^{5} \mathrm{NMP} / 100$ $\mathrm{mL}$.

Devido o ozônio ser excelente virucida, mas não tão efetivo quanto o cloro na eliminação de bactérias vegetativas (TYRREL et al., 1995), pesquisas têm sido desenvolvidas para examinar a efetividade da combinação de agentes desinfetantes tais como a combinação ozônio / cloro e ozônio / radiação UV. Quando os desinfetantes são usados em combinações apropriadas, esses estudos reportam rápida inativação de vírus e bactérias com limitada formação de subprodutos.

A proposta da desinfecção combinada ozônio / cloro é altamente promissora, uma vez que o ozônio é muito eficiente como oxidante e excelente virucida. Por sua vez, o cloro como desinfetante secundário, supre a necessidade de manutenção do residual desinfetante, fundamental para a água de abastecimento, que a ozonização não oferece.

\subsection{3 - Influência das características da água de estudo}

Os resultados dos ensaios de desinfecção com ozônio realizados para a água de estudo com cor baixa e cor elevada estão apresentados nas Tabelas A18 a A-25 (em anexo).

Para a realização dos experimentos as doses aplicadas de ozônio foram de 2, 3, 4 e $5 \mathrm{mg} / \mathrm{L}$ e os tempos de contato empregados foram de $5 ; 10 ; 15$ e 20 minutos.

Da literatura sabe-se que fatores como temperatura, $\mathrm{pH}$ e presença de compostos orgânicos e inorgânicos afetam a eficiência da desinfecção com ozônio. No entanto, a taxa de decomposição do ozônio em função de cada um 
desses parâmetros é algo bastante complexo de ser discutido. Observou-se, entretanto, que não houve variações significativas entre os resultados da água de estudo bruta e após a ozonização, referentes aos parâmetros físico-químicos avaliados: temperatura, $\mathrm{pH}$ e alcalinidade.

$\mathrm{O} \mathrm{pH}$ da água bruta variou de 7,0 a 7,4, e o $\mathrm{pH}$ médio da água bruta foi de 7,2. Após a ozonização o pH da variou de 6,8 a 8,3 e o pH médio foi de 7,3.

A alcalinidade da água bruta variou de 83,83 a 151,70 $\mathrm{mgCaCO}_{3} / \mathrm{L}$, e a alcalinidade média foi de 106,78 $\mathrm{mgCaCO}_{3} / \mathrm{L}$. Após a ozonização a alcalinidade variou de 83,82 a $144 \mathrm{mgCaCO}_{3} / \mathrm{L}$ e a alcalinidade média foi de 100,98 $\mathrm{mg}$ $\mathrm{CaCO}_{3} / \mathrm{L}$. Ou seja, não ocorreram variações significativas na alcalinidade da água bruta e após a ozonização.

Segundo LANGLAIS (1991) a alcalinidade elevada da água inibi a formação de radicais livres, o que por sua vez, reduz a velocidade de decomposição do ozônio e favorece a reação molecular ou direta. Ainda, ocorre efeito estabilizante do bicarbonato sobre o ozônio.

A temperatura da água de estudo variou de 22 a $23^{\circ} \mathrm{C}$ para todos os experimentos.

\subsection{4 - COD e Abs UV $254 \mathrm{~nm}$}

Os resultados das análises de COD e Abs UV - 254 nm para os ensaios de desinfecção com ozônio para as duas águas de estudo estão apresentados nas Tabelas 5.14 e 5.15 . 
Tabela 5.14 - Análises de COD e Abs UV-254 nm para desinfecção com ozônio para água com cor baixa.

\begin{tabular}{c|c|c|c|c|c|c|c|c}
\hline \multirow{2}{*}{$\begin{array}{c}\mathrm{T} \\
(\mathrm{min})\end{array}$} & \multicolumn{2}{|c|}{$\mathrm{O}_{3}: 2 \mathrm{mg} / \mathrm{L}$} & \multicolumn{2}{c|}{$\mathrm{O}_{3}: 3 \mathrm{mg} / \mathrm{L}$} & \multicolumn{2}{c|}{$\mathrm{O}_{3}: 4 \mathrm{mg} / \mathrm{L}$} & \multicolumn{2}{c}{$\mathrm{O}_{3}: 5 \mathrm{mg} / \mathrm{L}$} \\
\cline { 2 - 9 } & $\mathrm{COD}$ & $\mathrm{UV}$ & $\mathrm{COD}$ & $\mathrm{UV}$ & $\mathrm{COD}$ & $\mathrm{UV}$ & $\mathrm{COD}$ & $\mathrm{UV}$ \\
& $254 \mathrm{~nm}$ & $(\mathrm{mg} / \mathrm{L})$ & $254 \mathrm{~nm}$ & $(\mathrm{mg} / \mathrm{L})$ & $254 \mathrm{~nm}$ & $\begin{array}{c}\mathrm{Cmg} / \mathrm{L}) \\
254 \mathrm{~nm}\end{array}$ \\
\cline { 2 - 9 } & $\mathrm{AB}: 10,92$ & $\mathrm{AB}: 0,043$ & $\mathrm{AB}: 9,753$ & $\mathrm{AB}: 0,284$ & $\mathrm{AB}: 55,71$ & $\mathrm{AB}: 0,087$ & $\mathrm{AB}: 65,93$ & $\mathrm{AB}: 0,080$ \\
\hline 5 & 39,28 & 0,177 & 25,05 & 0,043 & 56,04 & 0,086 & 66,54 & 0,099 \\
10 & 36,86 & 0,121 & 24,29 & 0,038 & 57,03 & 0,084 & 66,42 & 0,093 \\
15 & 39,67 & 0,093 & 24,58 & 0,030 & 56,46 & 0,084 & 66,16 & 0,096 \\
20 & 28,63 & 0,074 & 18,97 & 0,034 & 56,46 & 0,086 & 65,12 & 0,094 \\
\hline
\end{tabular}

$\mathrm{AB}=$ água bruta

Tabela 5.15 - Análises de COD e Abs UV-254 nm para desinfecção com ozônio para água com cor elevada.

\begin{tabular}{c|c|c|c|c|c|c|c|c}
\hline \multirow{2}{*}{$\mathrm{T}$} & \multicolumn{2}{|c|}{$\mathrm{O}_{3}: 2 \mathrm{mg} / \mathrm{L}$} & \multicolumn{2}{c|}{$\mathrm{O}_{3}: 3 \mathrm{mg} / \mathrm{L}$} & \multicolumn{2}{c|}{$\mathrm{O}_{3}: 4 \mathrm{mg} / \mathrm{L}$} & \multicolumn{2}{c}{$\mathrm{O}_{3}: 5 \mathrm{mg} / \mathrm{L}$} \\
\cline { 2 - 9 }$(\mathrm{min})$ & $\begin{array}{c}\mathrm{COD} \\
(\mathrm{mg} / \mathrm{L})\end{array}$ & $\begin{array}{c}\mathrm{UV} \\
254 \mathrm{~nm}\end{array}$ & $\begin{array}{c}\mathrm{COD} \\
(\mathrm{mg} / \mathrm{L})\end{array}$ & $\begin{array}{c}\mathrm{UV} \\
254 \mathrm{~nm}\end{array}$ & $\begin{array}{c}\mathrm{COD} \\
(\mathrm{mg} / \mathrm{L})\end{array}$ & $\begin{array}{c}\mathrm{UV} \\
254 \mathrm{~nm}\end{array}$ & $\begin{array}{c}\mathrm{COD} \\
(\mathrm{mg} / \mathrm{L})\end{array}$ & $\begin{array}{c}\mathrm{UV} \\
254 \mathrm{~nm}\end{array}$ \\
\cline { 2 - 9 } & $\mathrm{AB}: 33,89$ & $\mathrm{AB}: 0,073$ & $\mathrm{AB}: 24,40$ & $\mathrm{AB}: 0,047$ & $\mathrm{AB}: 31,71$ & $\mathrm{AB}: 0,245$ & AB: 41,48 & $\mathrm{AB}: 0,065$ \\
\hline 5 & 45,98 & 0,101 & 49,3 & 0,096 & 33,53 & 0,304 & 41,64 & 0,101 \\
10 & 45,38 & 0,181 & 37,41 & 0,114 & 35,05 & 0,305 & 43,03 & 0,115 \\
15 & 42,45 & 0,147 & 37,02 & 0,101 & 25,73 & 0,290 & 42,74 & 0,124 \\
20 & 37,28 & 0,142 & 31,67 & 0,091 & 29,88 & 0,293 & 42,81 & 0,103 \\
\hline
\end{tabular}

$\mathrm{AB}=$ água bruta

De maneira análoga ao ocorrido anteriormente os elevados valores de COD e absorbância UV $254 \mathrm{~nm}$ da água de estudo bruta devem-se à matéria orgânica proveniente dos meios de cultura e da substância húmica adicionados à água.

Para todas as dosagens e tempos de contato empregados, verificou-se considerável aumento nas concentrações de COD e absorbância UV-254 nm após ozonização.

Tais resultados foram relacionados ao aumento do conteúdo orgânico biodegradável promovido pela ozonização. 
Segundo DEMERS \& RENNER (1992) apud USEPA (1999) o ozônio é efetivo na oxidação parcial de compostos orgânicos presentes na água convertendo-os em compostos biodegradáveis, que podem ser removidos posteriormente por filtração biológica. A oxidação parcial promove aumento dos compostos orgânicos de baixo peso molecular, que são mais facilmente biodegradáveis. Segundo USEPA (1999) as dosagens de ozônio tipicamente usadas para desinfecção de água são capazes de causar aumento da fração do carbono orgânico biodegradável.

O ozônio reage com material húmico e outras substâncias orgânicas e inorgânicas e causa efetiva mudança estrutural nas mesmas. Dentre as mudanças ocorridas nas substâncias húmicas e orgânicas incluem: forte e rápido decréscimo na cor e absorbância UV, devido à perda de aromaticidade e despolimerização (CAMEL \& BERMOND, 1998 apud GRAHAM, 1999); pequena redução no COT (cerca de $10 \%$ para $1 \mathrm{mgO}_{3} / \mathrm{mgC}$ ); pequeno decréscimo nas frações de elevado peso molecular aparente e pequeno aumento nas frações menores; ainda, significativo aumento das funções carboxílicas e formação de subprodutos da ozonização (LANGLAIS, 1991).

Esses subprodutos têm sido reportados por LANGLAIS (1991), SINGER (1999), GRAHAM (1999) e USEPA (1999) com sendo principalmente: aldeídos (formaldeído, acetaldeído, glioxal, metilglioxal e ácidos carboxílicos (fórmico, acético, glioxílico, pirúvico e cetomalônico) que contribuem para o conteúdo de carbono orgânico biodegradável da água ozonizada. Se não propriamente controlados esses subprodutos da oxidação podem levar à formação de biofilmes e recrescimento microbiano no sistema de distribuição de água. 


\section{4 - Desinfecção combinada: ozônio / cloro}

$\mathrm{O}$ ozônio $\left(\mathrm{O}_{3}\right)$ e o cloro $\left(\mathrm{Cl}_{2}\right)$ foram testados individualmente e seqüencialmente.

A desinfecção combinada ozônio / cloro foi realizada somente para a água de estudo com cor baixa.

Os ensaios individuais foram realizados para as doses aplicadas de ozônio de 2,0; 3,0 e 5,0 mg/L; as doses de cloro foram de 2,0 e 5,0 mg/L. A desinfecção seqüencial consistiu das combinações de dosagens apresentadas na Tabela 5.16.

Tabela 5.16 - Combinações dos desinfetantes $0_{3}$ e $\mathrm{Cl}_{2}$

\begin{tabular}{|c|c|c|}
\hline $\begin{array}{c}\text { Combinações dos } \\
\text { desinfetantes }\end{array}$ & $0_{3}(\mathrm{mg} / \mathrm{L})$ & $\mathrm{Cl}_{2}(\mathrm{mg} / \mathrm{L})$ \\
\hline 1 & 2 & 2 \\
\hline 2 & 3 & 2 \\
\hline 3 & 5 & 2 \\
\hline 4 & 2 & 5 \\
\hline
\end{tabular}

Os tempos de contato empregados foram de 5; 10; 15 e 20 minutos tanto para os ensaios individuais como para a etapa seqüencial, sendo que, para a etapa seqüencial os tempos referidos foram divididos em intervalos de tempo aproximadamente iguais entre os dois desinfetantes, de forma que, o tempo de contato final para a desinfecção combinada fosse de $5 ; 10 ; 15$ e 20 minutos.

Os resultados das inativações (I) dos microrganismos E. coli, colifagos e C. perfringens, obtidos nos ensaios de desinfecção com os processos individuais e com o processo combinado foram sumarizados e estão apresentados nas Tabelas 5.17, 5.18 e 5.19, respectivamente.Com a finalidade de facilitar a compreensão dos resultados, no presente capítulo faz-se referência às dosagens aplicadas dos desinfetantes e não aos seus respectivos 
residuais, nos diferentes tempos de contato. Ainda, são apresentadas as inativações obtidas para as dosagens aplicadas dos desinfetantes após cada tempo de contato e não o número inicial e final dos microrganismos, os quais estão apresentados no Anexo (Tabelas A 26 a A 28).

Para verificação do sinergismo, que pode ou não ocorrer quando se emprega processo de desinfecção combinado ou seqüencial, foi usado o modelo adotado por FINCH et al. (2000), em que: Sinergismo $=\mathrm{I}_{\mathrm{r}}-\left(\mathrm{I}_{1}+\mathrm{I}_{2}\right)$; em que $\mathrm{I}_{\mathrm{r}}$ é a inativação resultante do processo seqüencial, $\mathrm{I}_{1}$ a inativação observada para o desinfetante primário (ozônio) e $\mathrm{I}_{2}$ a inativação observada para o desinfetante secundário (cloro); inativação I = - $\log$ N/No.

Os cálculos para verificação de sinergismo, na etapa da desinfecção seqüencial, para os três microrganismos empregados, encontram-se sumarizados na Tabela 5.20.

Tabela 5.17 - Inativação de E. coli empregando o processo combinado $\mathrm{O}_{3} / \mathrm{Cl}_{2}$.

\begin{tabular}{|c|c|c|c|c|c|c|c|c|c|}
\hline \multicolumn{4}{|c|}{$\begin{array}{c}\text { Desinfetante primário: } \mathrm{O}_{3} \\
\log \mathrm{N} / \text { No para as } \\
\text { dosagens aplicadas } \\
(\mathrm{mg} / \mathrm{L})\end{array}$} & \multicolumn{2}{|c|}{$\begin{array}{c}\text { Desinfetante } \\
\text { secundário: } \mathrm{Cl}_{2} \\
\text { log } \mathrm{N} / \mathrm{No} \text { para } \\
\text { as dosagens } \\
\text { aplicadas }(\mathrm{mg} / \mathrm{L})\end{array}$} & \multicolumn{4}{|c|}{$\begin{array}{c}\text { Processo combinado: } \mathrm{O}_{3} / \mathrm{Cl}_{2} \\
\log \mathrm{N} / \text { No para as combinações indicadas } \\
(\mathrm{mg} / \mathrm{L})\end{array}$} \\
\hline $\begin{array}{l}\text { Tempo } \\
\text { (min) }\end{array}$ & 2,0 & 3,0 & 5,0 & 2,0 & 5,0 & $\begin{array}{l}\mathrm{O}_{3}: 2,0 / \\
\mathrm{Cl}_{2}: 2,0\end{array}$ & $\begin{array}{l}\mathrm{O}_{3}: 3,0 / \\
\mathrm{Cl}_{2}: 2,0\end{array}$ & $\begin{array}{l}\mathrm{O}_{3}: 5,0 / \\
\mathrm{Cl}_{2}: 2,0\end{array}$ & $\begin{array}{l}\mathrm{O}_{3}: 2,0 / \\
\mathrm{Cl}_{2}: 5,0\end{array}$ \\
\hline 5 & 1,32 & 2,12 & 2,84 & 2 & 2,60 & 5,70 & 5,72 & 6,68 & 5,54 \\
\hline 10 & 1,54 & 2,21 & 2,96 & 2 & 2,70 & 6,02 & 6,72 & 6,98 & 6,42 \\
\hline 15 & 1,95 & 2,52 & 3,1 & 2,1 & 3,30 & 6,96 & 6,85 & 7,02 & 7,54 \\
\hline 20 & 2,1 & 2,70 & 3,22 & 2,3 & 3,50 & 7,02 & 6,96 & 7,72 & 7,76 \\
\hline
\end{tabular}


Tabela 5.18 - Inativação de colifagos empregando o processo combinado $\mathrm{O}_{3} / \mathrm{Cl}_{2}$.

\begin{tabular}{|c|c|c|c|c|c|c|c|c|c|}
\hline \multicolumn{4}{|c|}{$\begin{array}{c}\text { Desinfetante primário: } \mathrm{O}_{3} \\
\log \mathrm{N} / \text { No para as } \\
\text { dosagens aplicadas } \\
(\mathrm{mg} / \mathrm{L})\end{array}$} & \multicolumn{2}{|c|}{$\begin{array}{c}\text { Desinfetante } \\
\text { secundário: } \mathrm{Cl}_{2} \\
\text { log N/No para } \\
\text { as dosagens } \\
\text { aplicadas }(\mathrm{mg} / \mathrm{L})\end{array}$} & \multicolumn{4}{|c|}{$\begin{array}{c}\text { Processo combinado: } \mathrm{O}_{3} / \mathrm{Cl}_{2} \\
\log \mathrm{N} / \text { No para as combinações indicadas } \\
(\mathrm{mg} / \mathrm{L})\end{array}$} \\
\hline $\begin{array}{l}\text { Tempo } \\
\text { (min) }\end{array}$ & 2,0 & 3,0 & 5,0 & 2,0 & 5,0 & $\begin{array}{l}\mathrm{O}_{3}: 2,0 / \\
\mathrm{Cl}_{2}: 2,0\end{array}$ & $\begin{array}{l}\mathrm{O}_{3}: 3,0 / \\
\mathrm{Cl}_{2}: 2,0\end{array}$ & $\begin{array}{l}\mathrm{O}_{3}: 5,0 / \\
\mathrm{Cl}_{2}: 2,0\end{array}$ & $\begin{array}{l}\mathrm{O}_{3}: 2,0 / \\
\mathrm{Cl}_{2}: 5,0\end{array}$ \\
\hline 5 & 2,31 & 3,09 & 3,64 & 1 & 2,30 & 5,06 & 5,24 & 5,72 & 6,02 \\
\hline 10 & 2,32 & 3,22 & 3,70 & 1 & 2,48 & 5,70 & 5,68 & 6,02 & 6,24 \\
\hline 15 & 2,37 & 3,29 & 3,85 & 1,30 & 3,12 & 6,70 & 6,27 & 6,98 & 6,27 \\
\hline 20 & 3 & 3,52 & 4,1 & 1,82 & 3,22 & 6,98 & 6,48 & 7,02 & 6,96 \\
\hline
\end{tabular}

Tabela 5.19 - Inativação de C. perfringens empregando o processo combinado $\mathrm{O}_{3} / \mathrm{Cl}_{2}$.

\begin{tabular}{|c|c|c|c|c|c|c|c|c|c|}
\hline \multicolumn{4}{|c|}{$\begin{array}{c}\text { Desinfetante primário: } \mathrm{O}_{3} \\
\log \mathrm{N} / \text { No para as } \\
\text { dosagens aplicadas } \\
(\mathrm{mg} / \mathrm{L})\end{array}$} & \multicolumn{2}{|c|}{$\begin{array}{c}\text { Desinfetante } \\
\text { secundário: } \mathrm{Cl}_{2} \\
\text { log N/No para } \\
\text { as dosagens } \\
\text { aplicadas (mg/L) }\end{array}$} & \multicolumn{4}{|c|}{$\begin{array}{c}\text { Processo combinado: } \mathrm{O}_{3} / \mathrm{Cl}_{2} \\
\log \mathrm{N} / \text { No para as combinações indicadas } \\
(\mathrm{mg} / \mathrm{L})\end{array}$} \\
\hline $\begin{array}{l}\text { Tempo } \\
\text { (min) }\end{array}$ & 2,0 & 3,0 & 5,0 & 2,0 & 5,0 & $\begin{array}{l}\mathrm{O}_{3}: 2,0 / \\
\mathrm{Cl}_{2}: 2,0\end{array}$ & $\begin{array}{l}\mathrm{O}_{3}: 3,0 / \\
\mathrm{Cl}_{2}: 2,0\end{array}$ & $\begin{array}{l}\mathrm{O}_{3}: 5,0 / \\
\mathrm{Cl}_{2}: 2,0\end{array}$ & $\begin{array}{l}\mathrm{O}_{3}: 2,0 / \\
\mathrm{Cl}_{2}: 5,0\end{array}$ \\
\hline 5 & 1,0 & 1,49 & 1,88 & 0,52 & 1,18 & 2,0 & 2,24 & 3,0 & 3,22 \\
\hline 10 & 1,02 & 1,72 & 2,54 & 0,96 & 2,22 & 2,22 & 3,0 & 3,34 & 3,27 \\
\hline 15 & 1,25 & 2,05 & 3,0 & 1,18 & 2,72 & 3,0 & 3,0 & 4,02 & 3,54 \\
\hline 20 & 1,30 & 2,32 & 3,25 & 1,22 & 3,0 & 3,0 & 3,0 & 4,68 & 4,70 \\
\hline
\end{tabular}


Tabela 5.20 - Verificação de sinergismo empregando o processo seqüencial ozônio/ cloro para os microrganismos indicadores E. coli, colifagos e C. perfringens.

\begin{tabular}{|c|c|c|c|c|}
\hline $\begin{array}{c}\text { Tempo } \\
(\mathrm{min})\end{array}$ & $\begin{array}{c}\text { Doses combinadas } \\
(\mathrm{mg} / \mathrm{L})\end{array}$ & $\begin{array}{c}\text { E. coli } \\
\text { Log N/No }\end{array}$ & $\begin{array}{c}\text { Colifagos } \\
\text { Log N/No }\end{array}$ & $\begin{array}{c}\text { C. perfringens } \\
\text { Log N/No }\end{array}$ \\
\hline 5 & & 2,38 & 1,75 & 0,48 \\
10 & $2,0 \mathrm{O}_{3} / 2,0 \mathrm{Cl}_{2}$ & 2,48 & 2,38 & 0,24 \\
15 & & 2,91 & 3,03 & 0,57 \\
20 & & 1,6 & 2,16 & 0,48 \\
\hline 5 & $3,0 \mathrm{O}_{3} / 2,0 \mathrm{Cl}_{2}$ & 2,51 & 1,15 & 0,23 \\
10 & & 2,23 & 1,46 & 0,32 \\
15 & & 1,96 & 1,68 & $-0,23$ \\
20 & & 1,84 & 1,08 & $-0,54$ \\
\hline 5 & $5,0 \mathrm{O}_{3} / 2,0 \mathrm{Cl}_{2}$ & 2,02 & 1,32 & 0,6 \\
10 & & 1,82 & 1,83 & $-0,16$ \\
15 & & 2,2 & 1,1 & $-0,16$ \\
20 & & 1,62 & 1,41 & 0,21 \\
\hline 5 & & 2,18 & 1,44 & 1,04 \\
10 & $2,0 \mathrm{O}_{3} / 5,0 \mathrm{Cl}_{2}$ & 2,29 & 0,78 & $-0,43$ \\
15 & & 2,16 & 0,74 & 0,4 \\
\hline
\end{tabular}

Com os resultados de inativação de $E$. coli obtidos experimentalmente e apresentados na Tabela 5.17 foram construídas as Figuras 5.35 a 5.38. 


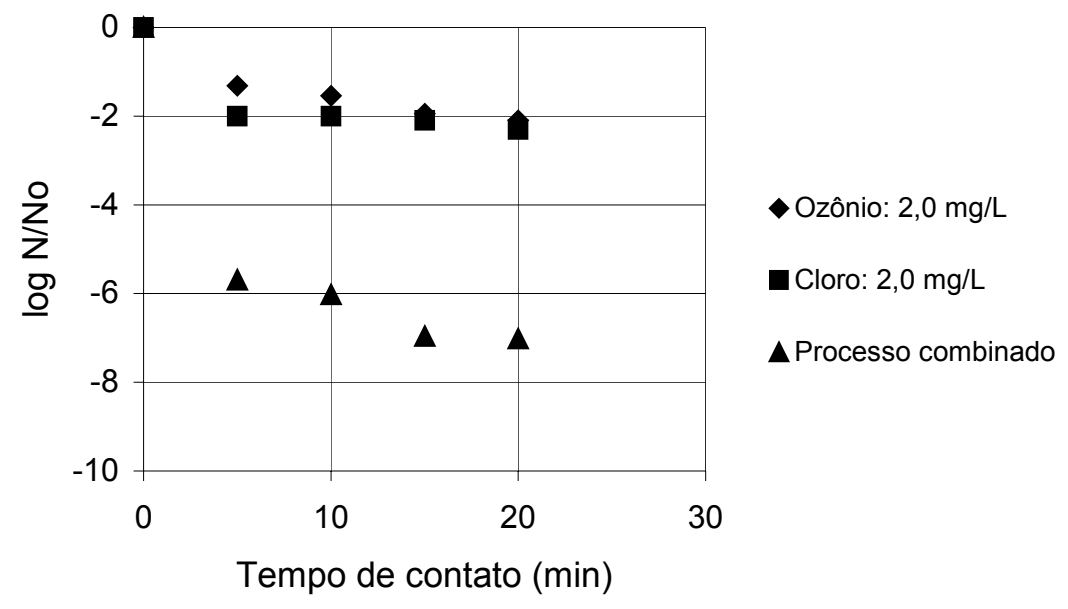

Figura 5.35 - Inativação de E. coli com os processos individuais, ozônio 2,0 $\mathrm{mg} / \mathrm{L}$, cloro $2,0 \mathrm{mg} / \mathrm{L}$ e com o processo combinado $2 \mathrm{O}_{3}+2 \mathrm{Cl}_{2} \mathrm{mg} / \mathrm{L}$.

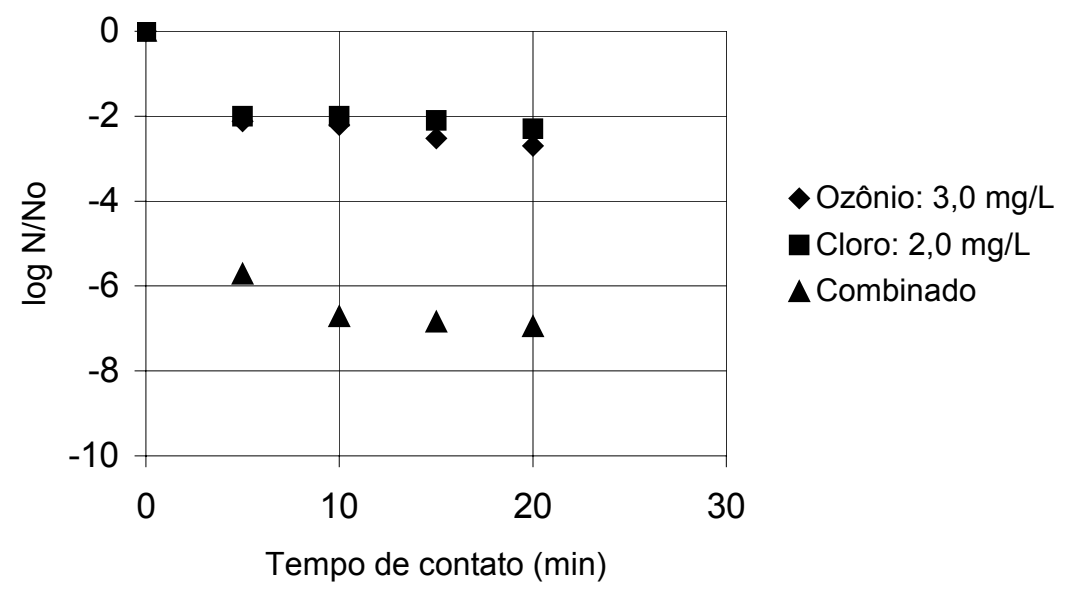

Figura 5.36 - Inativação de E. coli com os processos individuais, ozônio 3,0 $\mathrm{mg} / \mathrm{L}$, cloro $2,0 \mathrm{mg} / \mathrm{L}$ e com o processo combinado $3 \mathrm{O}_{3}+2 \mathrm{Cl}_{2} \mathrm{mg} / \mathrm{L}$. 


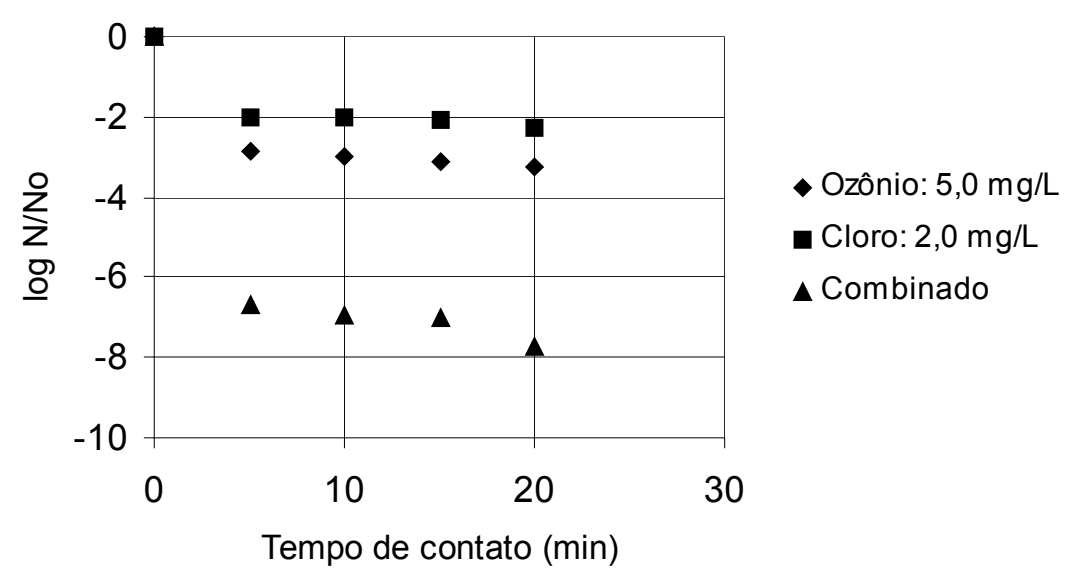

Figura 5.37 - Inativação de E. coli com os processos individuais, ozônio 5,0 $\mathrm{mg} / \mathrm{L}$, cloro $2,0 \mathrm{mg} / \mathrm{L}$ e com o processo combinado $5 \mathrm{O}_{3}+2 \mathrm{Cl}_{2} \mathrm{mg} / \mathrm{L}$.

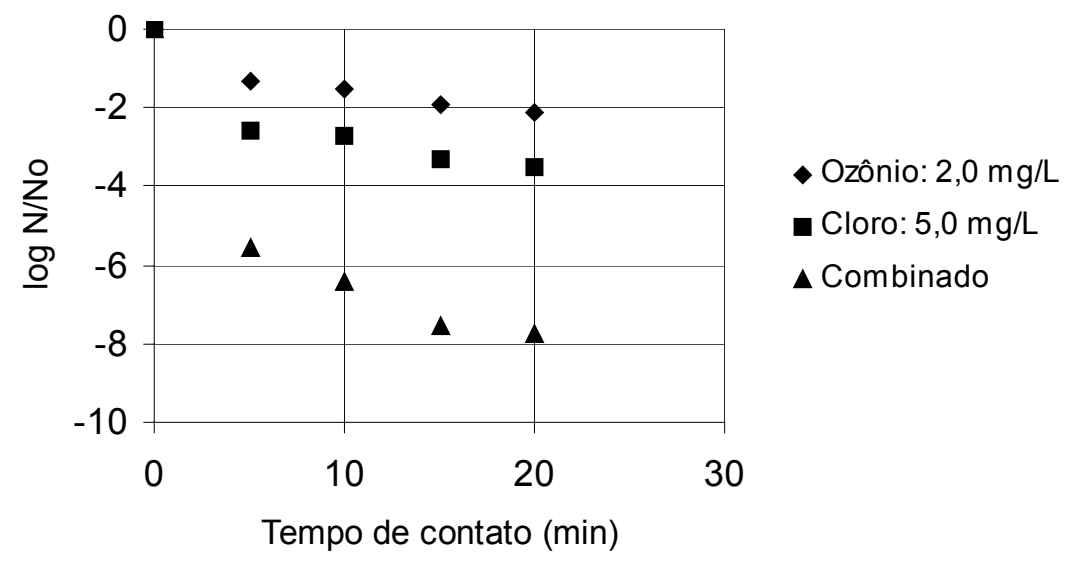

Figura 5.38 - Inativação de E. coli com os processos individuais, ozônio 2,0 $\mathrm{mg} / \mathrm{L}$, cloro $5,0 \mathrm{mg} / \mathrm{L}$ e com o processo combinado $2 \mathrm{O}_{3}+5 \mathrm{Cl}_{2} \mathrm{mg} / \mathrm{L}$.

Com os resultados de inativação de colifagos obtidos experimentalmente e sumarizados na Tabela 2 foram construídas as Figuras 5.39 a 5.42. 


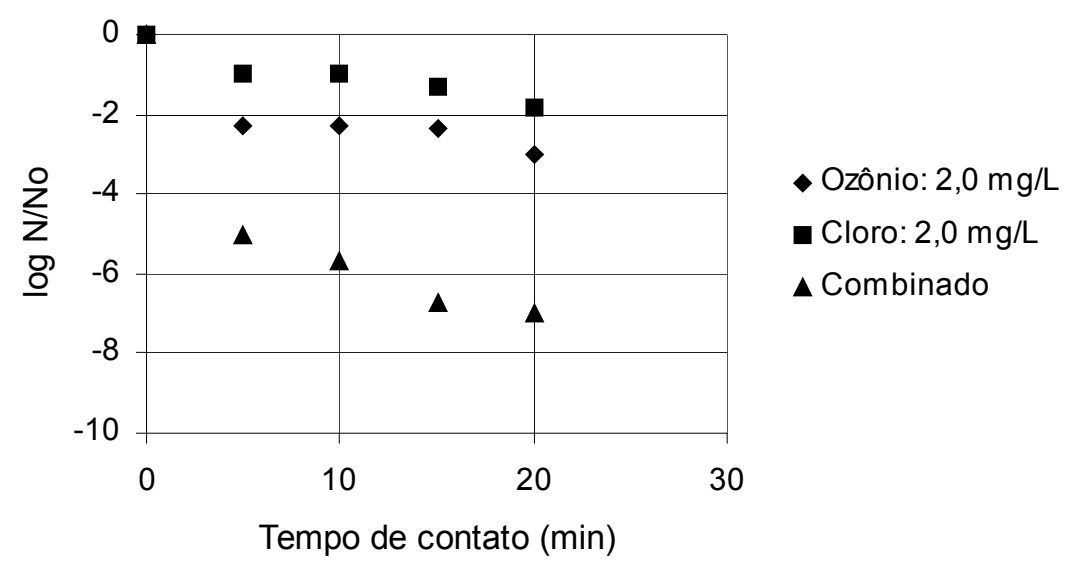

Figura 5.39 - Inativação de colifagos com os processos individuais, ozônio 2,0 $\mathrm{mg} / \mathrm{L}$, cloro $2,0 \mathrm{mg} / \mathrm{L}$ e com o processo combinado $2 \mathrm{O}_{3}+2 \mathrm{Cl}_{2} \mathrm{mg} / \mathrm{L}$.

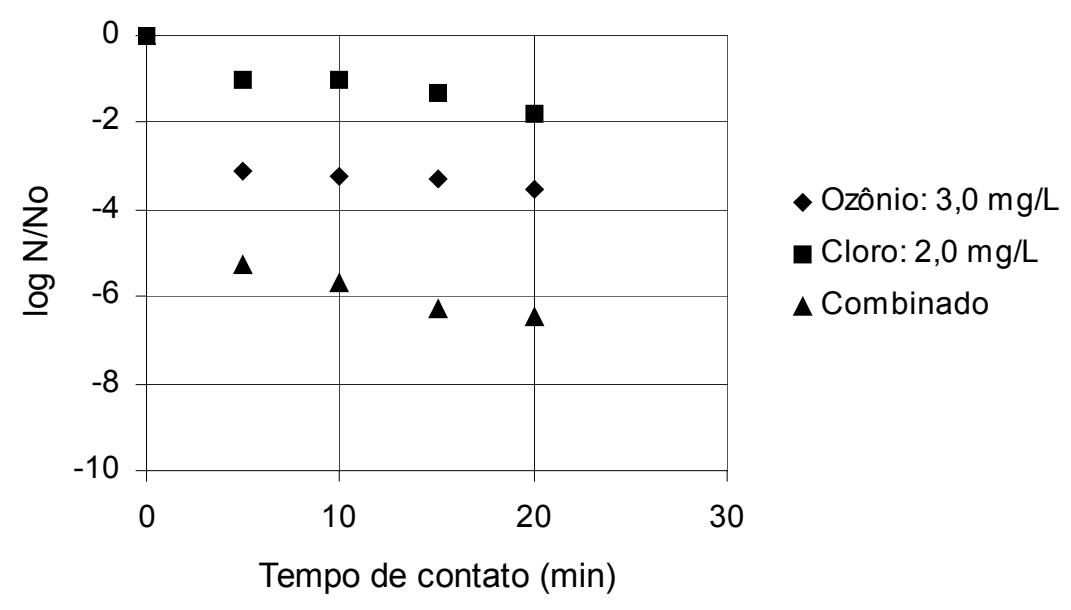

Figura 5.40 - Inativação de colifagos com os processos individuais, ozônio 3,0 $\mathrm{mg} / \mathrm{L}$, cloro $2,0 \mathrm{mg} / \mathrm{L}$ e com o processo combinado $3 \mathrm{O}_{3}+2 \mathrm{Cl}_{2} \mathrm{mg} / \mathrm{L}$. 


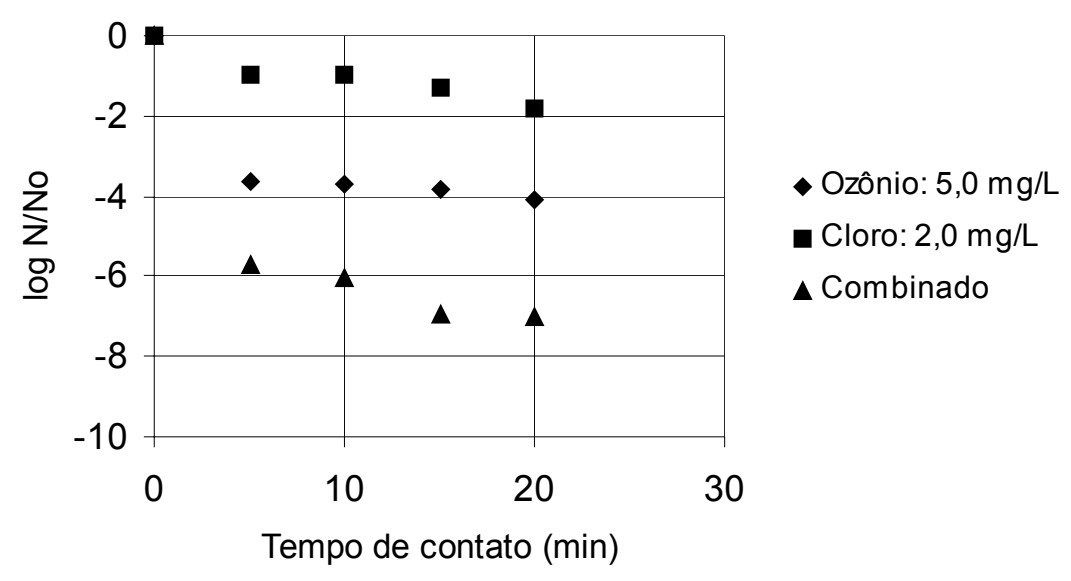

Figura 5.41 - Inativação de colifagos com os processos individuais, ozônio 5,0 $\mathrm{mg} / \mathrm{L}$, cloro $2,0 \mathrm{mg} / \mathrm{L}$ e com o processo combinado $5 \mathrm{O}_{3}+2 \mathrm{Cl}_{2} \mathrm{mg} / \mathrm{L}$.

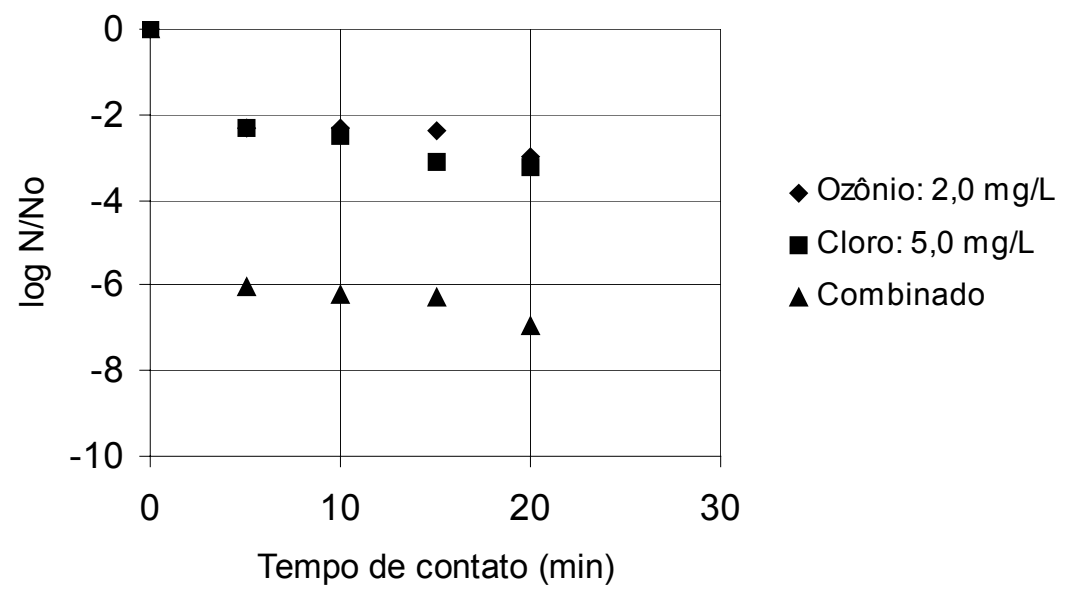

Figura 5.42 - Inativação de colifagos com os processos individuais, ozônio 2,0 $\mathrm{mg} / \mathrm{L}$, cloro $5,0 \mathrm{mg} / \mathrm{L}$ e com o processo combinado $2 \mathrm{O}_{3}+5 \mathrm{Cl}_{2} \mathrm{mg} / \mathrm{L}$.

Com os resultados de inativação de C. perfringens obtidos experimentalmente e sumarizados na Tabela 5.19 foram construidas as Figuras 5.43 a 5.46 . 


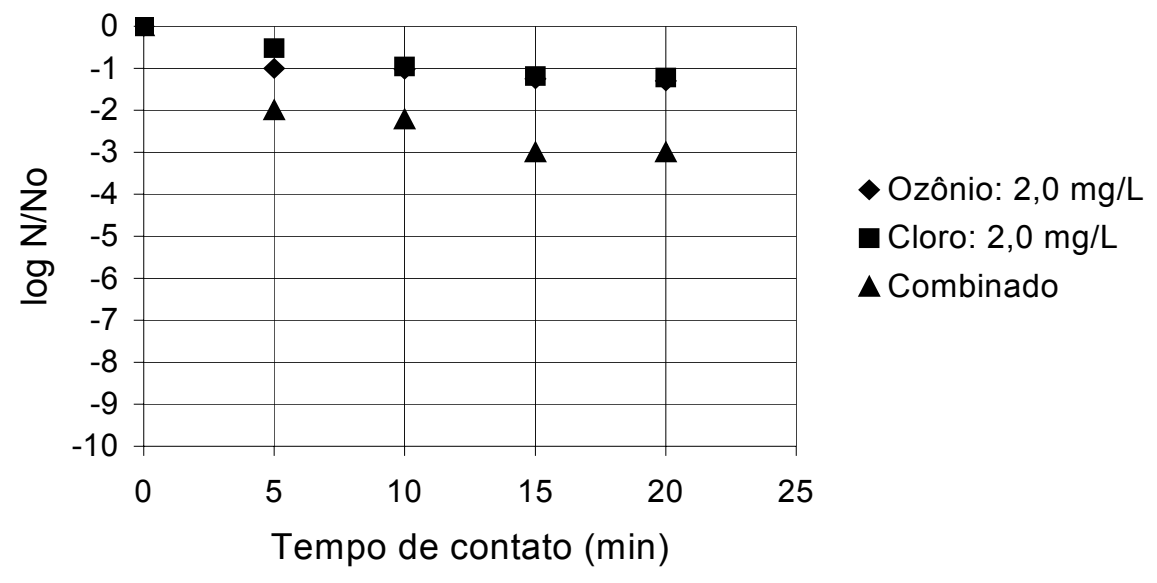

Figura 5.43 - Inativação de C. perfringens com os processos individuais, ozônio $2,0 \mathrm{mg} / \mathrm{L}$, cloro $2,0 \mathrm{mg} / \mathrm{L}$ e com o processo combinado $2 \mathrm{O}_{3}+2 \mathrm{Cl}_{2}$ $\mathrm{mg} / \mathrm{L}$.

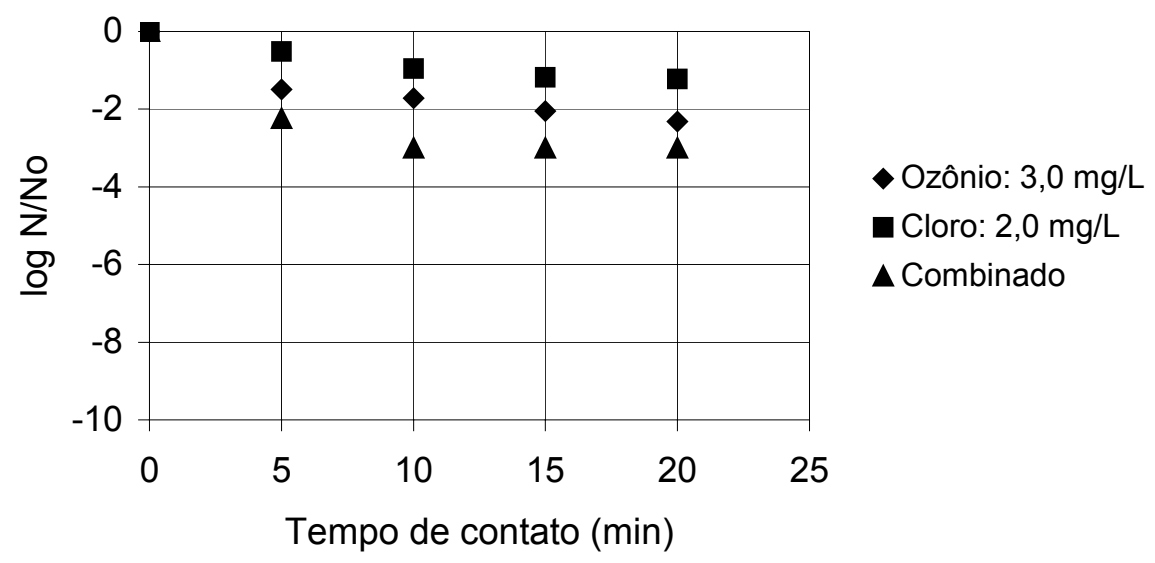

Figura 5.44 - Inativação de C. perfringens com os processos individuais, ozônio $3,0 \mathrm{mg} / \mathrm{L}$, cloro $2,0 \mathrm{mg} / \mathrm{L}$ e com o processo combinado $3 \mathrm{O}_{3}+2 \mathrm{Cl}_{2}$ $\mathrm{mg} / \mathrm{L}$. 


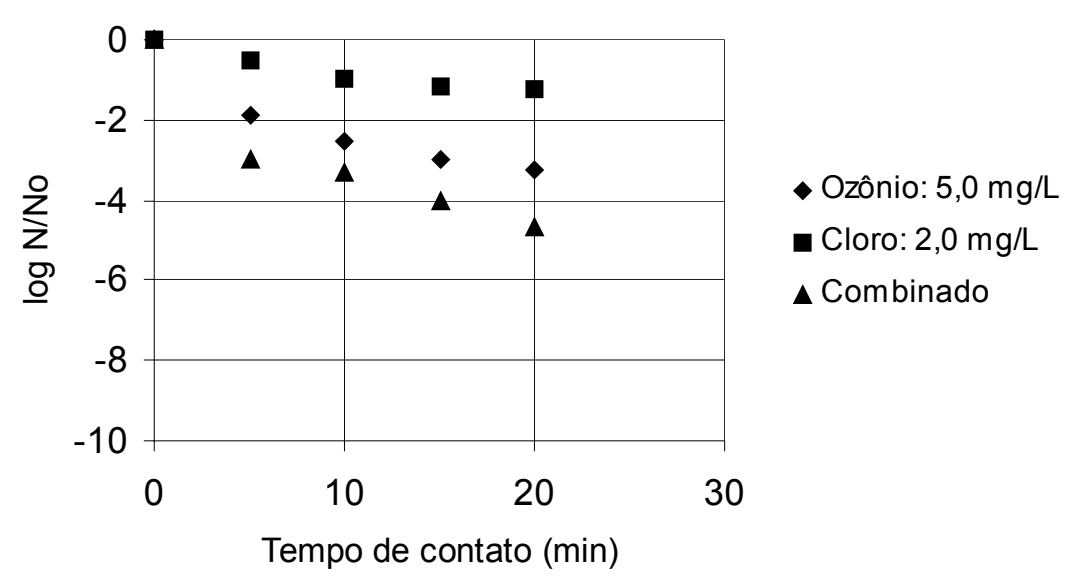

Figura 5.45 - Inativação de C. perfringens com os processos individuais, ozônio $5,0 \mathrm{mg} / \mathrm{L}$, cloro $2,0 \mathrm{mg} / \mathrm{L}$ e com o processo combinado $5 \mathrm{O}_{3}+2 \mathrm{Cl}_{2}$ $\mathrm{mg} / \mathrm{L}$.

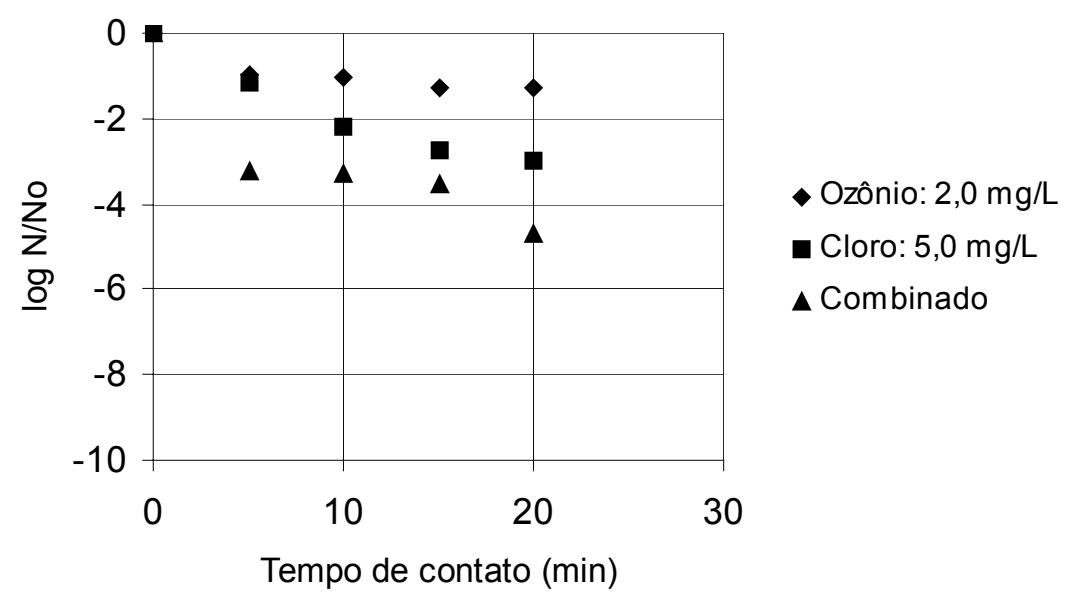

Figura 5.46 - Inativação de C. perfringens com os processos individuais, ozônio 2,0 mg/L, cloro 5,0 mg/L e com o processo combinado $2 \mathrm{O}_{3}+5 \mathrm{Cl}_{2}$ $\mathrm{mg} / \mathrm{L}$.

A partir das Figuras 5.35 a 5.46 constata-se de modo geral que:

$\mathrm{Na}$ etapa da desinfecção seqüencial, para todas as dosagens testadas e tempos de contato empregados, as inativações de E. coli, colifagos e $C$. perfringens foram substancialmente superiores para os processos combinados 
do que as inativações obtidas para as etapas com ozônio e cloro individuais. Vale ressaltar que foi empregada a mesma água de estudo bruta para os processos individuais e para a etapa seqüencial.

A similaridade dos resultados obtidos na etapa de desinfecção seqüencial, em que algumas vezes se trabalhou com maiores doses aplicadas do desinfetante primário $\left(\mathrm{O}_{3}\right)$, e em outras, com maiores doses aplicadas do desinfetante secundário $\left(\mathrm{Cl}_{2}\right)$, permitiu especular que podem ocorrer permutas nas concentrações aplicadas de ozônio e cloro na desinfecção seqüencial, sem prejuízo da inativação final.

Ou seja, pode-se optar por aplicar maiores dosagens de ozônio, primariamente, com respectiva redução da quantidade de cloro a ser aplicado como desinfetante secundário, ou vice-versa.

Isso pode ser bastante interessante do ponto de vista prático, dependendo das características da água bruta e dos objetivos que se pretende com a desinfecção seqüencial. Seja a oxidação de compostos orgânicos, e provável minimização de subprodutos problemáticos, o controle de microrganismos mais resistentes ou manutenção de residual desinfetante.

Em relação à E. coli (Figuras 5.35 a 5.38), inativações da ordem de 1 a 3 log foram obtidas para os processos individuais, mesmo para as maiores dosagens de ozônio e de cloro aplicadas, inferiores as inativações da ordem de 5,54 a 7,76 log para a etapa seqüencial.

Verificou-se certa similaridade nos resultados de inativação de E. coli com os desinfetantes individuais ozônio e cloro, para as dosagens e tempos de contato empregados. Notou-se, entretanto que, de modo geral, a $E$. coli foi mais sensivel ao cloro que ao ozônio.

Em relação aos colifagos (Figuras 5.39 a 5.42), de maneira análoga ao ocorrido para a $E$. coli houve aumento significativo na inativação dos fagos com o processo combinado, para todas as dosagens testadas e tempos de contato empregados. Ocorreram inativações da ordem de 1 a 4,1 log nas etapas individuais, enquanto que para a desinfecção seqüencial foram obtidas inativações que variaram de 5,06 a 7,02 log. 
Como já observado anteriormente (item 5.3) os fagos foram mais 'sensiveis' ao ozônio do que ao cloro.

Em relação à bactéria esporulada C. perfringens (Figuras 5.43 a 5.46), ocorreu maiores inativações na etapa da desinfecção seqüencial, em relação as etapas individuais. Enquanto inativações da ordem de 0,52 a 3,0 log ocorreram para as etapas individuais, para a desinfecção seqüencial as inativações de $C$. perfringens variaram de 2 a 4,70 log.

Entretanto, para essa bactéria, as inativações com o processo seqüencial ocorreram em menor grau do que as inativações verificadas para E. coli e colifagos.

Constatou-se que após ter atingido determinado nível de inativação, ocorrido nas etapas de desinfecção individuais, a população remanescente de C. perfringens ficava estável e não se verificava mais significativa melhoria nos resultados de inativação, durante a etapa seqüencial. Ao que parece, esse comportamento é característico dessa bactéria, uma vez que ele foi muito freqüente durante todas as etapas da pesquisa.

O efetivo incremento de inativação que ocorre para alguns microrganismos, proporcionado por processos de desinfecção combinados, é reconhecido na literatura como sinergismo.

\subsection{1 - Verificação de Sinergismo}

De acordo com a USEPA (1999), estudos de desinfecção interativa simultânea ou seqüencial - têm apresentado resultados promissores a respeito do efeito de sinergismo que pode vir ocorrer, quando se emprega esse tipo de desinfecção. Entretanto, não são todos os estudos em que se observa sinergismo. Alguns estudos na literatura reportam também efeitos negativos (antagonismo) ou aditivos (interação nula).

De acordo com FINCH et al. (2000), verifica-se o sinergismo quando no processo da desinfecção combinada ou seqüencial, ocorre inativação (de determinado organismo) superior à soma das inativações obtidas nas etapas individuais. 
Baseado nesse princípio foi realizada a somatória das inativações obtidas durante as etapas individuais e, juntamente com os resultados de inativação observados para o processo combinado, foi calculado o sinergismo para cada dosagem e tempo de contato previamente definidos (Tabela 5.20).

De acordo com os valores numéricos obtidos, e apresentados na Tabela 5.20, ocorreu sinergismo para a E. coli e para os fagos, na etapa da desinfecção seqüencial ozônio/ cloro, para as dosagens e tempos de contato empregados.

Também para a bactéria esporulada C. perfringens, para algumas dosagens e tempos de contato empregados, verificou-se sinergismo, embora em menor grau do que o ocorrido para os dois microrganismos anteriores. Para determinados tempos de contato e doses combinadas ocorreu antagonismo, representado pelos valores negativos na Tabela 5.20. Ou seja, a inativação resultante devido à desinfecção combinada foi menor que a somatória das inativações devido às etapas individuais com ozônio e cloro.

Um dos primeiros estudos a reportar o sinergismo na desinfecção foi o de KOUAME \& HAAS (1991) que modificaram o modelo matemático proposto por BERENBAUM (1981 e 1985). Os autores verificaram sinergismo na ação combinada dos agentes químicos monocloramina e cloro livre (aplicação simultânea) para a inativação de E. coli (ATCC 11229).

Para as mesmas dosagens e tempos de contato, a inativação de E. coli devido a aplicação simultânea de cloro livre e monocloramina foi substancialmente maior do que a soma das inativações devido ao cloro livre e monocloramina aplicados individualmente.

Para explicar o ocorrido com a E. coli, KOUAME \& HAAS (1991) recorreram ao trabalho de CAMPER \& McFETERS (1979) que demonstrava como o cloro livre era capaz de causar dano subletal em bactérias coliformes. Essa foi a explicação dada para os resultados de sinergismo observados pelos autores, que concluíram que o dano sub-letal provocado na bactéria coliforme por um desinfetante, melhorava sua sensibilidade a outro desinfetante, e então o sinergismo ocorria.

Também para os colifagos, de maneira semelhante ao ocorrido com a $E$. coli, elevado sinergismo foi observado na desinfecção seqüencial ozônio/ cloro, 
para todos os tempos de contato e doses combinadas empregados, embora seja citado no manual da USEPA (1999) que a inativação de colifagos MS2 parece ser menos eficiente com o uso dos desinfetantes combinados do que com o uso de desinfetantes individuais.

Sabe-se que a eficiência de inativação dos colifagos depende da cepa do vírus usada. A cepa do colifago MS2 é citada por vários autores na literatura, dentre eles LAZAROVA et al. (1998) como sendo muito resistente à desinfecção.

Os fagos empregados na pesquisa foram isolados de esgoto sanitário, os mesmos eram hospedados pela cepa de E. coli CIP 55.30, entretanto, não foi realizado estudo de identificação desses vírus.

Tem-se verificado, porém, em estudos de desinfecção realizados no Departamento de Hidráulica e Saneamento [SOUZA (2000), COLETTI (2003), SARTORI (2004), FERREIRA (2005)] que os colifagos isolados de esgoto sanitário e hospedados pela E. coli CIP 55.30 apresentam características de resistência similares à $E$. coli ao se empregar diferentes desinfetantes como cloro, ozônio, radiação UV, ácido peracético e dióxido de titânio.

Aliás, quando o desinfetante empregado foi o ozônio verificou-se ligeira superioridade de inativação dos colifagos em relação à E. coli.

Em relação à bactéria esporulada $C$. perfringens para alguns resultados não ocorreu sinergismo.

Também, FINCH et al. (2000) não observou sinergismo para a bactéria esporulada aeróbia Bacillus cereus, ao se realizar desinfecção com os processos combinados ozônio/ cloro livre e dióxido de cloro/ cloro livre, apesar do Bacillus cereus ter sido susceptivel aos desinfetantes individualmente. Os autores especularam que a falta de sinergismo pode ter sido devido a diferenças bioquímicas inerentes à estrutura das membranas dessa bactéria.

Foram compilados pela USEPA (1999) resultados de desinfecção interativa para alguns organismos, de reconhecido interesse no tratamento de água:

- a inativação de bactérias coliformes, cistos de Giardia, oocistos de Cryptosporidium e poliovírus tipo 1 parece aumentar com os desinfetantes combinados; 
- a inativação do vírus da Hepatite A e colifago MS2 parece ser menos eficiente com os processos combinados do que com os desinfetantes individuais;

- a inativação de esporos parece ser neutra.

\subsection{2 - Uso de sinergismo em critérios de projeto}

Vários estudos sugerem que pode haver vantagens na combinação de agentes químicos ou no uso seqüencial dos mesmos para determinadas finalidades em escala real, como por exemplo, a adição de menores quantidades de produtos químicos, a minimização da formação de subprodutos da desinfecção e, principalmente, o ocntrole de microrganismos de difícil inativação como Cryptosporidium e Giardia.

Entretanto, para que o conceito de sinergismos, associado ao processo combinado ou seqüencial, venha a ser aplicado futuramente em critérios de projeto, algumas barreiras deverão ser transpostas, especialmente o entendimento dos mecanismos de inativação envolvidos e o valor CT requerido.

FINCH et al. (2000) admitem que o sinergismo ainda é um fenômeno pouco compreendido no que concerne aos mecanismos de inativação envolvidos durante o processo, e não pode ser universalmente aplicável, ou seja, não se verifica sinergismo para todos os microrganismos. Assim, para as agências regulamentadoras de abastecimento de água, o sinergismo ainda é considerado algo "mágico".

Os mesmos autores relembram, entretanto, o quanto demorou para que o conceito CT - hoje considerado uma grande conquista dentro dos sofisticados projetos de desinfecção - pudesse ser aplicado. Cerca de 80 anos se passaram, desde os trabalhos de CHICK (1908) e WATSON (1908), até que o conceito CT pudesse tornar-se padrão para projetos de desinfecção, Safe Drinking Water Committee (1980).

Também para KOUAME \& HAAS (1991) na etapa de verificação dos efeitos produzidos pelos desinfetantes combinados (sinergismo, antagonismo ou efeito aditivo), o método usado não esclarece o mecanismo pelo qual o efeito 
observado é produzido, uma vez que o método é quantitativo, e permite ao investigador apenas relacionar a dose aplicada à magnitude da resposta (ou efeito). Assim, a resposta pode ser de sinergismo ou antagonismo, em relação à referência, sendo que a referência é o efeito aditivo. Conseqüentemente o método não é um modelo matemático da ação dos desinfetantes combinados sobre os microrganismos.

Para USEPA (1999) a desinfecção interativa é considerada tecnologia emergente. Assim, os créditos CT para a desinfecção interativa ainda não foram estabelecidos. 


\section{6 - CONCLUSÕES}

Com base nos resultados obtidos com a realização dos ensaios de desinfecção empregando cloro, ácido peracético, ozônio e o processo combinado na inativação de E. coli, colifagos e C. perfringens é possível concluir que:

- Para as condições empregadas nessa pesquisa, em que se utilizou água com elevada concentração de matéria orgânica, comparada à água potável, o cloro livre adicionado à água de estudo foi rapidamente transformado em formas de cloro combinado, o que resultou em pequena inativação dos microrganismos $E$. coli, colifagos e $C$. perfringens.

- Verificaram-se elevados valores de COD e absorbância UV-254 nm para a água de estudo bruta, para todos os ensaios de desinfecção, devido aos meios de cultura e substância húmica adicionados durante o preparo da água.

- Após a cloração os valores desses parâmetros aumentaram. Esse aumento foi atribuído à oxidação da matéria orgânica particulada e subseqüente diminuição do tamanho das partículas, as quais eram mais facilmente detectadas nas análises de COD.

- Inativações mais elevadas de E. coli e C. perfringens foram obtidas para a água de estudo preparada sem os meios de cultura, além de ter sido verificada considerável redução no consumo de cloro durante os ensaios de desinfecção com a água isenta dos meios de cultura.

- Os colifagos não foram detectados nos experimentos em que se empregou água de estudo sem os meios de cultura. Os fagos são vírus, o 
que impossibilitou o procedimento padrão de separação de células dos meios de cultura como ocorreu para as bactérias $E$. coli e $C$. perfringens.

- Para as análises de THMs realizadas, o clorofórmio foi o composto predominantemente detectado nas amostras de água clorada para as concentrações de cloro aplicadas de 2,0; 3,0; 4,0 e 5,0 mg/L. Ocorreu aumento na concentração de clorofórmio no decorrer do tempo de 1 a 6 dias, e após esse tempo, sua concentração diminuiu até tender a zero no trigésimo dia de monitoramento.

- Para as condições utilizadas nessa pesquisa, seja de concentração dos desinfetantes, tempos de contato, características da água de estudo, microrganismos indicadores empregados, etc, o ácido peracético foi mais efetivo que o hipoclorito de sódio na inativação dos três microrganismos estudados.

- A característica de cor da água (baixa ou elevada) teve pouca interferência na eficiência de inativação de $E$. coli, colifagos e $C$. perfringens com ácido peracético.

- Nos ensaios de desinfecção com ácido peracético, a presença da matéria orgânica na forma de extrato de levedura (meios de cultura), não interferiu na efetividade de desinfecção como ocorreu com o cloro.

- Após os tempos de contato empregados nos ensaios de desinfecção com ácido peracético ainda se detectavam residuais do desinfetante nas amostras de água.

- Os valores dos parâmetros COD e absorbância UV-254 nm aumentaram após a desinfecção com ácido peracético. Esse aumento foi devido à presença de ácido acético (produto da decomposição do ácido peracético) o qual contém carbono orgânico em sua estrutura química. 
- As taxas de inativação dos microrganismos indicadores com ozônio foram similares para as duas águas de estudo empregadas, com cor baixa e com cor elevada, denotando pouca influência da cor sobre a efetividade da ozonização.

- Para a água de estudo com cor elevada a resistência de inativação dos microrganismos indicadores ao ozônio seguiu a ordem: colifagos, E. coli e C. perfringens, o que confirma alguns resultados de estudos reportados na literatura que apresentam o ozônio como melhor agente virucida que bactericida.

- Em geral, para todas as dosagens de ozônio aplicadas e tempos de contato empregados, inativações de C. perfringens da ordem de 1 a $2 \log$ foram obtidas. Os valores de $\mathrm{Ct}$ mais elevados que foram empregados não contribuíram para aumentar a porcentagem de inativação dessa bactéria. Sua população remanescente foi da ordem de $10^{5} \mathrm{NMP} / 100$ $\mathrm{mL}$.

- Para todas as dosagens e tempos de contato empregados, verificou-se considerável aumento nas concentrações de COD e absorbância UV-254 $\mathrm{nm}$ após ozonização. Tais resultados foram relacionados ao aumento do conteúdo orgânico biodegradável promovido pela ozonização.

- Na etapa de desinfecção seqüencial, para todas as dosagens e tempos de contato empregados, as inativações de E. coli, colifagos e C. perfringens foram substancialmente superiores do que as inativações obtidas nas etapas com ozônio e cloro individuais.

- Com os resultados obtidos durante a desinfecção seqüencial observouse a possível versatilidade quanto a opção da aplicação de dosagens maiores ou menores nas etapas da desinfecção primária ou secundária, dependendo dos objetivos propostos a priori para o tratamento, seja a 
oxidação de compostos orgânicos, e provável minimização de subprodutos da desinfecção, o controle de determinados microrganismos ou manutenção de residual desinfetante .

- Ocorreu sinergismo para a E. coli e para os fagos na etapa da desinfecção seqüencial ozônio/ cloro, para todas as dosagens e tempos de contato empregados na pesquisa.

- Para a bactéria esporulada C. perfringens verificou-se a ocorrência tanto de sinergismo quanto de antagonismo dependendo das dosagens e tempos de contato empregados no estudo. 


\section{7 - SUGESTÕES}

- Ao se trabalhar com água preparada em laboratório, na qual os microrganismos de interesse são adicionados, realizar a "lavagem" ou, a retirada dos meios de cultura das células. Tal procedimento é de suma importância para se evitar elevada demanda dos oxidantes químicos.

- Investigar os subprodutos da desinfecção com outros agentes desinfetantes, além do cloro, como os do ozônio e ácido peracético, por exemplo.

- Ao se trabalhar com processos combinados de desinfecção verificar a geração de subprodutos após cada desinfetante individual e após a etapa combinada.

- Estudar os mecanismos de inativação dos processos combinados.

- Verificar a desinfecção com diferentes métodos alternativos ao cloro, especialmente os processos combinados, para os parasitas Giardia e Cryptosporidium. 


\section{8 - REFERÊNCIAS BIBLIOGRÁFICAS}

ALASRI, A.; ROQUES, C.; MICHEL, G. (1992). Bactericidal properties of peracetic acid and hydrogen peroxide, alone and in combination, and formaldehyde against bacterial water strains. Canadian Journal Microbiological, v.38, p.635-41.

APHA - AMERICAN PUBLIC HEALTH ASSOCIATION (1995). Standard Methods For The Examination Of Water And Wastewater, 19 ed., Washington.

BAEZA, C.; DUCOSTE, J. (2004). A non-biological surrogate for sequential disinfection processes. Wat. Res., v.38, p. 3400-3410.

BALDRY, M.G.C.; FRENCH, M.S. (1989). Disinfection of sewage effluent whith peracetic acid. Water Science Technology , v.21, n.3, p.203-6.

BALDRY, M.G.C.; FRENCH, M.S. (1989). Activity of peracetic acid against sewage indicator organisms. Water Science Technology , v.21, n.6/8, p.1747-9.

BALDRY, M.G.C. (1982). The bactericidal, fungicidal and sporicidal properties of hydrogen peroxide and peracetic acid. Journal of Applied Bacteriology, v.54, p.417-23.

BALDRY, M.G.C.; CAVADORE, A.; FRENCH, M.S.; MASSA, G.; RODRIGUES, L.M.; SCHIRCH, P.F.T.; THREADGOLD, T.L. (1995). Effluent disinfection in warm climates with peracetic acid. Water Science Technology, v.31, n.5-6, p.161-4.

BERG, G. (1978). The indicator system. In: Indicators of viruses in water and food (ed. G. Berg), pp.1-13, Ann arbor Science Publishers, ann Arbor, MI.

BERG, G.; METCALF, T.G. (1978). Indicators of viruses in waters. In: Indicators of viruses in water and food (ed. G. Berg), pp.267-296, Ann arbor Science Publishers, ann Arbor, MI.

BENINI, B. D. S. (2003). Remoção de Substâncias Húmicas na Dupla Fïtração com Filtro Ascendente de Pedregulho. São Carlos. 147 p. Dissertação (Mestrado) Escola de Engenharia de São Carlos, Universidade de São Paulo.

BERENBAUM, M.C. (1985).The expected effect of a combination of agents: the general solution. J. theor. Biol., v. 114, p. 413-431.

BILOTTA, P. (2000). Estudo Comparativo da ação do Ozônio e Radiação Ultravioleta na Desinfecção de Esgoto Sanitário. São Carlos. 96 p. Dissertação (Mestrado) - Escola de Engenharia de São Carlos, Universidade de São Paulo. 
BLACK, J.G. (1999). Microbiologia - Fundamentos e Perspectivas. 4 ed. Rio de Janeiro, Editora Guanabara Koogan S.A. 829 p.

BLOCK, S.S. (2001). Disinfection, Sterilization and Preservation. 5 ed. Philadelphia, PA: Lippincott Willians \& Wilkins, 1481 p.

CAIRNS, W.L. (1995). UV technology for water supply treatment. Water Supply, v.13, n.3/4, p.211-4.

CAMPOS, J. R. \& PIZZIRANI, J. A. (1977). Desinfecção com radiação ultravioleta. In: 9o Congresso Brasileiro de Engenharia sanitária e Ambiental. Belo Horizionte, 19 p.

CERQUEIRA, D. A; HORTA, M. C. S. (1999) Coliformes fecais não existem. In: 20 $0^{\circ}$ Congresso Brasileiro de Engenharia Sanitária e Ambiental. Rio de janeiro, $5 \mathrm{p}$.

CETESB, 1990 (Companhia de Tecnologia de Saneamento Ambiental). Determinação de colifagos em amostras de água. Método de ensaio L5/225. 24 p. são Paulo, 1990.

CETESB, 1993 (Companhia de Tecnologia de Saneamento Ambiental). Clostridium perfringens - determinação de amostras de água pela técnica dos tubos múltiplos. Método de ensaio L5/213. 27 p. São Paulo, julho, 1993.

CHANG, C.N; MA, Y.S; ZING, F.F.(2001). Reducing the formation of disinfection by-products by pré-ozonation. Chemosfere, v.46, p.21-30.

COLETTI, F. J. (2003). Inativação de Microrganismos Indicadores Presentes em Efluentes Secundários de Esgoto Sanitário com Radiação Ultravioleta. São Carlos. 239p. Tese (Doutorado) - Escola de Engenharia de São Carlos. Universidade de São Paulo.

COHEN, M.L. (2001). Emerging infectious diseases. In: BLOCK, S.S. (2001). Disinfection, Sterilization and Preservation. 5 ed. Philadelphia, PA: Lippincott Willians \& Wilkins, Cap. 35, p.685-694.

DANIEL, L.A. (1989). Desinfecção de Efluentes de Esgoto Sanitário PréDecantado Empregando Radiação Ultravioleta. São Carlos. 124p. Dissertação (Mestrado) - Escola de Engenharia de São Carlos, Universidade de São Paulo.

DANIEL, L.A. (1993). Desinfecção de Esgotos com Radiação Ultravioleta: Fotorreativação e Obtenção de Parâmetros Cinéticos. São Carlos. 169 p. Tese (Doutorado) - Escola de Engenharia de São Carlos. Universidade de São Paulo.

DANIEL, L.A. (2001) - Processos de desinfecção e desinfetantes alternativos na produção de água potável, PROSAB, coord. Luiz Antonio Daniel, ABES, Rio de Janeiro, 139 p. 
DEETZ, T.R.; SMITH, E.R.; GOYAL, S.M.; GERBA, C.P.; VALLET, J.V.; TSAI, H.L.; DUPONT, H.L.; KESWICK, B.H. (1984). Occurrence of rota and enteroviruses in drinking and environmental waters in a developing nation. Wat. Res. V.18, p. 572577.

DEGUSSA, (2003). Degussa Brasil Ltda. Peroxygen Chemicals, Bleaching \& Water Chemicals - II Encontro sobre aplicações Ambientais de Processos Oxidativos Avançados, 25 a 27 de agosto de 2003. Campinas, SP.

DIAS, V.D. (2001). Radiação Ultravioleta e Ozônio Aplicados como Métodos Alternativos de Desinfecção de Efluentes Secundários de Esgoto Sanitário. São Carlos. 150 p. Dissertação (Mestrado) - Escola de Engenharia de São Carlos, Universidade de São Paulo.

DRIEDGER, A.M.; RENNECKER, J.L.; MARIÑAS, B.J. (2000) Sequential inativation of Cryptosporidium parvum oocysts with ozone and free chlorine. Wat. Res., v.34, n.14, p. 3591-3597.

FERREIRA FILHO, S. S. (2001). Remoção de compostos orgânicos precursores de subprodutos da desinfecção e seu impacto na formação de trihalometanos em águas de abastecimento. Engenharia Sanitária e Ambiental, v. 6, n. 1, p.5360.

FERREIRA, I. V. L. (2005). Fotocatálise heterogênea com $\mathrm{TiO}_{2}$ aplicada ao tratamento de esgoto sanitário secundário. São Carlos, 158 p. Tese (Doutorado) - Escola de Engenharia de São Carlos, Universidade de São Paulo.

FINCH, G.R.; LIYANAGE, L.R.J.; GYURÉK, L.L.; BRADBURY, J.S. (2000). Synergistic Effects of Multiple Disinfectants. AWWA Research Foundation and American Water Wrks Association, USA. ISBN 1-58321-053-9. p.51.

FRANCO, R.M.B (2004). Métodos para medida de infectividade e inativação de Cryptosporidium spp. In: I Seminário Internacional em Protozoários Patogênicos Emergentes; II Congresso da Sociedade Paulista de Parasitologia: Meio Ambiente, Saneamento e Impactos na Saúde, 3 a 5 de novembro de 2004. Campinas, SP.

GASI, T.M.T.; SAMPAIO, A.O.; PACHECO, C.E.M.; CAMACHO, P.R.R.; ANDRADE, E.M. (1995). Aplicação de ácido peracético para desinfecção de efluentes de lodos ativados. In: $18^{\circ}$ Congresso Brasileiro de Engenharia Sanitária e Ambiental, Salvador.

HAAS, C.N.; CROCKETT, C.S; ROSE, J.B.; GERBA, C.P.; FAZIL, A.M. (1996). Assessing the risk posed by oocysts in drinking water. Jour. AWWA, september 1996, p. 131-136.

HACHICH, E.M. (2004). Ocorrência de Giardia e Cryptosporidium em águas superficiais no Estado de São Paulo. In: I Seminário Internacional em Protozoários Patogênicos Emergentes; II Congresso da Sociedade Paulista de 
Parasitologia: Meio Ambiente, Saneamento e Impactos na Saúde, 3 a 5 de novembro de 2004. Campinas, SP.

HAUTMAN, D.P.; MUNCH, D.J. (1997). Development of U.S.EPA method 551.1. Journal of Chromatographic Science, v.35, p. 221-231.

HELLER, L. (2004). Tratamento de águas de abastecimento e remoção de (oo)cistos de Giardia e Cryptosporidium. In: I Seminário Internacional em Protozoários Patogênicos Emergentes; II Congresso da Sociedade Paulista de Parasitologia: Meio Ambiente, Saneamento e Impactos na Saúde, 3 a 5 de novembro de 2004. Campinas, SP.

ISAAC, R.L. (2004). Remoção de Cryptosporidium e Giardia. In: I Seminário Internacional em Protozoários Patogênicos Emergentes; II Congresso da Sociedade Paulista de Parasitologia: Meio Ambiente, Saneamento e Impactos na Saúde, 3 a 5 de novembro de 2004. Campinas, SP.

JOLIVERT-GOUGEON, A.; BRAUX, A.S.; SAVAUGER, F.; ARTURO-SCHAAN, M.; CORMIER,, M. (1995). Influence of peracetic acid on Escherichia coli H10407 strain in laboratory microcosms. Canadian Journal of Microbiological, v.42, p.60-5.

KITIS, M.. (2003). Disinfection of wastewater whith peracetic acid: a review. Environment International. Disponivel online www.sciencedirect.com.

KIM, S.J.; OH, K.H.; LEE, S.H.; CHOI, S.S.; LEE, K.C. (1997). Study on secondary reaction and fate of hazardous chemicals by oxidants. Wat. Sci. Tech., v. 36, n.12, p. 325-331.

KOTT, Y.; ROZE, N.; SPERBER, S.; BETZER, N. (1974). Bacteriophages as viral pollution indicators. Wat. Res. V.8, p. 165-171.

KOUAME, Y.; HAAS, C.N. (1991). Inactivation of E. coli by combined action of free chlorine and monochloramine. Wat. Res. V.25, n.9, p.1027-1032.

LANGLAIS, B.; RECKHOW, D.A.; BRINK, D.R. (1991). Ozone in Water Treatment. Application and Engineering. Lewis Publishers Inc, Chelsea.

LASOBRAS, J.; MUNIESA, M.; FRÍAS, J.; LUCENA, F.; JOFRE, J. (1997). Relationship between the morphology of bacteriophages and their persistence in the environment. Wat. Sci.Tech., v. 35, n.11-12, p. 129-132.

LEHMANN, R.H. (2001). Synergism in Disinfectant Formulation. In: BLOCK, S.S. (2001). Disinfection, Sterilization and Preservation. 5 ed. Philadelphia, PA: Lippincott Willians \& Wilkins, Cap. 22, p.459-472.

MONARCA, S.; FERETTI, D.; COLLIVIGNARELLI, C.; GUZZELLA, L.; ZERBINI, I.; BERTANZA, G.; PEDRAZZANI, R. (2000). The influence of different 
disinfectants on mutagenicity and toxicity of urban wastewater. Wat. Res. V.34, n. 17, p. 4261-4269.

MONARCA, S.; ZANI, C.; RICHARDSON, S.D.; THRUSTON, A.D.; MORETTI, M.; FERETTI, D.; VILLARINI, M. (2004). Wat. Res., v. 38, p. 3809-3819.

M.S (Ministério da saúde), 2004. Portaria no 518, de 25 de março de 2004. Estabelece os procedimentos e responsabilidades relativos ao controle e vigilância da qualidade da água para consumo humano e seu padrão de potabilidade, e dá outras providências.

MUTTAMARA, S.; SALES, C.I.; GAZALI, Z. (1995). The formation of trihalomethane from chemical disinfectants and humic substances in drinking water. Water Supply, v.13, n.2, p.105-17.

OXENFORD, J.L. (1996). Disinfection by-products: current practices and future directions. In: MINEAR, R.A.; AMY, G.L. (1996). Disinfection byproducts in water treatment: the chemistry of their formation and control. Lewis Publishers Inc, Cap.1, p.3.

PAYMENT, P.; FRANCO, E. (1993). Clostridium perfringens and somatic coliphages as indicators of the efficiency of drinking water treatment for viruses and protozoan cysts. Appl. Environ. Microbiol., v. 59, n. 8, p. 24182424.

PELCZAR, M.; REID, R.; CHAN, E.C.S. (1997). Microbiologia: Conceitos e Aplicações. São Paulo, Makron Books, 2. ed, v.2.

RAJALA-MUSTONEN, R. L.; TOIVOLA, P. S.; HEINONEN-TANSKI, H. (1997). Effects of peracetic acid and UV irradiation on the inactivation of coliphages in wastewater. Water Science Technology, v.35, n.11/12, p.237-41.

RICE, E.W.; FOX, K.R.; MILTNER, R.J.; LYTLE, D.A; JOHNSON, C.H. (1996). Evaluating plant performance with endospores. Jour. AWWA, v.88, n.9, p.122130.

RUSSELL, A.D.; MAILLARD, J.Y.; BEGGS, T.S.; DAY, M.J.; HUDSON, R.A. (1994). Effect of biocides on MS2 and K coliphages. Appl. Environ. Microbiol., v. 60, n. 6, p. 2205-2206.

SAMPAIO, A. O. (1985). Desinfecção de Esgotos Sanitários com Radiação Ultravioleta. São Carlos. 96 p. Dissertação (Mestrado) - Escola de Engenharia de São Carlos, Universidade de São Paulo.

SANCHEZ-RUIZ, C.; ROYANO, M. S.; MONZÓN, I. T. (1995). An evaluation of the efficiency and impact of raw wastewater disinfection with peracetic acid prior to ocean discharge. Water Science Technology, v.32, n.7, p.159-66. 
SARTORI, L. (2004). Adequação da Qualidade Microbiológica de Efluentes Secundários de Esgoto Sanitário pela Aplicação dos Desinfetantes Ozônio, Permanganato de Potássio e Ácido Peracético. São Carlos. 202 p. Tese (Doutorado) - Escola de Engenharia de São Carlos, Universidade de São Paulo.

SCHOENEN, D. (2002). Role of disinfection in suppressing the spread of pathogens with drinking water: possibilities and limitations. Wat. Res., v.36, p.3874-3888, Pergamon Press.

SCARPINO, P.V. (1978). Bacteriophage indicators. In: Indicators of viruses in water and food (ed. G. Berg), pp.201-227, Ann arbor Science Publishers, ann Arbor, MI.

SHANG, C.; BLATCHLEY, E. R. (2001). Chlorination of pure bacterial cultures in aqueous solution. Wat. Res., v. 35, n.1, p. 244-254, Pergamon Press.

SIMKOVA, A.; CERVENKA, J. (1981). Coliphages as ecological indicators of enteroviruses in various water systems. Bulletin of the World Health Organization, n.59, p. 611-618.

SINGER, P.C. (1999). Humic substances as precursors for potentially harmful disinfection by-products. Wat. Sci. Tech., v. 40, n. 9, p. 25-30.

SOUZA, J. B. (2000). Desinfecção de Águas com Cor e Turbidez Elevadas: Comparação Técnica de Processos Alternativos ao Cloro Empregando Radiação Ultravioleta e Ácido Peracético. São Carlos. 148 p. Dissertação (Mestrado) Escola de Engenharia de São Carlos, Universidade de São Paulo.

STETLER, R.E. (1984). Coliphages as indicators of enteroviruses. Appl. Environ. Microbiol, v. 48, n. 3, p. 668-670.

SZEWZYK, U., et al. (2000). Microbiological safety of drinking water. Annu. Rev. Microbiol., v.54, p.81-127.

TENG, H.; VEENSTRA, J. N. (1996). A study of disinfection by-products formed using four alternative disinfectants as a function of precursor characteristics. In: MINEAR, R.A.; AMY, G.L. (1996). Disinfection by-products in water treatment: the chemistry of their formation and control. Lewis Publishers Inc, Cap.18, p.371-392.

TRUSSELL, R.R. (1999). Safeguarding distribution system integrity. Journal $A W W A$, v.91, n.1, p.46-54.

TYRREL, S.A.; RIPPEY, S.R.; WATKINS, W.D. (1995). Inactivation of bacterial and viral indicators in secondary sewage effluents, using chlorine and ozone. Wat. Res. V. 29, n.11, p. 2483-2490.

USEPA (U.S. Environmental Protection Agency) Guidance Manual - Alternative Disinfectants and Oxidants. (1999). Washington, D.C. Report n.815-R-99-014. 
UNITED STATES ENVIRONMENTAL PROTECTION AGENCY (2002). Federal Register: Proposed Rules, v.67, n.45, p.1057-58. Mar. Disponivel em: <http://www.epa.gov/Ogwdw000/standard/ucmr/aliomonas030702.pdf>. Acesso em: 18 jan. 2003.

VAUGHN, J.M.; METCALF, T.G. (1975). Coliphages as indicators of enteric viruses in shellfish and shellfish raising estuarine waters. Wat. Res. v.9, p. 613-616.

VENCZEL, L.V.; ARROWOOD, M.; HURD, M.; SOBSEY, M.D. (1997). Inactivation of Cryptosporidium parvum oocysts and Clostridium perfringens spores by a mixed-oxidant disinfectant and by free chlorine. Appl. Environ. Microbiol., v. 63, n. 4, p. 1598-1601.

VESCHETTI, E. et al. (2003). Pilot-plant comparative of peracetic acid and sodium hypochlorite wastewater disinfection. Wat. Res., v. 37, p. 78-94, Pergamon Press.

WHO, 2002 (World Health Organization). Water Quality - Guidelines, Standards and Health: Assessment of Risk and Management for Water-Related Infectious Disease. File://A: $\backslash$ Water Quality - Guidelines, Standards and Health Assesment. Htm

WHO, 2003 (World Health Organization). Emerging issues in water and infectious disease, 20 p., Geneva, Switzerland. ISBN 9-241-59082-3.

WEINBERG, H.S.; GLAZE, W.H. (1996). An overview of ozonation disinfection by-products. In: MINEAR, R.A.; AMY, G.L. (1996). Disinfection by-products in water treatment: the chemistry of their formation and control. Lewis Publishers Inc, Cap.7, p.165-186.

WICKRAMANAYAKE, G.B.; RUBIN, A.J.; SPROUL, O.J. (1984). Inactivation of Giardia lamblia cysts with ozone. Appl. Environ. Microbiol., v.48., n.3, p. 671-672.

WILLIAMS, D.T.; LeBEL, G.L.; BENOIT, F.M. (1997). Disinfection by-products in Canadian drinking water. Chemosphere, v.34, n.2, p. 299-316.

ZARPELON, A.; RODRIGUES, E.M. (2002). Os trihalometanos na água de consumo humano. Sanare. Revista Técnica da Sanepar, v.17, n.17, p. 20-30. 


\section{ANEXOS}

TABELA A 01- Características da água de estudo bruta (cor baixa) e das amostras após a desinfecção com cloro aplicado em concentração de 2,0 mg/L.

\begin{tabular}{|c|c|c|c|c|}
\hline Parâmetros & \multicolumn{4}{|c|}{ Água de estudo } \\
\hline $\mathrm{pH}$ & \multicolumn{4}{|c|}{7,6} \\
\hline Alcalinidade $\left(\mathrm{mg} / \mathrm{L} \mathrm{CaCO}_{3}\right)$ & \multicolumn{4}{|c|}{87,82} \\
\hline Temperatura $\left({ }^{\circ} \mathrm{C}\right)$ & \multicolumn{4}{|c|}{23} \\
\hline Abs (254 nm) & \multicolumn{4}{|c|}{0,026} \\
\hline $\mathrm{COT}(\mathrm{mg} / \mathrm{L})$ & \multicolumn{4}{|c|}{5,632} \\
\hline Cor verdadeira $(\mathrm{uC})$ & \multicolumn{4}{|c|}{4,0} \\
\hline Turbidez (uT) & \multicolumn{4}{|c|}{0,23} \\
\hline E. coli $(U F C / 100 \mathrm{~mL})$ & \multicolumn{4}{|c|}{$1,0 \times 10^{5}$} \\
\hline Colifagos (UFP/100 mL) & \multicolumn{4}{|c|}{$1,0 \times 10^{4}$} \\
\hline C. perfringens $((\mathrm{NMP} / 100 \mathrm{~mL})$ & \multicolumn{4}{|c|}{$4,0 \times 10^{7}$} \\
\hline & \multicolumn{4}{|c|}{ Cloro aplicado: $2,0 \mathrm{mg} / \mathrm{L}$} \\
\hline & \multicolumn{4}{|c|}{ Tempo de contato (min) } \\
\hline Parâmetros & 5,0 & 10,0 & 15,0 & 20,0 \\
\hline $\mathrm{pH}$ & 7,7 & 7,6 & 7,8 & 8,5 \\
\hline Alcalinidade $\left(\mathrm{mg} / \mathrm{LcaCO}_{3}\right)$ & 79,84 & 87,82 & 91,82 & 91,82 \\
\hline Temperatura $\left({ }^{\circ} \mathrm{C}\right)$ & 23 & 23 & 23 & 23 \\
\hline $\operatorname{Abs}(254 \mathrm{~nm})$ & 0,067 & 0,073 & 0,073 & 0,070 \\
\hline $\mathrm{COT}(\mathrm{mg} / \mathrm{L})$ & 10,96 & 11,33 & 9,434 & 10,17 \\
\hline Cloro residual livre $\left(\mathrm{mgCl}_{2} / \mathrm{L}\right)$ & 0,04 & 0,04 & 0,07 & 0,04 \\
\hline Cloro residual total $\left(\mathrm{mgCl}_{2} / \mathrm{L}\right)$ & 2,0 & 1,7 & 2,0 & 2,0 \\
\hline E. coli $(U F C / 100 \mathrm{~mL})$ & $>10^{3}$ & $>10^{3}$ & $>10^{3}$ & $>10^{3}$ \\
\hline Colifagos (UFP/100 mL) & $10^{3}$ & $10^{3}$ & $10^{3}$ & $10^{3}$ \\
\hline C. perfringens $((\mathrm{NMP} / 100 \mathrm{~mL})$ & $2,0 \times 10^{6}$ & $2,3 \times 10^{6}$ & $2,0 \times 10^{6}$ & $2,3 \times 10^{6}$ \\
\hline
\end{tabular}

TABELA A 02- Características da água de estudo bruta (cor baixa) e das amostras após a desinfecção com cloro aplicado em concentração de 3,0 mg/L.

\begin{tabular}{|c|c|c|c|c|}
\hline Parâmetros & \multicolumn{4}{|c|}{ Água de estudo } \\
\hline $\mathrm{pH}$ & \multicolumn{4}{|c|}{7,8} \\
\hline Alcalinidade $\left(\mathrm{mg} / \mathrm{L} \mathrm{CaCO}_{3}\right)$ & \multicolumn{4}{|c|}{79,84} \\
\hline Temperatura $\left({ }^{\circ} \mathrm{C}\right)$ & \multicolumn{4}{|c|}{23} \\
\hline Abs $(254 \mathrm{~nm})$ & \multicolumn{4}{|c|}{0,071} \\
\hline $\mathrm{COT}(\mathrm{mg} / \mathrm{L})$ & \multicolumn{4}{|c|}{8,186} \\
\hline Cor verdadeira $(\mathrm{uC})$ & \multicolumn{4}{|c|}{28} \\
\hline Turbidez (uT) & \multicolumn{4}{|c|}{0,54} \\
\hline E. coli $(U F C / 100 \mathrm{~mL})$ & \multicolumn{4}{|c|}{$1,0 \times 10^{7}$} \\
\hline Colifagos (UFP/100 mL) & \multicolumn{4}{|c|}{$1,0 \times 10^{5}$} \\
\hline C. perfringens $((\mathrm{NMP} / 100 \mathrm{~mL})$ & \multicolumn{4}{|c|}{$4,0 \times 10^{5}$} \\
\hline & \multicolumn{4}{|c|}{ Cloro aplicado: $3,0 \mathrm{mg} / \mathrm{L}$} \\
\hline & \multicolumn{4}{|c|}{ Tempo de contato (min) } \\
\hline Parâmetros & 5,0 & 10,0 & 15,0 & 20,0 \\
\hline $\mathrm{pH}$ & 8,5 & 8,4 & 8,4 & 8,4 \\
\hline Alcalinidade $\left(\mathrm{mg} / \mathrm{LcaCO}_{3}\right)$ & 103,79 & 91,82 & 91,82 & 87,82 \\
\hline Temperatura $\left({ }^{\circ} \mathrm{C}\right)$ & 23 & 23 & 23 & 23 \\
\hline Abs (254 nm) & 0,116 & 0,128 & 0,136 & 0,125 \\
\hline $\mathrm{COT}(\mathrm{mg} / \mathrm{L})$ & 5,700 & 9,762 & 6,908 & 11,28 \\
\hline Cloro residual livre $\left(\mathrm{mgCl}_{2} / \mathrm{L}\right)$ & 0,04 & 0,03 & 0,03 & 0,02 \\
\hline Cloro residual total $\left(\mathrm{mgCl}_{2} / \mathrm{L}\right)$ & 2,8 & 2,6 & 2,6 & 2,5 \\
\hline E. coli $(U F C / 100 \mathrm{~mL})$ & $9 \times 10^{5}$ & $4,5 \times 10^{5}$ & $5 \times 10^{3}$ & $3 \times 10^{3}$ \\
\hline Colifagos (UFP/100 mL) & $1 \times 10^{3}$ & $1,2 \times 10^{2}$ & $1 \times 10^{3}$ & $5 \times 10^{2}$ \\
\hline C. perfringens $((\mathrm{NMP} / 100 \mathrm{~mL})$ & $1,7 \times 10^{4}$ & $1,2 \times 10^{4}$ & $4,0 \times 10^{3}$ & $4,0 \times 10^{3}$ \\
\hline
\end{tabular}


TABELA A 03 - Características da água de estudo bruta (cor baixa) e das amostras após a desinfecção com cloro aplicado em concentração 4,0 mg/L.

\begin{tabular}{|c|c|c|c|c|}
\hline Parâmetros & \multicolumn{4}{|c|}{ Água de estudo } \\
\hline $\mathrm{pH}$ & \multicolumn{4}{|c|}{7,7} \\
\hline Alcalinidade $\left(\mathrm{mg} / \mathrm{L} \mathrm{CaCO}_{3}\right)$ & \multicolumn{4}{|c|}{79,84} \\
\hline Temperatura $\left({ }^{\circ} \mathrm{C}\right)$ & \multicolumn{4}{|c|}{23} \\
\hline Abs $(254 \mathrm{~nm})$ & \multicolumn{4}{|c|}{0,047} \\
\hline $\mathrm{COT}(\mathrm{mg} / \mathrm{L})$ & \multicolumn{4}{|c|}{23,66} \\
\hline Cor verdadeira $(\mathrm{uC})$ & \multicolumn{4}{|c|}{21} \\
\hline Turbidez (uT) & \multicolumn{4}{|c|}{0,69} \\
\hline E. coli $(U F C / 100 \mathrm{~mL})$ & \multicolumn{4}{|c|}{$4,0 \times 10^{6}$} \\
\hline Colifagos (UFP/100 mL) & \multicolumn{4}{|c|}{$1,0 \times 10^{5}$} \\
\hline C. perfringens $((\mathrm{NMP} / 100 \mathrm{~mL})$ & \multicolumn{4}{|c|}{$4,0 \times 10^{5}$} \\
\hline & \multicolumn{4}{|c|}{ Cloro aplicado: $4,0 \mathrm{mg} / \mathrm{L}$} \\
\hline & \multicolumn{4}{|c|}{ Tempo de contato (min) } \\
\hline Parâmetros & 5,0 & 10,0 & 15,0 & 20,0 \\
\hline $\mathrm{pH}$ & 8,4 & 8,2 & 8,6 & 8,4 \\
\hline Alcalinidade $\left(\mathrm{mg} / \mathrm{LcaCO}_{3}\right)$ & 95,81 & 83,83 & 91,82 & 95,81 \\
\hline Temperatura $\left({ }^{\circ} \mathrm{C}\right)$ & 23 & 23 & 23 & 23 \\
\hline Abs $(254 \mathrm{~nm})$ & 0,143 & 0,149 & 0,142 & 0,140 \\
\hline $\mathrm{COT}(\mathrm{mg} / \mathrm{L})$ & 25,59 & 25,60 & 26,16 & 26,02 \\
\hline Cloro residual livre $\left(\mathrm{mgCl}_{2} / \mathrm{L}\right)$ & 0,05 & 0,07 & 0,06 & 0,05 \\
\hline Cloro residual total $\left(\mathrm{mgCl}_{2} / \mathrm{L}\right)$ & 3,8 & 3,7 & 3,7 & 3,5 \\
\hline E. coli $(U F C / 100 \mathrm{~mL})$ & $7,4 \times 10^{5}$ & $1,0 \times 10^{4}$ & $2 \times 10^{3}$ & $5 \times 10^{4}$ \\
\hline Colifagos (UFP/100 mL) & $3,75 \times 10^{4}$ & $4,5 \times 10^{3}$ & $8,15 \times 10^{4}$ & $9,45 \times 10^{4}$ \\
\hline C. perfringens $((\mathrm{NMP} / 100 \mathrm{~mL})$ & $1,7 \times 10^{4}$ & $1,7 \times 10^{4}$ & $1,1 \times 10^{4}$ & $1,7 \times 10^{4}$ \\
\hline
\end{tabular}

TABELA A 04 - Características da água de estudo bruta (cor baixa) e das amostras após a desinfecção com cloro aplicado em concentração de 5,0 mg/L.

\begin{tabular}{|c|c|c|c|c|}
\hline Parâmetros & \multicolumn{4}{|c|}{ Água de estudo } \\
\hline $\mathrm{pH}$ & \multicolumn{4}{|c|}{7,2} \\
\hline Alcalinidade $\left(\mathrm{mg} / \mathrm{L} \mathrm{CaCO}_{3}\right)$ & \multicolumn{4}{|c|}{107,78} \\
\hline Temperatura $\left({ }^{\circ} \mathrm{C}\right)$ & \multicolumn{4}{|c|}{23} \\
\hline Abs $(254 \mathrm{~nm})$ & \multicolumn{4}{|c|}{0,027} \\
\hline $\mathrm{COT}(\mathrm{mg} / \mathrm{L})$ & \multicolumn{4}{|c|}{4,652} \\
\hline Cor verdadeira $(\mathrm{uC})$ & \multicolumn{4}{|c|}{19} \\
\hline Turbidez (uT) & \multicolumn{4}{|c|}{0,57} \\
\hline E. coli (UFC/ $100 \mathrm{~mL})$ & \multicolumn{4}{|c|}{$1,0 \times 10^{7}$} \\
\hline Colifagos (UFP/100 mL) & \multicolumn{4}{|c|}{$5,0 \times 10^{4}$} \\
\hline C. perfringens $((\mathrm{NMP} / 100 \mathrm{~mL})$ & \multicolumn{4}{|c|}{$1,6 \times 10^{6}$} \\
\hline & \multicolumn{4}{|c|}{ Cloro aplicado: $5,0 \mathrm{mg} / \mathrm{L}$} \\
\hline & \multicolumn{4}{|c|}{ Tempo de contato (min) } \\
\hline Parâmetros & $\mathbf{5 , 0}$ & $\mathbf{1 0 , 0}$ & 15,0 & 20,0 \\
\hline $\mathrm{pH}$ & 8,0 & 8,4 & 8,4 & 8,3 \\
\hline Alcalinidade $\left(\mathrm{mg} / \mathrm{LcaCO}_{3}\right)$ & 67,86 & 87,82 & 79,84 & 83,83 \\
\hline Temperatura $\left({ }^{\circ} \mathrm{C}\right)$ & 23 & 23 & 23 & 23 \\
\hline $\operatorname{Abs}(254 \mathrm{~nm})$ & 0,179 & 0,164 & 0,161 & 0,177 \\
\hline $\mathrm{COT}(\mathrm{mg} / \mathrm{L})$ & 7,160 & 5,105 & 6,208 & 6,200 \\
\hline Cloro residual livre $\left(\mathrm{mgCl}_{2} / \mathrm{L}\right)$ & 0,06 & 0,05 & 0,04 & 0,04 \\
\hline Cloro residual total $\left(\mathrm{mgCl}_{2} / \mathrm{L}\right)$ & 4,6 & 4,3 & 4,3 & 4,5 \\
\hline E. coli (UFC/ $100 \mathrm{~mL})$ & $1,0 \times 10^{5}$ & $1,0 \times 10^{5}$ & $1,4 \times 10^{5}$ & $7 \times 10^{5}$ \\
\hline Colifagos (UFP/100 mL) & $<1$ & $<1$ & $<1$ & $<<1$ \\
\hline C. perfringens $((\mathrm{NMP} / 100 \mathrm{~mL})$ & $1,6 \times 10^{6}$ & $2,8 \times 10^{5}$ & $1,4 \times 10^{5}$ & $1,4 \times 10^{5}$ \\
\hline
\end{tabular}


TABELA A 05 - Características da água de estudo bruta (cor elevada) e das amostras após a desinfecção com cloro aplicado em concentração de 2,0 mg/L .

\begin{tabular}{|c|c|c|c|c|}
\hline Parâmetros & \multicolumn{4}{|c|}{ Água de estudo } \\
\hline $\mathrm{pH}$ & \multicolumn{4}{|c|}{7,2} \\
\hline Alcalinidade $\left(\mathrm{mg} / \mathrm{L} \mathrm{CaCO}_{3}\right)$ & \multicolumn{4}{|c|}{123,75} \\
\hline Temperatura $\left({ }^{\circ} \mathrm{C}\right)$ & \multicolumn{4}{|c|}{23} \\
\hline Abs $(254 \mathrm{~nm})$ & \multicolumn{4}{|c|}{0,123} \\
\hline $\mathrm{COT}(\mathrm{mg} / \mathrm{L})$ & \multicolumn{4}{|c|}{32,31} \\
\hline Cor verdadeira $(\mathrm{uC})$ & \multicolumn{4}{|c|}{106} \\
\hline Turbidez (uT) & \multicolumn{4}{|c|}{0,57} \\
\hline E. coli $(U F C / 100 \mathrm{~mL})$ & \multicolumn{4}{|c|}{$1,0 \times 10^{7}$} \\
\hline Colifagos (UFP/100 mL) & \multicolumn{4}{|c|}{$1,0 \times 10^{5}$} \\
\hline C. perfringens $((\mathrm{NMP} / 100 \mathrm{~mL})$ & \multicolumn{4}{|c|}{$5 \times 10^{4}$} \\
\hline & \multicolumn{4}{|c|}{ Cloro aplicado: $2,0 \mathrm{mg} / \mathrm{L}$} \\
\hline & \multicolumn{4}{|c|}{ Tempo de contato (min) } \\
\hline Parâmetros & 5,0 & 10,0 & 15,0 & 20,0 \\
\hline $\mathrm{pH}$ & 7,5 & 7,6 & 7,6 & 7,6 \\
\hline Alcalinidade $\left(\mathrm{mg} / \mathrm{LcaCO}_{3}\right)$ & 99,8 & 95,81 & 59,88 & 91,82 \\
\hline Temperatura $\left({ }^{\circ} \mathrm{C}\right)$ & 23 & 23 & 23 & 23 \\
\hline Abs $(254 \mathrm{~nm})$ & 0,174 & 0,195 & 0,225 & 0,240 \\
\hline $\mathrm{COT}(\mathrm{mg} / \mathrm{L})$ & 30,25 & 27,09 & 29,91 & 30,07 \\
\hline Cloro residual livre $\left(\mathrm{mgCl}_{2} / \mathrm{L}\right)$ & 0,08 & 0,06 & 0,06 & 0,08 \\
\hline Cloro residual total $\left(\mathrm{mgCl}_{2} / \mathrm{L}\right)$ & 1,47 & 1,45 & 1,42 & 1,39 \\
\hline E. coli $(U F C / 100 \mathrm{~mL})$ & $5,0 \times 10^{5}$ & $7,0 \times 10^{4}$ & $5,0 \times 10^{4}$ & $1,3 \times 10^{4}$ \\
\hline Colifagos (UFP/100 mL) & $1,5 \times 10^{3}$ & $1,5 \times 10^{3}$ & $1,5 \times 10^{3}$ & $5,0 \times 10^{2}$ \\
\hline C. perfringens $((\mathrm{NMP} / 100 \mathrm{~mL})$ & $3,3 \times 10^{3}$ & $2,8 \times 10^{3}$ & $1,1 \times 10^{3}$ & $8 \times 10^{2}$ \\
\hline
\end{tabular}

TABELA A 06 - Características da água de estudo bruta (cor elevada) e das amostras após a desinfecção com cloro aplicado em concentração de $3,0 \mathrm{mg} / \mathrm{L}$.

\begin{tabular}{|c|c|c|c|c|}
\hline Parâmetros & \multicolumn{4}{|c|}{ Água de estudo } \\
\hline $\mathrm{pH}$ & \multicolumn{4}{|c|}{7,2} \\
\hline Alcalinidade $\left(\mathrm{mg} / \mathrm{L} \mathrm{CaCO}_{3}\right)$ & \multicolumn{4}{|c|}{123,7} \\
\hline Temperatura $\left({ }^{\circ} \mathrm{C}\right)$ & \multicolumn{4}{|c|}{23} \\
\hline Abs (254 nm) & \multicolumn{4}{|c|}{0,245} \\
\hline $\mathrm{COT}(\mathrm{mg} / \mathrm{L})$ & \multicolumn{4}{|c|}{31,71} \\
\hline Cor verdadeira $(\mathrm{uH})$ & \multicolumn{4}{|c|}{233} \\
\hline Turbidez (uT) & \multicolumn{4}{|c|}{0,57} \\
\hline E. coli $(U F C / 100 \mathrm{~mL})$ & \multicolumn{4}{|c|}{$1,0 \times 10^{6}$} \\
\hline Colifagos (UFP/100 mL) & \multicolumn{4}{|c|}{$1,5 \times 10^{4}$} \\
\hline C. perfringens $((\mathrm{NMP} / 100 \mathrm{~mL})$ & \multicolumn{4}{|c|}{$1 \times 10^{5}$} \\
\hline & \multicolumn{4}{|c|}{ Cloro aplicado: $3,0 \mathrm{mg} / \mathrm{L}$} \\
\hline & \multicolumn{4}{|c|}{ Tempo de contato (min) } \\
\hline Parâmetros & $\mathbf{5 , 0}$ & 10,0 & 15,0 & 20,0 \\
\hline $\mathrm{pH}$ & 7,5 & 7,7 & 7,6 & 7,7 \\
\hline Alcalinidade $\left(\mathrm{mg} / \mathrm{LcaCO}_{3}\right)$ & 171,6 & 171,6 & 131,7 & 119,7 \\
\hline Temperatura $\left({ }^{\circ} \mathrm{C}\right)$ & 23 & 23 & 23 & 23 \\
\hline Abs (254 nm) & 0,304 & 0,305 & 0,290 & 0,293 \\
\hline $\mathrm{COT}(\mathrm{mg} / \mathrm{L})$ & 33,53 & 35,05 & 25,73 & 29,88 \\
\hline Cloro residual livre $\left(\mathrm{mgCl}_{2} / \mathrm{L}\right)$ & 0,03 & 0,03 & 0,06 & 0,02 \\
\hline Cloro residual total $\left(\mathrm{mgCl}_{2} / \mathrm{L}\right)$ & 2,47 & 2,43 & 1,97 & 1,90 \\
\hline E. coli $(U F C / 100 \mathrm{~mL})$ & $3,0 \times 10^{4}$ & $1,0 \times 10^{4}$ & $5,0 \times 10^{3}$ & $3,0 \times 10^{4}$ \\
\hline Colifagos (UFP/100 mL) & $1,5 \times 10^{3}$ & $1,5 \times 10^{3}$ & $1,0 \times 10^{3}$ & 50 \\
\hline C. perfringens $((\mathrm{NMP} / 100 \mathrm{~mL})$ & $3 \times 10^{4}$ & $1,1 \times 10^{4}$ & $1,1 \times 10^{4}$ & $5 \times 10^{3}$ \\
\hline
\end{tabular}


TABELA A 07 - Características da água de estudo bruta (cor elevada) e das amostras após a desinfecção com cloro aplicado em concentração de 4,0 mg/L .

\begin{tabular}{|c|c|c|c|c|}
\hline Parâmetros & \multicolumn{4}{|c|}{ Água de estudo } \\
\hline $\mathrm{pH}$ & \multicolumn{4}{|c|}{7,2} \\
\hline Alcalinidade $\left(\mathrm{mg} / \mathrm{L} \mathrm{CaCO}_{3}\right)$ & \multicolumn{4}{|c|}{115,7} \\
\hline Temperatura $\left({ }^{\circ} \mathrm{C}\right)$ & \multicolumn{4}{|c|}{23} \\
\hline Abs (254 nm) & \multicolumn{4}{|c|}{0,248} \\
\hline $\mathrm{COT}(\mathrm{mg} / \mathrm{L})$ & \multicolumn{4}{|c|}{31,23} \\
\hline Cor verdadeira $(\mathrm{uH})$ & \multicolumn{4}{|c|}{180} \\
\hline Turbidez (uT) & \multicolumn{4}{|c|}{5} \\
\hline E. coli (UFC/ $100 \mathrm{~mL})$ & \multicolumn{4}{|c|}{$1,0 \times 10^{5}$} \\
\hline Colifagos (UFP/100 mL) & \multicolumn{4}{|c|}{$1,0 \times 10^{6}$} \\
\hline C. perfringens $((\mathrm{NMP} / 100 \mathrm{~mL})$ & \multicolumn{4}{|c|}{$5 \times 10^{5}$} \\
\hline & \multicolumn{4}{|c|}{ Cloro aplicado: $4,0 \mathrm{mg} / \mathrm{L}$} \\
\hline & \multicolumn{4}{|c|}{ Tempo de contato (min) } \\
\hline Parâmetros & $\mathbf{5 , 0}$ & 10,0 & 15,0 & 20,0 \\
\hline $\mathrm{pH}$ & 7,3 & 7,2 & 7,5 & 7,5 \\
\hline Alcalinidade $\left(\mathrm{mg} / \mathrm{LcaCO}_{3}\right)$ & 142 & 72,85 & 99,8 & 99,8 \\
\hline Temperatura $\left({ }^{\circ} \mathrm{C}\right)$ & 23 & 23 & 23 & 23 \\
\hline $\operatorname{Abs}(254 \mathrm{~nm})$ & 0,294 & 0,302 & 0,295 & 0,297 \\
\hline $\mathrm{COT}(\mathrm{mg} / \mathrm{L})$ & 32,43 & 35,02 & 26,73 & 30,02 \\
\hline Cloro residual livre $\left(\mathrm{mgCl}_{2} / \mathrm{L}\right)$ & 0,22 & 0,20 & 0,12 & 0,10 \\
\hline Cloro residual total $\left(\mathrm{mgCl}_{2} / \mathrm{L}\right)$ & 3,54 & 3,43 & 2,90 & 2,70 \\
\hline E. coli (UFC/ $100 \mathrm{~mL})$ & $4,0 \times 10^{3}$ & $2,0 \times 10^{3}$ & $11 \times 10^{2}$ & $9,0 \times 10^{2}$ \\
\hline Colifagos (UFP/100 mL) & $3,5 \times 10^{4}$ & $2,1 \times 10^{4}$ & $1,6 \times 10^{4}$ & $2,5 \times 10^{4}$ \\
\hline C. perfringens $((\mathrm{NMP} / 100 \mathrm{~mL})$ & $3,3 \times 10^{4}$ & $3,3 \times 10^{4}$ & $3,3 \times 10^{4}$ & $3,3 \times 10^{4}$ \\
\hline
\end{tabular}

TABELA A 08 - Características da água de estudo bruta (cor elevada) e das amostras após a desinfecção com cloro aplicado em concentração de 5,0 mg/L .

\begin{tabular}{|c|c|c|c|c|}
\hline Parâmetros & \multicolumn{4}{|c|}{ Água de estudo } \\
\hline $\mathrm{pH}$ & \multicolumn{4}{|c|}{7,5} \\
\hline Alcalinidade $\left(\mathrm{mg} / \mathrm{L} \mathrm{CaCO}_{3}\right)$ & \multicolumn{4}{|c|}{119,2} \\
\hline Temperatura $\left({ }^{\circ} \mathrm{C}\right)$ & \multicolumn{4}{|c|}{23} \\
\hline Abs $(254 \mathrm{~nm})$ & \multicolumn{4}{|c|}{0,257} \\
\hline $\mathrm{COT}(\mathrm{mg} / \mathrm{L})$ & \multicolumn{4}{|c|}{28,38} \\
\hline Cor verdadeira $(\mathrm{uH})$ & \multicolumn{4}{|c|}{173} \\
\hline Turbidez (uT) & \multicolumn{4}{|c|}{5} \\
\hline E. coli (UFC/ $100 \mathrm{~mL})$ & \multicolumn{4}{|c|}{$1,0 \times 10^{5}$} \\
\hline Colifagos (UFP/100 mL) & \multicolumn{4}{|c|}{$4,1 \times 10^{6}$} \\
\hline C. perfringens $((\mathrm{NMP} / 100 \mathrm{~mL})$ & \multicolumn{4}{|c|}{$5 \times 10^{5}$} \\
\hline & \multicolumn{4}{|c|}{ Cloro aplicado: $5,0 \mathrm{mg} / \mathrm{L}$} \\
\hline & \multicolumn{4}{|c|}{ Tempo de contato (min) } \\
\hline Parâmetros & $\mathbf{5 , 0}$ & $\mathbf{1 0 , 0}$ & 15,0 & 20,0 \\
\hline $\mathrm{pH}$ & 7,2 & 7,4 & 7,5 & 7,5 \\
\hline Alcalinidade $\left(\mathrm{mg} / \mathrm{LcaCO}_{3}\right)$ & 94,75 & 94,75 & 87,82 & 87,82 \\
\hline Temperatura $\left({ }^{\circ} \mathrm{C}\right)$ & 23 & 23 & 23 & 23 \\
\hline $\operatorname{Abs}(254 \mathrm{~nm})$ & 0,344 & 0,346 & 0,355 & 0,344 \\
\hline $\mathrm{COT}(\mathrm{mg} / \mathrm{L})$ & 30,20 & 30,04 & 28,48 & 28,74 \\
\hline Cloro residual livre $\left(\mathrm{mgCl}_{2} / \mathrm{L}\right)$ & 0,42 & 0,35 & 0,27 & 0,20 \\
\hline Cloro residual total $\left(\mathrm{mgCl}_{2} / \mathrm{L}\right)$ & 4,23 & 4,34 & 3,74 & 3,72 \\
\hline E. coli $(U F C / 100 \mathrm{~mL})$ & $3,0 \times 10^{3}$ & $2,0 \times 10^{3}$ & $2 \times 10^{2}$ & $1,0 \times 10^{2}$ \\
\hline Colifagos (UFP/100 mL) & $3,0 \times 10^{3}$ & $2,0 \times 10^{3}$ & $1,0 \times 10^{3}$ & $2,0 \times 10^{2}$ \\
\hline C. perfringens $((\mathrm{NMP} / 100 \mathrm{~mL})$ & $3,0 \times 10^{4}$ & $1,0 \times 10^{4}$ & $3,3 \times 10^{4}$ & $3,3 \times 10^{4}$ \\
\hline
\end{tabular}


TABELA A 09 - Características da água de estudo bruta sem meio de cultura e das amostras após desinfecção com cloro aplicado em concentração de 2,0 $\mathrm{mg} / \mathrm{L}$.

\begin{tabular}{|c|c|c|}
\hline Parâmetros & \multicolumn{2}{|c|}{ Água de estudo } \\
\hline $\mathrm{pH}$ & \multicolumn{2}{|c|}{7,2} \\
\hline Alcalinidade $\left(\mathrm{mg} / \mathrm{L} \mathrm{CaCO}_{3}\right)$ & \multicolumn{2}{|c|}{87,82} \\
\hline Temperatura $\left({ }^{\circ} \mathrm{C}\right)$ & \multicolumn{2}{|c|}{23} \\
\hline Abs $(254 \mathrm{~nm})$ & \multicolumn{2}{|c|}{0,009} \\
\hline COT $(\mathrm{mg} / \mathrm{L})$ & \multicolumn{2}{|c|}{3,248} \\
\hline Cor verdadeira $(\mathrm{uH})$ & \multicolumn{2}{|c|}{3} \\
\hline Turbidez (uT) & \multicolumn{2}{|c|}{0,1} \\
\hline E. coli $(U F C / 100 \mathrm{~mL})$ & \multicolumn{2}{|c|}{$9,0 \times 10^{4}$} \\
\hline Colifagos (UFP/100 mL) & \multicolumn{2}{|c|}{-} \\
\hline C. perfringens $((\mathrm{NMP} / 100 \mathrm{~mL})$ & \multicolumn{2}{|c|}{$8 \times 10^{5}$} \\
\hline & \multicolumn{2}{|c|}{ Tempo de contato: $20 \mathrm{~min}$} \\
\hline & \multicolumn{2}{|c|}{ Cloro aplicado } \\
\hline Parâmetros & 2,0 & 5,0 \\
\hline $\mathrm{pH}$ & 7,2 & 7,0 \\
\hline Alcalinidade $\left(\mathrm{mg} / \mathrm{LcaCO}_{3}\right)$ & 87,82 & 94,75 \\
\hline Temperatura $\left({ }^{\circ} \mathrm{C}\right)$ & 23 & 23 \\
\hline Abs (254 nm) & 0,006 & 0,008 \\
\hline $\mathrm{COT}(\mathrm{mg} / \mathrm{L})$ & 4,892 & 4,313 \\
\hline Cloro residual livre $\left(\mathrm{mgCl}_{2} / \mathrm{L}\right)$ & 1,49 & 4,07 \\
\hline E. coli $(U F C / 100 \mathrm{~mL})$ & 1 & 4 \\
\hline Colifagos (UFP/100 mL) & - & - \\
\hline C. perfringens $((\mathrm{NMP} / 100 \mathrm{~mL})$ & $1,1 \times 10^{-3}$ & 700 \\
\hline
\end{tabular}

TABELA A 10 - Características da água de estudo bruta (cor baixa) e das amostras após a desinfecção com ácido peracético aplicado em concentração 2,0 $\mathrm{mg} / \mathrm{L}$.

\begin{tabular}{|c|c|c|c|c|}
\hline Parâmetros & \multicolumn{4}{|c|}{ Água de estudo } \\
\hline $\mathrm{pH}$ & \multicolumn{4}{|c|}{7,5} \\
\hline Alcalinidade $\left(\mathrm{mg} / \mathrm{L} \mathrm{CaCO}_{3}\right)$ & \multicolumn{4}{|c|}{83,83} \\
\hline Temperatura $\left({ }^{\circ} \mathrm{C}\right)$ & \multicolumn{4}{|c|}{23} \\
\hline Abs $(254 \mathrm{~nm})$ & \multicolumn{4}{|c|}{0,072} \\
\hline $\mathrm{COT}(\mathrm{mg} / \mathrm{L})$ & \multicolumn{4}{|c|}{18,76} \\
\hline Cor verdadeira $(\mathrm{uC})$ & \multicolumn{4}{|c|}{28} \\
\hline Turbidez (uT) & \multicolumn{4}{|c|}{0,56} \\
\hline E. coli $(U F C / 100 \mathrm{~mL})$ & \multicolumn{4}{|c|}{$2 \times 10^{7}$} \\
\hline Colifagos (UFP/100 mL) & \multicolumn{4}{|c|}{$1 \times 10^{5}$} \\
\hline C. perfringens $((\mathrm{NMP} / 100 \mathrm{~mL})$ & \multicolumn{4}{|c|}{$3 \times 10^{7}$} \\
\hline & \multicolumn{4}{|c|}{ Ácido peracético aplicado: $2,0 \mathrm{mg} / \mathrm{L}$} \\
\hline & \multicolumn{4}{|c|}{ Tempo de contato (min) } \\
\hline Parâmetros & $\mathbf{5 , 0}$ & 10,0 & 15,0 & 20,0 \\
\hline $\mathrm{pH}$ & 7,0 & 7,3 & 7,4 & 6,9 \\
\hline Alcalinidade $\left(\mathrm{mg} / \mathrm{LcaCO}_{3}\right)$ & 79,84 & 75,85 & 91,82 & 83,83 \\
\hline Temperatura $\left({ }^{\circ} \mathrm{C}\right)$ & 23 & 23 & 23 & 23 \\
\hline Abs $(254 \mathrm{~nm})$ & 0,117 & 0,142 & 0,129 & 0,140 \\
\hline $\mathrm{COT}(\mathrm{mg} / \mathrm{L})$ & 21,02 & 19,91 & 20,99 & 20,25 \\
\hline Ácido peracético residual & 1,28 & 1,26 & 1,18 & 1,03 \\
\hline E. coli $(U F C / 100 \mathrm{~mL})$ & $1 \times 10^{4}$ & $2,5 \times 10^{3}$ & $3 \times 10^{2}$ & $2 \times 10^{2}$ \\
\hline Colifagos (UFP/100 mL) & $2,6 \times 10^{4}$ & $2 \times 10^{4}$ & $1 \times 10^{4}$ & $2 \times 10^{3}$ \\
\hline C. perfringens $((\mathrm{NMP} / 100 \mathrm{~mL})$ & $4 \times 10^{5}$ & $2 \times 10^{5}$ & $2 \times 10^{5}$ & $2 \times 10^{5}$ \\
\hline
\end{tabular}


TABELA A 11 - Características da água de estudo bruta (cor baixa) e das amostras após a desinfecção com ácido peracético aplicado em concentração 3,0 $\mathrm{mg} / \mathrm{L}$.

\begin{tabular}{|c|c|c|c|c|}
\hline Parâmetros & \multicolumn{4}{|c|}{ Água de estudo } \\
\hline $\mathrm{pH}$ & \multicolumn{4}{|c|}{7,6} \\
\hline Alcalinidade $\left(\mathrm{mg} / \mathrm{L} \mathrm{CaCO}_{3}\right)$ & \multicolumn{4}{|c|}{79,84} \\
\hline Temperatura $\left({ }^{\circ} \mathrm{C}\right)$ & \multicolumn{4}{|c|}{24} \\
\hline Abs $(254 \mathrm{~nm})$ & \multicolumn{4}{|c|}{0,052} \\
\hline $\mathrm{COT}(\mathrm{mg} / \mathrm{L})$ & \multicolumn{4}{|c|}{4,592} \\
\hline Cor verdadeira $(\mathrm{uC})$ & \multicolumn{4}{|c|}{25} \\
\hline Turbidez (uT) & \multicolumn{4}{|c|}{0,69} \\
\hline E. coli $(U F C / 100 \mathrm{~mL})$ & \multicolumn{4}{|c|}{$5 \times 10^{5}$} \\
\hline Colifagos (UFP/100 mL) & \multicolumn{4}{|c|}{$8 \times 10^{7}$} \\
\hline C. perfringens $((\mathrm{NMP} / 100 \mathrm{~mL})$ & \multicolumn{4}{|c|}{$1,1 \times 10^{6}$} \\
\hline & \multicolumn{4}{|c|}{ Ácido peracético aplicado: $3,0 \mathrm{mg} / \mathrm{L}$} \\
\hline & \multicolumn{4}{|c|}{ Tempo de contato (min) } \\
\hline Parâmetros & $\mathbf{5 , 0}$ & $\mathbf{1 0 , 0}$ & 15,0 & 20,0 \\
\hline $\mathrm{pH}$ & 7,1 & 7,3 & 7,2 & 7,2 \\
\hline \multicolumn{5}{|l|}{ Alcalinidade $\left(\mathrm{mg} / \mathrm{LcaCO}_{3}\right)$} \\
\hline Temperatura $\left({ }^{\circ} \mathrm{C}\right)$ & 24 & 24 & 24 & 24 \\
\hline $\operatorname{Abs}(254 \mathrm{~nm})$ & 0,141 & 0,248 & 0,147 & 0,158 \\
\hline $\mathrm{COT}(\mathrm{mg} / \mathrm{L})$ & 4,749 & 4,360 & 4,726 & 4,362 \\
\hline Ácido peracético residual & 2,28 & 1,96 & 1,87 & 1,74 \\
\hline E. coli $(U F C / 100 \mathrm{~mL})$ & $2 \times 10^{3}$ & $2 \times 10^{3}$ & $1 \times 10^{2}$ & $1 \times 10^{2}$ \\
\hline Colifagos (UFP/100 mL) & $8,9 \times 10^{6}$ & $6,6 \times 10^{6}$ & $4,8 \times 10^{6}$ & $3,7 \times 10^{6}$ \\
\hline Clostridium perfringens $(\mathrm{NMP} / 100 \mathrm{~mL})$ & $1,1 \times 10^{6}$ & $3,4 \times 10^{5}$ & $1,7 \times 10^{5}$ & $1,7 \times 10^{5}$ \\
\hline
\end{tabular}

TABELA A 12 - Características da água de estudo bruta (cor baixa) e das amostras após a desinfecção com ácido peracético aplicado em concentração 4,0 $\mathrm{mg} / \mathrm{L}$.

\begin{tabular}{|c|c|c|c|c|}
\hline Parâmetros & \multicolumn{4}{|c|}{ Áqua de estudo } \\
\hline$\overline{\mathrm{pH}}$ & \multicolumn{4}{|c|}{7,0} \\
\hline Alcalinidade $\left(\mathrm{mg} / \mathrm{L} \mathrm{CaCO}_{3}\right)$ & \multicolumn{4}{|c|}{75,85} \\
\hline Temperatura $\left({ }^{\circ} \mathrm{C}\right)$ & \multicolumn{4}{|c|}{23} \\
\hline Abs $(254 \mathrm{~nm})$ & \multicolumn{4}{|c|}{0,054} \\
\hline $\mathrm{COT}(\mathrm{mg} / \mathrm{L})$ & \multicolumn{4}{|c|}{17,28} \\
\hline Cor verdadeira (uC) & \multicolumn{4}{|c|}{32} \\
\hline Turbidez (uT) & \multicolumn{4}{|c|}{0,72} \\
\hline E. coli $(U F C / 100 \mathrm{~mL})$ & \multicolumn{4}{|c|}{$2 \times 10^{6}$} \\
\hline Colifagos (UFP/100 mL) & \multicolumn{4}{|c|}{$1 \times 10^{7}$} \\
\hline C. perfringens $((\mathrm{NMP} / 100 \mathrm{~mL})$ & \multicolumn{4}{|c|}{$3 \times 10^{6}$} \\
\hline & \multicolumn{4}{|c|}{ Ácido peracético aplicado: $4,0 \mathrm{mg} / \mathrm{L}$} \\
\hline & \multicolumn{4}{|c|}{ Tempo de contato (min) } \\
\hline Parâmetros & $\mathbf{5 , 0}$ & 10,0 & 15,0 & 20,0 \\
\hline$\overline{\mathrm{pH}}$ & 7,7 & 7,2 & 7,3 & 7,5 \\
\hline Alcalinidade $\left(\mathrm{mg} / \mathrm{LcaCO}_{3}\right)$ & 87,83 & 83,83 & 91,82 & 87,83 \\
\hline Temperatura $\left({ }^{\circ} \mathrm{C}\right)$ & 23 & 23 & 23 & 23 \\
\hline Abs (254 nm) & 0,243 & 0,289 & 0,270 & 0,284 \\
\hline $\mathrm{COT}(\mathrm{mg} / \mathrm{L})$ & 19,92 & 20,43 & 20,30 & 20,12 \\
\hline Ácido peracético residual & 2,65 & 2,47 & 2,43 & 2,42 \\
\hline E. coli $(U F C / 100 \mathrm{~mL})$ & $7 \times 10^{2}$ & $8 \times 10^{2}$ & 83 & 64 \\
\hline Colifagos (UFP/100 mL) & $2,5 \times 10^{5}$ & $2,0 \times 10^{5}$ & $1,4 \times 10^{5}$ & $1,0 \times 10^{5}$ \\
\hline C. perfringens $((\mathrm{NMP} / 100 \mathrm{~mL})$ & $1,1 \times 10^{6}$ & $2,2 \times 10^{5}$ & $3 \times 10^{5}$ & $5 \times 10^{5}$ \\
\hline
\end{tabular}


TABELA A 13 - Características da água de estudo bruta (cor baixa) e das amostras após a desinfecção com ácido peracético aplicado em concentração 5,0 $\mathrm{mg} / \mathrm{L}$.

\begin{tabular}{|c|c|c|c|c|}
\hline Parâmetros & \multicolumn{4}{|c|}{ Água de estudo } \\
\hline $\mathrm{pH}$ & \multicolumn{4}{|c|}{7,2} \\
\hline Alcalinidade $\left(\mathrm{mg} / \mathrm{L} \mathrm{CaCO}_{3}\right)$ & \multicolumn{4}{|c|}{87,82} \\
\hline Temperatura $\left({ }^{\circ} \mathrm{C}\right)$ & \multicolumn{4}{|c|}{25} \\
\hline Abs (254 nm) & \multicolumn{4}{|c|}{0,016} \\
\hline $\mathrm{COT}(\mathrm{mg} / \mathrm{L})$ & \multicolumn{4}{|c|}{5,254} \\
\hline Cor verdadeira $(\mathrm{uC})$ & \multicolumn{4}{|c|}{41} \\
\hline Turbidez (uT) & \multicolumn{4}{|c|}{0,32} \\
\hline E. coli $(U F C / 100 \mathrm{~mL})$ & \multicolumn{4}{|c|}{$1 \times 10^{6}$} \\
\hline Colifagos (UFP/100 mL) & \multicolumn{4}{|c|}{$1 \times 10^{6}$} \\
\hline C. perfringens $((\mathrm{NMP} / 100 \mathrm{~mL})$ & \multicolumn{4}{|c|}{$1 \times 10^{7}$} \\
\hline & \multicolumn{4}{|c|}{ Ácido peracético aplicado: $5,0 \mathrm{mg} / \mathrm{L}$} \\
\hline & \multicolumn{4}{|c|}{ Tempo de contato $(\mathrm{min})$} \\
\hline Parâmetros & $\mathbf{5 , 0}$ & 10,0 & 15,0 & 20,0 \\
\hline $\mathrm{pH}$ & 7,5 & 7,3 & 7,7 & 7,5 \\
\hline Alcalinidade $\left(\mathrm{mg} / \mathrm{LcaCO}_{3}\right)$ & 87,82 & 83,83 & 79,84 & 83,83 \\
\hline Temperatura $\left({ }^{\circ} \mathrm{C}\right)$ & 25 & 25 & 25 & 25 \\
\hline Abs $(254 \mathrm{~nm})$ & 0,359 & 0,300 & 0,375 & 0,093 \\
\hline $\mathrm{COT}(\mathrm{mg} / \mathrm{L})$ & 21,81 & 29,39 & 26,04 & 22,49 \\
\hline Ácido peracético residual & 3,27 & 3,14 & 2,80 & 2,73 \\
\hline E. coli $(U F C / 100 \mathrm{~mL})$ & $3 \times 10^{2}$ & 90 & 70 & 10 \\
\hline Colifagos (UFP/100 mL) & $3 \times 10^{5}$ & $1 \times 10^{5}$ & $5 \times 10^{4}$ & $3 \times 10^{4}$ \\
\hline C. perfringens $((\mathrm{NMP} / 100 \mathrm{~mL})$ & $3 \times 10^{6}$ & $5 \times 10^{5}$ & $2,7 \times 10^{5}$ & $3,3 \times 10^{5}$ \\
\hline
\end{tabular}

TABELA A 14 - Características da água de estudo bruta (cor elevada) e das amostras após a desinfecção com ácido peracético aplicado em concentração 2,0 $\mathrm{mg} / \mathrm{L}$.

\begin{tabular}{|c|c|c|c|c|}
\hline Parâmetros & \multicolumn{4}{|c|}{ Água de estudo } \\
\hline $\mathrm{pH}$ & \multicolumn{4}{|c|}{6,0} \\
\hline Alcalinidade $\left(\mathrm{mg} / \mathrm{L} \mathrm{CaCO}_{3}\right)$ & \multicolumn{4}{|c|}{91,82} \\
\hline Temperatura $\left({ }^{\circ} \mathrm{C}\right)$ & \multicolumn{4}{|c|}{23} \\
\hline Abs $(254 \mathrm{~nm})$ & \multicolumn{4}{|c|}{0,352} \\
\hline $\mathrm{COT}(\mathrm{mg} / \mathrm{L})$ & \multicolumn{4}{|c|}{30,13} \\
\hline Cor verdadeira $(\mathrm{uC})$ & \multicolumn{4}{|c|}{255} \\
\hline Turbidez (uT) & \multicolumn{4}{|c|}{0,56} \\
\hline E. coli $(U F C / 100 \mathrm{~mL})$ & \multicolumn{4}{|c|}{$2 \times 10^{6}$} \\
\hline Colifagos (UFP/100 mL) & \multicolumn{4}{|c|}{$2 \times 10^{6}$} \\
\hline C. perfringens $((\mathrm{NMP} / 100 \mathrm{~mL})$ & \multicolumn{4}{|c|}{$1,1 \times 10^{5}$} \\
\hline & \multicolumn{4}{|c|}{ Ácido peracético aplicado: $2,0 \mathrm{mg} / \mathrm{L}$} \\
\hline & \multicolumn{4}{|c|}{ Tempo de contato $(\min )$} \\
\hline Parâmetros & 5,0 & 10,0 & 15,0 & 20,0 \\
\hline $\mathrm{pH}$ & 6,5 & 6,7 & 6,9 & 6,6 \\
\hline Alcalinidade $\left(\mathrm{mg} / \mathrm{LcaCO}_{3}\right)$ & 99,8 & 103,79 & 111,77 & 107,78 \\
\hline Temperatura $\left({ }^{\circ} \mathrm{C}\right)$ & 23 & 23 & 23 & 23 \\
\hline $\operatorname{Abs}(254 \mathrm{~nm})$ & 0,406 & 0,405 & 0,414 & 0,400 \\
\hline $\mathrm{COT}(\mathrm{mg} / \mathrm{L})$ & 32,08 & 32,97 & 32,28 & 32,78 \\
\hline Ácido peracético residual & 1,11 & 0,70 & 0,66 & 0,47 \\
\hline E. coli $(U F C / 100 \mathrm{~mL})$ & $7 \times 10^{4}$ & $4,5 \times 10^{2}$ & 10 & 10 \\
\hline Colifagos (UFP/100 mL) & $4,6 \times 10^{5}$ & $4,5 \times 10^{4}$ & $2,5 \times 10^{4}$ & $5 \times 10^{3}$ \\
\hline C. perfringens $((\mathrm{NMP} / 100 \mathrm{~mL})$ & $5 \times 10^{4}$ & $2 \times 10^{3}$ & $9 \times 10^{3}$ & $4 \times 10^{3}$ \\
\hline
\end{tabular}


T ABELA A 15 - Características da água de estudo bruta (cor elevada) e das amostras após a desinfecção com ácido peracético aplicado em concentração 3,0 $\mathrm{mg} / \mathrm{L}$.

\begin{tabular}{|c|c|c|c|c|}
\hline Parâmetros & \multicolumn{4}{|c|}{ Água de estudo } \\
\hline $\mathrm{pH}$ & \multicolumn{4}{|c|}{6,4} \\
\hline Alcalinidade $\left(\mathrm{mg} / \mathrm{L} \mathrm{CaCO}_{3}\right)$ & \multicolumn{4}{|c|}{95,81} \\
\hline Temperatura $\left({ }^{\circ} \mathrm{C}\right)$ & \multicolumn{4}{|c|}{23} \\
\hline Abs $(254 \mathrm{~nm})$ & \multicolumn{4}{|c|}{0,284} \\
\hline $\mathrm{COT}(\mathrm{mg} / \mathrm{L})$ & \multicolumn{4}{|c|}{28,68} \\
\hline Cor verdadeira $(\mathrm{uC})$ & \multicolumn{4}{|c|}{208} \\
\hline Turbidez (uT) & \multicolumn{4}{|c|}{1,93} \\
\hline E. coli $(U F C / 100 \mathrm{~mL})$ & \multicolumn{4}{|c|}{$1,6 \times 10^{6}$} \\
\hline Colifagos (UFP/100 mL) & \multicolumn{4}{|c|}{$5 \times 10^{6}$} \\
\hline C. perfringens $((\mathrm{NMP} / 100 \mathrm{~mL})$ & \multicolumn{4}{|c|}{$8 \times 10^{4}$} \\
\hline & \multicolumn{4}{|c|}{ Ácido peracético aplicado: $3,0 \mathrm{mg} / \mathrm{L}$} \\
\hline & \multicolumn{4}{|c|}{ Tempo de contato (min) } \\
\hline Parâmetros & $\mathbf{5 , 0}$ & $\mathbf{1 0 , 0}$ & 15,0 & 20,0 \\
\hline $\mathrm{pH}$ & 6,9 & 6,8 & 7,3 & 7,2 \\
\hline Alcalinidade $\left(\mathrm{mg} / \mathrm{LcaCO}_{3}\right)$ & 83,83 & 95,81 & 91,82 & 99,8 \\
\hline Temperatura $\left({ }^{\circ} \mathrm{C}\right)$ & 23 & 23 & 23 & 23 \\
\hline $\operatorname{Abs}(254 \mathrm{~nm})$ & 0,381 & 0,382 & 0,429 & 0,378 \\
\hline $\mathrm{COT}(\mathrm{mg} / \mathrm{L})$ & 32,05 & 31,76 & 30,47 & 31,15 \\
\hline Ácido peracético residual & 1,55 & 1,18 & 1,05 & 1,06 \\
\hline E. coli $(U F C / 100 \mathrm{~mL})$ & $6 \times 10^{2}$ & $3 \times 10^{2}$ & $1 \times 10^{2}$ & 10 \\
\hline Colifagos (UFP/100 mL) & $3,45 \times 10^{5}$ & $4,5 \times 10^{4}$ & $6,5 \times 10^{3}$ & $2 \times 10^{3}$ \\
\hline C. perfringens $((\mathrm{NMP} / 100 \mathrm{~mL})$ & $2,3 \times 10^{4}$ & $2,3 \times 10^{4}$ & $4 \times 10^{3}$ & $2 \times 10^{3}$ \\
\hline
\end{tabular}

T ABELA A 16 - Características da água de estudo bruta (cor elevada) e das amostras após a desinfecção com ácido peracético aplicado em concentração 4,0 $\mathrm{mg} / \mathrm{L}$.

\begin{tabular}{|c|c|c|c|c|}
\hline Parâmetros & \multicolumn{4}{|c|}{ Áqua de estudo } \\
\hline$\overline{\mathrm{pH}}$ & \multicolumn{4}{|c|}{6,9} \\
\hline Alcalinidade $\left(\mathrm{mg} / \mathrm{L} \mathrm{CaCO}_{3}\right)$ & \multicolumn{4}{|c|}{87,82} \\
\hline Temperatura $\left({ }^{\circ} \mathrm{C}\right)$ & \multicolumn{4}{|c|}{23} \\
\hline Abs $(254 \mathrm{~nm})$ & \multicolumn{4}{|c|}{0,208} \\
\hline $\mathrm{COT}(\mathrm{mg} / \mathrm{L})$ & \multicolumn{4}{|c|}{15,53} \\
\hline Cor verdadeira (uC) & \multicolumn{4}{|c|}{186} \\
\hline Turbidez (uT) & \multicolumn{4}{|c|}{0,41} \\
\hline E. coli $(U F C / 100 \mathrm{~mL})$ & \multicolumn{4}{|c|}{$1,0 \times 10^{6}$} \\
\hline Colifagos (UFP/100 mL) & \multicolumn{4}{|c|}{$1 \times 10^{5}$} \\
\hline C. perfringens $((\mathrm{NMP} / 100 \mathrm{~mL})$ & \multicolumn{4}{|c|}{$5 \times 10^{4}$} \\
\hline & \multicolumn{4}{|c|}{ Ácido peracético aplicado: $4,0 \mathrm{mg} / \mathrm{L}$} \\
\hline & \multicolumn{4}{|c|}{ Tempo de contato (min) } \\
\hline Parâmetros & $\mathbf{5 , 0}$ & 10,0 & 15,0 & 20,0 \\
\hline$\overline{\mathrm{pH}}$ & 6,5 & 6,5 & 6,6 & 6,6 \\
\hline Alcalinidade $\left(\mathrm{mg} / \mathrm{LcaCO}_{3}\right)$ & 71,86 & 75,85 & 79,84 & 67,86 \\
\hline Temperatura $\left({ }^{\circ} \mathrm{C}\right)$ & 23 & 23 & 23 & 23 \\
\hline Abs (254 nm) & 0,305 & 0,291 & 0,293 & 0,298 \\
\hline $\mathrm{COT}(\mathrm{mg} / \mathrm{L})$ & 28,63 & 28,67 & 27,19 & 28,76 \\
\hline Ácido peracético residual & 2,10 & 2,27 & 2,36 & 2,20 \\
\hline E. coli $(U F C / 100 \mathrm{~mL})$ & 30 & 10 & 2 & 1 \\
\hline Colifagos (UFP/100 mL) & $5 \times 10^{3}$ & $3 \times 10^{3}$ & $3 \times 10^{3}$ & $5 \times 10^{2}$ \\
\hline C. perfringens $((\mathrm{NMP} / 100 \mathrm{~mL})$ & $8 \times 10^{3}$ & $4 \times 10^{3}$ & $4 \times 10^{3}$ & $2 \times 10^{3}$ \\
\hline
\end{tabular}


T ABELA A 17 - Características da água de estudo bruta (cor elevada) e das amostras após a desinfecção com ácido peracético aplicado em concentração 5,0 $\mathrm{mg} / \mathrm{L}$.

\begin{tabular}{|c|c|c|c|c|}
\hline Parâmetros & \multicolumn{4}{|c|}{ Água de estudo } \\
\hline $\mathrm{pH}$ & \multicolumn{4}{|c|}{7,3} \\
\hline Alcalinidade $\left(\mathrm{mg} / \mathrm{L} \mathrm{CaCO}_{3}\right)$ & \multicolumn{4}{|c|}{99,8} \\
\hline Temperatura $\left({ }^{\circ} \mathrm{C}\right)$ & \multicolumn{4}{|c|}{23} \\
\hline Abs (254 nm) & \multicolumn{4}{|c|}{0,190} \\
\hline $\mathrm{COT}(\mathrm{mg} / \mathrm{L})$ & \multicolumn{4}{|c|}{14,53} \\
\hline Cor verdadeira $(\mathrm{uC})$ & \multicolumn{4}{|c|}{164} \\
\hline Turbidez (uT) & \multicolumn{4}{|c|}{0,30} \\
\hline E. coli $(U F C / 100 \mathrm{~mL})$ & \multicolumn{4}{|c|}{$1,0 \times 10^{6}$} \\
\hline Colifagos (UFP/100 mL) & \multicolumn{4}{|c|}{$1 \times 10^{5}$} \\
\hline C. perfringens $((\mathrm{NMP} / 100 \mathrm{~mL})$ & \multicolumn{4}{|c|}{$1,3 \times 10^{4}$} \\
\hline & \multicolumn{4}{|c|}{ Ácido peracético aplicado: $5,0 \mathrm{mg} / \mathrm{L}$} \\
\hline & \multicolumn{4}{|c|}{ Tempo de contato $(\mathrm{min})$} \\
\hline Parâmetros & $\mathbf{5 , 0}$ & 10,0 & 15,0 & 20,0 \\
\hline$\overline{\mathrm{pH}}$ & 7,1 & 7,5 & 7,2 & 7,2 \\
\hline Alcalinidade $\left(\mathrm{mg} / \mathrm{LcaCO}_{3}\right)$ & 83,83 & 91,82 & 99,8 & 91,82 \\
\hline Temperatura $\left({ }^{\circ} \mathrm{C}\right)$ & 23 & 23 & 23 & 23 \\
\hline $\operatorname{Abs}(254 \mathrm{~nm})$ & 0,260 & 0,225 & 0,266 & 0,258 \\
\hline $\mathrm{COT}(\mathrm{mg} / \mathrm{L})$ & 24,03 & 15,89 & 25,24 & 25,28 \\
\hline Ácido peracético residual & 2,80 & 2,74 & 2,52 & 2,37 \\
\hline E. coli $(U F C / 100 \mathrm{~mL})$ & 5 & 4 & $<1$ & $<1$ \\
\hline Colifagos (UFP/100 mL) & 250 & 55 & 20 & $<1$ \\
\hline C. perfringens $((\mathrm{NMP} / 100 \mathrm{~mL})$ & 80 & $<1$ & $<1$ & $<1$ \\
\hline
\end{tabular}

TABELA A 18 - Características da água de estudo bruta (cor baixa) e das amostras após a desinfecção com ozônio aplicado em concentração 2,0 mg/L.

\begin{tabular}{|c|c|c|c|c|}
\hline Parâmetros & \multicolumn{4}{|c|}{ Água de estudo } \\
\hline$\overline{\mathrm{pH}}$ & \multicolumn{4}{|c|}{7,2} \\
\hline Alcalinidade $\left(\mathrm{mg} / \mathrm{L} \mathrm{CaCO}_{3}\right)$ & \multicolumn{4}{|c|}{83,83} \\
\hline Temperatura $\left({ }^{\circ} \mathrm{C}\right)$ & \multicolumn{4}{|c|}{23} \\
\hline Abs (254 nm) & \multicolumn{4}{|c|}{0,043} \\
\hline $\mathrm{COT}(\mathrm{mg} / \mathrm{L})$ & \multicolumn{4}{|c|}{10,92} \\
\hline Cor verdadeira $(\mathrm{uC})$ & \multicolumn{4}{|c|}{42} \\
\hline Turbidez (uT) & \multicolumn{4}{|c|}{0,28} \\
\hline E. coli (UFC/ $100 \mathrm{~mL})$ & \multicolumn{4}{|c|}{$1,0 \times 10^{6}$} \\
\hline Colifagos (UFP/100 mL) & \multicolumn{4}{|c|}{$2,0 \times 10^{4}$} \\
\hline C. perfringens $((\mathrm{NMP} / 100 \mathrm{~mL})$ & \multicolumn{4}{|c|}{$5,0 \times 10^{5}$} \\
\hline & \multicolumn{4}{|c|}{ Ozônio aplicado: $2,0 \mathrm{mg} / \mathrm{L}$} \\
\hline & \multicolumn{4}{|c|}{ Tempo de contato (min) } \\
\hline Parâmetros & 5,0 & 10,0 & 15,0 & 20,0 \\
\hline $\mathrm{pH}$ & 7,6 & 7,7 & 7,6 & 7,4 \\
\hline Alcalinidade $\left(\mathrm{mg} / \mathrm{LcaCO}_{3}\right)$ & 91,82 & 83,83 & 87,82 & 91,82 \\
\hline Temperatura $\left({ }^{\circ} \mathrm{C}\right)$ & 23 & 23 & 23 & 23 \\
\hline $\operatorname{Abs}(254 \mathrm{~nm})$ & 0,177 & 0,121 & 0,093 & 0,074 \\
\hline $\mathrm{COT}(\mathrm{mg} / \mathrm{L})$ & 39,28 & 36,86 & 39,67 & 28,63 \\
\hline Ozônio residual & 0,91 & 1,02 & 0,99 & 0,96 \\
\hline E. coli $(U F C / 100 \mathrm{~mL})$ & $3 \times 10^{4}$ & $2,5 \times 10^{4}$ & $1,1 \times 10^{4}$ & $8 \times 10^{3}$ \\
\hline Colifagos (UFP/100 mL) & $4,5 \times 10^{3}$ & $4,5 \times 10^{3}$ & $6,5 \times 10^{3}$ & $2,0 \times 10^{3}$ \\
\hline C. perfringens $((\mathrm{NMP} / 100 \mathrm{~mL})$ & $3,4 \times 10^{5}$ & $2,0 \times 10^{4}$ & $2,0 \times 10^{4}$ & $2,0 \times 10^{4}$ \\
\hline
\end{tabular}


T ABELA A 19 - Características da água de estudo bruta (cor baixa) e das amostras após a desinfecção com ozônio aplicado em concentração 3,0mg/L.

\begin{tabular}{|c|c|c|c|c|}
\hline Parâmetros & \multicolumn{4}{|c|}{ Água de estudo } \\
\hline $\mathrm{pH}$ & \multicolumn{4}{|c|}{7,3} \\
\hline Alcalinidade $\left(\mathrm{mg} / \mathrm{L} \mathrm{CaCO}_{3}\right)$ & \multicolumn{4}{|c|}{95,81} \\
\hline Temperatura $\left({ }^{\circ} \mathrm{C}\right)$ & \multicolumn{4}{|c|}{23} \\
\hline Abs $(254 \mathrm{~nm})$ & \multicolumn{4}{|c|}{0,284} \\
\hline $\operatorname{COT}(\mathrm{mg} / \mathrm{L})$ & \multicolumn{4}{|c|}{9,753} \\
\hline Cor verdadeira $(\mathrm{uC})$ & \multicolumn{4}{|c|}{25} \\
\hline Turbidez (uT) & \multicolumn{4}{|c|}{1,86} \\
\hline E. coli (UFC/100 mL) & \multicolumn{4}{|c|}{$1,0 \times 10^{5}$} \\
\hline Colifagos (UFP/100 mL) & \multicolumn{4}{|c|}{$9,5 \times 10^{5}$} \\
\hline C. perfringens $((\mathrm{NMP} / 100 \mathrm{~mL})$ & \multicolumn{4}{|c|}{$3,3 \times 10^{4}$} \\
\hline & \multicolumn{4}{|c|}{ Ozônio aplicado: 3,0 mg/L } \\
\hline & \multicolumn{4}{|c|}{ Tempo de contato (min) } \\
\hline Parâmetros & 5,0 & 10,0 & 15,0 & 20,0 \\
\hline $\mathrm{pH}$ & 7,1 & 7,5 & 7,0 & 7,6 \\
\hline Alcalinidade $\left(\mathrm{mg} / \mathrm{LcaCO}_{3}\right)$ & 99,8 & 99,8 & 87,82 & 95,81 \\
\hline Temperatura $\left({ }^{\circ} \mathrm{C}\right)$ & 23 & 23 & 23 & 23 \\
\hline Abs (254 nm) & 0,043 & 0,038 & 0,030 & 0,034 \\
\hline $\mathrm{COT}(\mathrm{mg} / \mathrm{L})$ & 25,05 & 24,29 & 24,58 & 18,97 \\
\hline Ozônio residual & 1,06 & 0,96 & 0,77 & 0,71 \\
\hline E. coli $(U F C / 100 \mathrm{~mL})$ & $6 \times 10^{2}$ & $3 \times 10^{2}$ & $1 \times 10^{2}$ & 10 \\
\hline Colifagos (UFP/100 mL) & $3,45 \times 10^{5}$ & $4,5 \times 10^{4}$ & $6,5 \times 10^{3}$ & $2 \times 10^{3}$ \\
\hline C. perfringens $((\mathrm{NMP} / 100 \mathrm{~mL})$ & $2,3 \times 10^{4}$ & $2,3 \times 10^{4}$ & $4 \times 10^{3}$ & $2 \times 10^{3}$ \\
\hline
\end{tabular}

T ABELA A 20 - Características da água de estudo bruta (cor baixa) e das amostras após a desinfecção com ozônio aplicado em concentração 4,0mg/L.

\begin{tabular}{|c|c|c|c|c|}
\hline Parâmetros & \multicolumn{4}{|c|}{ Água de estudo } \\
\hline$\overline{\mathrm{pH}}$ & \multicolumn{4}{|c|}{7,3} \\
\hline Alcalinidade $\left(\mathrm{mg} / \mathrm{L} \mathrm{CaCO}_{3}\right)$ & \multicolumn{4}{|c|}{87,82} \\
\hline Temperatura $\left({ }^{\circ} \mathrm{C}\right)$ & \multicolumn{4}{|c|}{23} \\
\hline Abs (254 nm) & \multicolumn{4}{|c|}{0,087} \\
\hline $\mathrm{COT}(\mathrm{mg} / \mathrm{L})$ & \multicolumn{4}{|c|}{55,71} \\
\hline Cor verdadeira (uC) & \multicolumn{4}{|c|}{20} \\
\hline Turbidez (uT) & \multicolumn{4}{|c|}{1,72} \\
\hline E. coli $(U F C / 100 \mathrm{~mL})$ & \multicolumn{4}{|c|}{$1,0 \times 10^{6}$} \\
\hline Colifagos (UFP/100 mL) & \multicolumn{4}{|c|}{$1,25 \times 10^{6}$} \\
\hline C. perfringens $((\mathrm{NMP} / 100 \mathrm{~mL})$ & \multicolumn{4}{|c|}{$1,4 \times 10^{5}$} \\
\hline & \multicolumn{4}{|c|}{ Ozônio aplicado: $4,0 \mathrm{mg} / \mathrm{L}$} \\
\hline & \multicolumn{4}{|c|}{ Tempo de contato (min) } \\
\hline Parâmetros & 5,0 & 10,0 & 15,0 & 20,0 \\
\hline$\overline{\mathrm{pH}}$ & 7,4 & 7,5 & 7,2 & 7,8 \\
\hline Alcalinidade $\left(\mathrm{mg} / \mathrm{LcaCO}_{3}\right)$ & 87,82 & 83,82 & 95,81 & 95,81 \\
\hline Temperatura $\left({ }^{\circ} \mathrm{C}\right)$ & 23 & 23 & 23 & 23 \\
\hline Abs (254 nm) & 0,086 & 0,084 & 0,084 & 0,086 \\
\hline $\mathrm{COT}(\mathrm{mg} / \mathrm{L})$ & 56,04 & 57,03 & 56,46 & $\overline{56,46}$ \\
\hline Ozônio residual & 1,03 & 1,02 & 0,93 & 0,92 \\
\hline E. coli $(U F C / 100 \mathrm{~mL})$ & 2000 & 1400 & 800 & 450 \\
\hline Colifagos (UFP/100 mL) & 150 & 150 & 10 & 5 \\
\hline C. perfringens $((\mathrm{NMP} / 100 \mathrm{~mL})$ & $5 \times 10^{4}$ & $8 \times 10^{3}$ & 200 & 200 \\
\hline
\end{tabular}


T ABELA A 21 - Características da água de estudo bruta (cor baixa) e das amostras após a desinfecção com ozônio aplicado em concentração 5,0 mg/L.

\begin{tabular}{|c|c|c|c|c|}
\hline Parâmetros & \multicolumn{4}{|c|}{ Água de estudo } \\
\hline $\mathrm{pH}$ & \multicolumn{4}{|c|}{7,2} \\
\hline Alcalinidade $\left(\mathrm{mg} / \mathrm{L} \mathrm{CaCO}_{3}\right)$ & \multicolumn{4}{|c|}{95,81} \\
\hline Temperatura $\left({ }^{\circ} \mathrm{C}\right)$ & \multicolumn{4}{|c|}{23} \\
\hline Abs $(254 \mathrm{~nm})$ & \multicolumn{4}{|c|}{0,080} \\
\hline $\mathrm{COT}(\mathrm{mg} / \mathrm{L})$ & \multicolumn{4}{|c|}{65,93} \\
\hline Cor verdadeira $(\mathrm{uC})$ & \multicolumn{4}{|c|}{32} \\
\hline Turbidez (uT) & \multicolumn{4}{|c|}{1,23} \\
\hline E. coli $(U F C / 100 \mathrm{~mL})$ & \multicolumn{4}{|c|}{$5,0 \times 10^{5}$} \\
\hline Colifagos (UFP/100 mL) & \multicolumn{4}{|c|}{$1,0 \times 10^{5}$} \\
\hline C. perfringens $((\mathrm{NMP} / 100 \mathrm{~mL})$ & \multicolumn{4}{|c|}{$9 \times 10^{6}$} \\
\hline & \multicolumn{4}{|c|}{ Ozônio aplicado: $5,0 \mathrm{mg} / \mathrm{L}$} \\
\hline & \multicolumn{4}{|c|}{ Tempo de contato (min) } \\
\hline Parâmetros & $\mathbf{5 , 0}$ & 10,0 & 15,0 & 20,0 \\
\hline $\mathrm{pH}$ & 7,0 & 6,8 & 7,6 & 7,6 \\
\hline Alcalinidade $\left(\mathrm{mg} / \mathrm{LcaCO}_{3}\right)$ & 87,82 & 87,82 & 83,83 & 83,83 \\
\hline Temperatura $\left({ }^{\circ} \mathrm{C}\right)$ & 23 & 23 & 23 & 23 \\
\hline Abs $(254 \mathrm{~nm})$ & 0,099 & 0,093 & 0,096 & 0,094 \\
\hline $\mathrm{COT}(\mathrm{mg} / \mathrm{L})$ & 66,54 & 66,42 & 66,16 & 65,12 \\
\hline Ozônio residual & 1,01 & 0,95 & 0,92 & 0,89 \\
\hline E. coli (UFC/ $100 \mathrm{~mL})$ & 300 & 80 & 110 & 200 \\
\hline Colifagos (UFP/100 mL) & 600 & 250 & 100 & 50 \\
\hline C. perfringens $((\mathrm{NMP} / 100 \mathrm{~mL})$ & $1,6 \times 10^{5}$ & $1,6 \times 10^{5}$ & $1,6 \times 10^{5}$ & $1,6 \times 10^{5}$ \\
\hline
\end{tabular}

TABELA A 22 - Características da água de estudo bruta (cor elevada) e das amostras após a desinfecção com ozônio aplicado em concentração 2,0 mg/L.

\begin{tabular}{|c|c|c|c|c|}
\hline Parâmetros & \multicolumn{4}{|c|}{ Água de estudo } \\
\hline $\mathrm{pH}$ & \multicolumn{4}{|c|}{7,2} \\
\hline Alcalinidade $\left(\mathrm{mg} / \mathrm{L} \mathrm{CaCO}_{3}\right)$ & \multicolumn{4}{|c|}{151,70} \\
\hline Temperatura $\left({ }^{\circ} \mathrm{C}\right)$ & \multicolumn{4}{|c|}{22} \\
\hline Abs $(254 \mathrm{~nm})$ & \multicolumn{4}{|c|}{0,073} \\
\hline $\mathrm{COT}(\mathrm{mg} / \mathrm{L})$ & \multicolumn{4}{|c|}{33,89} \\
\hline Cor verdadeira $(\mathrm{uH})$ & \multicolumn{4}{|c|}{209} \\
\hline Turbidez (uT) & \multicolumn{4}{|c|}{0,14} \\
\hline E. coli $(U F C / 100 \mathrm{~mL})$ & \multicolumn{4}{|c|}{$7,0 \times 10^{5}$} \\
\hline Colifagos (UFP/100 mL) & \multicolumn{4}{|c|}{$1,75 \times 10^{6}$} \\
\hline C. perfringens $((\mathrm{NMP} / 100 \mathrm{~mL})$ & \multicolumn{4}{|c|}{$1,6 \times 10^{7}$} \\
\hline & \multicolumn{4}{|c|}{ Ozônio aplicado: $2,0 \mathrm{mg} / \mathrm{L}$} \\
\hline & \multicolumn{4}{|c|}{ Tempo de contato $(\mathrm{min})$} \\
\hline Parâmetros & 5,0 & 10,0 & 15,0 & 20,0 \\
\hline $\mathrm{pH}$ & 7,7 & 7,1 & 8,3 & 7,3 \\
\hline Alcalinidade $\left(\mathrm{mg} / \mathrm{LcaCO}_{3}\right)$ & 13,72 & 119,76 & 159,68 & 123,75 \\
\hline Temperatura $\left({ }^{\circ} \mathrm{C}\right)$ & 22 & 22 & 22 & 22 \\
\hline Abs (254 nm) & 0,101 & 0,181 & 0,147 & 0,142 \\
\hline $\mathrm{COT}(\mathrm{mg} / \mathrm{L})$ & 45,98 & 45,38 & 42,45 & 37,28 \\
\hline Ozônio residual & 0,97 & 0,98 & 0,95 & 0,91 \\
\hline E. coli (UFC/ $100 \mathrm{~mL})$ & $3 \times 10^{3}$ & 60 & 30 & 10 \\
\hline Colifagos (UFP/100 mL) & $1 \times 10^{3}$ & 900 & 400 & 100 \\
\hline C. perfringens $((\mathrm{NMP} / 100 \mathrm{~mL})$ & $1,6 \times 10^{6}$ & $1,6 \times 10^{6}$ & $1,6 \times 10^{6}$ & $1,6 \times 10^{6}$ \\
\hline
\end{tabular}


TABELA A 23 - Características da água de estudo bruta (cor elevada) e das amostras após a desinfecção com ozônio aplicado em concentração 3,0 mg/L.

\begin{tabular}{|c|c|c|c|c|}
\hline Parâmetros & \multicolumn{4}{|c|}{ Água de estudo } \\
\hline $\mathrm{pH}$ & \multicolumn{4}{|c|}{7,0} \\
\hline Alcalinidade $\left(\mathrm{mg} / \mathrm{L} \mathrm{CaCO}_{3}\right)$ & \multicolumn{4}{|c|}{87,82} \\
\hline Temperatura $\left({ }^{\circ} \mathrm{C}\right)$ & \multicolumn{4}{|c|}{22} \\
\hline Abs (254 nm) & \multicolumn{4}{|c|}{0,047} \\
\hline $\mathrm{COT}(\mathrm{mg} / \mathrm{L})$ & \multicolumn{4}{|c|}{24,40} \\
\hline Cor verdadeira $(\mathrm{uH})$ & \multicolumn{4}{|c|}{177} \\
\hline Turbidez (uT) & \multicolumn{4}{|c|}{0,16} \\
\hline E. coli $(U F C / 100 \mathrm{~mL})$ & \multicolumn{4}{|c|}{$3 \times 10^{4}$} \\
\hline Colifagos (UFP/100 mL) & \multicolumn{4}{|c|}{$2,7 \times 10^{6}$} \\
\hline C. perfringens $((\mathrm{NMP} / 100 \mathrm{~mL})$ & \multicolumn{4}{|c|}{$1,6 \times 10^{7}$} \\
\hline & \multicolumn{4}{|c|}{ Ozônio aplicado: 3,0 mg/L } \\
\hline & \multicolumn{4}{|c|}{ Tempo de contato (min) } \\
\hline Parâmetros & $\mathbf{5 , 0}$ & 10,0 & 15,0 & 20,0 \\
\hline $\mathrm{pH}$ & 7,2 & 7,3 & 7,2 & 7,2 \\
\hline Alcalinidade $\left(\mathrm{mg} / \mathrm{LcaCO}_{3}\right)$ & 91,82 & 99,80 & 83,83 & 83,83 \\
\hline Temperatura $\left({ }^{\circ} \mathrm{C}\right)$ & 22 & 22 & 22 & 22 \\
\hline $\operatorname{Abs}(254 \mathrm{~nm})$ & 0,096 & 0,114 & 0,101 & 0,091 \\
\hline $\operatorname{COT}(\mathrm{mg} / \mathrm{L})$ & 49,3 & 37,41 & 37,02 & 31,67 \\
\hline Ozônio residual & 0,98 & 0,98 & 0,96 & 0,96 \\
\hline E. coli $(U F C / 100 \mathrm{~mL})$ & $1,2 \times 10^{3}$ & 400 & 200 & 100 \\
\hline Colifagos (UFP/100 mL) & $1,89 \times 10^{4}$ & $1,8 \times 10^{4}$ & 140 & 200 \\
\hline C. perfringens $((\mathrm{NMP} / 100 \mathrm{~mL})$ & $1,6 \times 10^{6}$ & $1,6 \times 10^{6}$ & $1,6 \times 10^{6}$ & $1,3 \times 10^{4}$ \\
\hline
\end{tabular}

TABELA A 24 - Características da água de estudo bruta (cor elevada) e das amostras após a desinfecção com ozônio aplicado em concentração 4,0 mg/L.

\begin{tabular}{|c|c|c|c|c|}
\hline Parâmetros & \multicolumn{4}{|c|}{ Água de estudo } \\
\hline $\mathrm{pH}$ & \multicolumn{4}{|c|}{7,2} \\
\hline Alcalinidade $\left(\mathrm{mg} / \mathrm{L} \mathrm{CaCO}_{3}\right)$ & \multicolumn{4}{|c|}{135,73} \\
\hline Temperatura $\left({ }^{\circ} \mathrm{C}\right)$ & \multicolumn{4}{|c|}{22} \\
\hline Abs $(254 \mathrm{~nm})$ & \multicolumn{4}{|c|}{0,245} \\
\hline $\mathrm{COT}(\mathrm{mg} / \mathrm{L})$ & \multicolumn{4}{|c|}{31,71} \\
\hline Cor verdadeira $(\mathrm{uH})$ & \multicolumn{4}{|c|}{197} \\
\hline Turbidez (uT) & \multicolumn{4}{|c|}{0,13} \\
\hline E. coli $(U F C / 100 \mathrm{~mL})$ & \multicolumn{4}{|c|}{$1 \times 10^{6}$} \\
\hline Colifagos (UFP/100 mL) & \multicolumn{4}{|c|}{$1 \times 10^{6}$} \\
\hline C. perfringens $((\mathrm{NMP} / 100 \mathrm{~mL})$ & \multicolumn{4}{|c|}{$5 \times 10^{7}$} \\
\hline & \multicolumn{4}{|c|}{ Ozônio aplicado: $4,0 \mathrm{mg} / \mathrm{L}$} \\
\hline & \multicolumn{4}{|c|}{ Tempo de contato (min) } \\
\hline Parâmetros & 5,0 & 10,0 & 15,0 & 20,0 \\
\hline $\mathrm{pH}$ & 7,5 & 7,0 & 7,5 & 7,5 \\
\hline Alcalinidade $\left(\mathrm{mg} / \mathrm{LcaCO}_{3}\right)$ & 144 & 75,85 & 135,73 & 107,78 \\
\hline Temperatura $\left({ }^{\circ} \mathrm{C}\right)$ & 22 & 22 & 22 & 22 \\
\hline Abs (254 nm) & 0,304 & 0,305 & 0,290 & 0,293 \\
\hline $\mathrm{COT}(\mathrm{mg} / \mathrm{L})$ & 33,53 & 35,05 & 25,73 & 29,88 \\
\hline Ozônio residual & 0,94 & 0,96 & 0,98 & 0,88 \\
\hline E. coli (UFC/ $100 \mathrm{~mL})$ & $1,5 \times 10^{3}$ & $1,5 \times 10^{3}$ & $1,1 \times 10^{3}$ & 700 \\
\hline Colifagos (UFP/100 mL) & $1,5 \times 10^{4}$ & $1,3 \times 10^{4}$ & 600 & 200 \\
\hline C. perfringens $((\mathrm{NMP} / 100 \mathrm{~mL})$ & $2,8 \times 10^{6}$ & $1,6 \times 10^{6}$ & $1,6 \times 10^{6}$ & $1,6 \times 10^{6}$ \\
\hline
\end{tabular}


TABELA A 25 - Características da água de estudo bruta (cor elevada) e das amostras após a desinfecção com ozônio aplicado em concentração 5,0 mg/L.

\begin{tabular}{|c|c|c|c|c|}
\hline Parâmetros & \multicolumn{4}{|c|}{ Água de estudo } \\
\hline $\mathrm{pH}$ & \multicolumn{4}{|c|}{7,4} \\
\hline Alcalinidade $\left(\mathrm{mg} / \mathrm{L} \mathrm{CaCO}_{3}\right)$ & \multicolumn{4}{|c|}{115,7} \\
\hline Temperatura $\left({ }^{\circ} \mathrm{C}\right)$ & \multicolumn{4}{|c|}{22} \\
\hline $\operatorname{Abs}(254 \mathrm{~nm})$ & \multicolumn{4}{|c|}{0,065} \\
\hline $\mathrm{COT}(\mathrm{mg} / \mathrm{L})$ & \multicolumn{4}{|c|}{41,48} \\
\hline Cor verdadeira $(\mathrm{uH})$ & \multicolumn{4}{|c|}{180} \\
\hline Turbidez (uT) & \multicolumn{4}{|c|}{0,2} \\
\hline E. coli (UFC/ $100 \mathrm{~mL})$ & \multicolumn{4}{|c|}{$1 \times 10^{5}$} \\
\hline Colifagos (UFP/100 mL) & \multicolumn{4}{|c|}{$6 \times 10^{5}$} \\
\hline C. perfringens $((\mathrm{NMP} / 100 \mathrm{~mL})$ & \multicolumn{4}{|c|}{$1,6 \times 10^{7}$} \\
\hline & \multicolumn{4}{|c|}{ Ozônio aplicado: $5,0 \mathrm{mg} / \mathrm{L}$} \\
\hline & \multicolumn{4}{|c|}{ Tempo de contato (min) } \\
\hline Parâmetros & 5,0 & 10,0 & 15,0 & 20,0 \\
\hline $\mathrm{pH}$ & 7,6 & 7,3 & 7,6 & 7,7 \\
\hline Alcalinidade $\left(\mathrm{mg} / \mathrm{LcaCO}_{3}\right)$ & 99,8 & 99,8 & 107,8 & 115,7 \\
\hline Temperatura $\left({ }^{\circ} \mathrm{C}\right)$ & 22 & 22 & 22 & 22 \\
\hline Abs (254 nm) & 0,101 & 0,115 & 0,124 & 0,103 \\
\hline $\mathrm{COT}(\mathrm{mg} / \mathrm{L})$ & 41,64 & 43,03 & 42,74 & 42,81 \\
\hline Ozônio residual & 1,01 & 1,02 & 0,98 & 0,96 \\
\hline E. coli (UFC/ $100 \mathrm{~mL})$ & 100 & 200 & 700 & 100 \\
\hline Colifagos (UFP/100 mL) & 500 & 500 & 50 & 50 \\
\hline C. perfringens $((\mathrm{NMP} / 100 \mathrm{~mL})$ & $1,6 \times 10^{5}$ & $1,6 \times 10^{5}$ & $1,6 \times 10^{5}$ & $1,6 \times 10^{5}$ \\
\hline
\end{tabular}

TABELA A 26 - Número final $(\mathrm{N})$ de $E$. coli para o processo combinado $\mathrm{O}_{3} / \mathrm{Cl}_{2}$. $\mathrm{O}$ número inicial de $E$. coli foi de $\mathrm{No}=1,0 \times 10^{8} \mathrm{UFC} / 100 \mathrm{~mL}$.

\begin{tabular}{|c|c|c|c|c|c|c|c|c|c|}
\hline \multicolumn{4}{|c|}{$\begin{array}{c}\text { Desinfetante primário: } \mathrm{O}_{3} \\
\mathrm{~N} \text { de } E \text {. coli para as dosagens aplicadas } \\
(\mathrm{mg} / \mathrm{L})\end{array}$} & \multicolumn{2}{|c|}{$\begin{array}{c}\text { Desinfetante } \\
\text { secundário: } \mathrm{Cl}_{2} \\
\mathrm{~N} \text { de } E \text {. coli para as } \\
\text { dosagens aplicadas } \\
(\mathrm{mg} / \mathrm{L})\end{array}$} & \multicolumn{4}{|c|}{$\begin{array}{c}\text { Processo combinado: } \mathrm{O}_{3} / \mathrm{Cl}_{2} \\
\mathrm{~N} \text { de } E \text {. coli para as combinações indicadas }(\mathrm{mg} / \mathrm{L})\end{array}$} \\
\hline $\begin{array}{l}\text { Tempo } \\
(\min )\end{array}$ & 2,0 & 3,0 & 5,0 & 2,0 & 5,0 & $\begin{array}{l}\mathrm{O}_{3}: 2,0 / \\
\mathrm{Cl}_{2}: 2,0\end{array}$ & $\begin{array}{l}\mathrm{O}_{3}: 3,0 / \\
\mathrm{Cl}_{2}: 2,0\end{array}$ & $\begin{array}{l}\mathrm{O}_{3}: 5,0 / \\
\mathrm{Cl}_{2}: 2,0\end{array}$ & $\begin{array}{l}\mathrm{O}_{3}: 2,0 / \\
\mathrm{Cl}_{2}: 5,0\end{array}$ \\
\hline 5 & $4,78 \times 10^{6}$ & $7,59 \times 10^{5}$ & $1,45 \times 10^{5}$ & $1,00 \times 10^{6}$ & $2,50 \times 10^{5}$ & $2,00 \times 10^{2}$ & $1,90 \times 10^{2}$ & 20,89 & 288,4 \\
\hline 10 & $2,88 \times 10^{6}$ & $6,17 \times 10^{5}$ & $1,09 \times 10^{5}$ & $1,00 \times 10^{6}$ & $2,00 \times 10^{5}$ & 95,49 & 19,05 & 10,47 & 38,02 \\
\hline 15 & $1,12 \times 10^{6}$ & $3,02 \times 10^{5}$ & $7,94 \times 10^{4}$ & $7,90 \times 10^{5}$ & $5,00 \times 10^{4}$ & 10,96 & 14,13 & 9,55 & 2,88 \\
\hline 20 & $7,90 \times 10^{5}$ & $1,99 \times 10^{5}$ & $6,03 \times 10^{4}$ & $5,00 \times 10^{5}$ & $3,20 \times 10^{4}$ & 9,55 & 10,96 & 1,91 & 1,74 \\
\hline
\end{tabular}


TABELA A 27 - Número final $(\mathrm{N})$ de colifagos para o processo combinado $\mathrm{O}_{3} / \mathrm{Cl}_{2} \mathrm{O}$ número inicial de colifagos foi de $\mathrm{No}=2,0 \times 10^{7} \mathrm{UFP} / 100 \mathrm{~mL}$.

\begin{tabular}{|c|c|c|c|c|c|c|c|c|c|}
\hline \multicolumn{4}{|c|}{$\begin{array}{c}\text { Desinfetante primário: } \mathrm{O}_{3} \\
\mathrm{~N} \text { de colifagos para as dosagens aplicadas } \\
(\mathrm{mg} / \mathrm{L})\end{array}$} & \multicolumn{2}{|c|}{$\begin{array}{c}\text { Desinfetante } \\
\text { secundário: } \mathrm{Cl}_{2} \\
\mathrm{~N} \text { de colifagos para } \\
\text { as dosagens } \\
\text { aplicadas }(\mathrm{mg} / \mathrm{L})\end{array}$} & \multicolumn{4}{|c|}{$\begin{array}{c}\text { Processo combinado: } \mathrm{O}_{3} / \mathrm{Cl}_{2} \\
\mathrm{~N} \text { de colifagos para as combinações indicadas }(\mathrm{mg} / \mathrm{L})\end{array}$} \\
\hline $\begin{array}{l}\text { Tempo } \\
(\min )\end{array}$ & 2,0 & 3,0 & 5,0 & 2,0 & 5,0 & $\begin{array}{l}\mathrm{O}_{3}: 2,0 / \\
\mathrm{Cl}_{2}: 2,0\end{array}$ & $\begin{array}{l}\mathrm{O}_{3}: 3,0 / \\
\mathrm{Cl}_{2}: 2,0\end{array}$ & $\begin{array}{l}\mathrm{O}_{3}: 5,0 / \\
\mathrm{Cl}_{2}: 2,0\end{array}$ & $\begin{array}{l}\mathrm{O}_{3}: 2,0 / \\
\mathrm{Cl}_{2}: 5,0\end{array}$ \\
\hline 5 & $9,80 \times 10^{4}$ & $1,63 \times 10^{4}$ & $4,58 \times 10^{3}$ & $2,00 \times 10^{6}$ & $1,00 \times 10^{5}$ & $1,74 \times 10^{2}$ & 115,1 & 38,11 & 19,10 \\
\hline 10 & $9,57 \times 10^{4}$ & $1,21 \times 10^{4}$ & $3,99 \times 10^{3}$ & $2,00 \times 10^{6}$ & $6,62 \times 10^{4}$ & 39,91 & 41,79 & 19,10 & 11,51 \\
\hline 15 & $8,53 \times 10^{4}$ & $1,03 \times 10^{4}$ & $2,83 \times 10^{3}$ & $1,00 \times 10^{6}$ & $1,52 \times 10^{4}$ & 3,99 & 10,74 & 2,09 & 10,74 \\
\hline 20 & $2,00 \times 10^{4}$ & $6,04 \times 10^{3}$ & $1,59 \times 10^{3}$ & $3,02 \times 10^{5}$ & $1,21 \times 10^{4}$ & 2,09 & 6,62 & 1,91 & 2,19 \\
\hline
\end{tabular}

TABELA A 28 - Número final (N) de C. perfringens de para o processo combinado $\mathrm{O}_{3} / \mathrm{Cl}_{2}$. O número inicial de $C$. perfringens foi de $\mathrm{No}=1,0 \times 10^{7} \mathrm{NMP} / 100 \mathrm{~mL}$.

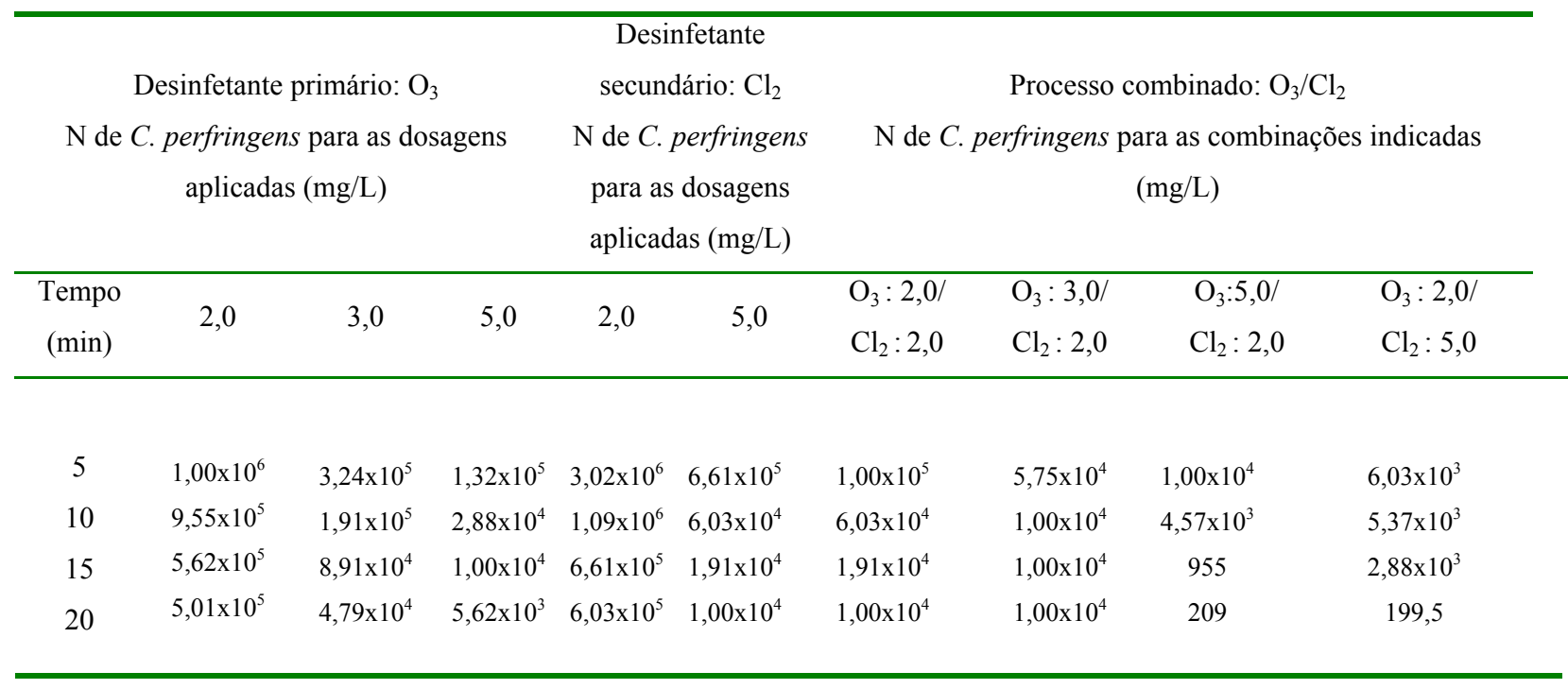

